National Water Availability and Use Pilot Program

\title{
Estimation of Groundwater Use for a Groundwater-Flow Model of the Lake Michigan Basin and Adjacent Areas, 1864-2005
}

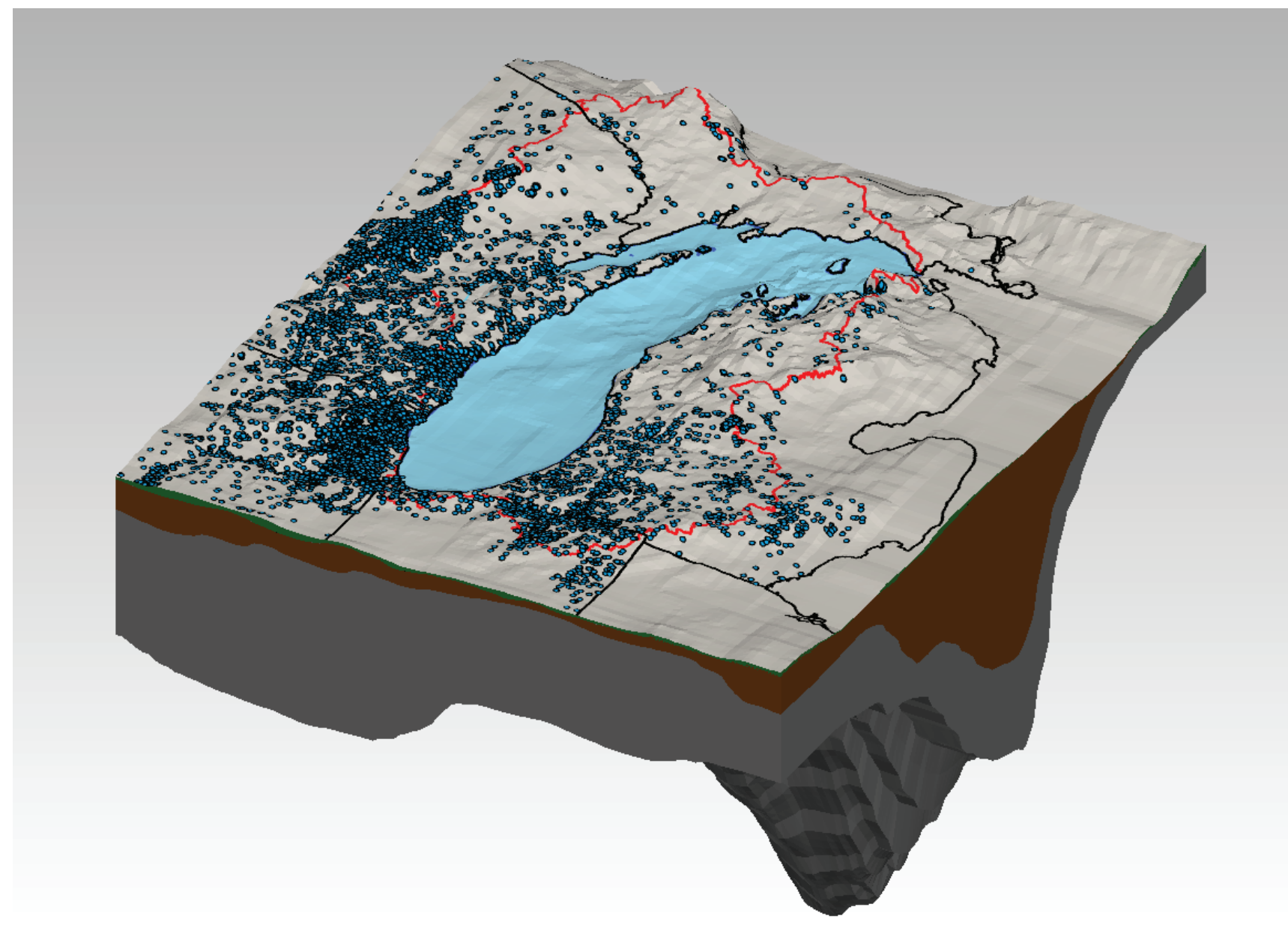

Scientific Investigations Report 2010-5068 
Cover image: Three-dimensional rendering of significant groundwater-withdrawal points within and near Lake Michigan Basin and aquifer systems beneath the basin. (Image by David Lampe, U.S. Geological Survey.) 


\section{Estimation of Groundwater Use for a Ground water-Flow Model of the Lake Michigan Basin and Adjacent Areas, 1864-2005}

By Cheryl A. Buchwald, Carol L. Luukkonen, and Cynthia M. Rachol

National Water Availability and Use Pilot Program

Scientific Investigations Report 2010-5068 


\title{
U.S. Department of the Interior \\ KEN SALAZAR, Secretary \\ U.S. Geological Survey \\ Marcia K. McNutt, Director
}

\section{U.S. Geological Survey, Reston, Virginia: 2010}

\author{
For more information on the USGS — the Federal source for science about the Earth, its natural and living resources, \\ natural hazards, and the environment, visit http://www.usgs.gov or call 1-888-ASK-USGS \\ For an overview of USGS information products, including maps, imagery, and publications, \\ visit http://www.usgs.gov/pubprod \\ To order this and other USGS information products, visit http://store.usgs.gov
}

\begin{abstract}
Any use of trade, product, or firm names is for descriptive purposes only and does not imply endorsement by the U.S. Government.

Although this report is in the public domain, permission must be secured from the individual copyright owners to reproduce any copyrighted materials contained within this report.
\end{abstract}

Suggested citation:

Buchwald, C.A., Luukkonen, C.L., and Rachol, C.M., 2010, Estimation of groundwater use for a groundwater-flow model of the Lake Michigan Basin and adjacent areas, 1864-2005: U.S. Geological Survey Scientific Investigations Report 2010-5068, 120 p. 


\section{Acknowledgments}

The authors gratefully acknowledge the assistance of the many water facility operators who supplied data for this report. Ralph Spaeth, Indiana Department of Natural Resources, Andrew LeBaron, Michigan Department of Natural Resources, and Ron Van Til (formerly with the Michigan Department of Natural Resources) also furnished much water-use data. The authors also wish to thank Madeline Gotkowitz, Wisconsin Geological and Natural History Survey, for her thorough technical review of appendix 6 and Steve Miller, Michigan State University Department of Agricultural Engineering, for his assistance with the irrigation scheduling program. Also thanked are Robert Biebel and Katherine Madison of Southeastern Wisconsin Regional Planning Commission for responding to inquiries and exchanging data for water-supply forecasts, and Audra Hubbell for generously arranging access to census archives for Wisconsin irrigation data. Timothy Anderson, Region 2 Planning Commission; David Bee, West Michigan Shoreline Regional Development Commission; Jon Coleman, Tri-County Regional Planning Commission; Richard Deuell, Northeast Michigan Council of Governments; Jeff Hagan, Eastern Upper Peninsula Regional Planning and Development Commission; and Kathy TenWolde, East Central Michigan Planning and Development Regional Commission also supplied information for regional water-supply forecasts.

The authors acknowledge Kimberly Shaffer, U.S. Geological Survey (USGS) Ohio Water Science Center, and Donald Arvin, USGS Indiana Water Science Center, for their thorough technical reviews of the draft report. Daniel Feinstein, USGS Wisconsin Water Science Center, and Howard Reeves, USGS Michigan Water Science Center, assisted with data interpretation and clarified modeling details. Lori Fuller, USGS Michigan Water Science Center, analyzed aerial photos and delineated agricultural areas. T. Adam Gallagher and Austin Baldwin, USGS Wisconsin Water Science Center, provided valued assistance in compiling records for the Wisconsin historical water-use dataset. Additional thanks are extended to Michael Eberle and Bonnie S. Fink for their thorough editorial reviews of the text, tables, and figures. 



\section{Contents}

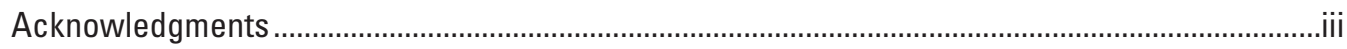

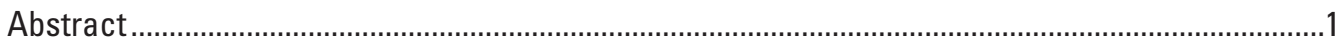

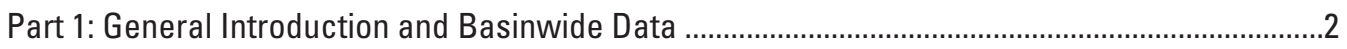

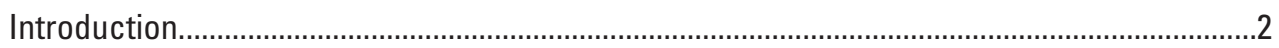

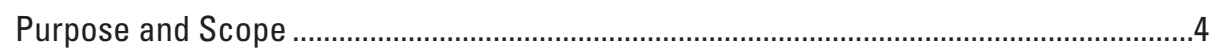

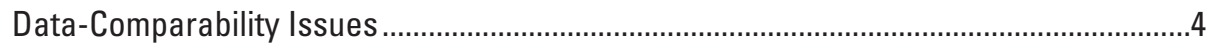

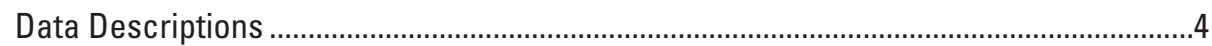

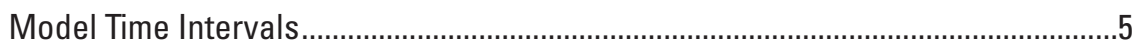

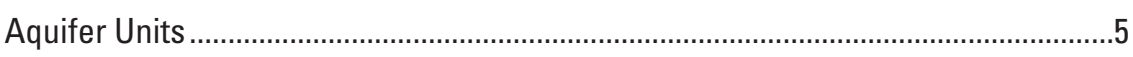

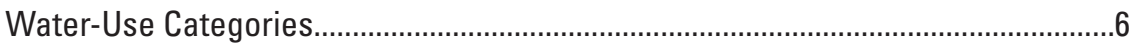

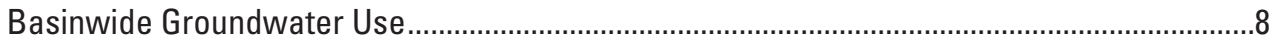

Part 2: State-by-State Descriptions of Water-Use Estimates.........................................................20

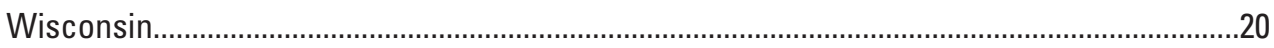

History of Groundwater Management and Water-Use Data Collection in

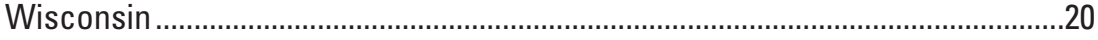

Overview of Wisconsin Data From the Lake Michigan Basin Study..............................21

Principal Wisconsin Data Sources ...................................................................................23

Public-Supply Water Use in Wisconsin .........................................................................24

Additional Wisconsin Public-Supply Data Sources................................................26

Estimation Methods for Wisconsin Public-Supply Withdrawals..............................26

Assumptions and Limitations of Wisconsin Public-Supply Data .............................28

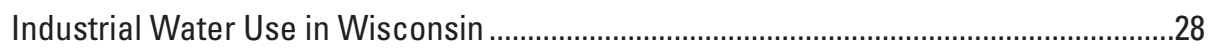

Additional Wisconsin Industrial Data Sources.....................................................29

Estimation Methods for Wisconsin Industrial and Commercial Withdrawals .......31

Assumptions and Limitations of Wisconsin Industrial and Commercial Data........35

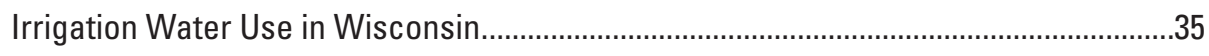

Additional Wisconsin Irrigation Data Sources .....................................................36

Estimation Methods for Wisconsin Irrigation Withdrawals .....................................36

Assumptions and Limitations of Wisconsin Irrigation Data .....................................39

Miscellaneous Water Use in Wisconsin......................................................................40

Additional Wisconsin Miscellaneous Data Sources ...............................................40

Estimation Methods for Wisconsin Aquaculture Withdrawals ...............................40

Estimation Methods for Wisconsin Thermoelectric Power Withdrawals ..............40

Assumptions and Limitations for Wisconsin Miscellaneous Data ............................42

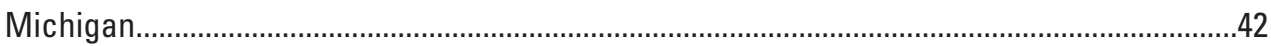

History of Groundwater Management and Water-Use Data Collection in Michigan ....42

Overview of Michigan Data From the Lake Michigan Basin Study...............................42

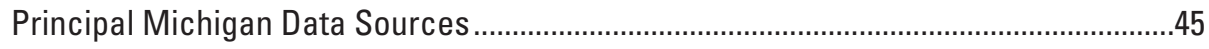

Public-Supply Water Use in Michigan .....................................................................46

Additional Michigan Public-Supply Data Sources.................................................49

Estimation Methods for Michigan Public-Supply Withdrawals...............................49

Assumptions and Limitations of Michigan Public-Supply Data ...............................50 
Part 2: State-by-State Descriptions of Water-Use Estimates, Michigan—Continued

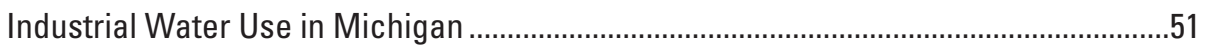

Additional Michigan Industrial Data Sources.....................................................53

Estimation Methods for Michigan Industrial Withdrawals.......................................53

Assumptions and Limitations of Michigan Industrial Data .......................................53

Irrigation Water Use in Michigan...............................................................................54

Additional Michigan Irrigation Data Sources ....................................................54

Estimation Methods for Michigan Agricultural Irrigation Withdrawals ..................57

Estimation Methods for Michigan Golf Course Irrigation Withdrawals ..................59

Assumptions and Limitations of Michigan Irrigation Data .....................................60

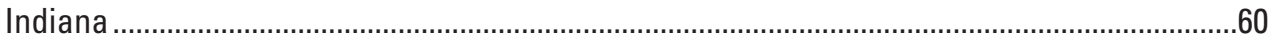

History of Groundwater Management and Water-Use Data Collection in Indiana ........60

Overview of Indiana Data From the Lake Michigan Basin Study ....................................61

Principal Indiana Data Sources .................................................................................61

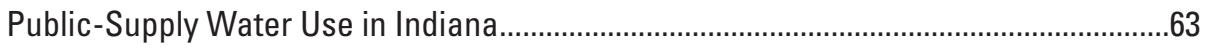

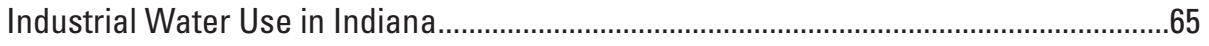

Irrigation Water Use in Indiana ............................................................................66

Assumptions and Limitations of Indiana Public-Supply, Industrial, and Irrigation

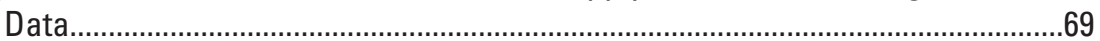

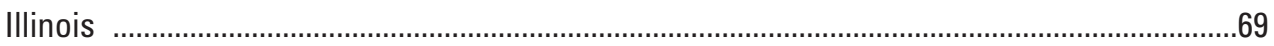

History of Groundwater Management and Water-Use Data Collection in Illinois..........69

Overview of Illinois Data From the Lake Michigan Basin Study .....................................70

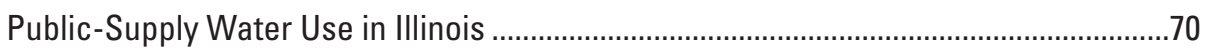

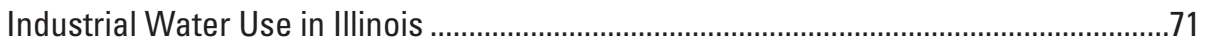

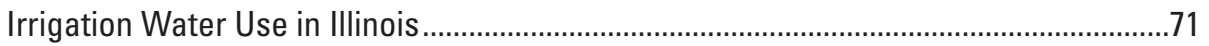

Assumptions and Limitations of Illinois Public-Supply, Industrial, and Irrigation

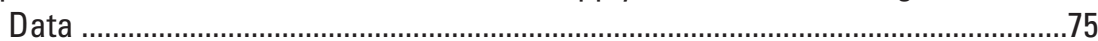

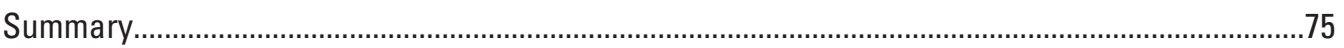

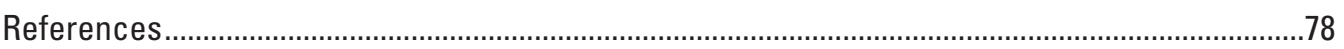

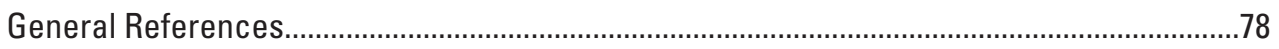

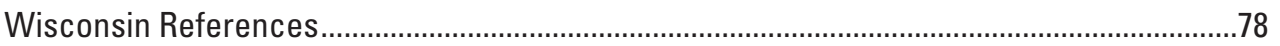

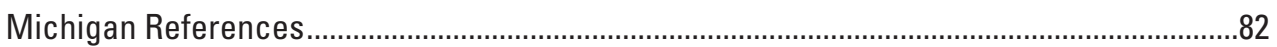

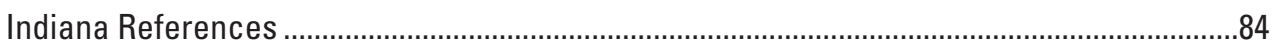

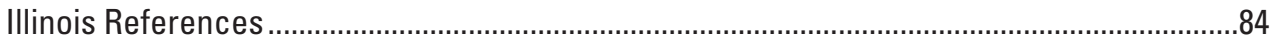

Glossary

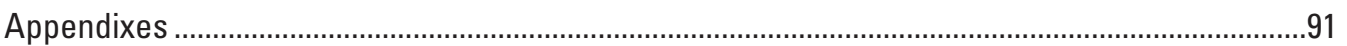

1. Stratigraphic columns for Wisconsin, Illinois, Indiana, Ohio, and Michigan and assigned hydrogeologic-unit model layers and aquifer systems......................................92

2-5. State water-use category estimates for the Lake Michigan Basin model by time interval and $A$, model subregion; $B$, aquifer system; and $C$, aquifer type:

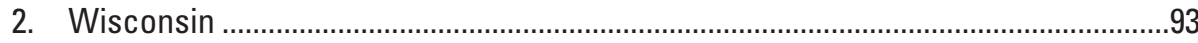

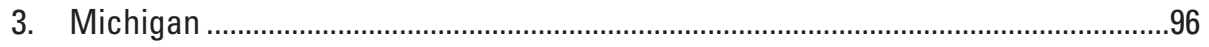

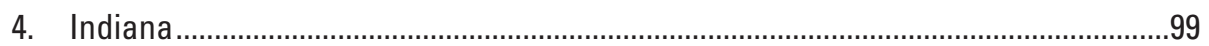

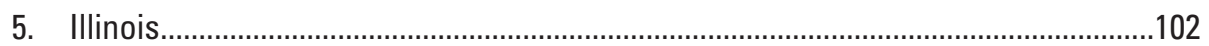


Appendixes-Continued

6. Water-use estimates for 2040:

A. Estimation methods for 2040 water use 105

B. Lake Michigan Basin model time interval 12 (2001-5) and 2040 groundwateruse estimates by category, model subregion, and aquifer system ........................111

C. Methods for estimating 2040 water use by category and state ............................113

D. References used in the estimation of 2040 water use, by state .............................115

E. Adjusted model rates and estimated percent change in employment for Wisconsin industrial water-use projections for the year 2040

\section{Figures}

1. Map showing Lake Michigan Basin model boundaries and subregions ...........................3

2. Graphs showing groundwater-use estimates by state and by water-use category for the Lake Michigan Basin model area, 1864-2005

3. Map showing Wisconsin and Illinois model areas of the Lake Michigan Basin model

4-6. Graphs showing-

4. Public-supply groundwater-use estimates in Wisconsin for the Lake Michigan Basin model by time interval and model subregion, aquifer system, and aquifer type

5. Public-supply per capita water use in the nearfield model area of Wisconsin, 1971-2005

6. Industrial groundwater-use estimates in Wisconsin for the Lake Michigan Basin model by time interval and model subregion, aquifer system, and aquifer type.

7. Flow chart showing the approach and methods applied for estimating industrial and commercial groundwater withdrawals in Wisconsin.

8. Graphs showing irrigation groundwater-use estimates in Wisconsin for the Lake Michigan Basin model by time interval and model subregion, aquifer system, and aquifer type.

9. Graphs showing miscellaneous groundwater-use estimates in Wisconsin for the Lake Michigan Basin model by time interval and model subregion, aquifer system, and aquifer type

10. Map showing Michigan and Indiana model areas of the Lake Michigan Basin model

11. Maps showing Michigan counties for which groundwater-use estimates were made for the Lake Michigan Basin model, by category

12-26. Graphs showing -

12. Population and number of communities in Michigan counties in the Lake Michigan Basin area

13. Michigan groundwater-use estimates for the Lake Michigan Basin model by time interval and category.

14. Public-supply groundwater-use estimates in Michigan for the Lake Michigan Basin model by time interval and model subregion, aquifer system, and aquifer type

15. Public-supply per capita water use in the nearfield model area of Michigan, 1869-2004 
16. Industrial groundwater-use estimates in Michigan for the Lake Michigan Basin model by time interval and model subregion, aquifer system, and aquifer type.

17. Irrigation groundwater-use estimates in Michigan for the Lake Michigan Basin model by time interval and model subregion, aquifer system, and aquifer type.

18. Population and number of communities in Northern Indiana counties in the Lake Michigan Basin area

19. Indiana groundwater-use estimates for the Lake Michigan Basin model by time interval and category.

20. Public-supply groundwater-use estimates in Indiana for the Lake Michigan Basin model by time interval and model subregion, aquifer system, and aquifer type.

21. Public-supply per capita water use in the nearfield model area of Indiana, 1980-2000

22. Industrial groundwater-use estimates in Indiana for the Lake Michigan Basin model by time interval and model subregion, aquifer system, and aquifer type.

23. Irrigation groundwater-use estimates in Indiana for the Lake Michigan Basin model by time interval and model subregion, aquifer system, and aquifer type.

24. Public-supply groundwater-use estimates in Illinois for the Lake Michigan Basin model by time interval and model subregion, aquifer system, and aquifer type.

25. Industrial groundwater-use estimates in Illinois for the Lake Michigan Basin model by time interval and model subregion, aquifer system, and aquifer type.

26. Irrigation groundwater-use estimates in Illinois for the Lake Michigan Basin model by time interval and model subregion, aquifer system, and aquifer type.

\section{Tables}

1. Description and comparison of U.S. Geological Survey or State-specific and report-specific water-use categories, by state.

2. Lake Michigan Basin model estimated groundwater withdrawals by state and model area, 1864-2005

3. Lake Michigan Basin model estimated groundwater withdrawals by model subregion, 1864-2005

4. Lake Michigan Basin model estimated groundwater withdrawals by state and water-use category, 1864-2005

5. Lake Michigan Basin model estimated groundwater withdrawals by state and aquifer system, 1864-2005.

6. Lake Michigan Basin model estimated groundwater withdrawals by state and model layer, 1864-2005

7. Lake Michigan Basin model estimated groundwater withdrawals by state and aquifer type, 1864-2005

8. Groundwater-withdrawal estimation methods for industrial water use in Wisconsin, by water-use purpose 
9. Irrigation default groundwater-use values used in Wisconsin, by purpose

10. Estimated amount of groundwater withdrawn for industrial use in part of Michigan that is released to recharge the groundwater system

11. Emergence dates and length of growing season used in the irrigation scheduling program

12. Effective rooting depth, by crop, provided as defaults used in the irrigationscheduling program

13. Maximum allowable depletion, by crop type

14. Default values for the available soil moisture for various soils used in the irrigation-scheduling program

15. County and climate-observation station name and time period of temperature and precipitation data used in the irrigation-scheduling program

16. Irrigation-estimate and aerial-photograph years matched to each model time interval.

\section{Conversion Factors and Abbreviations}

\begin{tabular}{|c|c|c|}
\hline Multiply & By & To Obtain \\
\hline \multicolumn{3}{|c|}{ Length } \\
\hline inch (in.) & 2.54 & centimeter $(\mathrm{cm})$ \\
\hline foot $(\mathrm{ft})$ & 0.3048 & meter $(\mathrm{m})$ \\
\hline mile (mi) & 1.609 & kilometer $(\mathrm{km})$ \\
\hline \multicolumn{3}{|c|}{ Area } \\
\hline acre & 0.004047 & square kilometer $\left(\mathrm{km}^{2}\right)$ \\
\hline acre & 0.001562 & square mile $\left(\mathrm{mi}^{2}\right)$ \\
\hline acre & 43,560 & square foot $\left(\mathrm{ft}^{2}\right)$ \\
\hline square mile $\left(\mathrm{mi}^{2}\right)$ & 2.590 & square kilometer $\left(\mathrm{km}^{2}\right)$ \\
\hline \multicolumn{3}{|c|}{ Volume } \\
\hline gallon (gal) & 3.785 & liter $(\mathrm{L})$ \\
\hline gallon (gal) & 0.003785 & cubic meter $\left(\mathrm{m}^{3}\right)$ \\
\hline million gallons (Mgal) & 3,785 & cubic meter $\left(\mathrm{m}^{3}\right)$ \\
\hline acre-foot (acre-ft) & 3,258 & gallon (gal) \\
\hline acre-foot (acre-ft) & 1,233 & cubic meter $\left(\mathrm{m}^{3}\right)$ \\
\hline \multicolumn{3}{|c|}{ Flow rate } \\
\hline cubic foot per second $\left(\mathrm{ft}^{3} / \mathrm{s}\right)$ & 0.02832 & cubic meter per second $\left(\mathrm{m}^{3} / \mathrm{s}\right)$ \\
\hline gallon per minute (gal/min) & 0.06309 & liter per second $(\mathrm{L} / \mathrm{s})$ \\
\hline gallon per day (gal/d) & 0.003785 & cubic meter per day $\left(\mathrm{m}^{3} / \mathrm{d}\right)$ \\
\hline $\begin{array}{l}\text { gallon per day per acre }[(\mathrm{gal} / \mathrm{d}) / \\
\text { acre }]\end{array}$ & 1.069 & $\begin{array}{l}\text { cubic meter per day per square } \\
\text { kilometer }\left[\left(\mathrm{m}^{3} / \mathrm{d}\right) / \mathrm{km}^{2}\right]\end{array}$ \\
\hline inch per year (in/yr) & 25.4 & millimeter per year $(\mathrm{mm} / \mathrm{yr})$ \\
\hline acre-foot per day (acre-ft/d) & 3,258 & gallon per day (gal/d) \\
\hline million gallons per day (Mgal/d) & 1,337 & cubic foot per day $\left(\mathrm{ft}^{3} / \mathrm{d}\right)$ \\
\hline million gallons per day (Mgal/d) & 0.04381 & cubic meter per second $\left(\mathrm{m}^{3} / \mathrm{s}\right)$ \\
\hline million gallons per year (Mgal/yr) & 0.002738 & million gallons per day (Mgal/d) \\
\hline
\end{tabular}




\section{Acronyms}

\begin{tabular}{ll} 
EWG & Environmental Working Group \\
GIS & Geographic Information System \\
GRN & Groundwater Retrieval Network \\
GWIM & Groundwater Inventory and Mapping \\
GWSI & Groundwater Site Inventory \\
IDNR & Indiana Department of Natural Resources \\
ISWS & Illinois State Water Survey \\
IWIP & Illinois Water Inventory Program \\
LMB & Lake Michigan Basin \\
MDA & Michigan Department of Agriculture \\
MDEO & Michigan Department of Environmental Quality \\
MNDNR & Minnesota Department of Natural Resources \\
MNDNR WAPP & Minnesota Department of Natural Resources Water Appropriations \\
& Permit Program \\
MSU & Michigan State University \\
NAIP & National Agriculture Imagery Program \\
NASS & National Agricultural and Statistics Service \\
PICS & Public Industrial-Commercial Survey \\
PSC & Public Service Commission \\
RASA & Regional Aquifer Systems Analysis \\
SDWIS & Safe Drinking Water Information System \\
SEWRPC & Southeastern Wisconsin Regional Planning Commission \\
SIC & Standard Industrial Classification \\
STATSGO & State Soil Geographic Database \\
SWCD & Soil and Water Conservation District \\
SWUDS & Site-Specific Water-Use Database System \\
SWWF & Significant Water Withdrawal Facility \\
USDA & United States Department of Agriculture \\
USEPA & United States Environmental Protection Agency \\
USGS & United States Geological Survey \\
USGS WI WSC & United States Geological Survey Wisconsin Water Science Center \\
WDNR & Wisconsin Department of Natural Resources \\
WGNHS & Wisconsin Geological and Natural History Survey \\
WI DOA & Wisconsin Department of Administration \\
WUA & Water Use Act \\
& \\
& \\
\hline
\end{tabular}




\title{
Estimation of Groundwater Use for a Groundwater-Flow Model of the Lake Michigan Basin and Adjacent Areas, 1864-2005
}

\author{
By Cheryl A. Buchwald, Carol L. Luukkonen, and Cynthia M. Rachol
}

\section{Abstract}

The U.S. Geological Survey, at the request of Congress, is assessing the availability and use of the Nation's water resources to help characterize how much water is available now, how water availability is changing, and how much water can be expected to be available in the future. The Great Lakes Basin Pilot project of the U.S. Geological Survey national assessment of water availability and use focused on the Great Lakes Basin and included detailed studies of the processes governing water availability in the Great Lakes Basin. One of these studies included the development of a groundwater-flow model of the Lake Michigan Basin. This report describes the compilation and estimation of the groundwater withdrawals in those areas in Wisconsin, Michigan, Indiana, and Illinois that were needed for the Lake Michigan Basin study groundwaterflow model. These data were aggregated for 12 model time intervals spanning 1864 to 2005 and were summarized by model area, model subregion, category of water use, aquifer system, aquifer type, and hydrogeologic unit model layer.

The types and availability of information on groundwater withdrawals vary considerably among states because wateruse programs often differ in the types of data collected and in the methods and frequency of data collection. As a consequence, the methods used to estimate and verify the data also vary. Additionally, because of the different sources of data and different terminologies applied for the purposes of this report, the water-use data published in this report may differ from water-use data presented in other reports. These data represent only a partial estimate of groundwater use in each state because estimates were compiled only for areas in Wisconsin, Michigan, Indiana, and Illinois within the Lake Michigan Basin model area. Groundwater-withdrawal data were compiled for both nearfield and farfield model areas in Wisconsin and Illinois, whereas these data were compiled primarily for the nearfield model area in Michigan and Indiana.

Overall water use for the selected areas in Wisconsin, Michigan, Indiana, and Illinois was less during early time intervals than during more recent intervals, with large increases beginning around the 1960s. Total estimated groundwater withdrawals for model input range from 18.01 million gallons per day (Mgal/d) for interval 1 (1864-1900) to 1,280.25 Mgal/d for interval 12 (2001-5). Withdrawals for the public-supply category make up the majority of the withdrawals in each of the four states. In Wisconsin and Michigan, the second largest withdrawals are for the irrigation category; in Indiana and Illinois, industrial withdrawals account for the second largest withdrawal amounts. The smallest withdrawals are for miscellaneous uses in Wisconsin and irrigation uses in Indiana and Illinois.

Estimated groundwater withdrawals in the Southern Lower Peninsula of Michigan, Northeastern Illinois, and the farfield model area are generally larger than in the other model subregions. Withdrawals in Michigan and Indiana are predominantly from the Quaternary aquifer system, whereas withdrawals in Illinois are predominantly from the CambrianOrdovician aquifer systems. Withdrawals in Wisconsin are about equal from the Quaternary and Cambrian-Ordovician aquifer systems. Estimated groundwater withdrawals in Michigan and Indiana are predominantly from the unconfined unconsolidated aquifer type. Withdrawals in Illinois are largely from the deep confined bedrock aquifer type, although they decreased considerably in more recent time intervals. Wisconsin withdrawals are about equal from unconfined unconsolidated and deep confined bedrock aquifer types.

Groundwater-withdrawal estimates in Wisconsin were compiled for the 47 easternmost counties within the boundary of the Lake Michigan Basin model, of which 32 counties, though not entirely contained, are at least partly within the Lake Michigan Basin. Overall, 6,457 withdrawal locations were estimated in the Wisconsin part of the Lake Michigan Basin model area, and 5,151 locations were active in the last time interval (2001-5) for a total groundwater withdrawal of $476.51 \mathrm{Mgal} / \mathrm{d}$. Total withdrawals for the nearfield model area increased consistently from $1.84 \mathrm{Mgal} / \mathrm{d}$ in time interval 1 (1864-1900) to $192.88 \mathrm{Mgal} / \mathrm{d}$ in interval 12 (2001-5); farfield model area withdrawals increased from $1.35 \mathrm{Mgal} / \mathrm{d}$ in interval 1 to 283.63 $\mathrm{Mgal} / \mathrm{d}$ in interval 12 . Withdrawals by nearfield model subregions for interval 1 to interval 12 increased from $0.82 \mathrm{Mgal} / \mathrm{d}$ to $118.59 \mathrm{Mgal} / \mathrm{d}$ in Northeastern Wisconsin and from $1.02 \mathrm{Mgal} / \mathrm{d}$ to $76.57 \mathrm{Mgal} / \mathrm{d}$ in Southeastern Wisconsin, with the exception of interval 10 (1986-1990). 
Groundwater-withdrawal estimates in Michigan were determined for those counties in Michigan with at least some part within the boundaries of the basin, plus Monroe County. Overall, there were 2,046 withdrawal locations estimated for counties within the Lake Michigan Basin model area, and 1,860 locations were active in the last time interval (2001-5) for a total withdrawal of $397.72 \mathrm{Mgal} / \mathrm{d}$. Estimated withdrawals for the nearfield model area range from $7.43 \mathrm{Mgal} / \mathrm{d}$ in time interval 1 (1864-1900) to $359.91 \mathrm{Mgal} / \mathrm{d}$ in interval 12 (2001-5); farfield model area withdrawals range from 0.63 $\mathrm{Mgal} / \mathrm{d}$ in interval 1 to $37.81 \mathrm{Mgal} / \mathrm{d}$ in interval 12. Estimated withdrawals by nearfield model subregions for interval 1 to interval 12 range from $7.21 \mathrm{Mgal} / \mathrm{d}$ to $306.15 \mathrm{Mgal} / \mathrm{d}$ in the Southern Lower Peninsula, $0.22 \mathrm{Mgal} / \mathrm{d}$ to $44.83 \mathrm{Mgal} / \mathrm{d}$ in the Northern Lower Peninsula, and 0 to $8.94 \mathrm{Mgal} / \mathrm{d}$ in the Upper Peninsula.

Groundwater-withdrawal estimates in Indiana were determined for 11 counties in the Northern Indiana subregion, all of which have at least some part within the Lake Michigan Basin boundary. Overall, a total of 2,002 withdrawal locations were estimated for these counties, and 1,104 locations were active in the last model time interval (2001-5) for a total withdrawal of $128.3 \mathrm{Mgal} / \mathrm{d}$. Total withdrawals in Indiana for the nearfield model area range from $0.21 \mathrm{Mgal} / \mathrm{d}$ in interval 3 (1921-40) to $117.42 \mathrm{Mgal} / \mathrm{d}$ in interval 12 (2001-5), and withdrawals from the farfield model area range from $0 \mathrm{Mgal} / \mathrm{d}$ in interval 3 to $10.88 \mathrm{Mgal} / \mathrm{d}$ for interval 12.

Groundwater-withdrawal estimates in Illinois were determined for three distinct blocks of time (1864-1964, 1964-1979, and 1979-2004) based on how the data were inventoried. The groundwater-withdrawal data from before 1964, corresponding to model time intervals 1 through 5 (1864-1960) and part of interval 6 (1961-1970), were summarized for seven major pumping centers in the nearfield model area (which is also the Northeastern Illinois subregion). Wateruse estimates from 1964 to 2004 were assigned to intervals 6 through 12 (1961-2005) for the 40 counties in the Illinois Lake Michigan Basin model area. In the nearfield model area, withdrawals range from $6.76 \mathrm{Mgal} / \mathrm{d}$ in time interval 1 (1864-1900) to $301.71 \mathrm{Mgal} / \mathrm{d}$ in interval 8 (1976-80), then decrease to $166.93 \mathrm{Mgal} / \mathrm{d}$ in interval 12 (2001-5).

\section{Part 1: General Introduction and Basinwide Data}

\section{Introduction}

The Great Lakes Basin, which encompasses Lakes Superior, Michigan, Huron, Erie, and Ontario, contains 95 percent of the fresh surface water in North America and 18 percent of the fresh surface water in the world. Groundwater ${ }^{1}$ within the Great Lakes Basin constitutes another large volume of freshwater. Yet, even in this water-abundant area, water withdrawals, diversions, and use sometimes conflict with the needs of other users and ecosystems in the basin. Thus, at the request of Congress, the U.S. Geological Survey (USGS) is assessing the availability and use of the Nation's water resources to gain a clearer understanding of the status of the resources and the land-use, water-use, and climatic trends that affect them. This national assessment of water availability and use will help characterize how much water is available now, how water availability is changing, and how much water can be expected to be available in the future (Grannemann and Reeves, 2005). The Great Lakes Basin Pilot project of the USGS national assessment of water availability and use focused on the Great Lakes Basin.

The Great Lakes Basin Pilot project included studies to determine the best methods to evaluate water resources and to develop strategies for delivering information about water availability and use. Evaluation of the effects of groundwater withdrawals also was needed because of lowered water levels. In some areas along Lake Michigan within the Great Lakes Basin, the water table or artesian water level has declined in excess of $40 \mathrm{ft}$ since predevelopment, and freshwater head has declined more than $700 \mathrm{ft}$ in at least one aquifer (Mandle and Kontis, 1992; Reilly and others, 2008). An aquifer is a geologic formation that is sufficiently saturated and permeable to yield considerable quantities of water to wells or springs (Solley and others, 1998). As part of this pilot project, a groundwater-flow model of the Lake Michigan Basin was developed to assess the effect of water withdrawals on groundwater levels, on base flow to streams and lakes, and on the capacity to meet future demand for water. The Lake Michigan Basin includes parts of Wisconsin, Michigan, Indiana, Illinois, and Ohio (fig. 1). The compilation and estimation of water withdrawals needed for input to the Lake Michigan Basin study groundwater-flow model are described in the following sections in this report.

'Bolded terms (or close variants thereof) are defined in the glossary near the end of this report. 


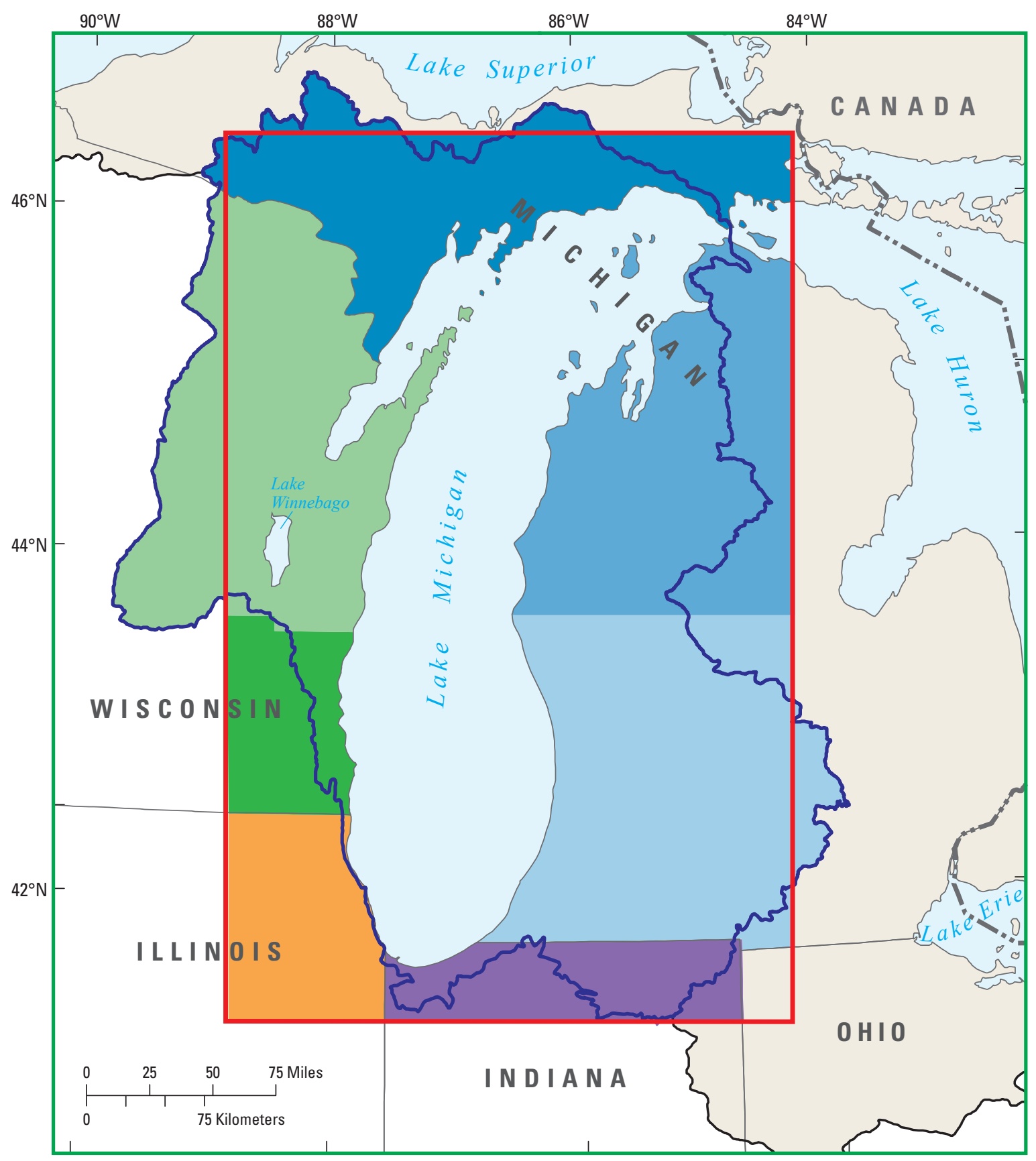

\section{EXPLANATION}

Model subregions

Northeastern Wisconsin
Southeastern Wisconsin
Upper Peninsula of Michigan
Northern Lower Peninsula of Michigan
Southern Lower Peninsula of Michigan
Northern Indiana
Northeastern Illinois

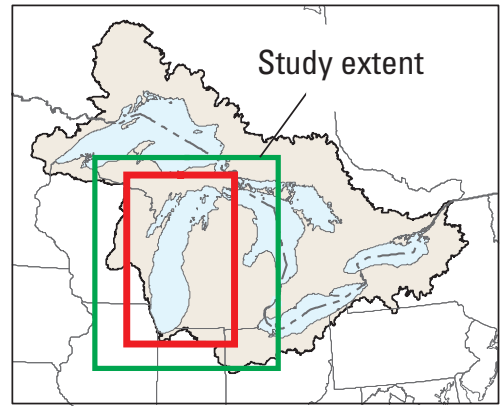

Figure 1. Lake Michigan Basin model boundaries and subregions. 
Estimation of Groundwater Use, Lake Michigan Basin and Adjacent Areas, 1864-2005

\section{Purpose and Scope}

This report describes construction of the water-use datasets and summarizes the groundwater-withdrawal data for Wisconsin, Michigan, Indiana, and Illinois that were used in the Lake Michigan Basin groundwater-flow model (hereafter referred to as "LMB model") (Feinstein and others, in press). The developed water-use datasets served as input needed for the model simulation to assess the effects of hydrologic stress (for example, development) on water resources. Data compiled for these datasets came from interpretive maps, previously published reports, previous USGS model water-use datasets, other agencies, and information from inquiries.

The water-use data represent pumping of mostly highcapacity wells from unconfined unconsolidated and bedrock aquifers or from deep confined bedrock aquifers. Presented in this report are withdrawals estimated for four major wateruse categories: public supply, industrial, irrigation, and miscellaneous.

The availability of information on groundwater withdrawals varies considerably among states because water-use programs often differ in the types of data collected and in the methods and frequency of data collection. As a consequence, the methods described in this report to estimate and verify the data for each state also vary. Detailed descriptions of these issues are given in separate sections for each of the four states.

After completion of the water-use datasets describing water use from 1864-2005, projections of future water use for 2040 were requested by the authors of the modeling report (Feinstein and others, in press) for model water-availability scenarios. An overview of the estimation methods, sources, and data for these projections is included as supplementary information in the appendixes at the end of this report because the focus of this report is the development of the initial water-use datasets.

\section{Data-Comparability Issues}

Much of the data included in these datasets can be described more as an assemblage of estimates rather than an assemblage of measured groundwater withdrawals. The water-use data published in this report may differ from the water-use data presented in other reports because of different data sources and differences in how terminologies are applied for the purposes of this study. Also, historical data were sparse in some states, thus preventing the determination of reliable estimates of water use. Therefore, trends shown in water data likely are not representative of actual historical withdrawals.

Water-use data estimated for the groundwater-flow model were assigned to the appropriate model cells. These model cells, however, did not directly coincide with state, subregion, or aquifer boundaries; that is, some model cells spanned multiple states or subregions. Therefore, some state totals among the tables do not match because the assignment of cells to each subregion or aquifer differed among the data in the tables for each state. However, the magnitude of these differences is small and is within the error of the water-use estimate.

\section{Data Descriptions}

Water-use data were compiled for Wisconsin, Michigan, Indiana, and Illinois and were limited to areas within the boundaries of the LMB model. The groundwater-flow model is divided into (1) a nearfield model area with smaller grid spacing that corresponds to the center of the model and (2) a farfield model area with larger, variable-grid spacing that corresponds to the edges of the model. The nearfield model area is the primary area of interest and roughly covers the Lake Michigan Basin area, whereas the farfield model area is included to help support analyses that may be near the Lake Michigan Basin boundaries. The Lake Michigan Basin follows hydrologic boundaries and does not exactly coincide with the rectangular nearfield model boundary. Therefore, one area in Wisconsin and four areas in Michigan extend outside the rectangular nearfield model boundary into the farfield model area (fig. 1). Water-use estimates from these areas have been compiled with the nearfield model area and subregions because these areas are within the Lake Michigan drainage. Groundwater-withdrawal data were compiled for counties in both the nearfield and farfield model areas in Wisconsin and Illinois, whereas data were compiled primarily for counties in the nearfield model area in Michigan and Indiana. For both Michigan and Indiana, groundwater withdrawals for the water-use categories in this report were compiled primarily for the counties with some portion within the Lake Michigan Basin boundary. Therefore, farfield estimates for Michigan and Indiana consist primarily of withdrawals from counties that also have withdrawals in the LMB nearfield model area. For both Michigan and Indiana, a review of withdrawals from counties in the farfield model areas indicated that withdrawals would have very little impact on model results within the nearfield model area. No water-use data were compiled for Ohio because the State is outside of the Lake Michigan Basin boundary, and almost all withdrawals are in the farfield model area (Kimberly Shaffer, U.S. Geological Survey Ohio Water Science Center, written commun., 2009). Additionally, the type and amounts of water use occurring in northwestern Ohio likely result in small drawdowns that have little influence on the exchange of water between the farfield and nearfield model areas. This area relies considerably on surface-water sources, and the minor groundwater withdrawals are primarily from shallow public-supply and industrial wells (Kimberly Shaffer, U.S. Geological Survey Ohio Water Science Center, and Daniel Feinstein, U.S. Geological Survey Wisconsin Water Science Center, oral commun., 2006).

Data in this report have been segregated for each model time interval by model area, model subregion, category of use, aquifer system, aquifer type, and hydrogeologic unit model layer (model layer) as described below.

1. Model area: Nearfield and farfield.

2. Model subregion: Northeastern Wisconsin, Southeastern Wisconsin, Northeastern Illinois, Upper Peninsula of Michigan, Northern Lower Peninsula of Michigan, Southern Lower Peninsula of Michigan, and Northern Indiana. 
3. Water-use category: Public supply, industrial, irrigation, and miscellaneous.

4. Aquifer system (group of two or more aquifers that are separated by rock units of lower permeability (for example, semiconfining and confining units)): Quaternary, Jurassic-Mississippian, Silurian-Devonian, CambrianOrdovician, and mixed (Quaternary and another bedrock aquifer system or two bedrock aquifer systems).

5. Aquifer type (the type of water-bearing formation, as described below): Shallow unconsolidated material, shallow bedrock, and deep bedrock.

6. Hydrogeologic unit model layer: Twenty model layers, listed in the stratigraphic column in appendix 1 . The hydrogeologic unit was specified to be the screened interval for unconsolidated-material wells and the interval between the bottom of the casing and the bottom of the well for bedrock wells.

Most state-level water-use data are included in this report (appendixes 2 through 5), with the exception of state water use by hydrogeologic unit model layer for each water-use category. Although details are provided in this report about how water-use data were estimated at the county level, ${ }^{2}$ no countylevel data are presented herein because of varying degrees of completeness from county to county and from state to state. Detailed descriptions of data sources and water-use-estimation methods with respect to each water-use category are described throughout the remainder of the report. Terms used in this report are defined throughout the report but are also summarized in the glossary (at the end of the report). This report converts annual volumes of water into average daily quantities in million gallons per day (Mgal/d), because annual values often involve large numbers (hundreds of thousands of gallons).

\section{Model Time Intervals}

Withdrawals for public supply, industrial, irrigation, and miscellaneous water uses were compiled and estimated for each state when appropriate for the period from 1864 to 2005. Within this period, time was broken down into 12 intervals as follows: (1) 1864-1900, (2) 1901-20, (3) 1921-40, (4) 1941-50, (5) 1951-60, (6) 1961-70, (7) 1971-75, (8) 1976-80, (9) 1981-85, (10) 1986-90, (11) 1991-2000, and (12) 2001-5. These time intervals (termed "stress periods" in the model documentation; Feinstein and others, in press) were chosen because of data availability and expected changes in water levels due to trends of large withdrawals. Thus, longer timespans generally correspond to early intervals with little available data, and shorter timespans generally correspond to intervals with large changes in withdrawal amounts and locations, and usually more available data. Because site-specific groundwater withdrawal data were not available for every year

\footnotetext{
${ }^{2}$ County-level data compiled for this report, in particular for Wisconsin and Illinois, may be obtained by readers by sending an inquiry to the authors of this report.
}

for 1864-2005, water-use estimates for some time intervals are based on only a few years of data or are based on data from adjacent intervals, as described in subsequent sections. Wateruse estimates for this study were determined for each interval and were assigned to the midpoint of each respective interval.

\section{Aquifer Units}

In addition to total withdrawals for each location, the depth - and therefore, the aquifer from which water was being withdrawn - was determined. This information also was needed as input to the groundwater-flow model, in which 20 layers were used to represent the hydrogeologic units in the LMB model area (appendix 1). Maps and descriptions of principal aquifers, hydrogeologic-unit distributions, and bedrock geology in Lake Michigan model area are available in other project-related reports (Sheets and Simonson, 2006; Lampe, 2009). For the purposes of this report, water-use information is divided into groups corresponding to the following hydrogeologic aquifer systems: (1) Quaternary unconsolidated deposits (model layers 1-3); (2) Jurassic to Mississippian (Marshall Sandstone) bedrock units (model layers 4-8); (3) SilurianDevonian bedrock units (model layers 9-12); and (4) Cambrian-Ordovician (Sinnipee to Mount Simon) bedrock units (model layers 13-20). The Quaternary unconsolidated deposits throughout the model area are typically glacial in origin but can include alluvial deposits. The bottom hydrogeologic unit of the Jurassic-Mississippian aquifer system is the Marshall Sandstone; the shale confining units of the Mississippian System were assigned in the model to the top of the SilurianDevonian aquifer system. In Wisconsin and Michigan, a few groundwater withdrawals were from or included a contributing portion of Precambrian crystalline bedrock. However, because yields were limited and this bedrock unit is not considered to be a principal aquifer, withdrawals were assigned to model layer 20 to describe contributing pumpage from the base of the Cambrian-Ordovician aquifer system. Water-use estimates also were subdivided into aquifer type on the basis of whether withdrawals were from (1) shallow unconsolidated material, (2) shallow bedrock, ${ }^{3}$ and (3) deep bedrock. ${ }^{4}$ Division of withdrawals into these groups helps to explain the varied response to pumping in different areas of the Lake Michigan Basin.

\footnotetext{
${ }^{3}$ Shallow bedrock wells in the groundwater-flow model penetrate no bedrock aquifer layer that is beneath a bedrock confining unit. For this purpose, a confining unit is defined as a bedrock unit at least $5 \mathrm{ft}$ thick and assigned a vertical conductivity less than or equal to $0.001 \mathrm{ft} / \mathrm{d}$. Shallow pumping at a given well is from unconfined or semiconfined aquifers (the latter is the case when a shallow bedrock aquifer is overlain by fine-grained glacial material).

${ }^{4}$ Deep bedrock wells penetrate at least one bedrock aquifer layer that is beneath a bedrock confining unit. Deep pumping at a given well is, at least partly, from confined aquifers.
} 


\section{Water-Use Categories}

Water use, as defined for this report, is the amount of water withdrawn from groundwater sources (water-bearing formations below land surface, also known as aquifers). A water withdrawal is the amount of water a pump actually withdrew. Water withdrawal for a site or well has been represented by one of four report-specific water-use categories: public supply, industrial, irrigation, and miscellaneous. These water-use categories were not necessary for the model input datasets but were helpful when estimating water use for each state because of the differing methods used for each category. For most states, additional data represented by other water-use categories also were estimated. For the purpose of simplifying the types of withdrawals for the model datasets, data in these other categories, such as thermoelectric and aquaculture, are included in one of the four above report-specific water-use categories. These report-specific categories, and the types of data they include, may differ from other USGS or state-specific categories because of differences in how the data were collected, classified, and estimated for each state (table 1). For example, some facilities classified as commercial water-use sites in one state may have been classified as public supply in another state, depending on the terminology applied by the respective state environmental regulatory agency or the definition in the source database. Similarly, water withdrawn for the thermal process of generating electricity is included in the reportspecific miscellaneous category for Wisconsin and is included in the report-specific industrial category for Illinois. Indiana does not have a thermoelectric power category; rather, water withdrawn for the primary purpose of power generation is classified in the energy production category and for the purposes of this report is included in the report-specific industrial category. All industrial and irrigation withdrawals estimated in this report are from self-supplied water sources. No estimates of self-supplied water uses for domestic, livestock, mining, remediation, or wastewater treatment and processing were compiled for this study.

For this report, per capita use is defined as the amount of water withdrawn by the public water-supply system (and delivered for a variety of uses, such as domestic, commercial, industrial, and public) divided by the number of persons served by the system during a standard time period, generally per day. Therefore, the public-supply per capita use values created in this study do not necessarily describe domestic use solely but include each resident's indirect participation of water used in the community for the broader public-supply uses, such as for industry.

Table 1. Description and comparison of U.S. Geological Survey or state-specific and report-specific water-use categories, by state.

[PS, public supply; IN, industrial; IR, irrigation; MISC, miscellaneous; ND, not determined; USGS, U.S. Geological Survey; shaded cells indicate category is not relevant to that state]

\begin{tabular}{|c|c|c|c|c|}
\hline \multirow{2}{*}{$\begin{array}{c}\text { USGS or state-specific } \\
\text { water-use category and } \\
\text { definition }\end{array}$} & \multicolumn{4}{|c|}{ Assignment to report-specific water-use category } \\
\hline & Wisconsin & Michigan & Indiana & Illinois \\
\hline $\begin{array}{l}\text { Public supply (USGS) }{ }^{\text {a }}- \\
\text { Water withdrawn by public } \\
\text { and private water suppliers } \\
\text { that furnish water to at least } \\
25 \text { people or have a minimum } \\
\text { of } 15 \text { connections. }\end{array}$ & 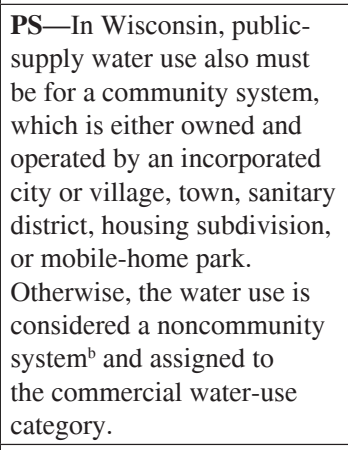 & PS & PS & PS \\
\hline $\begin{array}{l}\text { Irrigation (USGS) }{ }^{\text {a }} \text {-Water } \\
\text { applied to lands to assist } \\
\text { in the growing of crops } \\
\text { and pastures or to maintain } \\
\text { vegetative growth on } \\
\text { recreational lands such as } \\
\text { parks and golf courses. }\end{array}$ & IR & $\begin{array}{l}\text { IR-Irrigation in Michigan } \\
\text { was determined for agri- } \\
\text { cultural and golf course } \\
\text { uses. Agricultural water } \\
\text { use was determined for } 11 \\
\text { counties after 1920; golf } \\
\text { course water use was not } \\
\text { determined prior to } 1990 \text {. }\end{array}$ & IR & $\begin{array}{l}\text { IR_-Irrigation water use was } \\
\text { not determined prior to } \\
1964 .\end{array}$ \\
\hline
\end{tabular}


Table 1. Description and comparison of U.S. Geological Survey or State-specific and report-specific water-use categories, by state.Continued

[PS, public supply; IN, industrial; IR, irrigation; MISC, miscellaneous; ND, not determined; USGS, U.S. Geological Survey; shaded cells indicate category is not relevant to that State]

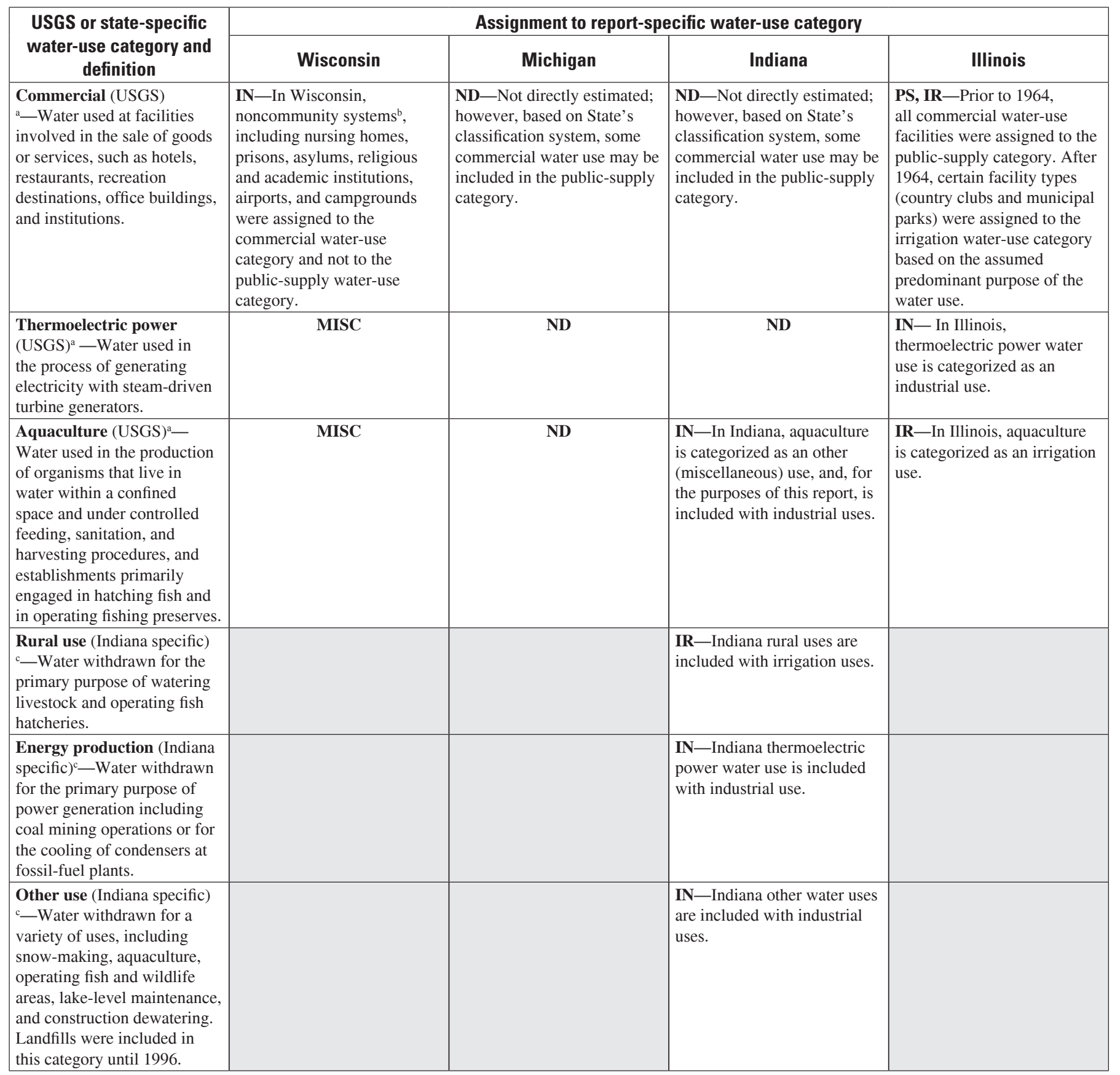

${ }^{a}$ Water-use categories generally described by Solley and others (1998).

${ }^{\mathrm{b}} \mathrm{A}$ noncommunity system is defined as a public or private water system that furnishes water year-round to less than 25 people or 15 connections, and is not owned and operated by an incorporated city or village, town, sanitary district, subdivision, or mobile-home park.

${ }^{c}$ Arvin and Spaeth (1998). 


\section{Basinwide Groundwater Use}

Overall water use for Wisconsin, Michigan, Indiana, and Illinois was relatively small during the early model time intervals but was followed by large increases that began around the 1960s (fig. 2). These increases in the 1960s are partially explained by the availability of well-log data used to determine when pumping began for facilities in the LMB model area. For the most part, early water-use estimates for Michigan and Indiana were based on either minimal reported data or no reported data at all, so the apparent trends for these two states likely are not indicative of actual water use.

Characterization of withdrawals by geographical model area and subregion was important during the development of the LMB model. In Wisconsin, withdrawals in the nearfield model area were generally larger than farfield withdrawals during early time intervals and smaller than farfield withdrawals during the later intervals (table 2). In Michigan and Indiana, water use was estimated primarily for the nearfield model area because withdrawals in the farfield model area were determined to have little impact on the nearfield results. Therefore, the farfield model areas of both Michigan and Indiana had the least amount of total water used in the LMB model. In Illinois, withdrawals before 1964 were estimated for seven major pumping centers in the nearfield model area; withdrawals after 1964 were estimated by county for the entire Illinois model area. From intervals 6 (1961-70) through 9 (1981-85), withdrawals in Illinois in the nearfield model area grew to about 3 times as much as those in the farfield model area. After interval 9, withdrawals in the nearfield model area began to decline. The majority of groundwater used in the nearfield model area during the first three time intervals (1864-1940) was in Illinois; but by the 1940s, all states except Indiana were similar in the amount of withdrawal. Since then, total water use for Michigan's nearfield model area largely has outpaced growth in water use for all other states. Water use in the Illinois nearfield model area peaked during interval 8 (1976-80) and has since declined. Withdrawals were generally smaller for the Upper Peninsula of Michigan, the Northern Lower Peninsula of Michigan, Northern Indiana, Southeastern Wisconsin, and Northeastern Wisconsin subregions compared to the withdrawal amounts for the Southern Lower Peninsula of Michigan and Northeastern Illinois subregions and the farfield model area (table 3).

Withdrawals for the public-supply category make up the majority of the withdrawals in Wisconsin, Michigan, Indiana, and Illinois (table 4). In Wisconsin and Michigan, the second largest withdrawals are for the irrigation category; in Indiana and Illinois, industrial withdrawals account for the second largest withdrawal amounts.
Associating withdrawals with specific aquifer units (which could then be related to a specific model layer) was important for model simulations (table 5). Withdrawals in Michigan and Indiana are predominantly from the Quaternary aquifer system. Withdrawals in Wisconsin are about equally from the Quaternary and Cambrian-Ordovician aquifer systems. Withdrawals in Illinois are predominantly from the Cambrian-Ordovician aquifer system. The Jurassic-Mississippian aquifer system also is an important source of water in Michigan but not in the other states. Both Wisconsin and Michigan have some wells that are completed in the unconsolidated material and underlying bedrock units (classified as a mixed aquifer system), but data from Indiana and Illinois do not specify withdrawals from any wells that are open to both of these different aquifer systems.

In Wisconsin, withdrawals from the Quaternary aquifer system are largest from the upper $100 \mathrm{ft}$ of unconsolidated deposits and from the last two model layers, which represent the Mount Simon Formation of the Cambrian-Ordovician aquifer system (table 6). In Michigan, withdrawals from the Quaternary aquifer system are largest from the upper $300 \mathrm{ft}$ of the unconsolidated deposits and from the model layers representing the Pennsylvanian Saginaw Formation and the Mississippian Marshall Sandstone Formation of the Jurassic-Mississippian aquifer system. In Indiana, withdrawals from the Quaternary aquifer system are largest from the upper $300 \mathrm{ft}$ of the unconsolidated deposits. In Illinois, withdrawals from the Quaternary aquifer system are largest from the upper $300 \mathrm{ft}$ of the unconsolidated deposits and from the model layers representing the Ironton-Galesville part of the Cambrian-Ordovician aquifer system. These aquifer systems can be further categorized by aquifer type, which is whether the aquifer unit is unconfined unconsolidated materials, shallow unconfined bedrock, or deep confined bedrock (table 7). Withdrawals in Michigan and Indiana are predominantly from the unconfined unconsolidated materials. Withdrawals in Wisconsin were predominantly from deep confined bedrock for earlier time intervals but have shifted to be about equally from unconfined unconsolidated materials and deep confined bedrock units. Withdrawals in Illinois are predominantly from deep confined bedrock. 

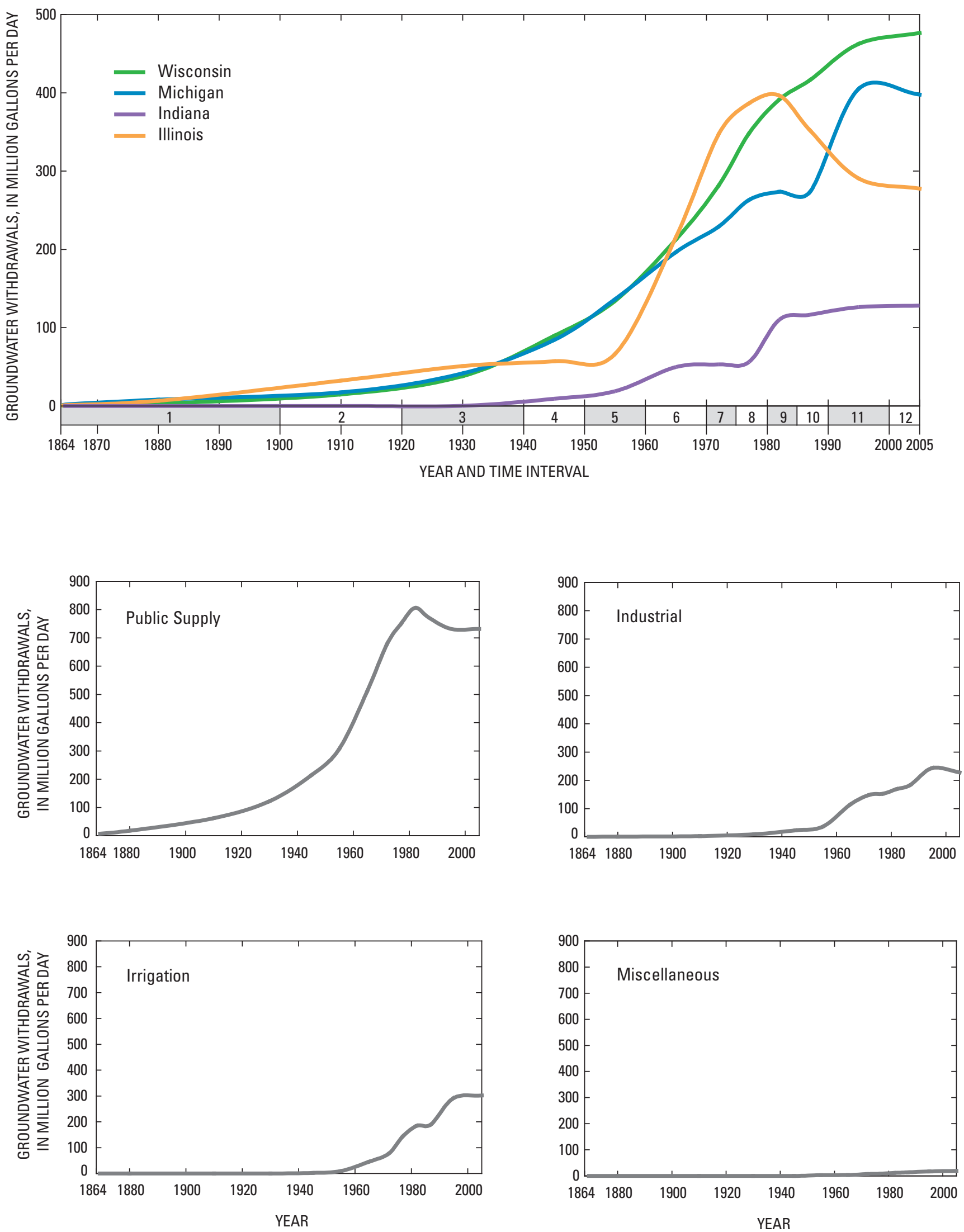

Figure 2. Groundwater-use estimates by state and by water-use category for the Lake Michigan Basin model area, 1864-2005. 


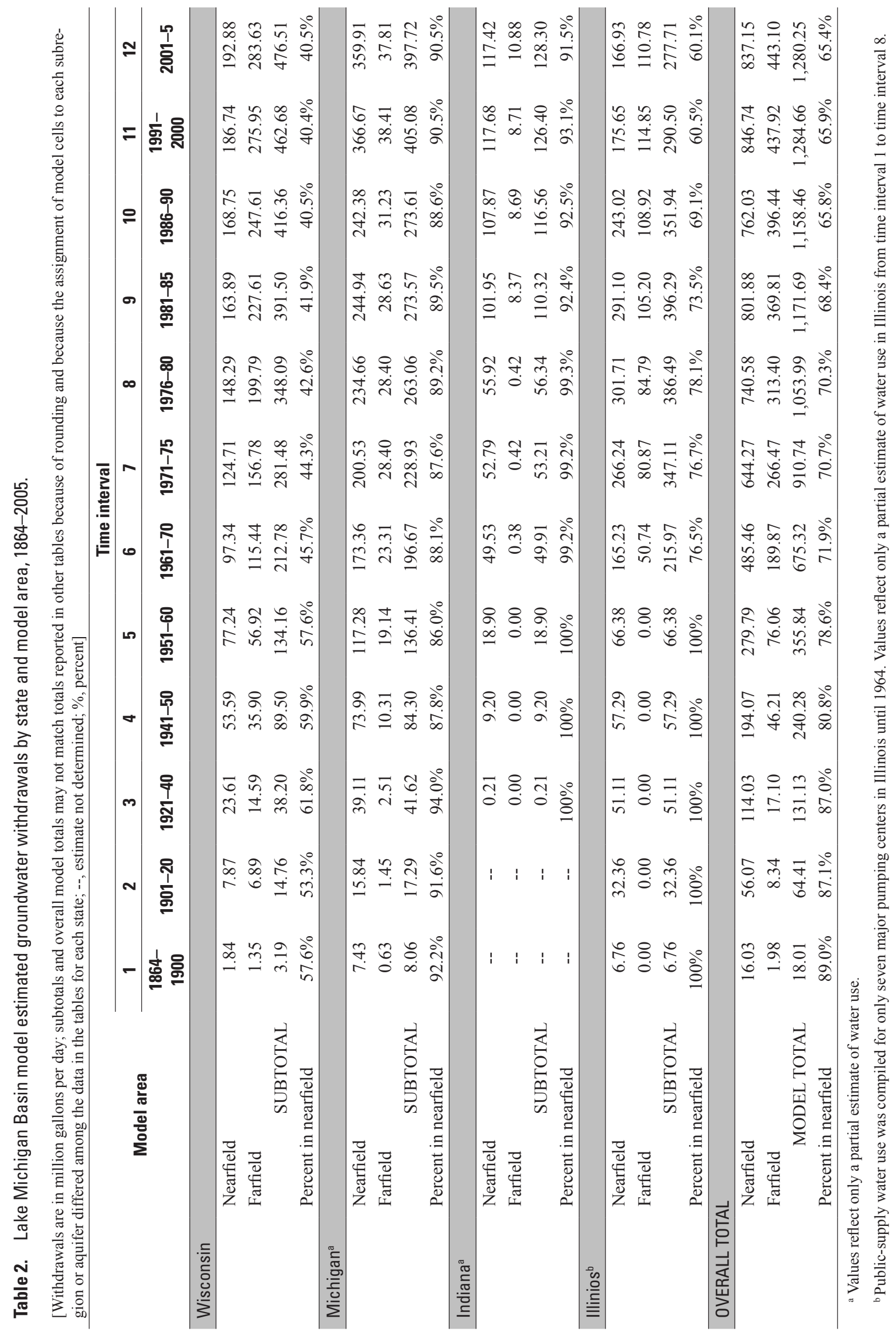




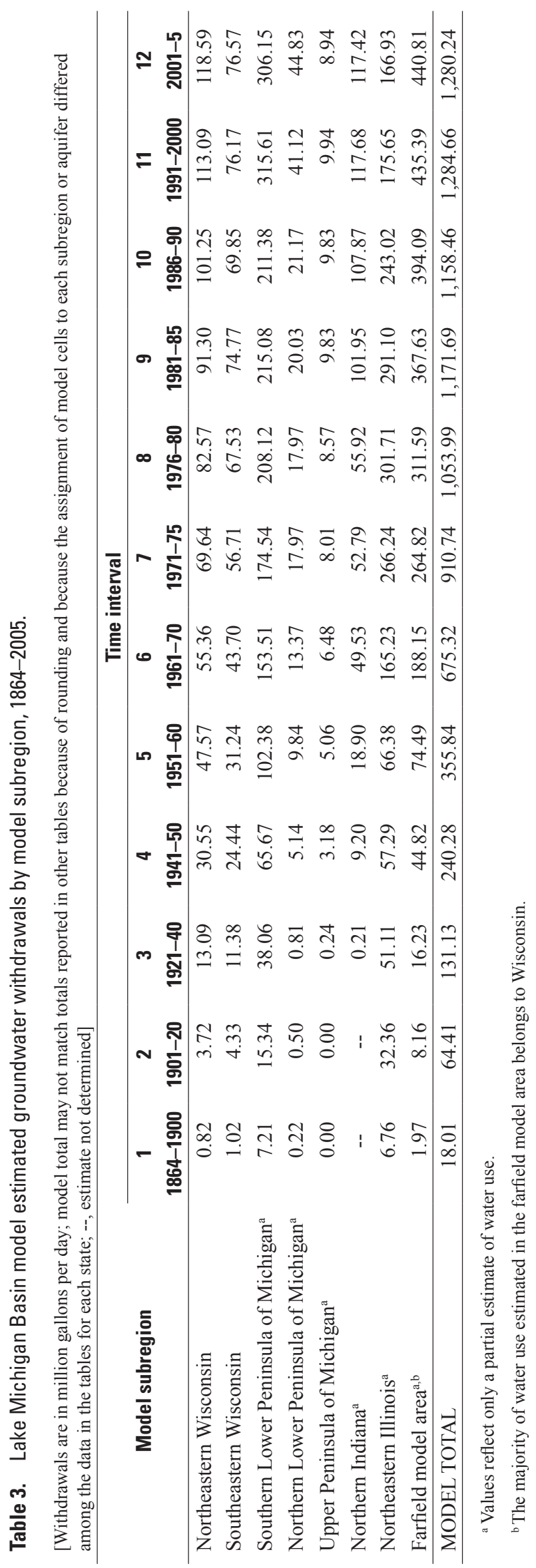




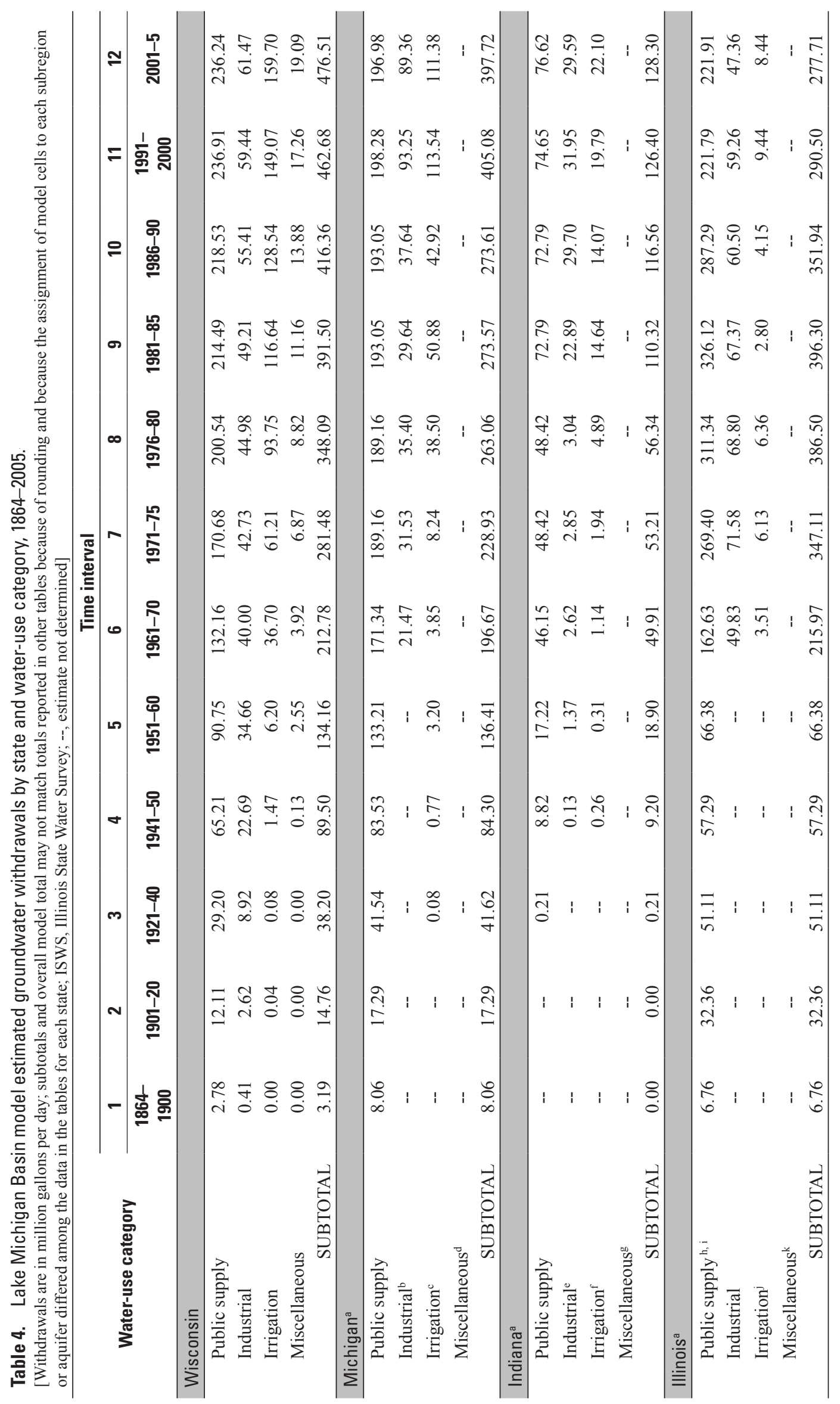




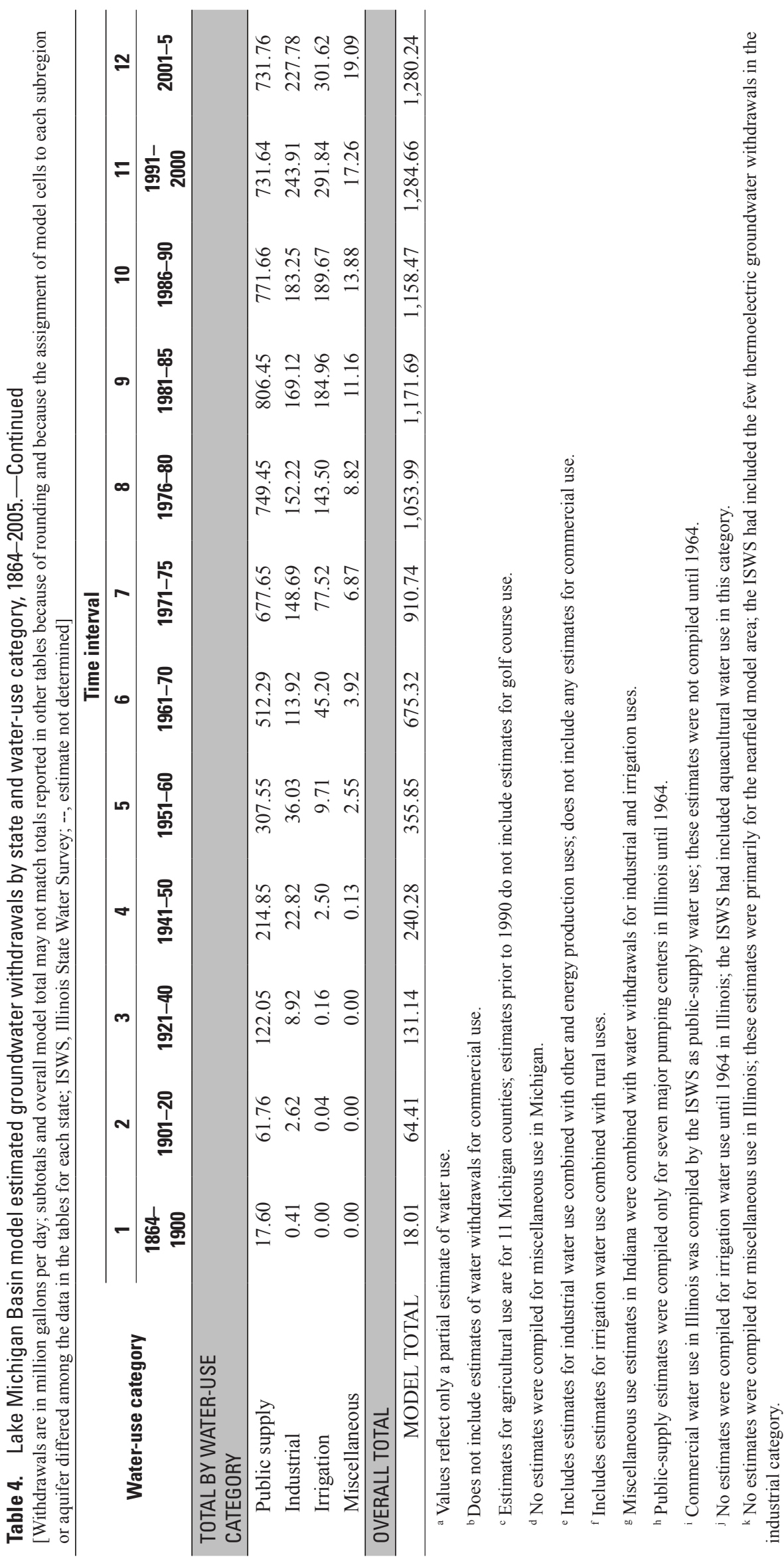




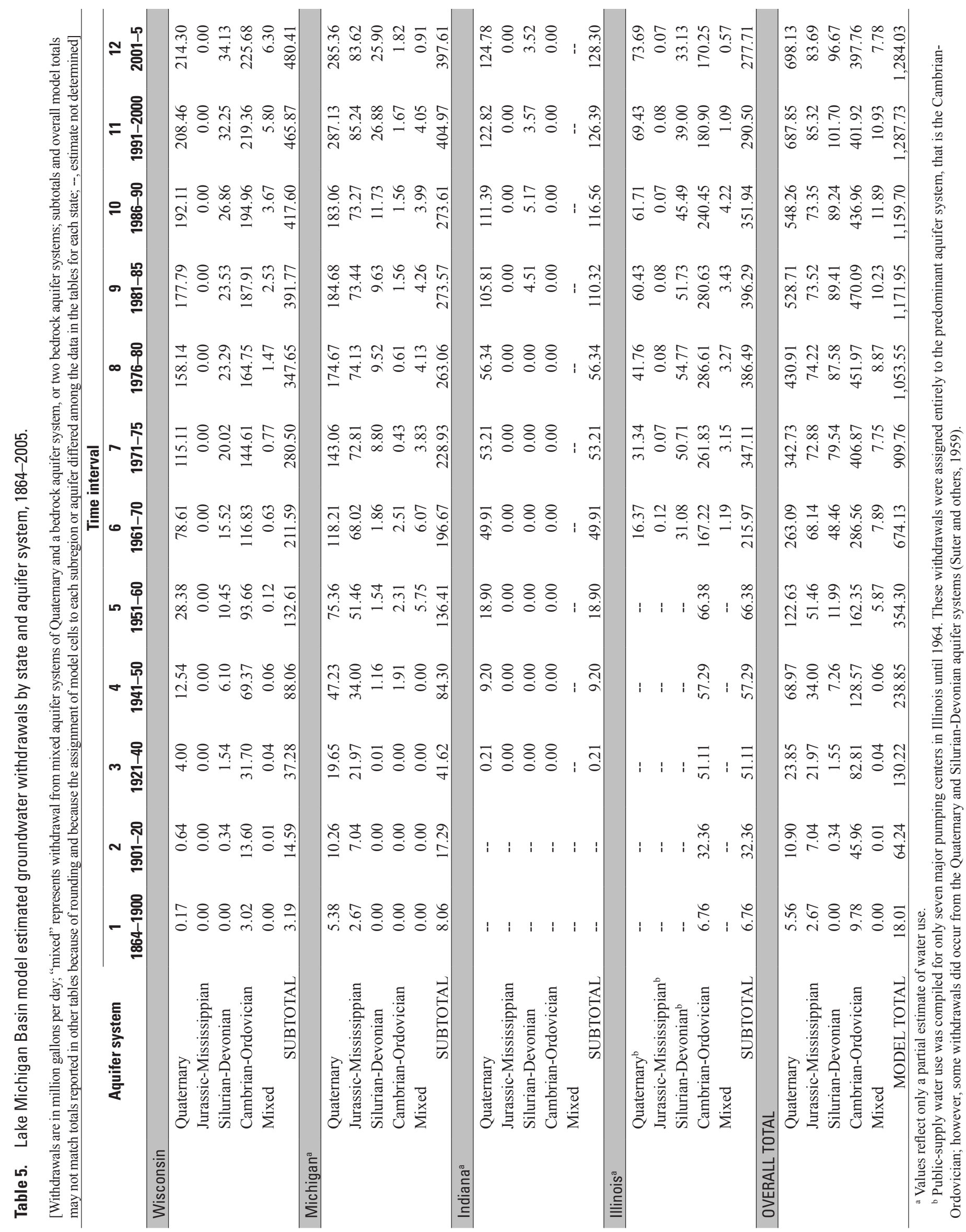




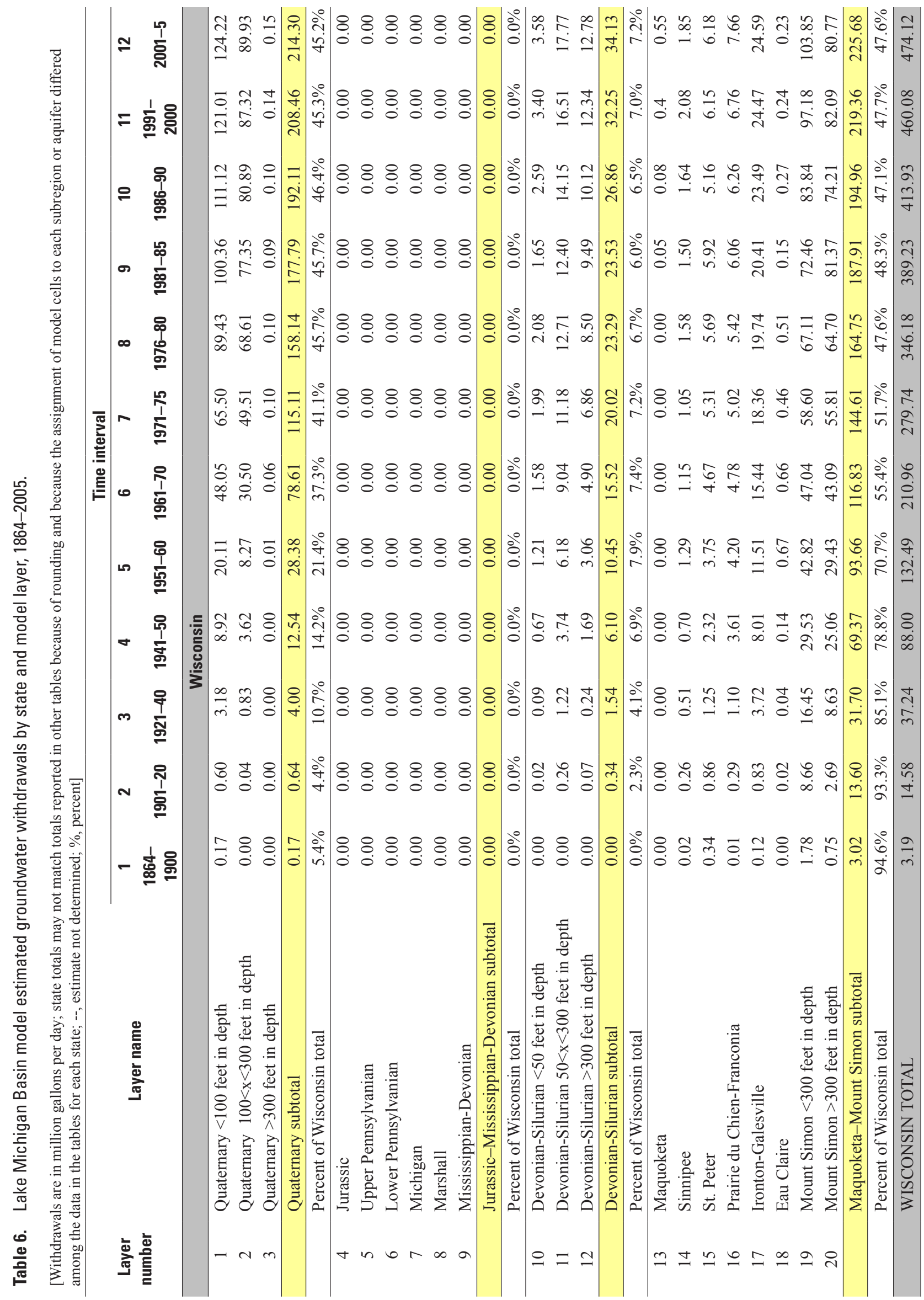




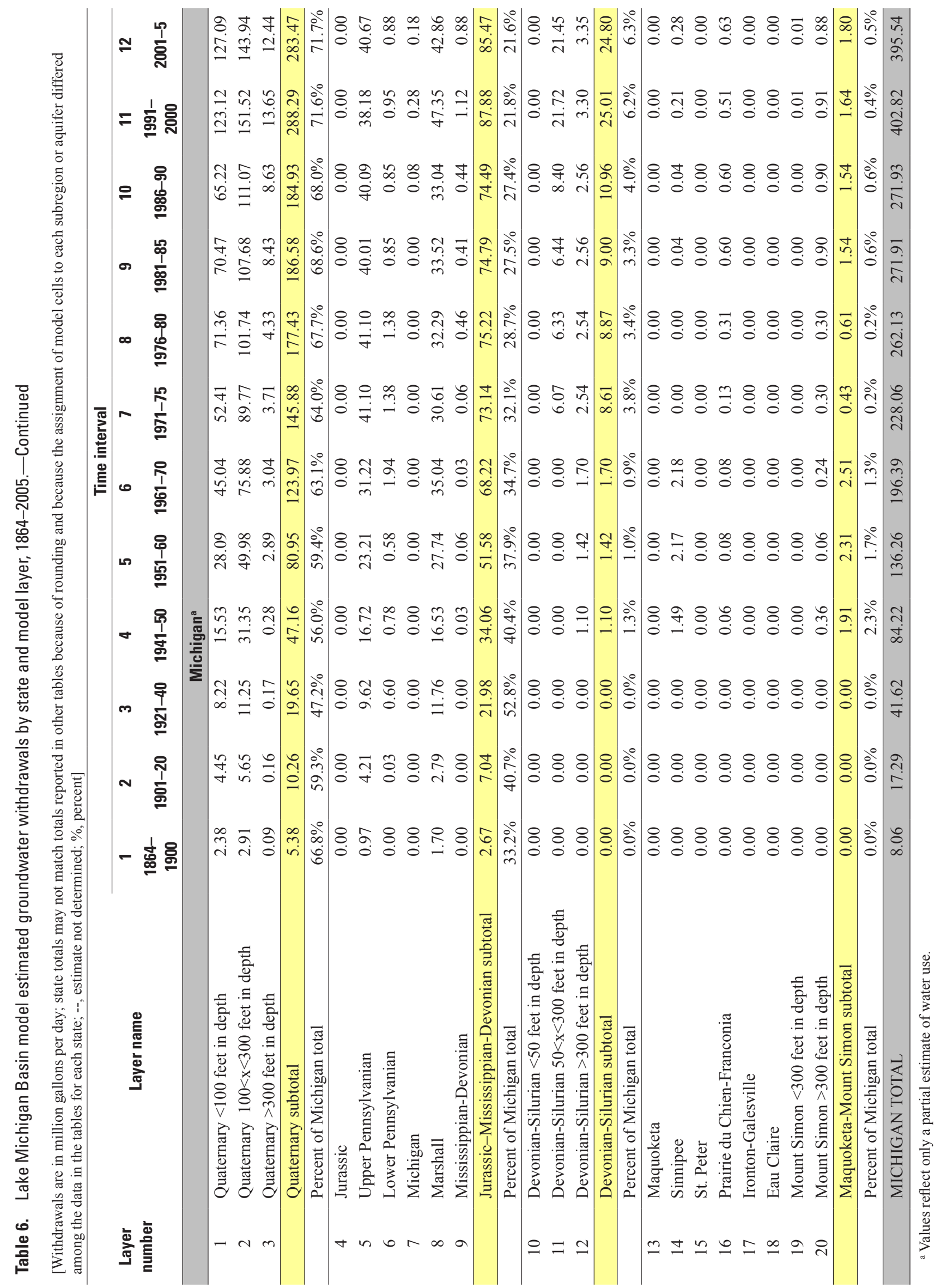




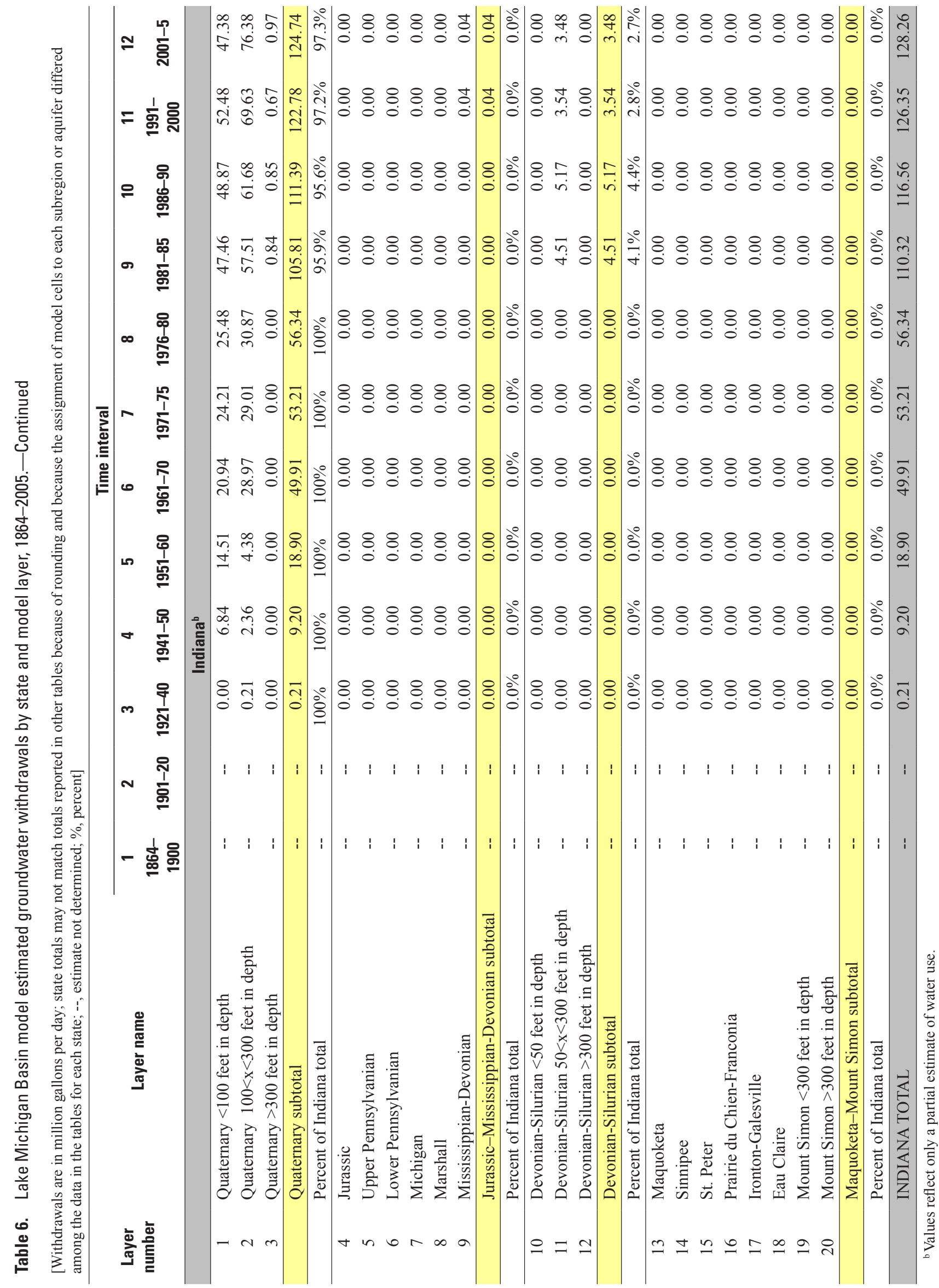




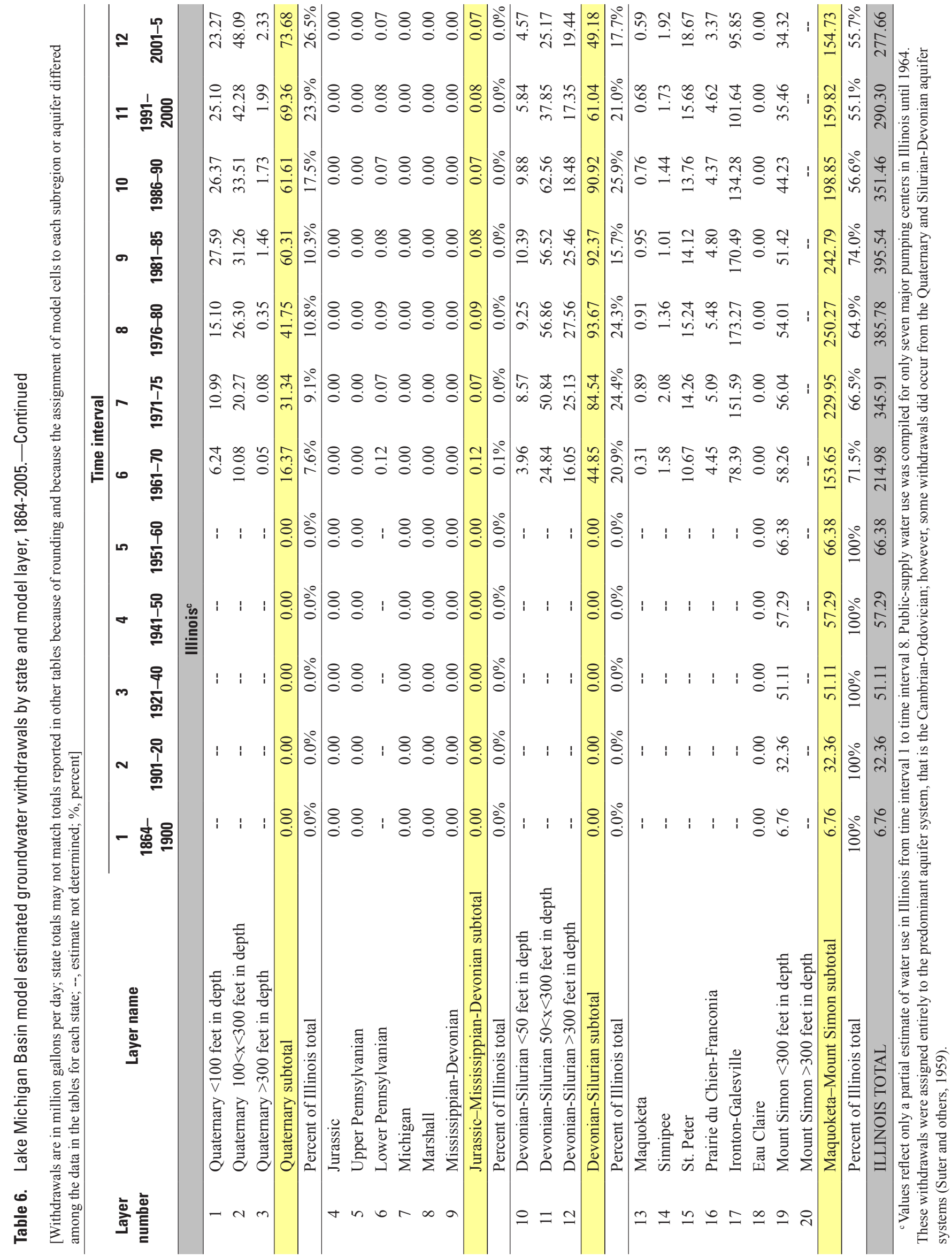




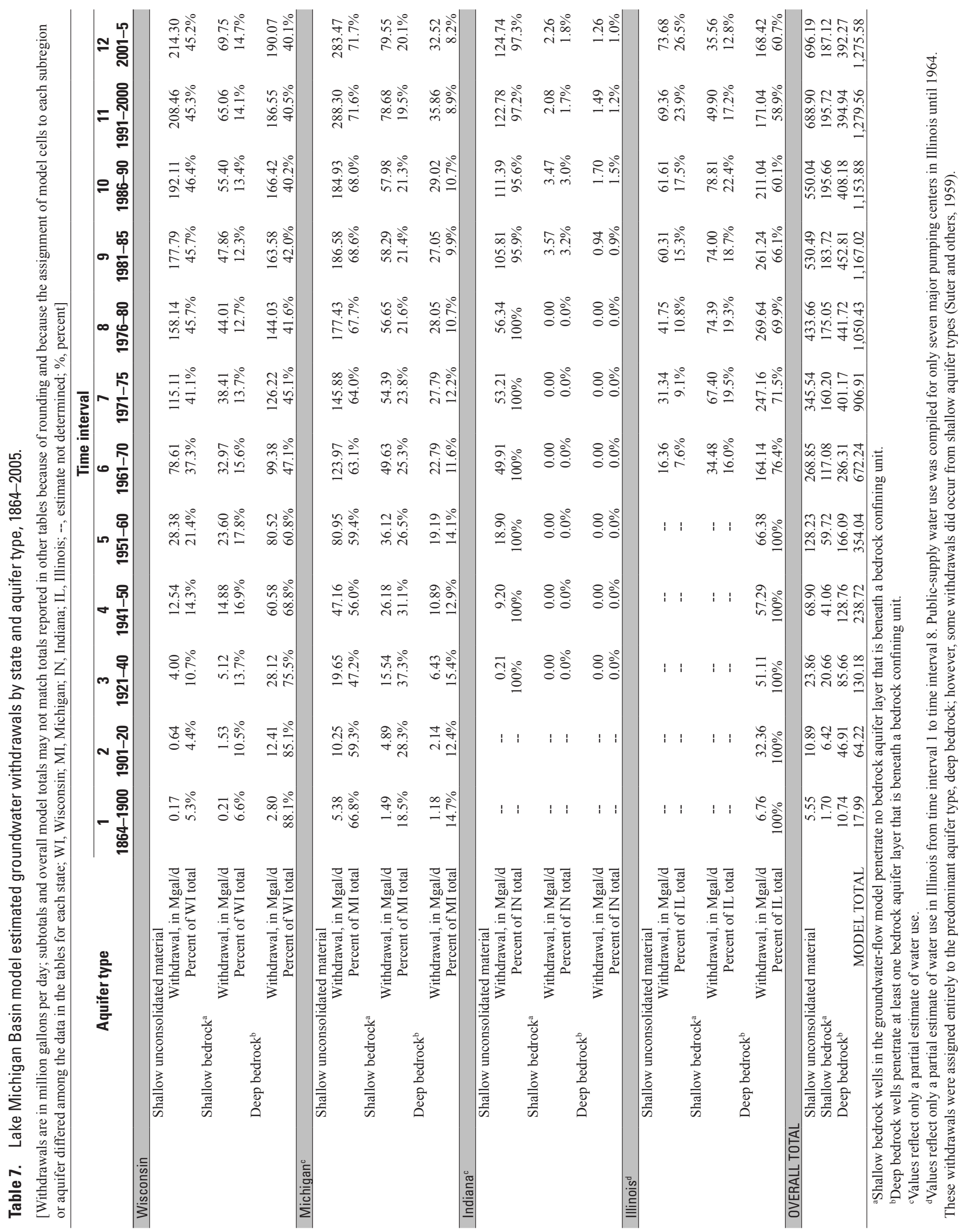




\section{Part 2: State-by-State Descriptions of Water-Use Estimates}

Groundwater use from 1864 to 2005 was estimated for Wisconsin, Michigan, Indiana, and Illinois for most areas within the boundaries of the LMB model. Subsequent sections describe the compilation and estimation of these data for those categories appropriate for each state. Each state section includes information on the history of groundwater management and water-use data collection and an overview of data used in the study, as well as the principal sources of data, the development of the estimates, and the assumptions and limitations on these estimates.

\section{Wisconsin}

\section{History of Groundwater Management and Water- Use Data Collection in Wisconsin}

In Wisconsin, only selected water-use information and data are collected and maintained. The earliest data are byproducts of State approval and permitting requirements for large water withdrawals. In 1935, the Public Service Commission of Wisconsin (PSC) began granting surface-water withdrawal approvals (sometimes called permits) for irrigation, agriculture, or maintenance of normal water levels, based on pump capacity but not actual withdrawals. Around the same time, a withdrawal from a navigable lake or stream resulting in a loss of $2 \mathrm{Mgal} / \mathrm{d}$ (averaged over a 30-day period) would also require a permit (Chapter 30.18, of Wisconsin Statutes (Wis. Stats.) of the Wisconsin Administrative Codes (Wis. Adm. Code.)). Permits of that type became a requirement in 1956 (Schmid, 1962). In June 1945, the first law regarding significant groundwater withdrawals went into effect and was administered by the Wisconsin State Board of Health, now known as the Wisconsin State Department of Health. The board developed a Section on Well Drilling and was given authority to grant well-construction and pump-installation approvals for wells considered significant (Schmid, 1961; Thomas Riewe, Wisconsin Department of Natural Resources, written commun., 2008). A significant withdrawal for groundwater was defined in Section 281.34 (formerly 144.03), Wis. Stats., as being from a well - referred to as a "high-capacity well" - with the capability of withdrawing $100,000 \mathrm{gal} / \mathrm{d}$ or more (averaged over a 30-day period). The approval systems for what could be considered significant withdrawals became the responsibility of the Wisconsin Department of Natural Resources (WDNR) Bureau of Water Quality, Bureau of Water Supply (now called the Bureau of Drinking Water and Groundwater), and Bureau of Watershed Management (Wisconsin Department of Natural Resources, 1997; Thomas Riewe, Wisconsin Department of Natural Resources, written commun., 2008) when the agency was formed in 1967. An entity wishing to make a significant withdrawal (as defined above) had to obtain approval from the WDNR before initiating the withdrawal. These approvals were used to track large withdrawals that might affect public rights (such as quantity of water available to navigable waters or a public-supply well) and health, water quality, or surface-water features, including those associated with wildlife, aesthetic concerns, or fishing and other recreational needs.

In 1978, the USGS began a cooperative program with the WDNR to inventory water use in Wisconsin. The overall goal of this program was to establish an environmental baseline and a continuing assessment of major water uses, including power generation, industrial, irrigation, and public-supply water uses. In 1985, the Great Lakes Charter was signed by states and Canadian provinces surrounding the Great Lakes to improve water planning, coordination, and management within the Great Lakes Basin (Council of Great Lakes Governors, 1985). However, by 1989, the reporting requirement for high-capacity well withdrawals, excluding those for public supply, largely had ceased. Therefore, from 1978 to 1990, some withdrawal data were reported to or estimated by the WDNR and provided to the USGS. In 2007, the enactment of Wisconsin's new groundwater-quantity legislation, known as 2003 Wisconsin Act 310 (Wisconsin State Legislature, 2004), resulted in new reporting requirements for high-capacity wells in the State.

In 2007, the definition of a high-capacity withdrawal was broadened to include any property where groundwater from all wells, holes, and shafts onsite is capable of being pumped at a combined rate totaling $70 \mathrm{gal} / \mathrm{min}$ or more (or $100,000 \mathrm{gal} / \mathrm{d}$ or more) (Section s. 281.17, Wis. Stats.). The above described property is referred to as a "high-capacity property." Therefore, in Wisconsin, the term "high capacity" is applied not only to wells with a pump (or flow) capacity of $70 \mathrm{gal} / \mathrm{min}$ or more but also to wells with a pump (or flow) capacity of less than $70 \mathrm{gal} / \mathrm{min}$ solely due to their presence on the high-capacity property. Pump capacity is the amount of water a pump is capable of moving during a specified time period, and water withdrawal is the amount of water a pump actually withdraws from the groundwater source. Thus, a high-capacity groundwater withdrawal approval remains based on pump capacity and not on actual water withdrawal. Further explanation about the most current statutes, definitions, and descriptions on groundwater quantity protection can be found in Chapter NR 820 of the Wisconsin Administrative Codes at http://www.legis.state.wi.us/rsb/index.html (Wisconsin State Legislature, 2007).

Ongoing projects have continued to produce useful information for localized water-use and availability studies. In late 2007, the WDNR began updating its inventory of the State's significant water-withdrawal facilities. The WDNR now requires that registered high-capacity well or property owners report total monthly withdrawals based on flowmeter readings, pump capacity and hours of operation, or some other alternative estimation technique (Wisconsin Department of Natural Resources, 2008a). The WGNHS continues to update the resolution of its countywide geological maps and to prepare investigation reports for the unconsolidated and bedrock 
aquifer units (Wisconsin Geological and Natural History Survey, 2008). The USGS Groundwater Systems Team began its update for 2010 of the 5-year "Water Use in Wisconsin" publication, is concluding its efforts that simulated various scenarios for using alternative sources of water to meet future demand in southeastern Wisconsin, and recently published a groundwater-flow model of the Rock River Basin (Southeastern Wisconsin Regional Planning Commission, 2010; U.S. Geological Survey Wisconsin Water Science Center, 2009).

\section{Overview of Wisconsin Data From the Lake Michigan Basin Study}

For this report, groundwater information and data from the WDNR high-capacity well approval program were combined with several other key data sources, such as well-log databases, previous groundwater-modeling project archives, information searches, and correspondence, to produce the needed groundwater-withdrawal estimates for the Wisconsin part of the LMB model. Groundwater-withdrawal estimates were compiled for the 47 easternmost counties in Wisconsin within the boundary of the LMB model, of which 32 counties, though not entirely contained, are at least partly within the Lake Michigan Basin (fig 3). Water-use locations are based on where records and information (described in this report's "Principal Data Sources" and "Additional Data Sources" sections) indicate that a substantial withdrawal had existed in earlier time intervals or that a high-capacity well permit approval existed in later intervals. Emphasis was placed on capturing high-capacity water-use locations, although additional work was done to also include well locations estimated to withdraw at least $1 \mathrm{Mgal} / \mathrm{yr}$ (or approximately $1.9 \mathrm{gal} / \mathrm{min}$ ) for a more complete inventory. Overall, 6,457 withdrawal locations were estimated in the Wisconsin part of the LMB model area, and 5,151 locations were active in the last time interval (2001-5) for a total groundwater withdrawal of $476.51 \mathrm{Mgal} / \mathrm{d}$ (table 2).

The aquifer systems available throughout the Wisconsin LMB model area are the Quaternary, Silurian-Devonian, and Cambrian-Ordovician aquifer systems. The Jurassic-Mississippian aquifer system is not present in Wisconsin and therefore is not described in this section. Further references and aquiferdistribution maps can be found in the stratigraphy report for the LMB model (Lampe, 2009). In general, groundwater development in the Wisconsin LMB model area has occurred in areas of greater groundwater availability, which have been where Quaternary deposits of glacial material can exceed $400 \mathrm{ft}$ in thickness (though maximum depth is typically around $250 \mathrm{ft}$ ) (Wisconsin Geological and Natural History Survey, 1983; Trotta, 1985; Soller, 1992; Soller and Packard, 1998), where the Silurian and Cambrian-Ordovician bedrock aquifersystem units are thick, or where the Maquoketa confining unit does not divide the flow systems into shallow and deep systems, thereby limiting vertical flow or recharge to the lower aquifer system (Wisconsin Department of Natural Resources, 1997; Southeastern Wisconsin Regional Planning Commission and Wisconsin Geological and Natural History Survey, 2002). However, settlement (that is, an increase in population) and development were extensive in areas east of where the Maquoketa Formation ${ }^{5}$ crops out; and where groundwater withdrawals were greatest, pumping has altered hydrologicflow systems, lowered groundwater levels, and reduced water quality (Wisconsin Department of Natural Resources, 1997). As a result, in 2004, two groundwater-management areas were established for northeastern and southeastern Wisconsin under 2003 Wisconsin Act 310 (fig. 3). Settlement and development have been limited in central and northern regions of Wiscon$\sin$. These areas correspond to extensive areas of wetlands, areas where unconsolidated material is thin or absent, or areas where the crystalline-bedrock basement is at or near land surface.

Well-log records collected for this study show that most early development was within the nearfield model area south of Green Bay and was within proximity of Lake Winnebago and Lake Michigan. In general, much water is still used in this part of the State, although water-use growth has been considerable in adjacent regions of the farfield model area, especially within and surrounding the Central Sand Plains of Wisconsin (which includes most central Wisconsin counties; fig. 3). Total withdrawals in Wisconsin (grouped by model area in table 2) increased consistently from $1.84 \mathrm{Mgal} / \mathrm{d}$ in time interval 1 (1864-1900) to $192.88 \mathrm{Mgal} / \mathrm{d}$ in interval 12 (2001-5) for the nearfield model area and increased from 1.35 $\mathrm{Mgal} / \mathrm{d}$ in interval 1 to $283.63 \mathrm{Mgal} / \mathrm{d}$ in interval 12 for the farfield model area. In earlier time intervals, about 60 percent of the total withdrawal for both areas was within the nearfield model area. But by interval 6 (1961-70), around 40 percent of the withdrawals were within the nearfield model area, largely because of decreasing withdrawals in some areas of the nearfield model area and increasing withdrawals in certain counties within the farfield model area. Total withdrawals by model subregion are provided in table 3 . The Northeastern Wisconsin subregion is quite extensive and covers all or parts of 24 counties, whereas the Southeastern Wisconsin subregion comprises all or parts of 9 counties (fig. 3); therefore, total withdrawals in the Northeastern Wisconsin subregion for most time intervals are greater than those in the Southeastern Wisconsin subregion (table 3; the exceptions are the first two intervals (1864-1920)). The withdrawals in Northeastern Wisconsin increased from $0.82 \mathrm{Mgal} / \mathrm{d}$ in interval 1 (1864-1900) to $118.59 \mathrm{Mgal} / \mathrm{d}$ in interval 12 (2001-5). The withdrawals in Southeastern Wisconsin increased consistently from 1.02 $\mathrm{Mgal} / \mathrm{d}$ in interval 1 (1864-1900) to $76.57 \mathrm{Mgal} / \mathrm{d}$ in interval 12 (2001-5), with the exception of a minor downturn in interval 10 (1986-1990).

\footnotetext{
${ }^{5}$ The extent and thickness of hydrogeologic units, including the Maquoketa Formation, are illustrated and discussed in the Lake Michigan Basin model stratigraphy report (Lampe, 2009).
} 


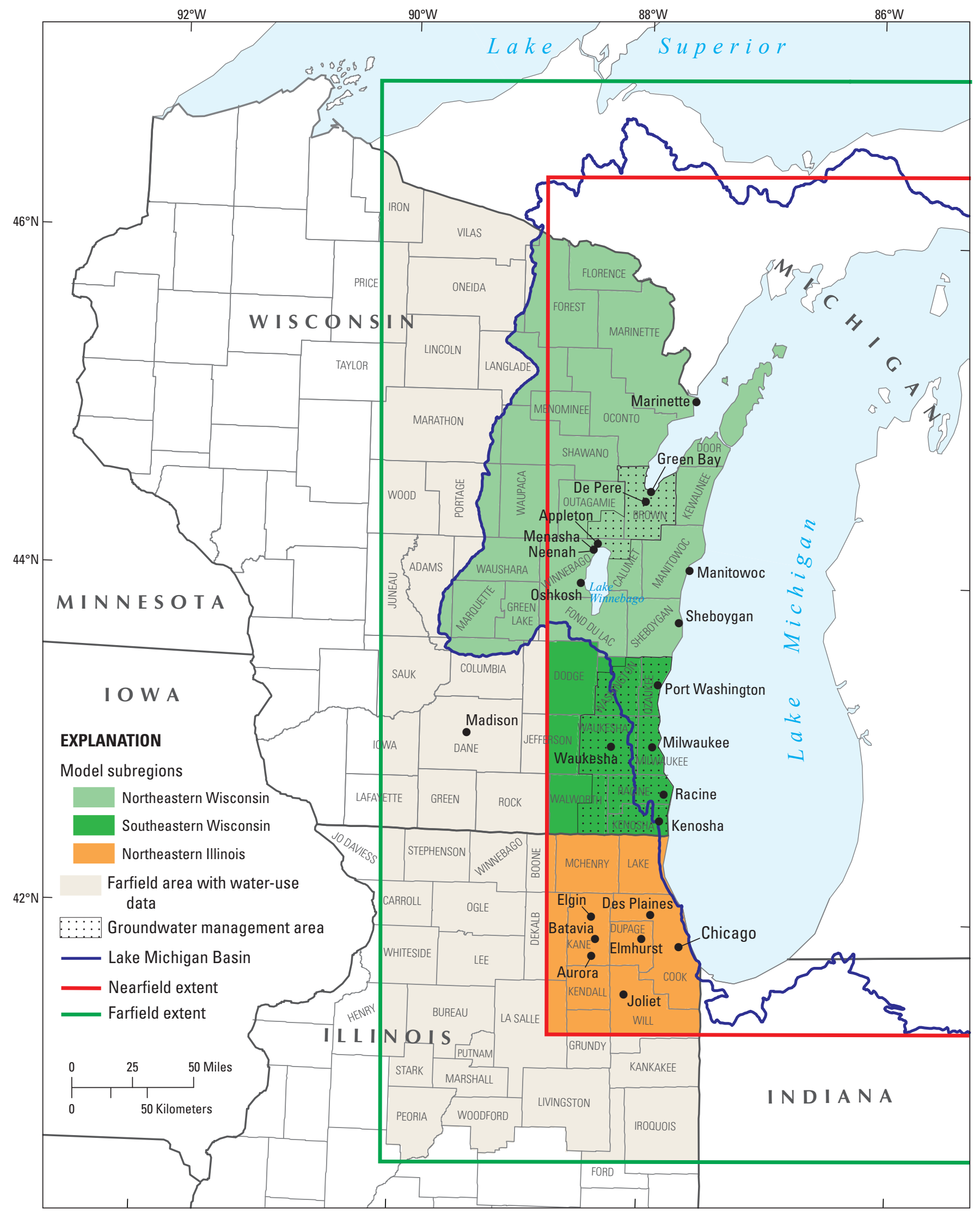

Figure 3. Wisconsin and Illinois model areas of the Lake Michigan Basin model. 


\section{Principal Wisconsin Data Sources}

Groundwater withdrawals and other water-use information were compiled from USGS and State agencies' databases, published reports, and responses to inquiries. Much water-use information was available for all categories considered in this report. The data sources overlapped somewhat. Most wellconstruction details, including well-construction date, depth, and lithological descriptions, were retrieved from the WDNR Bureau of Drinking Water and Groundwater Water Well Data CD-ROMs (Wisconsin Department of Natural Resources, 2006, 2007) and the Groundwater Retrieval Network and High Capacity Well (GRN) database (Wisconsin Department of Natural Resources, 2005), the State wiscLITH database (Wisconsin Geological and Natural History Survey, 2004), and two USGS National Water Information System databases: the Groundwater Site-Inventory (GWSI) System and the Site-Specific Water-Use Database System (SWUDS) (U.S. Geological Survey, 1998). Hydrogeologic-unit assignments and withdrawal data from previous groundwater-flow models were considered and were either compared to or integrated with the LMB model water-use database. Water-use databases were available from groundwater-flow models of the northern Midwest United States, northeastern and southeastern Wisconsin, Lower Fox River communities, Fond du Lac County, and Dane County (Mandle and Kontis, 1992; Conlon, 1998; Jansen and Rao, 1998; Walker and others, 1998; Krohelski and others, 2000; Cherkauer and Carlson, 2002; Feinstein and others, 2004, 2005). By linking these databases, information about each well was obtained with regard to ownership, operator name, well name, location, identification number, well status, construction details, aquifer, water-use category and purpose, pump characteristics, and water withdrawal.

At the time of this investigation, only water-use data for publicly owned public supplies are being reported to the WDNR and WI PSC. The WDNR collects monthly data by well, and the WI PSC collects monthly and annual data by public-supply system. The WDNR data are not readily accessible but the WI PSC data are. These data are summarized by the WI PSC in annual utility reports. Reports after 1996 can be accessed at http://psc.wi.gov/apps/annlreport/default. aspx. The USGS routinely collects these data from the above agencies. Some monthly water-withdrawal amounts for major water-use types were available between 1978 and 1990 from the WDNR and USGS, as described in a previous report section; these data were stored in the WDNR GRN and USGS SWUDS databases. However, the accuracy and completeness of those monthly and annual values are varied and limited (William Furbish and Jeffrey Helmuth, Wisconsin Department of Natural Resources, oral communs., 2004). Some additional annual water-withdrawal amounts for mostly public supply but also some industrial uses not in the WDNR GRN database were available from 1935 to 1994 from USGS databases.

If no water-use data were available or other estimation method could be applied for a particular area of Wisconsin, then Minnesota water-use records from 1988 to 2005 were analyzed by the coded water-use permit type to help develop default groundwater-withdrawal values. The State of Minnesota Department of Natural Resources Water Appropriations Permit Program (hereafter referred to as MNDNR WAPP) collects and makes available water-use data from permit holders capable of withdrawing more than 10,000 gallons of water per day or $1 \mathrm{Mgal} / \mathrm{yr}$ (Minnesota Department of Natural Resources, 2007). More information about the program and data can be obtained at http://www.dnr.state.mn.us/waters/ watermgmt_section/appropriations/wateruse.html.

The remaining water-use data were compiled from previous investigations, data-compilation efforts, and inquiries, or the data were estimated for this study. If there were water-use data representing multiple years within a model time interval, then the average of these data was assigned to the middle year of the model interval. For Wisconsin, the average pumping rate over a time interval might have included years of inactivity (zero pumping); therefore, the final water-use rate for that interval was distributed proportionally. For example, if a well went online in 1963 for $10 \mathrm{Mgal} / \mathrm{yr}$, then the number of years a well was active during the corresponding 10 -year time interval (1961-70) was 8. Therefore, the water-use rate for this time interval is reported herein to be $8 \mathrm{Mgal} / \mathrm{yr}$ in order to reflect the 2 years the well was not in operation. Years of inactivity included years prior to well construction, as in the example, and years when no pumping occurred.

Most well listings in the principal source databases include location information. The WDNR assisted in identifying public-supply wells that were active or inactive in 2004 (Amy Ihlenfeldt, Wisconsin Department of Natural Resources, unpub. data, 2007). If location was uncertain, an effort was made to assign a location of a well near other existing wells with the same ownership within the same county or by using an Internet search for the well owner or operator name; otherwise, the site was excluded. For a few wells, street-intersection information, aerial photos, or topographic maps were used to determine the well location. An effort also was made to identify locations that were in error.

Population data for counties in the Wisconsin model area were compiled by decennial census years from 1900 to 2000 from the U.S. Bureau of the Census reports (Forstall, 1995; U.S. Department of Commerce-Bureau of the Census, 2006). Decennial population data for communities within these counties were compiled from Census Bureau reports starting in 1970. Additional annual population estimates starting in 1973 through 2005 came from the Wisconsin Department of Administration (WI DOA) (Wisconsin Department of Administration-Demographic Services Center, 2006). Additional community population data that could be readily obtained were added for several east-central counties in Wisconsin for 1950 and 1960 (East Central Wisconsin Regional Planning Commission, 2007), seven counties in southeastern Wisconsin (Southeastern Wisconsin Regional Planning Commission, 2004), Oconto County for decennial years 1900 to 2000 (Oconto County, 2007), and communities identified as being only partially served by a public water-supply system (Environmental 
Working Group (EWG), 2005; U.S. Environmental Protection Agency (USEPA), 2006). However, most community population data prior to 1970 were not readily available, so they were estimated by the authors when needed for a public watersupply-well withdrawal estimate. These pre-1970 population estimates were based on the 1970-2000 average percentage of the community population residing within the county. Since 1900 , more than 70 percent of Wisconsin's population has resided within the Wisconsin model area. More than half of the Wisconsin population resides within the nearfield model area, and about half resides within the Great Lakes Basin.

\section{Public-Supply Water Use in Wisconsin}

Most public water-supply systems within the LMB model area rely on groundwater sources. The types of communities in Wisconsin that are very likely to have public water-supply systems are cities ${ }^{6}$ and villages, ${ }^{7}$ as well as many towns, ${ }^{8}$ sanitary districts, ${ }^{9}$ housing subdivisions, and mobile home parks. The oldest public water-supply systems relying on groundwater are the City of Waukesha, in Waukesha County (1886), and the City of De Pere, in Brown County (1886) (Knowles and others, 1964; Southeastern Wisconsin Regional Planning Commission, 2008). Relative to other water-use categories, the proportion of groundwater withdrawal for public supply has changed over the model time intervals. Before interval 5 (years before 1951), public-supply withdrawals accounted for about 80 percent of total groundwater withdrawals within the LMB model area, whereas those after interval 9 (years after 1985) accounted for about 52 percent of the total groundwater withdrawals (table 4). This change is mainly due to increasing groundwater withdrawals for irrigation and miscellaneous uses. Most of Milwaukee County and the larger cities of Port Washington, Sheboygan, Marinette, Appleton, Menasha, and Oshkosh originally relied on surface-water sources and therefore are not in the model water-use database (fig. 3). The City of Neenah and several large shoreline communities such as Green Bay, Manitowoc, ${ }^{10}$ Kenosha, and Racine switched to a surface-water source as water demand grew, especially between 1940 and 1970. These larger surface-water utilities may distribute water to other neighboring communities. Additionally, a handful of utilities supply both groundwater and surface water. In the last 2 time intervals (1991-2005),

\footnotetext{
${ }^{6}$ Defined by Subchapter I of Chapter 62 and Subchapter II of Chapter 66 of the Wis. Stats. (Wisconsin State Legislature, 2009).

${ }^{7}$ Defined by Chapter 61 and Subchapter II of Chapter 66 of the Wis. Stats. (Wisconsin State Legislature, 2009).

${ }^{8}$ Defined by Subchapter I of Chapter 60 of the Wis. Stats. (Wisconsin State Legislature, 2009).

${ }^{9}$ Defined by Chapter 200 of the Wis. Stats. (Wisconsin State Legislature, 2009).
}

${ }^{10}$ Manitowoc switched to using surface water as a primary source in 1969 but still relies on groundwater for approximately 14 percent of the combined withdrawal.
10 additional communities switched to or supplemented their groundwater supplies with surface water from Lake Michigan. As of 2005, further water-supply plans have been underway in southeastern and northeastern Wisconsin to switch to surfacewater sources or to evaluate service-area expansion and additional withdrawals for public supply from Lake Michigan (Central Brown County Water Authority, 2007; Southeastern Wisconsin Regional Planning Commission, 2010).

Estimated total groundwater withdrawals for public water-supply systems in the Wisconsin LMB model area range from $2.78 \mathrm{Mgal} / \mathrm{d}$ for the first time interval (1864-1900) to more than $236 \mathrm{Mgal} / \mathrm{d}$ for each of the last two intervals (1991-2005) (table 4). Figure 4A shows that public-supply withdrawals rapidly increased between interval 3 (1921-40) and interval 8 (1976-80). Then, public-supply withdrawals increased more slowly and tended to stabilize in last two time intervals, 11 and 12. This general stabilization, and even a decline in some localized areas, is due in part to the decline of certain groundwater-intensive manufacturing industries, increased water-efficiency standards, and implementation of leak-detection programs and water-conservation practices. Total public-supply water-use data by model area are listed in appendix 2 . The nearfield model area typically has between 44 to 55 percent of the total public-supply withdrawal of each time interval. Before interval 6 (1961-70), public-supply withdrawals in the Northeastern Wisconsin subregion tended to be greater than those in the Southeastern Wisconsin subregion. Since that time, coinciding with when the City of Green Bay switched supply to surface-water sources, the amounts of the withdrawals by the two subregions have tended to be more evenly balanced.

Most individual communities within the Wisconsin LMB model area developed their public water supply over time within a single respective aquifer system. A few communities were exceptions, with wells open to mixed aquifer systems. A few utilities in later time intervals were identified as having historical public-supply water use from either the Quaternary aquifer system or the Cambrian-Ordovician aquifer system but began blending water withdrawn from other aquifer systems, typically to avoid contamination, meet water-quality standards, or improve well yield. Total public-supply withdrawals by aquifer system for Wisconsin are shown in figure $4 B$ (appendix 2). Public-supply groundwater withdrawals over the 12 time intervals were primarily from the CambrianOrdovician aquifer system followed by the Quaternary aquifer system, whereas minimal withdrawals were from the SilurianDevonian aquifer system because the aquifer is limited to an area in far eastern Wisconsin. The majority of public-supply groundwater withdrawals were from deep, confined-bedrock wells. But withdrawals from unconfined unconsolidated material and shallow unconfined bedrock aquifers also were considerable (fig. $4 C$, appendix 2). 

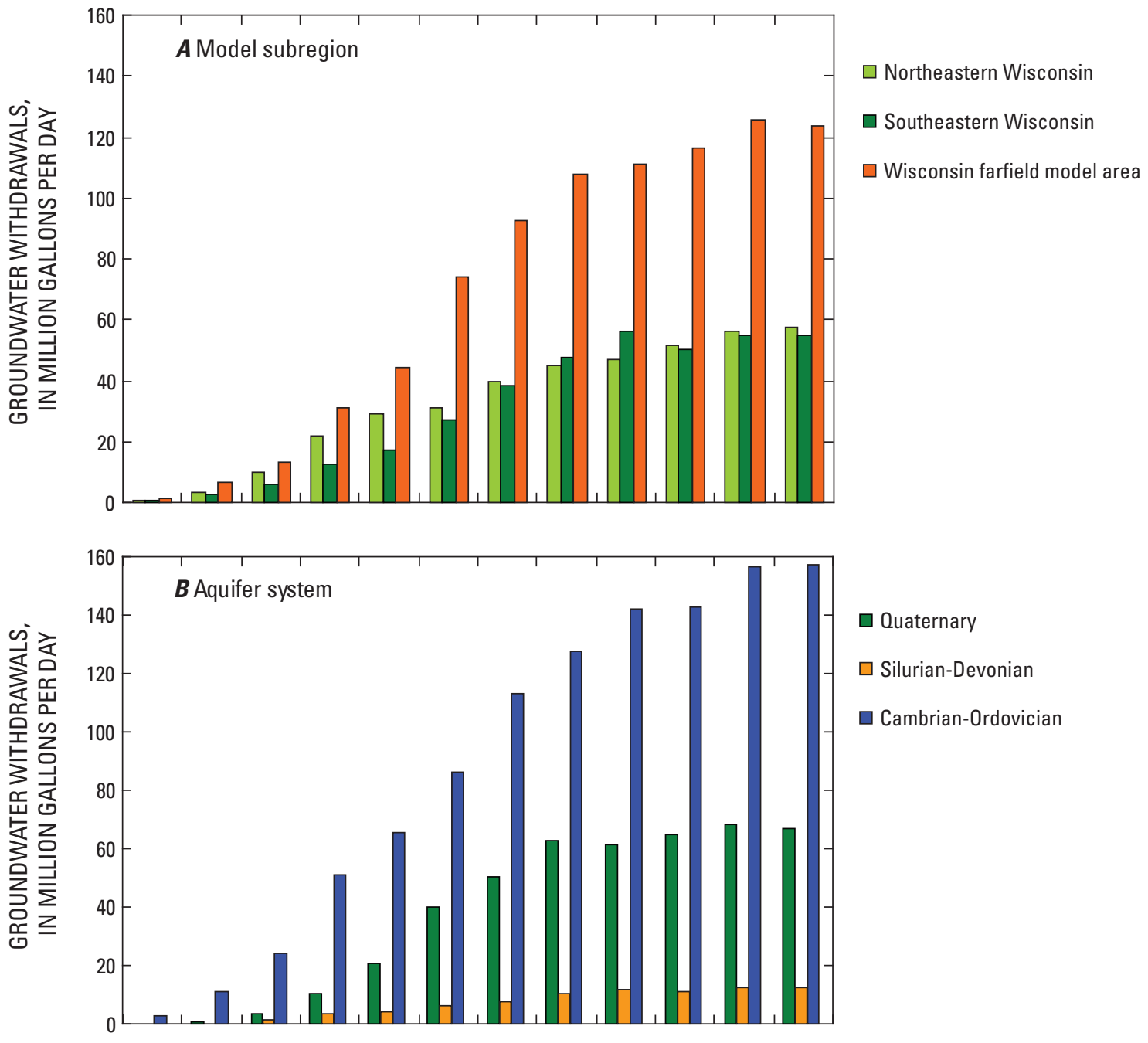

$\square$ Quaternary

$\square$ Silurian-Devonian

$\square$ Cambrian-Ordovician

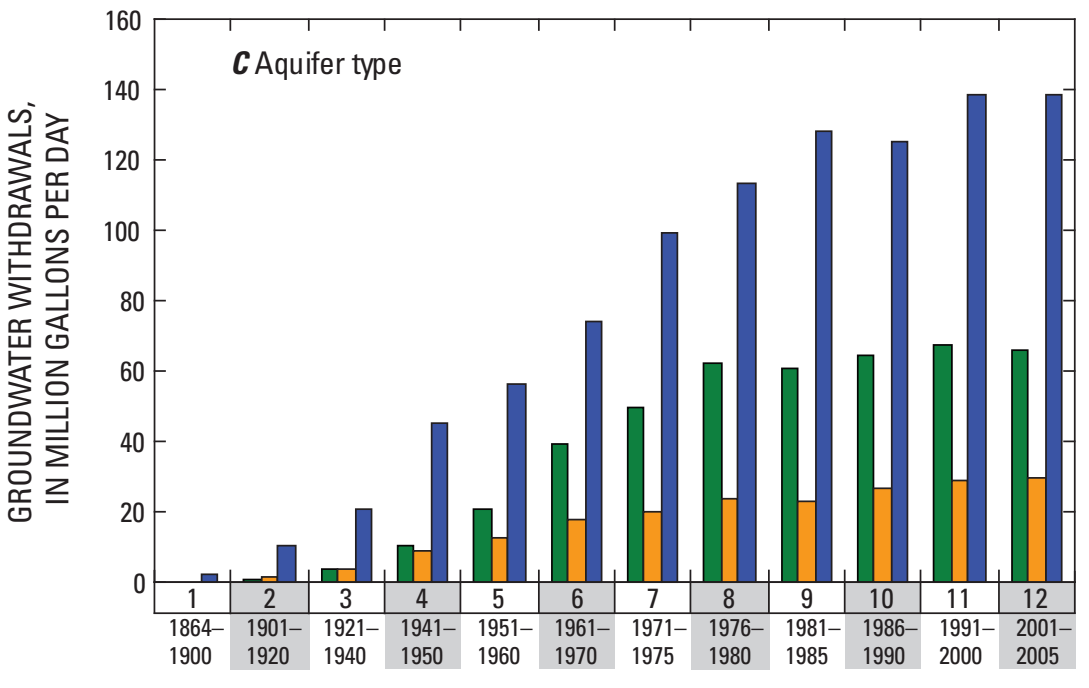

๑ Shallow unconsolidated material

$\square$ Shallow bedrock

Deep bedrock

TIME INTERVAL AND YEARS

Figure 4. Public-supply groundwater-use estimates in Wisconsin for the Lake Michigan Basin model by time interval and $A$, model subregion, $B$, aquifer system, and $C$, aquifer type. Mixed aquifer systems were removed from the graph because all data are less than 0.25 million gallons per day and there are zero estimated withdrawals from these systems for the other water-use categories. The Jurassic-Mississippian aquifer system does not exist in Wisconsin. 


\section{Additional Wisconsin Public-Supply Data Sources}

Groundwater-withdrawal data for public supply were extracted largely from the USGS SWUDS database, previous groundwater-flow models, and previously published reports including those by LeRoux (1957), Knowles (1964), Knowles and others (1964), and Hutchinson (1970). Additional withdrawal data were derived from other USGS water-use datasets, Web sites, written communications, and estimations based on population and per capita use coefficients. The first reports listing public-supply withdrawals by well or by utility in Wisconsin were for 1979 (Lawrence and Ellefson, 1982; Lawrence and others, 1984). Other reports were used solely to compare public-supply estimates for particular time periods, such as those by Foley and others (1953), Newport (1962), Green and Hutchinson (1965), and Olcott (1966). Additional withdrawal data for public supply, by well, were available for 1994 and 1997 from archived data at the USGS Wisconsin Water Science Center. Withdrawal data by water utility, not by well, for 1988 through 2005 were provided by the Public Service Commission of Wisconsin Division of Water (Bruce Schmidt, Public Service Commission of Wisconsin, unpub. data, 2006). Several inquiries to personnel at water utilities in the nearfield model area helped to clarify historical and present water use and obtain details such as the utility establishment year or the number of wells in operation during a particular time interval.

Reported geologic information along with the reported well depth came primarily from the wiscLITH and GWSI databases. That information was used to determine the hydrogeologic unit(s) to which each withdrawal site was open. If no depths were reported, the average casing and well depths from all other wells by the same utility were substituted. These data sources also provided the majority of well-construction dates, which were helpful for determining when the well became active. Altogether, in the final model water-use dataset for Wisconsin, there are 373 public water-supply systems and 1,206 public-supply wells with associated water-use estimates.

\section{Estimation Methods for Wisconsin Public-Supply Withdrawals}

Wisconsin public-supply withdrawal estimates were compiled by well for counties within and along the nearfield model area and by water utility for most counties within the farfield model area. For most wells in the model area, withdrawal data were available for the years 1970, 1979, 1984, 1989, 1994, and 1997, and in southeastern Wisconsin for 2001. Additional withdrawal data for various years not previously listed were available for fewer wells. The estimation approach began by first determining an average withdrawal for each community well for the three most recent time intervals (1986-2005) by averaging the available reported data in each interval. These averages were then used to approximate each well's percentage of the water utility's total annual withdrawal. If reported amounts for 1988 to 2005 were unavailable for an active well, then a percentage from a nearby time interval or the average surrounding intervals was used. These percentages were then used to better approximate individual well-withdrawal rates and to verify that withdrawals for the water utility's wells equaled the utility's annual total withdrawal. For time intervals before 1988, water withdrawals were estimated by using four generalized methods: (1) deriving withdrawals from estimated public-supply per capita use values and population, (2) accessing water-use data archived at USGS Wisconsin Water Science Center, (3) making inquiry to the water utility, or (4) using any combination of methods 1,2 , or 3 .

In order to estimate public-supply withdrawals by the first method, per capita use was calculated from available withdrawal and population data. Calculations of per capita use largely correspond with two time groupings because withdrawal data were infrequently available before 1970 and readily available after 1988 . During the six most recent time intervals (1971 through 2005), most public-supply per capita use values were determined from total annual reported community withdrawals divided by population. Population estimates for communities served by public water-supply systems were mostly reported for the six most recent time intervals (1971 through 2005). Population for all community types listed earlier, except for towns, are based on the assumption that 100 percent of the population was served by public supply. Towns were handled differently because they are, typically, only partly served. The town population served was based on current estimates of population served (Robert Biebel, Southeastern Wisconsin Regional Planning Commission, written commun., 2007) or on values reported by the EWG or listed in the USEPA Safe Drinking Water Information System (SDWIS) database (Environmental Working Group, 2005; U.S. Environmental Protection Agency, 2006). From these population values, the current proportion of the town served by the public water-supply system was applied to the past total populations of the town reported by the WI DOA.

For five of the remaining six earlier time intervals (1901 through 1970), public-supply per capita use was estimated for each community by starting in 1901 with a reference per capita use of $0.01 \mathrm{Mgal} / \mathrm{yr}$ per person (or $27 \mathrm{gal} / \mathrm{d}$ per person). A linear series for per capita use for each community was then applied until the first-year per capita use could be more accurately calculated, which was between 1950 and 1980 (by the method described in the above paragraph). During interval 1 (1864-1900) only a handful of communities had a public water-supply system. For those that did, half of the 1901 per capita rate (or $14 \mathrm{gal} / \mathrm{d}$ per person) was used. The average percentage for each community's population that was served by a public water-supply system was determined from the Census of Population data for 1970, 1980, 1990, and 2000. This percentage was applied to the earlier county population data (1900-1960) for the six earlier intervals (1864 through 1970). Once per capita use was determined, the public-supply estimates were developed by applying the per capita use as a coefficient to community population for each time interval without reported total withdrawals. These public-supply withdrawal estimates were then divided by the number of wells identified as being active in each interval. 
Per capita use for public supply varied by time interval and by community (fig. 5). Per capita use was more accurately calculated for public water-supply systems for time intervals after 1970 than for earlier intervals because of available data from the WDNR, PSC, and USGS. For intervals 7 through 12 (1971-2005), per capita use in the Wisconsin nearfield model area (which included 196 public water-supply systems) ranged from 10 to $1,216 \mathrm{gal} / \mathrm{d}$ per person by community and year and averaged $134 \mathrm{gal} / \mathrm{d}$ per person; the median public-supply per capita use was $108 \mathrm{gal} / \mathrm{d}$ per person. This variability is mostly a function of the presence of large industrial water users being served by public supplies in older communities and a corresponding inflation of the per capita rate; most of the smaller per capita rates reflect water-supply systems that are in an initial development phase and service that is almost exclusively for residential use. Counties that included a community with an average per capita rate greater than $300 \mathrm{gal} / \mathrm{d}$ per person were within or immediately adjacent to the southeastern Wisconsin model subregion.

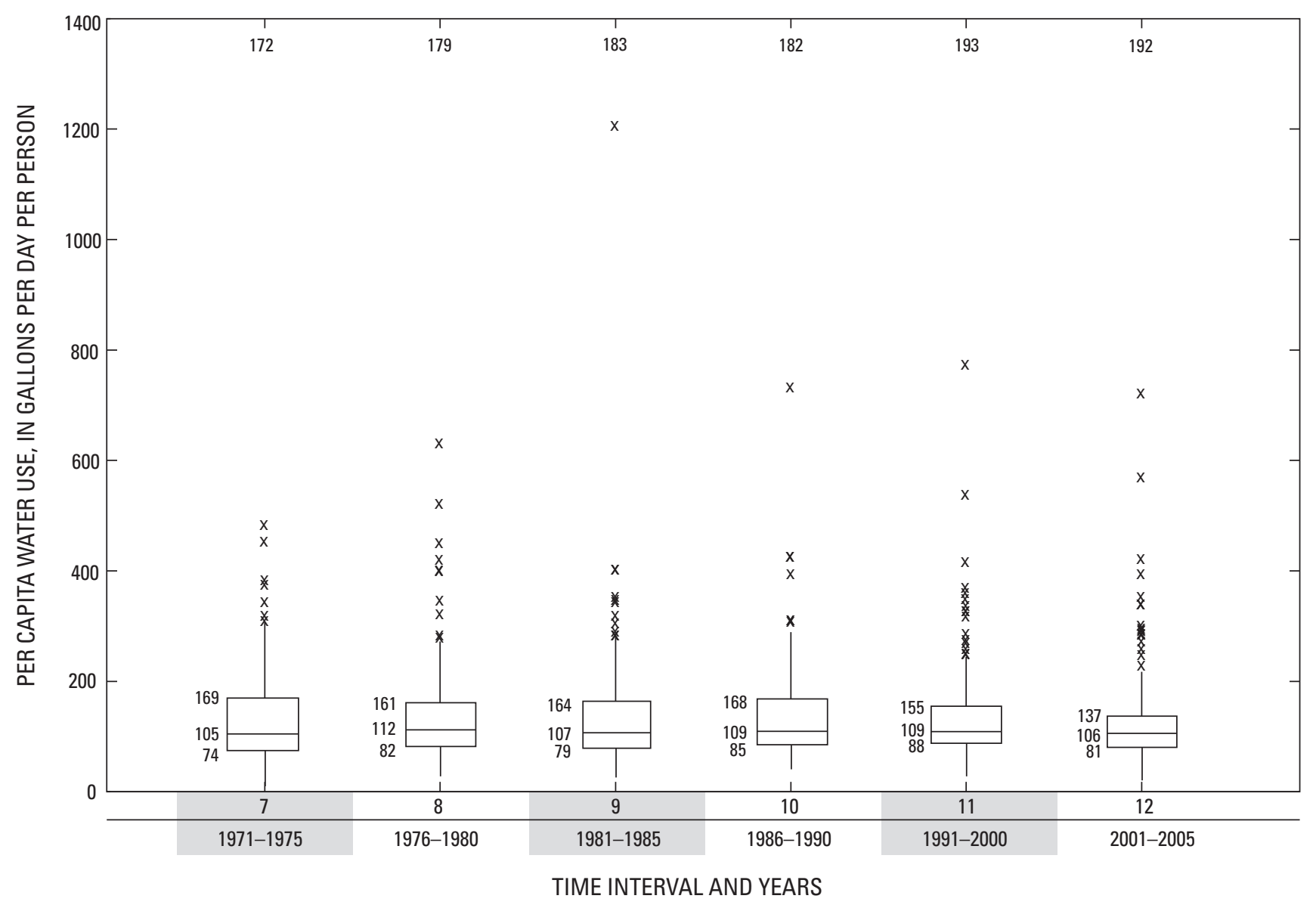

EXPLANATION

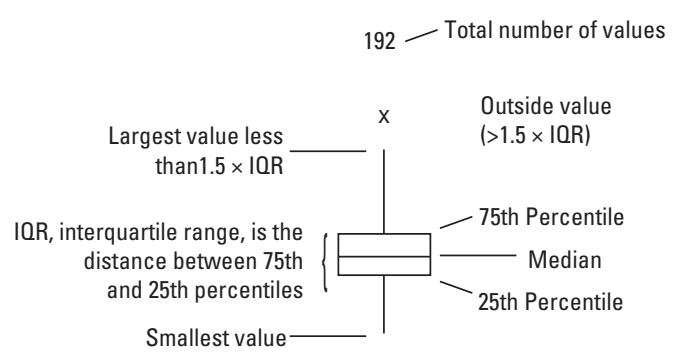

Figure 5. Public-supply per capita water use in the nearfield model area of Wisconsin, 1971-2005. 
Withdrawal rates found in datasets of previous studies (listed in the Wisconsin "Principal Data Sources" and "Additional Data Sources" sections) were compared and sometimes integrated with the withdrawal rates estimated in this study on the basis of per capita water-use estimates. Many withdrawal rates from previous groundwater modeling studies (Mandle and Kontis, 1992; Conlon, 1998; and Feinstein and others, 2004, 2005) were similar to the per capita use estimates developed for this study. Some data irregularities (for example, missing utilities, missing wells, combined rates for several active wells, and missing periods of pumping) were discovered and corrected from these previous groundwater models. These water-withdrawal estimates from previous studies typically were used as a guide to check the per capita use approach for estimating public-supply water use because, in some cases, more complete data were available to supplement the withdrawal data from those previous studies.

The date pumping was initiated for each community was determined by well-construction dates, by an inquiry, or by reference (Southeastern Wisconsin Regional Planning Commission, 2008). If a well was constructed during January through June, then it was assumed to be online during that same year. But if a well was constructed during July through December, then it was assumed to be online during the next year. The year a well went offline or inactive was determined from various well records, by inquiry, or by an approximation based on when a newer replacement well went online.

Withdrawal data for privately owned public water-supply utilities (defined in table 1) were limited. For these utilities, withdrawal estimates were held constant from when a well was installed through interval 12 (2001-5), unless otherwise noted. The SEWRPC planning report (Southeastern Wisconsin Regional Planning Commission, 2008) was used to confirm that privately owned public-supply wells with approved normal pumpage greater than $1 \mathrm{Mgal} / \mathrm{d}$ were included in the model dataset.

\section{Assumptions and Limitations of Wisconsin Public-Supply Data}

The public-supply groundwater withdrawals compiled and estimated for this study are based on the assumption that estimates provided by each facility are reasonably accurate and reliable from year to year and that aquifer determination and locations of withdrawals also are reasonably accurate. This study also assumed an upward trend in per capita use. These estimates could be missing water that is withdrawn by one water-supply system and sold to another area and possibly overrepresent withdrawals if only part of the community is served by the water-supply system. The water-use estimates include the assumption that the proportion of residential versus other uses is the same for each time interval for each community, as indicated by the calculated average per capita use. Thus, these estimates could be missing water distributed for publicly supplied industries or other uses that may have peaked before 1970 . Additional public supply might not be accounted for by private communities that withdrew water but were not identified. Therefore, public-supply water-use estimates prepared for Wisconsin likely underestimate some groundwater use, although the impact of this omission is small and will likely make little difference on the groundwater-flow model water levels in the primary area of interest (Daniel Feinstein, U.S. Geological Survey Wisconsin Water Science Center, oral commun., 2007).

The first known public-supply well in any particular system was assumed to have gone online when the watersupply system began supplying customers. In Wisconsin, this excludes any individual wells that a community might have operated before a public water-distribution network was established. It is possible that some historical water use is unaccounted for if early wells could not be verified. If there was no record of the location of the first water-supply well for a community, then the well was assumed to be in the community center. It is believed by the authors that most public-supply utilities were identified for the model water-use dataset, mainly from EWG, USEPA, WDNR, PSC, USGS, and SEWRPC sources.

\section{Industrial Water Use in Wisconsin}

Whereas many of Wisconsin's earliest industries required access to surface water for transport, energy production, or cooling purposes, many other key industries built upon the region's high-quality and abundant groundwater resources. Some of the industries that initially were predominant within this area were paper, metals, general manufacturing, tanning, and food-related industries such as canning, processing, dairying, and brewing. Although the majority of the withdrawals in the industrial category are specifically for industrial uses as defined in table 1, some commercial water uses have been combined into the industrial category in this report to best fit into the four-category scheme. For example, noncommunity system water uses, as defined in table 1, were considered commercial water uses and assigned to the industrial water-use category for this report. In Wisconsin, noncommunity systems include nursing homes, prisons, asylums, religious and academic institutions, airports, and campgrounds. Other commercial uses identified in the Wisconsin LMB model area using the most water were for such purposes of snowmaking or cooling (including air conditioning and refrigeration) or for such places as shopping centers; larger religious and health-care facilities; schools; resorts; clubhouses; railroads; and lodging. The majority of the industrial and commercial withdrawals now are in an area south and east of Portage County (fig. 3). But before 1940, they were concentrated almost exclusively within the nearfield model area. The earliest well records were associated with health institutions and railroads. Milwaukee County has the earliest known well records, and of those wells all but one are assumed to have been abandoned by the last model time interval. For the remainder of the report (including graphs and tables), the category called "industrial" for Wisconsin refers to combined industrial and commercial water uses unless noted otherwise. 
Overall, well and water-use information for 876 industrial and 526 commercial wells was compiled. Over the last halfcentury (intervals 5 through 12, or 1951-2005), industrial water use nearly doubled in the Wisconsin LMB model area (table 4). These industrial withdrawals increased from $0.41 \mathrm{Mgal} / \mathrm{d}$ during the first time interval (1864-1900) to $61.47 \mathrm{Mgal} / \mathrm{d}$ during the last interval (2001-5). The main reason for this increase was increasing water withdrawals in the farfield model subregion. Industrial water use, by itself, accounted for 86 to 95 percent of the combined total industrial water-use estimate in each time interval. Industrial water use by subregion is illustrated in figure $6 A$ (appendix 2). The industrial peak that occurred in interval 5 (1951-60) was concentrated within counties surrounding Lake Winnebago and adjacent to Green Bay.

Overall industrial water use in the Southeastern Wisconsin subregion has been relatively stable since interval 8 (1976-80). However, when the industrial component is considered separately from the combined industrial and commercial withdrawal estimate, water use for industry peaked during intervals 5 and 6 (1951-70) and has since declined, whereas commercial water use has increased over time. In fact, the remaining industries in Milwaukee County that were supplied by groundwater have either ceased use of groundwater or ceased operation entirely since the last time interval (2001-5). In Waukesha County, industrial water use represented nearly 100 percent of the category in interval 5 (1951-60), but it represented only about 76 percent of the category during the last time interval (2001-5) as the proportion of commercial water use increased. In general, growth in combined industrial water use has since occurred mainly in counties outside and along the nearfield boundary-in particular, Rock, Jefferson, and Portage Counties.

Most industrial withdrawals before interval 5 (1951-60) were from the Cambrian-Ordovician aquifer system, but since then well development has increased in the Quaternary and the Silurian-Devonian aquifer systems; as a result, withdrawals from these systems have increased (fig. 6B, appendix 2). Over the last seven time intervals (1951 through 2005), the average contributions for industrial withdrawals by aquifer system over the Wisconsin LMB model area were 27 percent from the Quaternary, 13 percent from the Silurian-Devonian, and 60 percent from the Cambrian-Ordovician. More recent well development appears to be occurring in unconfined unconsolidated material and deep confined bedrock aquifer types, whereas growth in withdrawals from shallow unconfined bedrock appears to be minor (fig. $6 C$, appendix 2).

\section{Additional Wisconsin Industrial Data Sources}

High-capacity well data came primarily from WDNR sources: Water Well Data CD-ROMs and GRN (Wisconsin Department of Natural Resources, 2005, 2006, 2007). Wateruse purpose was determined largely by well, owner, or operator name and type of property classification listed in the highcapacity well approval, but the purpose could also be determined sometimes from comments within the well-construction report. Most of the industrial and commercial wells within these data sources are coded by property class: "Industrial," "School," or "Miscellaneous." The WDNR property classification was evaluated and reassigned into the USGS water-use code standards (Mathey, 1990) with additional water-use site or purpose categorizations appended when possible. The "Well Name" field often included terms such as "shop well," "barn well," "factory well," "low-cap potable," "pond filling," "main supply," or "standby," which provided a way to identify the purpose of the well. Well names helped to omit wells where water use is likely negligible (defined for the model as a site withdrawal less than $1 \mathrm{Mgal} / \mathrm{yr}$ ) or too uncertain (for example, maintenance shops, rural churches, stores, offices, and small municipal airports). Several facility or owner names were queried through Internet resources to verify the most likely water-use purpose for a well.

Additional reports and previously existing groundwatermodel water-use datasets were incorporated to identify wells and withdrawal rates as previously described in the Wisconsin "Principal Data Sources" section. Construction dates were used to approximate the year the well became active. If a construction date was not available, then the date of the WDNR high-capacity well approval was substituted. If neither construction date nor approval date was available, then an Internet search was done to obtain, if possible, the year of facility establishment.

Certain well records for industrial and commercial uses were systematically removed from the final model water-use dataset. A record was removed if

1. it was determined that the well was never in production or had never been constructed;

2. data were missing for all three variables: well status, pump capacity, and past water withdrawal;

3. it was a test well for probable water yield;

4. it was a standby or backup well that was used infrequently or only known to be exercised;

5. it was a remediation, private residential, or fire-protection well;

6. a water-use estimate would be too uncertain or negligible (less than $1 \mathrm{Mgal} / \mathrm{yr}$ );

7. pump capacity was less than $50 \mathrm{gal} / \mathrm{min}$;

8. pump capacity was less than $70 \mathrm{gal} / \mathrm{min}$ and did not meet at least one of the following exceptions:

a. the water-use site has multiple wells with reported past water use having an annual sum greater than $1 \mathrm{Mgal} / \mathrm{yr}$; b. the well had only occasional past annual withdrawals greater than $1 \mathrm{Mgal} / \mathrm{yr}$;

c. the well was a fire-protection well for an industry but had reported past water use greater than $1 \mathrm{Mgal} / \mathrm{yr}$ (it was then assumed that the well was used for an additional purpose);

9. reported pump capacity was between 50 and $70 \mathrm{gal} / \mathrm{min}$ and the "normal pumpage" or "maximum pumpage" fields were left blank or were populated with the value of zero on the withdrawal approval;

10. no pump-capacity data were given, and the reported "normal pumpage" was less than $1,000 \mathrm{gal} / \mathrm{d}$. 


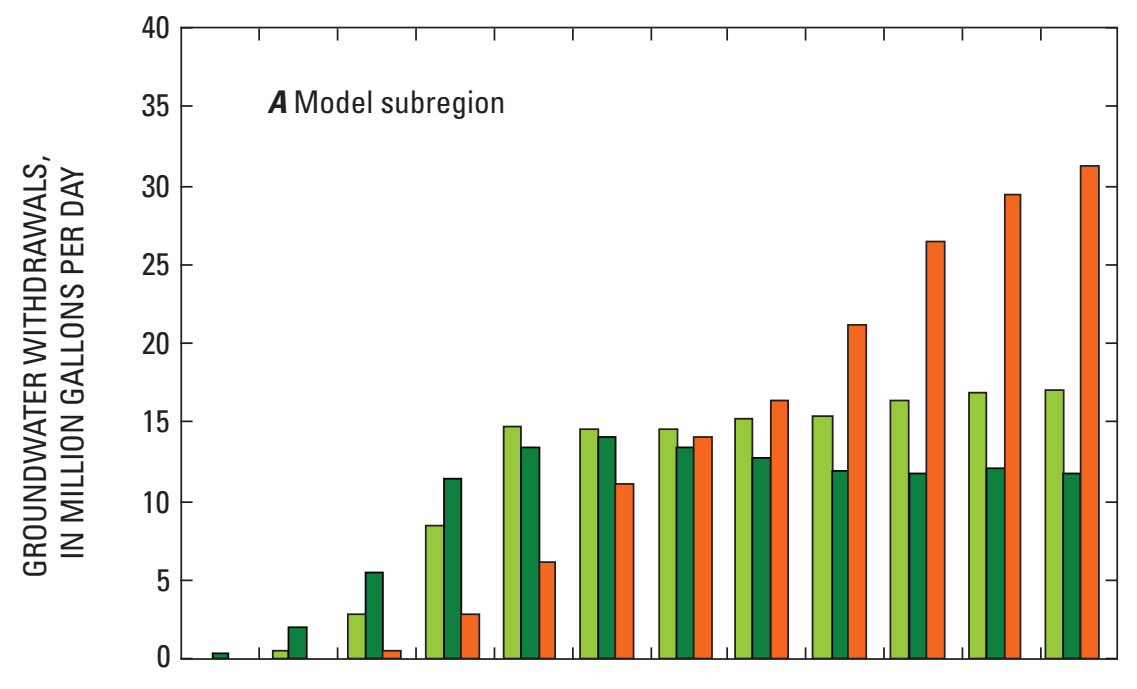

$\square$ Northeastern Wisconsin

$\square$ Southeastern Wisconsin

$\square$ Wisconsin farfield model area

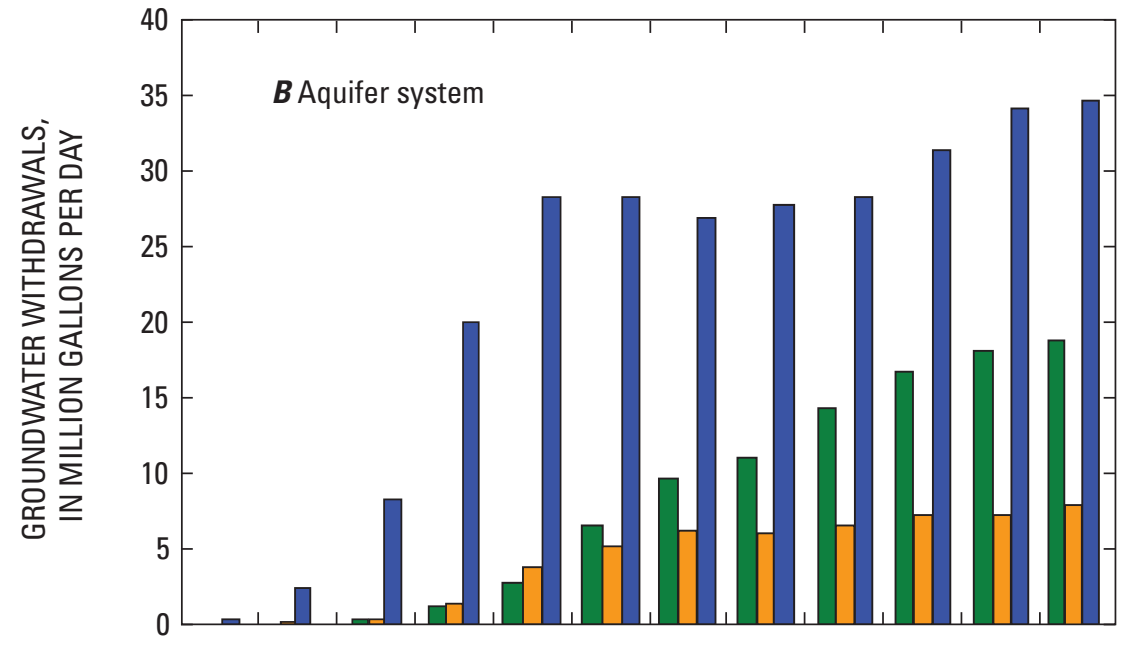

$\square$ Quaternary

$\square$ Silurian-Devonian

- Cambrian-Ordovician

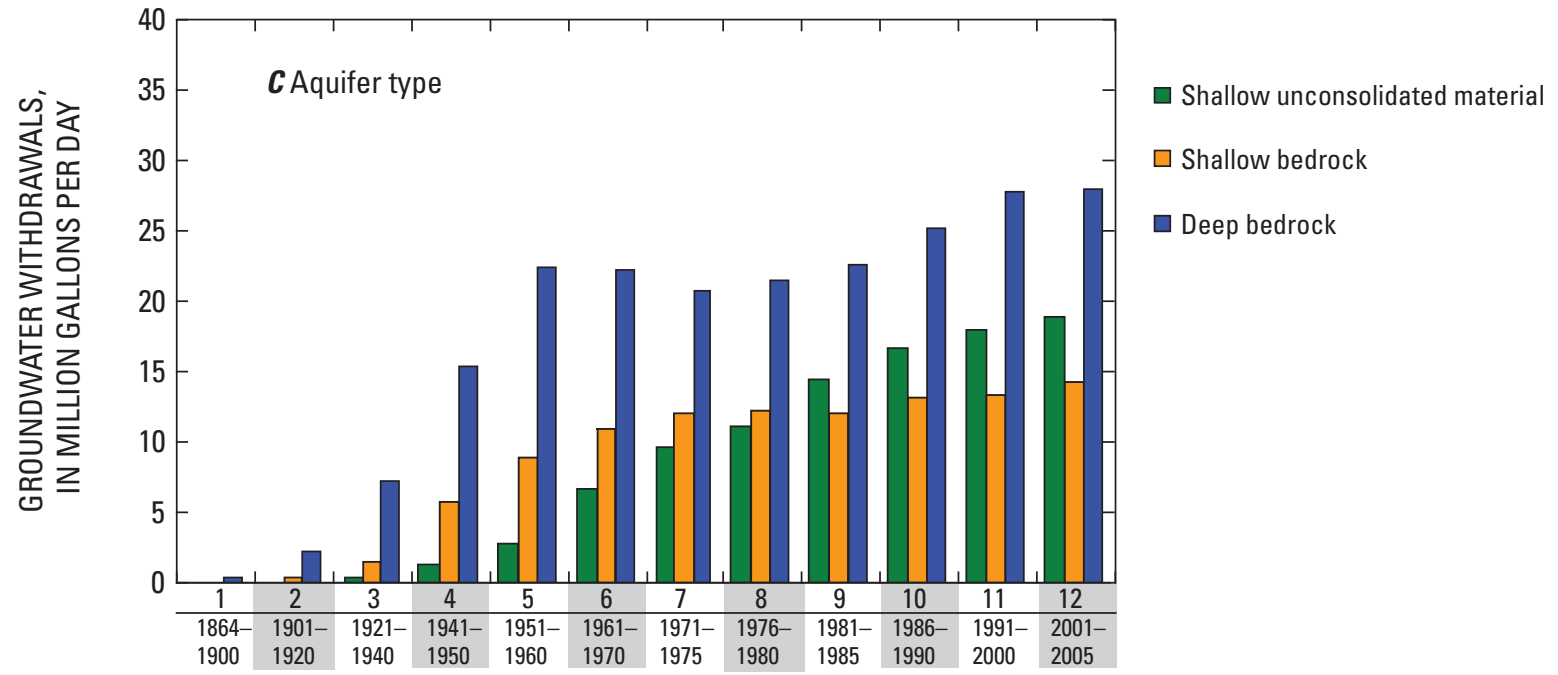

TIME INTERVAL AND YEARS

Figure 6. Industrial groundwater-use estimates in Wisconsin for the Lake Michigan Basin model by time interval and $A$, model subregion, $B$, aquifer system, and $C$, aquifer type. No withdrawals were determined for the mixed aquifer systems. The Jurassic-Mississippian aquifer system does not exist in Wisconsin. 


\section{Estimation Methods for Wisconsin Industrial and Commercial Withdrawals}

In the first estimation method used in this category, an overall average withdrawal value was calculated for each time interval for industrial (and commercial) wells in the Wisconsin LMB model area for which withdrawal data were available. Most available industrial withdrawal data were from the WDNR GRN database during intervals 8 through 10 (1976-90) and from other data sources (for example, past model water-use datasets) for earlier intervals. Typically, the withdrawal rate from the earliest reported rate was applied backwards to the year the well was constructed and forward to the next reported withdrawal rate (or overall averaged rate) of a later time interval. The latest withdrawal rate was applied forward through interval 12 (2001-5) or until the year when the well was assumed inactive or abandoned. There was one extra consideration applied only in this first method for wells with WDNR GRN data during intervals 8 through 10 . If it was known that a facility had closed during the last two intervals (1991-2005), then the withdrawal rate of the last fully active time interval was reduced in half and applied to the years until the facility closed in these last two intervals, under the assumption that the industrial facility was winding down.

Withdrawal data were then used to develop three other water-use estimation methods for industrial (and commercial) wells in the Wisconsin LMB model area with missing groundwater-withdrawal data.

In the second method, if a well record did not include past withdrawal data but similar wells from the same owner in the same county did report water-use data, then a similar withdrawal rate was assumed. If there was only one other well, then the same rate was substituted; but if there were more than one well, then the average of the reported withdrawal rates was applied.

In the third method, well records with reported water withdrawal, pump capacity, and approved normal daily pumpage data were used to create a withdrawal coefficientreferred to hereafter simply as a "coefficient"- to use for well records that reported pump capacity and approved normal daily pumpage but no water-withdrawal data. A coefficient was derived by sorting records of specific water-use types with the required information, dividing reported withdrawal by normal daily pumpage, and then calculating the average and median values for the water-use type. For the coefficient, the average was chosen if there were fewer than five records, and the median was chosen if there were five or more records because the median is more representative when outliers (unusual, extreme values) are in a dataset. An estimated withdrawal value was generated by multiplying the coefficient for a specific water-use type by the approved normal pumpage, then multiplying that number by the number of days that well was assumed to be in operation. This method was applied rather than directly using the approved normal daily pumpage because reported daily pumpage and pump capacity are more often artifacts of pump design and might not accurately reflect water withdrawals from a well (specifically, pumps rarely run daily at full capacity and at a constant rate).

A final, fourth method was needed for well records without available data pertaining to water use, pump capacity, and normal pumpage. This water-use estimation method used existing withdrawal data for wells with similar water-use purposes to determine a baseline withdrawal amount - referred to hereafter as a "withdrawal default." Two main data sources were used to develop the withdrawal defaults: the Wisconsin withdrawal data in the WDNR GRN (1976-90) and the Minnesota withdrawal data in MNDNR SWUDS (1988-2005). The defaults were calculated averages and medians of withdrawals for wells with similar water-use purposes. The averages and medians from Wisconsin withdrawal data were compared with the averages and medians from Minnesota withdrawal data. The values between the two states and time ranges were quite comparable for each water-use purpose analyzed, but because Minnesota data were more current and complete, the Minnesota median values for groundwater withdrawals were given priority when choosing a final withdrawal default. For some industrial (and commercial) wells of certain water-use purposes (those assumed to withdraw greater than 1 $\mathrm{Mgal} / \mathrm{d}$ ), withdrawal data were scarce or nonexistent; for these wells, a minimal withdrawal default of $1 \mathrm{Mgal} / \mathrm{d}$ was applied to account for an active site with uncertain withdrawal. Figure 7 and table 8 present further details about the procedures used in producing industrial (and commercial) water-use estimates in Wisconsin.

In general, well-construction information, well status, and other hydrogeologic-unit information in former modeling datasets were integrated into the withdrawal estimates. A few well records were missing information on well or casing depth, which is needed for hydrogeologic-unit (model-layer) determination. For such wells, an estimate based on the average depth of other wells in the county by the same owner was substituted. If that was not possible, then the average of other wells with the same water-use purpose was applied; otherwise, either (1) an overall average depth for an industrial well (or for a commercial well) was applied on the basis of all reported depth information in the county, or (2) the well-depth data field was left blank and the well simply assigned to the most likely aquifer system. 


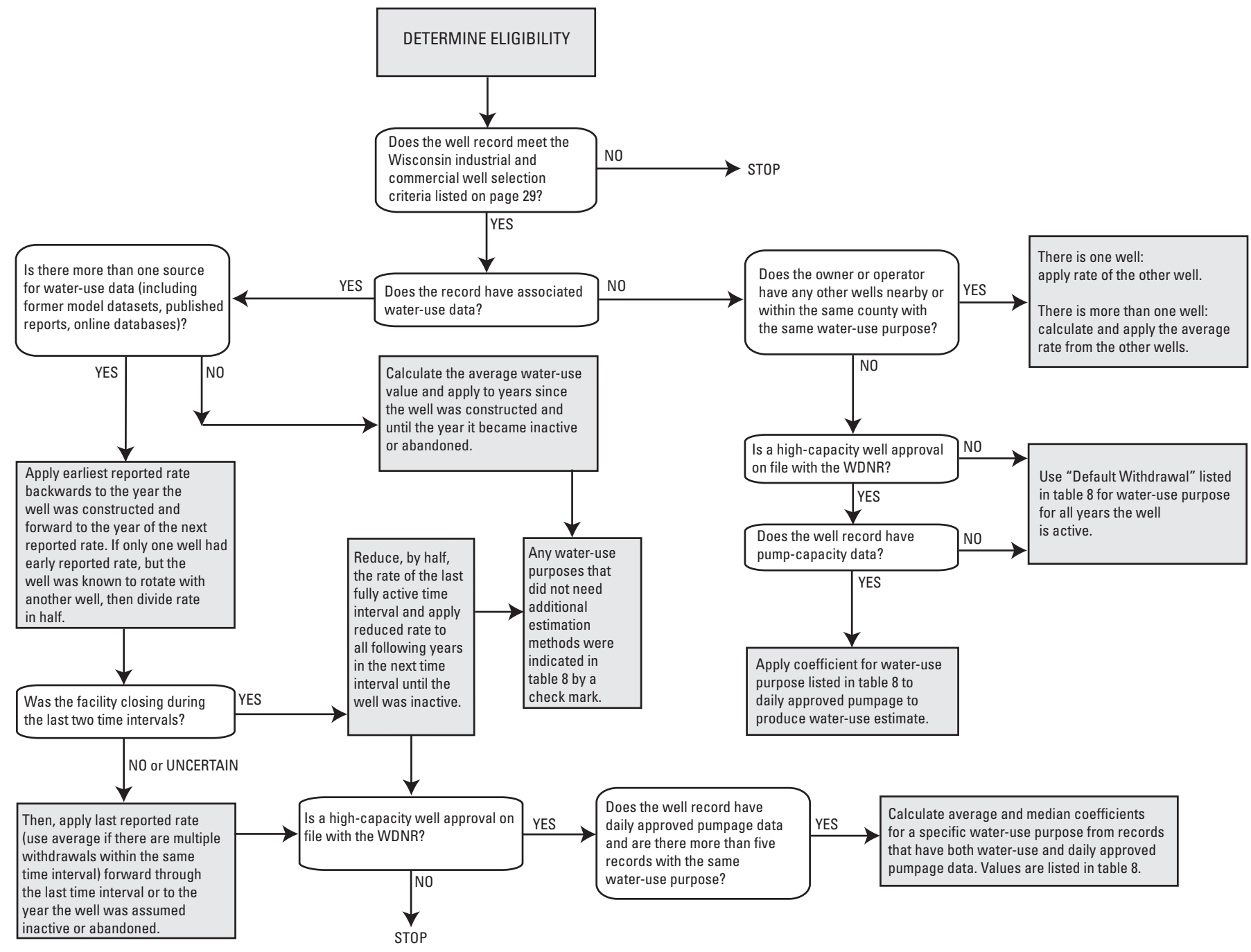

Figure 7. Flow chart showing the approach and methods applied for estimating industrial and commercial groundwater withdrawals in Wisconsin. 
Table 8. Groundwater-withdrawal estimation methods for industrial water use in Wisconsin, by water-use purpose. (Industrial water use is defined in table 1 and for Wisconsin includes some commercial water uses. Well records must meet well-selection criteria defined on page $\mathbf{2 9}$ prior to using this table. See figure 7 flow chart for water-use estimation process.)

[Mgal/yr, million gallons per year; N, normal daily pumpage reported on high-capacity well approval; $\sqrt{ }$, no estimate needed; --, estimate not determined]

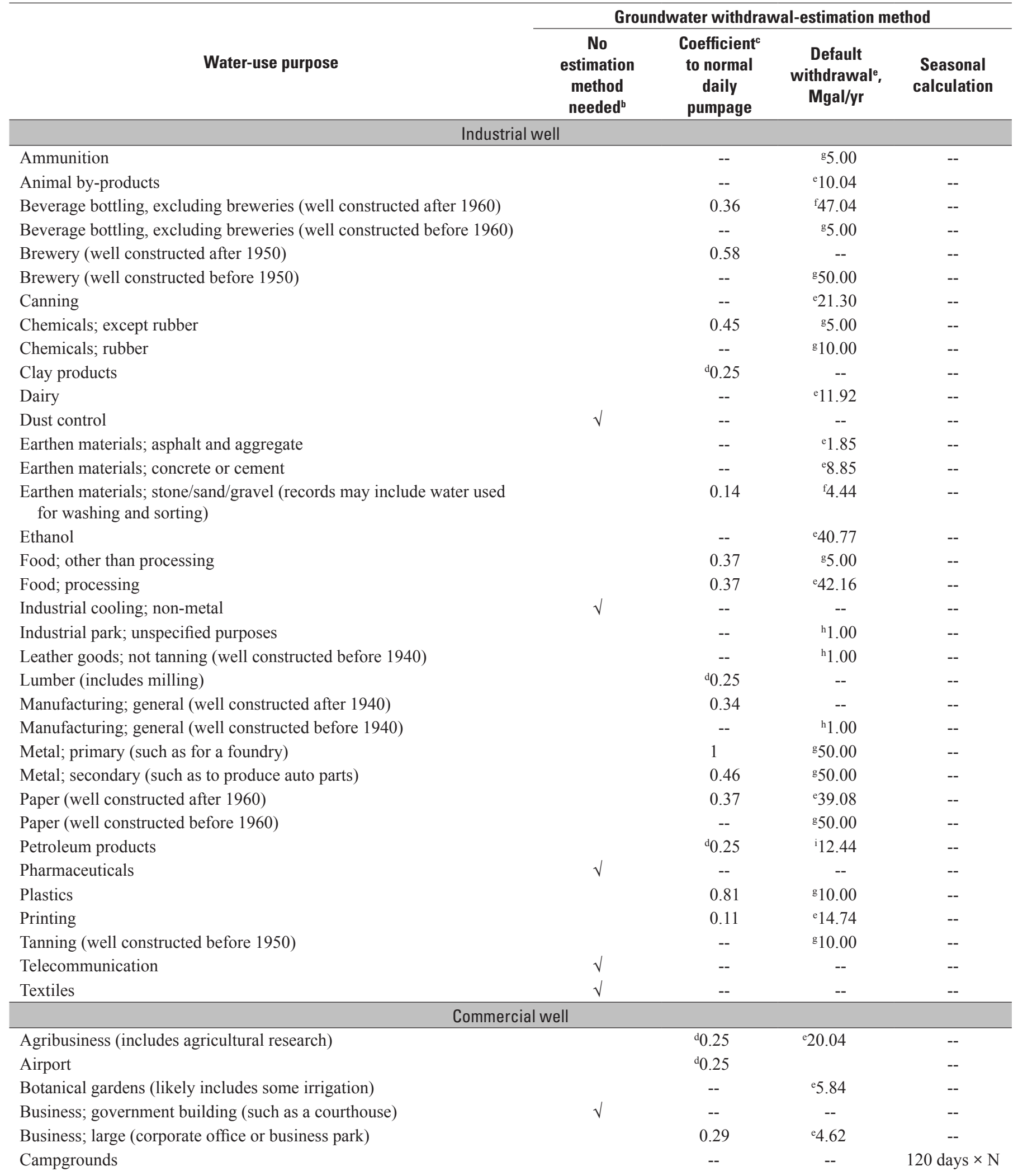


Table 8. Groundwater-withdrawal estimation methods for industrial water use in Wisconsin, by water-use purpose. (Industrial water use is defined in table 1 and for Wisconsin includes some commercial water uses. Well records must meet well-selection criteria defined on page $\mathbf{2 9}$ prior to using this table. See figure 7 flow chart for water-use estimation process.)—Continued

[Mgal/yr, million gallons per year; N, normal daily pumpage reported on high-capacity well approval; $\sqrt{ }$, no estimate needed; --, estimate not determined]

\begin{tabular}{|c|c|c|c|c|}
\hline \multirow[b]{2}{*}{ Water-use purpose } & \multicolumn{4}{|c|}{ Groundwater withdrawal-estimation method } \\
\hline & $\begin{array}{c}\text { No } \\
\text { estimation } \\
\text { method } \\
\text { needed }^{\text {b }}\end{array}$ & $\begin{array}{l}\text { Coefficient }^{\mathrm{c}} \\
\text { to normal } \\
\text { daily } \\
\text { pumpage }\end{array}$ & $\begin{array}{c}\text { Default } \\
\text { withdrawale, } \\
\text { Mgal/yr }\end{array}$ & $\begin{array}{l}\text { Seasonal } \\
\text { calculation }\end{array}$ \\
\hline \multicolumn{5}{|c|}{ Commercial well-Continued } \\
\hline Car wash & & $0.25^{\mathrm{d}}$ & & -- \\
\hline Casino & & $0.25^{\mathrm{d}}$ & $5.00^{\mathrm{g}}$ & -- \\
\hline Cemetery; service or administrative building & $\sqrt{ }$ & -- & -- & -- \\
\hline Clubhouse (typically at a country club or golf course) & & 0.35 & & -- \\
\hline Cold storage & & 0.43 & $14.75^{\mathrm{e}}$ & -- \\
\hline Community center & & $0.25^{\mathrm{d}}$ & & -- \\
\hline Conference center & & $0.25^{\mathrm{d}}$ & & -- \\
\hline $\begin{array}{l}\text { Construction (well constructed after } 1960 \text { and has a pump capacity } \\
\text { more than } 200 \text { gallons per minute) }\end{array}$ & & -- & $2.68^{\mathrm{e}}$ & -- \\
\hline Construction (well constructed before 1960) & & & $1.00^{\mathrm{h}}$ & -- \\
\hline Cooling; other facility (e.g. restaurant, theater) & & 0.34 & $5.00^{\mathrm{g}}$ & -- \\
\hline Cooling; school or large business & & 0.34 & $11.24^{\mathrm{f}}$ & -- \\
\hline Correction facility & & $0.25^{\mathrm{d}}$ & $1.00^{\mathrm{h}}$ & -- \\
\hline Health institution (includes hospitals) & & 0.26 & $1.00^{\mathrm{h}}$ & -- \\
\hline Lodging & & 0.56 & $1.00^{\mathrm{h}}$ & -- \\
\hline Museum & & $0.25^{\mathrm{d}}$ & & -- \\
\hline Park \& recreation & & 0.17 & & -- \\
\hline Railroad (withdrawal prior to 1960 ) & & -- & $5.00^{\mathrm{g}}$ & -- \\
\hline Religious institution (larger only) & & & $3.20^{\mathrm{e}}$ & -- \\
\hline Research facility (includes most laboratories) & & & $1.95^{\mathrm{e}}$ & -- \\
\hline Resort & & 0.45 & & -- \\
\hline Restaurant & & & $1.00^{\mathrm{h}}$ & -- \\
\hline School $^{a}$ (well constructed before 1940) & & & $1.00^{\mathrm{h}}$ & -- \\
\hline School $^{\text {a }}$ (well constructed after 1940) & & & $2.03^{\mathrm{e}}$ & -- \\
\hline Shopping center & & 0.21 & $1.00^{\mathrm{h}}$ & -- \\
\hline Snowmaking & & & $12.44^{\mathrm{e}}$ & -- \\
\hline Unspecified commercial high-capacity use & & $0.25^{\mathrm{d}}$ & $1.00^{\mathrm{h}}$ & -- \\
\hline Waterpark & & -- & -- & 120 days $\times \mathrm{N}$ \\
\hline Wayside (only along Interstate highways) & $\sqrt{ }$ & -- & -- & - \\
\hline Zoological garden & $\sqrt{ }$ & -- & -- & -- \\
\hline
\end{tabular}

${ }^{a}$ A well for a school was included if it met well-selection criteria outlined in the report; therefore, most small rural schools were excluded.

${ }^{\mathrm{b}}$ Water withdrawal data were available for all wells identified with this water-use purpose.

${ }^{\mathrm{c}}$ Coefficient was calculated from available data (water withdrawal, pump capacity, and approved normal daily pumpage) reported by the Wisconsin Department of Natural Resources $(2005,2006,2007)$ unless noted otherwise.

${ }^{\mathrm{d}}$ Default coefficient of 0.25 applied to normal permitted pumpage approved for an industrial or commercial well that likely withdrew over $1 \mathrm{Mgal} / \mathrm{yr}$. The coefficient was generalized to be about a quarter of the approved pumpage amounts. This generalization was based on 588 industrial water-use records that had water-use data and approved normal and maximum daily pumpage amounts. The calculated median coefficients are 0.33 based on normal daily pumpage and 0.21 based on maximum daily pumpage.

${ }^{\mathrm{e}}$ Calculated median from records in the Wisconsin water-use dataset with available withdrawal data, 1976-90; original data source is from the Wisconsin Department of Natural Resources (2005).

${ }^{\mathrm{f}}$ Calculated median from Minnesota water-use data, 1988-2005, with the exception of cooling (applied for schools and large businesses) which was based on 2001-5 data (Minnesota Department of Natural Resources, 2007).

${ }^{\mathrm{g}}$ A value greater than the minimum withdrawal was assumed. Most estimates requiring this default were for wells in earlier time periods, typically before 1960.

${ }^{\mathrm{h}}$ Minimum default withdrawal value applied to a well that likely withdrew more than $1 \mathrm{Mgal} / \mathrm{yr}$.

${ }^{i}$ Based on average daily water demand of 136,288 gallons per day (Vickers, 2001) 
Assumptions and Limitations of Wisconsin Industrial and Commercial Data

Some water-use data were not available or were excluded for other reasons. In the earlier time intervals, various commercial establishments and industries common throughout the Wisconsin part of the study area - such as those alluded to in old industry listings, historical documents, books and advertisements - were not accounted for because of uncertainty in the water-supply source (groundwater or surface water, publicly supplied or self-supplied). Some facilities are not required to have high-capacity well approvals or did not have a well listed in the state-specific well-construction or geologic databases, so underestimation may have occurred because withdrawals at such facilities would not be accounted for. The selection criteria also eliminated some water-use sites whose water-use purposes were highly uncertain. The degree in which water-use withdrawals were missed can vary by time interval. It is likely that underestimates were more associated with the earlier intervals than the later intervals.

Although most of the withdrawals reported, especially from the WDNR GRN database, were assumed to be reasonable, some of the values or estimates in any of the data sources might have been incorrect. The well status might have been wrong. In addition, changes in facility operations, such as ceasing operation or changing to a surface-water or purchased-water source, might not have been reflected in the well records.

For records with water use estimated by the application of a coefficient (as described in the above section called "Industrial Estimation Methods"), it was assumed reasonable to use pump-capacity data as an indicator to coarsely distinguish one facility from another with regard to variations in operation size, water demand, and spatial variation of aquifer properties affecting water availability. All but two of the industrial (and commercial) water-use coefficients were applied year round and did not take into account possible changes in operation, water requirements, or seasonality. The exceptions were for campgrounds and water parks, where summer-only operation was assumed for 120 days (table 8). For other seasonal places of water use, such as at schools or snowmaking establishments, the coefficient approach was not applied but an annual withdrawal default was used instead.

Furthermore, the following assumptions were applied and limitations were considered when using the Wisconsin industrial and commercial water-use records. If normal daily pumpage in the withdrawal approval was not reported, then half the maximum daily pumpage was used, if available. The data field called "Well Name" of WDNR data sources was searched to identify records with the terms "abandoned" or "replaced by" in order to modify the well status field. If no status information was available, then the well was assumed active for 20 years. Source errors were adjusted as the data were analyzed, but some errors might have been missed. Additional interpretive errors in coding and water-use categorization are possible. More often than not, water-withdrawal estimates from previous studies served as a guide or check to the water-use estimates produced for this study, with the exception that Conlon's estimates (1998) were largely accepted or revised for years prior to 1970 for industrial high-capacity well withdrawals in northeastern Wisconsin.

\section{Irrigation Water Use in Wisconsin}

In Wisconsin, irrigation well records were grouped by three irrigation water-use purposes: principal crop, specialty agriculture, and other irrigation. As used in this study, principal crop irrigation refers to water applied to the growing of grains, grasses, legumes, and vegetables; crops that are typical for Wisconsin include corn, hay, soybeans, and several types of vegetables (for example, potatoes, tomatoes, snap peas, beans, and cabbage). Specialty agriculture irrigation refers to water applied to assist with the growing of specialty agricultural products typically found at tree farms, orchards, nurseries, and greenhouses, which includes the growing of berries, sod, mint, ginseng, commercial seeds, flowers, and mushrooms. Other irrigation refers to water used at athletic fields, cemeteries, and golf courses, or for other landscaping needs. The majority of Wisconsin's irrigation water use has been for agricultural purposes, predominantly principal crop irrigation.

Estimated groundwater withdrawals increased from 0 $\mathrm{Mgal} / \mathrm{d}$ for the first time interval to $159.70 \mathrm{Mgal} / \mathrm{d}$ for the last interval (table 4). Water-use estimates are significantly lower before interval 6 (1961-70) because of (1) a lack of data, (2) predominance of dry farming (precipitation-derived water input), and (3) lack of adequate water-well pump and irrigation technology. The few wells that were constructed before 1941 were for various sites such as a cemetery, country club, and commercial seed farm. Most irrigation in the Wisconsin model area remained minimal until interval 6 (1961-70), when groundwater well-pump technology advanced and center-pivot irrigation systems were developed (U.S. Department of Agriculture, 1955); since then, irrigation has increased by nearly 4 times (appendix 2). Growth of irrigation, especially after 1970 , can be attributed in part to legislative changes in water-resource management (Dawson, 2003), response to severe droughts such as those in 1976-77 and 1987-88 (Paulson and others, 1991; Wisconsin State Climatology Office, 2009), further development in irrigation technology, and farming decisions such as installation of backup irrigation systems to cope with drought and to increase crop yields (Paul Mitchell, University of Wisconsin-Madison, oral commun., 2008). The likely trend of increased agricultural irrigation water use corresponds to increased irrigation acreage, number of farms irrigating, reported number of irrigation wells used on farms (U.S. Department of Commerce-Bureau of the Census, 1977, 1982, 1990a, 1990b; U.S. Department of Agriculture, 1995, 1999b, 2004b), number of high-capacity well withdrawals seeking approval from the WDNR for irrigation, and increased water-application rates (Wisconsin Department of Natural Resources, 2006, 2007). Other irrigation uses made up approximately 1.6 percent (or $0.59 \mathrm{Mgal} / \mathrm{d}$ ) of the total irrigation withdrawal in interval 6 
(1961-70) and increased to 3.7 percent (or $5.89 \mathrm{Mgal} / \mathrm{d}$ ) by the last time interval (interval 12). Total irrigation in recent time intervals amounted to about a third of the total withdrawal in the Wisconsin LMB model area (table 4).

Overall, more irrigation water use occurred within the farfield model area than in the nearfield model area; and inside the nearfield, more irrigation water use occurred within the Northeastern Wisconsin subregion than in the Southeastern Wisconsin subregion (fig. 8A). In summary, 14 percent (509 records) of the 3,637 irrigation wells identified were within the nearfield model area, of which 434 records were active in the last time interval. Irrigation water use by aquifer system in the Wisconsin model area is shown in figure $8 B$, and data are listed in appendix 2. The majority (or 84 percent) of the water used for irrigation since 1961 (interval 6) came from the Quaternary aquifer system, whereas the Silurian-Devonian aquifer system contributed 3.5 percent and the Cambrian-Ordovician aquifer system contributed 12.5 percent. Development in the farfield model area (primarily in Portage, Waushara, Wood, and Juneau Counties in central Wisconsin) led to an increased contribution from the Cambrian-Ordovician aquifer system in later time intervals. Likewise, as shown in figure $8 C$ (data in appendix 2), most irrigation withdrawals were from the unconfined unconsolidated material aquifer type, whereas the remainder was split about equally between the shallow unconfined bedrock and deep confined bedrock aquifer types.

\section{Additional Wisconsin Irrigation Data Sources}

Several additional sources were used to produce the irrigation water-use estimates in Wisconsin besides those previously listed under the earlier Wisconsin "Principal Data Sources" section. A report summarizing Wisconsin's first 100 years in agriculture (1848-1948) included some information about early irrigation and location of crops grown (Wisconsin Department of Agriculture, 1948); however, most data about irrigation came from the U.S. Department of Agriculture (USDA) Census of Agriculture series. The earliest census reporting on agricultural irrigation in Wisconsin was for 1929 within the 1940 Census of Agriculture (U.S. Department of Commerce-Bureau of the Census, 1942). The first non-zero values for irrigation data by county appeared in the 1950 Census of Agriculture for 1944 and 1949 (U.S. Department of Commerce-Bureau of the Census, 1952). Additional data for irrigated acreage were collected for 1954, 1959, 1969, 1974, 1978, 1987, 1992, 1997, and 2002 (U.S. Department of Commerce-Bureau of the Census, 1956, 1961, 1972, 1977, 1982, 1990a; U.S. Department of Agriculture, 1995, 1999a, 2004a). Both the 1969 and 1974 censuses include associated water-use data and report the number of farms that irrigate. Digital orthoimagery from the USGS (various dates) and National Agriculture Imagery Program (NAIP) imagery from the U.S. Department of Agriculture-Farm Service Agency-Aerial Photography Field Office (2006) were acquired for various years during the last two time intervals (1991-2005) and were used when status or location of a currently approved irrigation well was in question. The Farm and Ranch Irrigation Survey was obtained for the years 1988, 1998, and 2003, which span the last three time intervals (U.S. Department of Commerce-Bureau of the Census, 1990b; U.S. Department of Agriculture, 1999b, 2004b). Although these censuses summarize the entire State of Wisconsin, they showed the quantity of groundwater applied had increased 36 percent over intervals 10-12 (1986-2005), whereas the model water-use estimates reflect a 24-percent increase over this same time period within the entire Wisconsin LMB model area.

\section{Estimation Methods for Wisconsin Irrigation Withdrawals}

A well inventory from source datasets was prepared to define irrigation water-use purpose, identify wells that were replaced, assign the year the well became active, and determine the hydrogeologic unit to which the well was open. All irrigation wells listed in GWSI, wiscLITH, or previous model datasets were used. Only irrigation wells listed in the WDNR high-capacity well approval database that met the pumpcapacity criteria outlined in the industrial water-use section were included. Records were sorted by similar water-use purposes, and overall averages and medians were calculated for records with associated water-use data. Preference was given to water-use data associated with the record by using those data if available. If data were unavailable, then an estimation method was applied. If water-use data associated with the record were available for only a few years, the average withdrawal spanning all available years was applied backwards to the year the well was constructed and forward to the year the well became inactive or was sealed.

The majority of the irrigation records that were identified were for principal crop irrigation and were collected from the GRN database for intervals 8, 9, and 10 (1976-90). The overall average from 1976 to 1990 for principal crop irrigation is $19.63 \mathrm{Mgal} / \mathrm{yr}(0.054 \mathrm{Mgal} / \mathrm{d}$,) and the median is 16.41 $\mathrm{Mgal} / \mathrm{yr}(0.045 \mathrm{Mgal} / \mathrm{d})$. For irrigation water-use purposes with limited or missing water-use data, a second approach based on withdrawal defaults was used. Most of these default water-use values were determined by examining more than 5,000 waterwell permits from Minnesota (MNDNR WAPP) for irrigation records with reported withdrawals. In general, the averages and medians calculated for withdrawals for the few comparable irrigation water-use purposes (golf course, principal crop, and berry growing) in Wisconsin were similar to those in Minnesota. For example, of the 4,274 MNDNR water-use permits coded for principal crop irrigation, the average withdrawal from 1988 to 2005 was $17.97 \mathrm{Mgal} / \mathrm{yr}(0.049 \mathrm{Mgal} / \mathrm{d})$ and the median withdrawal was $19.45 \mathrm{Mgal} / \mathrm{yr}(0.053 \mathrm{Mgal} / \mathrm{d})$. When determining the irrigation withdrawal default for Wisconsin, typically the median was chosen when there were more than five records because the average tends to be distorted by outliers. For principal crop irrigation, however, the median withdrawal in Minnesota was very similar to the Wisconsin average for 1976-1990; therefore, the Wisconsin average was chosen instead of the median. Irrigation wells for purposes other than principal crop irrigation without reported water use in any time interval were assigned a default value listed in table 9 . 

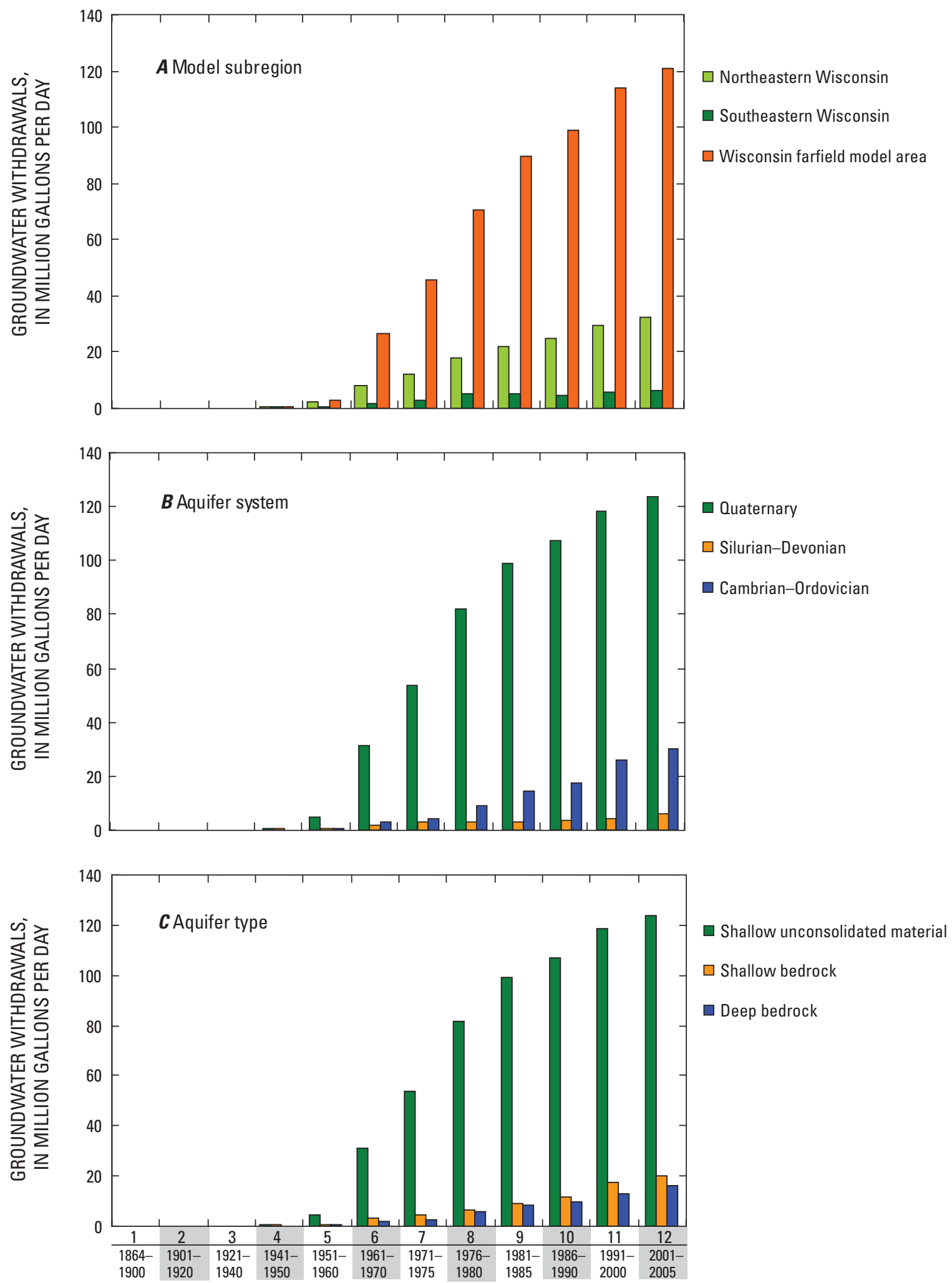

TIME INTERVAL AND YEARS

Figure 8. Irrigation groundwater-use estimates in Wisconsin for the Lake Michigan Basin model by time interval and $A$, model subregion, $B$, aquifer system, and $C$, aquifer type. The Jurassic-Mississippian aquifer system does not exist in Wisconsin. 
Table 9. Irrigation default groundwater-use values used in Wisconsin, by purpose.

[Mgal/yr, million gallons per year; MNDNR WAPP, Minnesota Department of Natural Resources Water Appropriations Permit Program; IL, Illinois; MN, Minnesota; WI, Wisconsin]

\begin{tabular}{|c|c|c|}
\hline $\begin{array}{l}\text { Irrigation water-use } \\
\text { purpose }\end{array}$ & $\begin{array}{l}\text { Default groundwater- } \\
\text { withdrawal value that } \\
\text { was assigned, Mgal/yr }\end{array}$ & Water-use estimation method \\
\hline \multicolumn{3}{|r|}{ Well-withdrawal estimate } \\
\hline Orchard & 2.33 & $\begin{array}{l}\text { Median withdrawal based on MNDNR WAPP data for wells with same water } \\
\text { purpose }\end{array}$ \\
\hline Nursery & 2.65 & $\begin{array}{l}\text { Median withdrawal based on MNDNR WAPP data for wells with same water } \\
\text { purpose }\end{array}$ \\
\hline Flower growers & 2.65 & Assumed similar water use to a nursery withdrawal \\
\hline Greenhouse & 2.65 & Assumed similar water use to a nursery withdrawal \\
\hline Evergreen farms & 2.65 & Assumed similar water use to a nursery withdrawal \\
\hline Seed farms & 2.65 & Assumed similar water use to a nursery withdrawal \\
\hline Athletic fields & 3.98 & $\begin{array}{l}\text { Median withdrawal based on MNDNR WAPP data for wells with same water } \\
\text { purpose }\end{array}$ \\
\hline Landscaping & 3.98 & $\begin{array}{l}\text { Median withdrawal based on MNDNR WAPP data for wells with same water } \\
\text { purpose }\end{array}$ \\
\hline Sod & 6.46 & $\begin{array}{l}\text { Median withdrawal based on MNDNR WAPP data for wells with same water } \\
\text { purpose }\end{array}$ \\
\hline Cemetery & 6.59 & $\begin{array}{l}\text { Median withdrawal based on MNDNR WAPP data for wells with same water } \\
\text { purpose }\end{array}$ \\
\hline $\begin{array}{l}\text { Berries (includes } \\
\text { cranberries) }\end{array}$ & 9.54 & $\begin{array}{l}\text { Average withdrawal from all available IL, MN, and WI records with this water- } \\
\text { use purpose }\end{array}$ \\
\hline Principal crop ${ }^{\mathrm{a}}$ & 19.63 & $\begin{array}{l}\text { Average withdrawal (1976-1990) for wells in Wisconsin with same water-use } \\
\text { purpose }\end{array}$ \\
\hline Unspecified other & variable & $\begin{array}{l}\text { Calculation based on } 5 \text { days per month for } 4 \text { growing season months at normal } \\
\text { pumpage rate }\end{array}$ \\
\hline Other specialty foods ${ }^{\mathrm{b}}$ & variable & $\begin{array}{l}\text { Calculation based on } 5 \text { days per month for } 4 \text { growing season months at normal } \\
\text { pumpage rate }\end{array}$ \\
\hline \multicolumn{3}{|r|}{ Site-withdrawal estimate } \\
\hline Golf course $^{c}$ & 5 & Based on 9 holes or 15 acres of irrigated acreage \\
\hline Golf course & 10 & Based on 18 holes or 30 acres of irrigated acreage \\
\hline Golf course & 15 & Based on 27 holes or 45 acres of irrigated acreage \\
\hline Golf course & 20 & Based on 36 holes or 60 acres of irrigated acreage \\
\hline Golf course & 25 & Based on 45 holes or 75 acres of irrigated acreage \\
\hline
\end{tabular}

Estimates of groundwater used for irrigation by golf courses were prepared previously for the 2005 "Water Use in Wisconsin" compilation (Buchwald, 2009). Only golf courses identified as having at least one high-capacity water well for greens and fairway maintenance or pond-filling were included. The preferred estimate was the average of the associated withdrawal data for a well record; but if no withdrawal data were reported, then a site withdrawal estimate listed in table 9 was substituted. For golf courses with multiple wells but no withdrawal data, the site withdrawal estimate was divided equally among the wells. If withdrawal data were available for only some wells at the site, then those withdrawals were subtotaled and subtracted from the total site withdrawal estimate. This difference was then split equally among the remaining wells with no withdrawal data. The water-use defaults for golf course irrigation are based on the number of holes or irrigated greens and fairway acreage; these values reflect a composite of Wisconsin courses (Tom Schwab, O.J. Noer Turf Grass Research \& Education Facility, oral commun., 2001).

An independent water-use estimation method was developed to evaluate the well-based dataset against irrigation data reported by the USDA in the Census of Agriculture. This comparison was done only for counties that were more than 75 percent within the Wisconsin LMB model area. The 
evaluation assessed whether agricultural irrigation by county was likely underestimated or overestimated for each time interval by comparing the well-inventory method against an estimate that incorporates a water application rate and reported irrigated acreage. Water-use data were included only in the 1969 and 1974 Census of Agriculture reports, and the reported values combined both surface-water and groundwater sources; however, only groundwater use was needed for the model water-use dataset. Therefore, a generalization of 80 percent groundwater based on proportions reported in the 1988, 1998 and 2002 USDA Farm and Ranch Irrigation Surveys was applied to the total use reported in 1969 and 1974. The resulting estimated median groundwater application rate for 1969 is $385(\mathrm{gal} / \mathrm{d}) / \mathrm{acre}$ and for 1974 is 465 (gal/d)/acre.

The approximated 1969 water-application rate was used as the coefficient to irrigated acreage for model time intervals before interval 7, and the approximated 1974 waterapplication rate was used for time intervals including and after interval 7 (1971-75). If the difference between the censusbased and well-based water-use estimates was greater than 20 percent for a county, then the well records for that county were reevaluated and revised. Three types of revisions were made:

1. Recode water-use purpose. - It was found that some records were assigned the wrong water-use purpose; for example, when an irrigation well was coded as a golf course well but should have been characterized as a principal crop irrigation well. Another example would be if the Census of Agriculture data helped to identify counties where specialty crops (such as sod, fruit, and mint) are primarily grown instead of principal crops (such as corn, potatoes, and beans). The irrigation water-use default rate was adjusted for those records that were reclassified.

2. Adjust well status or the active time intervals. - Some information on well owners with several approved highcapacity wells were sought to determine whether the farm was still active. A key database that aided in this task was the Farm Subsidy Database, available at $h t t p: / / f a r m$. ewg.org/farm/index.php (Environmental Working Group, 2006). Aerial photos and imagery also aided in determining whether an irrigation high-capacity well reported to be in the vicinity actually existed. On occasion, the 20-year active status default was extended to 40 years for some early constructed wells in order for the data to be more aligned with the irrigated acreage peak shown in Census of Agriculture reports.

3. Add past irrigation water use.-Because well records were more likely unavailable in earlier time intervals, 86 generalized reference locations were added to account for past irrigation that the well-based method missed. About half of these locations (44 records) were within the nearfield model area. The locations were based on where well construction reports indicate which well owners had or presently (2001-5) have the most irrigation wells. The generalized locations avoided areas where there were water bodies or areas that were highly urbanized.

\section{Assumptions and Limitations of Wisconsin Irrigation Data}

The groundwater withdrawals compiled and estimated for this study include the assumption that estimates provided in each data source are reasonably accurate and that the general location of withdrawals and water source did not change. A well-based approach, like that which was applied for Wisconsin, has greater certainty if most irrigators are accounted for, the majority of the well records have associated withdrawals, and the crop water requirement reflects typical crops grown, climate, and soil type irrigated. Other farm changes such as ownership, operation, crops, field rotation, or well status were not considered. Some data for early irrigation wells (mostly from the USGS GWSI) represented the entire county irrigation estimate derived from the Census-based method, whereas others distributed the estimate among a few active wells. Therefore, the water-use estimate for these irrigation records should not be used in a local-scale study without further consideration.

Several other assumptions and caveats should be kept in mind when using these data:

- If a well could not be determined for specialty agriculture or for other irrigation, then it was assigned as principal crop irrigation well.

- Golf course irrigation defaults may be unsuitable for certain areas of the Wisconsin LMB model area where water requirements diverge substantially from the average because of local variations in climate, turf species, soil moisture, and soil infiltration rates.

- Irrigation wells were assumed to be active only for 20 years; therefore, wells constructed before 1976 were assumed to be inactive unless a high-capacity well approval form indicated otherwise.

- Aquifer information for several records from the WDNR high-capacity well database contained erroneous aquifer codes. Use of information from nearby wells with a similar water-use purpose, casing depth, and well depth helped to determine aquifer and modellayer assignment.

- If well-depth information was missing for an irrigation well, the value was substituted by one of the following methods (in order of preference): the average depth of other irrigation wells owned by the same well owner within the county, the average depth of all other wells with a similar water-use purpose within the county (if not, then within the Wisconsin model area), or lastly, the average depth of all irrigation wells in the Wisconsin model area with reported depth information.

Farm-based data such as crop type were not available because of a confidentiality clause of the USDA Farm Service Agency (Larry Cutforth, U.S. Department of Agriculture, Farm Service Agency, written commun., 2006). If these had been available, a Geographic Information System (GIS) would have been used to intersect a well location with crop type, soil 
Estimation of Groundwater Use, Lake Michigan Basin and Adjacent Areas, 1864-2005

type, topography, and climate data to derive a site-specific water application rate. However, these factors might have been indirectly incorporated. Because more significant irrigation occurred after 1970, which was at about the same time when several water-use estimates were reported to the WDNR, it was assumed that these estimates likely reflect some site- and climate-related influences on the overall withdrawal.

A recent study comparing irrigation water use between two Wisconsin counties (Sauk and Waukesha Counties) found in the last time interval (2001-5) that the average water application rate for crop irrigation was 1,008 (gal/d)/acre (Gotkowitz and others, 2008). Therefore, water-use estimates based on approximated 1974 or 1979 water-application rates may have underestimated actual groundwater usage. However, the $1,008(\mathrm{gal} / \mathrm{d}) /$ acre is believed likely to be too high for particular counties in the model area, because it may better describe counties with more sandy soil and where more water-intensive crops such as potatoes are grown.

\section{Miscellaneous Water Use in Wisconsin}

Additional groundwater-use estimates not included within the previous water-use categories are assigned under the miscellaneous water-use category. In Wisconsin, this includes water uses identified for aquaculture ( 77 wells) and thermoelectric power generation ( 26 wells). The principal data sources were similar to those for the industrial wateruse category in that data from USGS, WDNR, and WGNHS were used. Miscellaneous withdrawals were represented in the smallest water-use category. The total estimated withdrawals for these uses range from $0 \mathrm{Mgal} / \mathrm{d}$ for the first three time intervals (1864-1940) to $19.09 \mathrm{Mgal} / \mathrm{d}$ for last interval (2001-5) (table 4). Approximately 90 percent of the miscellaneous water-use total for each time interval is attributed to aquacultural water use. Estimated withdrawals were notably lower before 1970 because of a lack of data.

On the basis of locations where these identified uses occurred, most early miscellaneous withdrawals were in the Southeastern Wisconsin and farfield model subregions; it was not until after interval 6 (1961-70) that groundwater development in Northeastern Wisconsin surpassed that of the other two model subregions (fig. $9 A$, appendix 2). The majority of miscellaneous use comes from the Cambrian-Ordovician aquifer system, followed by the Quaternary and Silurian-Devonian aquifer systems (fig. 9B, appendix 2). The distribution of miscellaneous withdrawals is fairly even by aquifer type, although there was slightly more use from deep confined bedrock (fig. $9 C$, appendix 2).

\section{Additional Wisconsin Miscellaneous Data Sources}

Additional sources were used to determine the location and amount of groundwater withdrawals for thermoelectric powerplant facilities. Water-use data at thermoelectric powerplants were available in documents furnished to the USGS by the WDNR and PSC for the 1985 and 1990 "Water Use in Wisconsin" compilations (Ellefson and others, 1987, 1993). More recently, the PSC supplied some additional powerplant groundwater-use and energy-production data for 2005 or 2006 (Scott Cullen and James Lepinski, Public Service Commission of Wisconsin, written commun. and unpub. data, 2006). Additional energy-production data and information came from the Energy Information Administration of the U.S. Department of Energy electricity databases (U.S. Department of EnergyEnergy Information Administration, 2006).

\section{Estimation Methods for Wisconsin Aquaculture Withdrawals}

Water-use estimates for aquaculture were based largely on data compiled by the USGS for the 2000 and 2005 "Water Use in Wisconsin" compilations (Ellefson and others, 2002; Buchwald, 2009). These data were based on several inquiries to aquacultural facilities and described their facility, production, and present water uses. Some facilities also described on their Web sites the source and amount of water used. Withdrawal history was less certain; therefore, the oldest well that could be identified for the facility was used to establish when groundwater use began. Withdrawal estimates for intervals 8 through 10 (1976 to 1990) were calculated by averaging the available reported data from the WDNR high-capacitywell database Web site (Wisconsin Department of Natural Resources, 2005). The average water-use rate was applied backwards to when the well was constructed. For a highcapacity aquacultural well with no withdrawal data available, the groundwater default of $9.64 \mathrm{Mgal} / \mathrm{yr}(0.0264 \mathrm{Mgal} / \mathrm{d})$ was applied. This default was determined in the 2005 "Water Use in Wisconsin" study by analyzing data from the State of Minnesota's water-use reporting program (Minnesota Department of Natural Resources, 2007; Buchwald, 2009).

\section{Estimation Methods for Wisconsin Thermoelectric Power Withdrawals}

Although surface water is the primary source of water for energy production and cooling, some powerplants supplement with groundwater for other energy-production needs such as plant service water (for different heat exchanges or plant systems), fly-ash control, or emergency cooling supplies. A list of Wisconsin's thermoelectric powerplants where the prime mover is steam turbine or combined cycle and steam was compiled along with the year the plants were established. There were no steam-based movers for thermoelectric power generation before the 1930s (Public Service Commission of Wisconsin, 1985). Some industrial facilities also generate electricity by way of steam, but no industrial facilities were identified with water wells exclusively for this purpose. Withdrawal estimates were calculated by averaging the available reported data for each well and applying the average backwards in time to when the well was constructed. The average withdrawal value for wells at thermoelectric powerplants during intervals 8 through 10 (1976-90) is $22.19 \mathrm{Mgal} / \mathrm{yr}$ (approximately 0.06 $\mathrm{Mgal} / \mathrm{d}$ ). This value was assigned as the default groundwater withdrawal rate if past withdrawal data for a well were not known. 


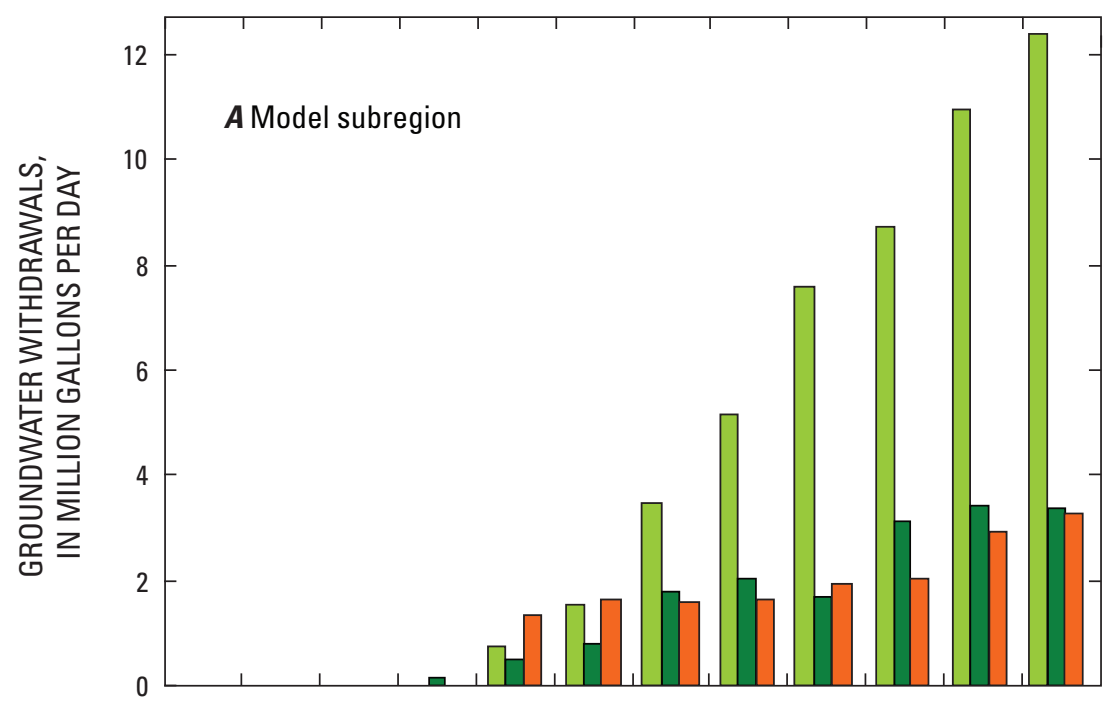

$\square$ Northeastern Wisconsin

$\square$ Southeastern Wisconsin

$\square$ Wisconsin farfield model area

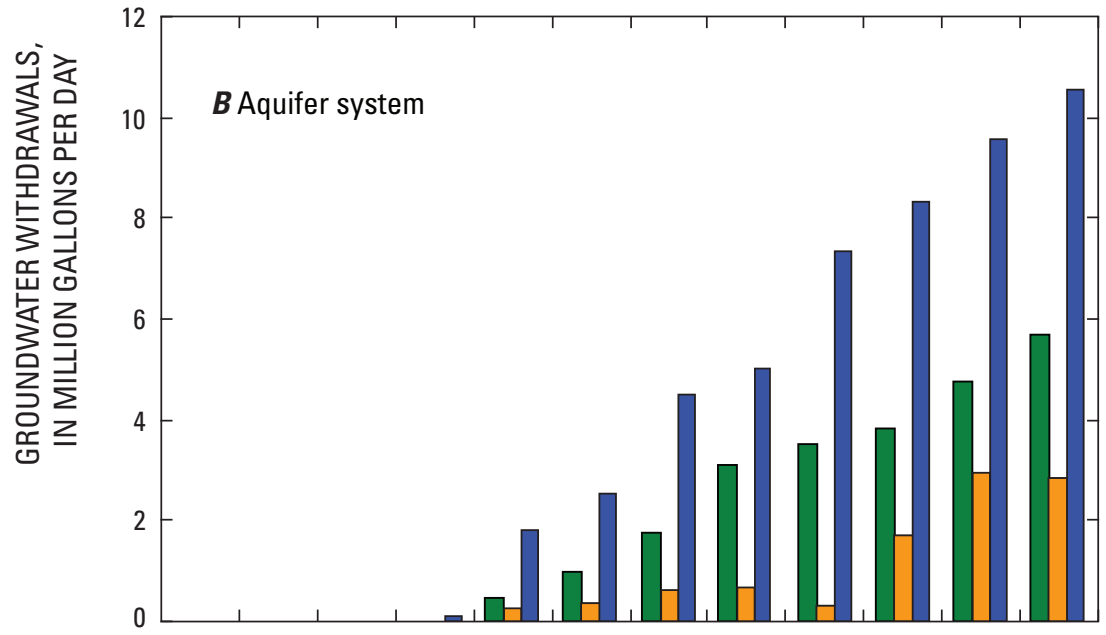

$\square$ Quaternary

$\square$ Silurian-Devonian

$\square$ Cambrian-Ordovician

焉

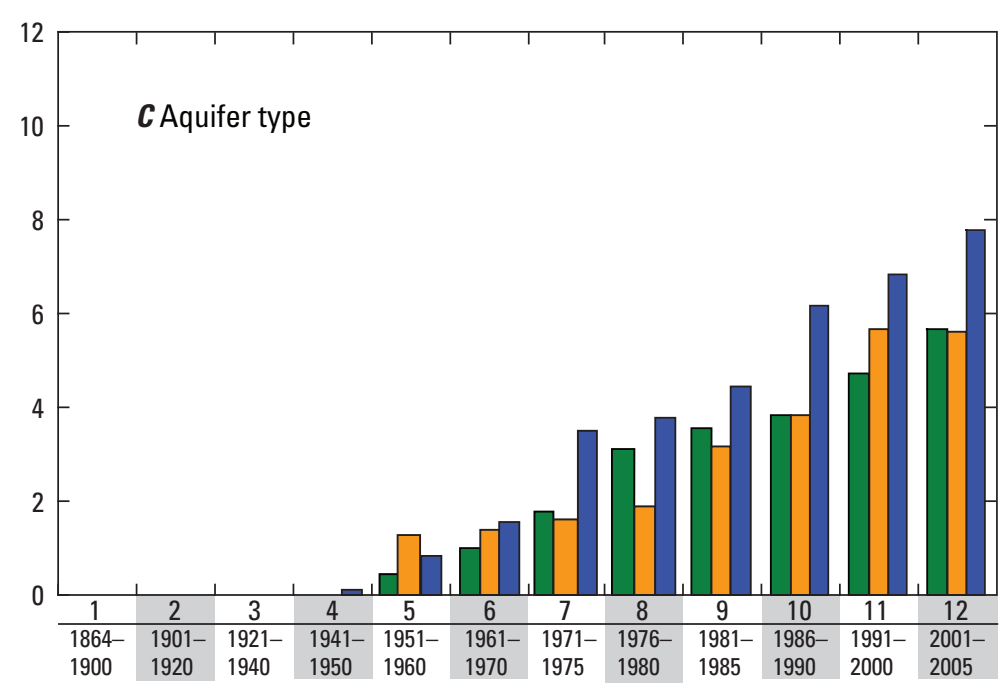

๑ Shallow unconsolidated material

$\square$ Shallow bedrock

$\square$ Deep bedrock

TIME INTERVAL AND YEARS

Figure 9. Miscellaneous groundwater-use estimates in Wisconsin for the Lake Michigan Basin model by time interval and $A$, model subregion, $B$, aquifer system, and $C$, aquifer type. Miscellaneous water use in Wisconsin includes groundwater withdrawals for aquaculture and thermoelectric power generation. The Jurassic-Mississippian aquifer system does not exist in Wisconsin. 


\section{Assumptions and Limitations for Wisconsin Miscellaneous Data}

Only facilities meeting the well-selection criteria described in the "Industrial Water Use" section are included. The groundwater withdrawals compiled and estimated for this study include the assumption that estimates provided by each facility are reasonably accurate. Estimates prepared for this study exclude some water use by miscellaneous users that could not be identified. Therefore, these water-use estimates likely underestimate actual groundwater usage. The high-capacity approval date was used for instances when the well-construction date was not known. A single groundwater requirement at powerplants or fish hatcheries was applied for each record in earlier and later time intervals by using the average withdrawal for time intervals 8 through 10 (1976-90), even if energy or aquacultural production demands and efficiency standards had changed. All wells identified for miscellaneous water use were assumed to be active through the last time interval unless indicated otherwise in the original data source.

\section{Michigan}

\section{History of Groundwater Management and Water- Use Data Collection in Michigan}

The Michigan Department of Environmental Quality (MDEQ) Water Use Reporting Program has been compiling information on water withdrawals for the major water uses in the State since 1997. The overall goal of the program is to establish an environmental baseline and continuing assessment of the major water uses - also referred to as "sectors" in Michigan - including power generation, industrial, irrigation, and public-supply water uses. These water-use data are collected to fulfill requirements of the Great Lakes Charter, a regional agreement signed by the Great Lakes States and Canadian Provinces in 1985, and Michigan's water-use reporting law (Part 327, Great Lakes Preservation, Natural Resources and Environmental Protection Act, 1994 Public Act 451, as amended) (Michigan Department of Environmental Quality, 2005a). Registration and reporting requirements are based on pump capacity, not actual water withdrawals.

The water-use-reporting protocols established under Michigan law vary from sector to sector. Before 1997, only public-supply water-use data were collected as required under the authority of Part 15 of the Administrative Rules for the Michigan Safe Drinking Water Act (1976 Public Act 399, as amended) (Michigan Department of Environmental Quality, 2006a). Water-use data for other categories, including irrigation and thermoelectric power generation, were collected periodically through intermittent surveys. Since 1997, thermoelectric powerplants, self-supplied industrial facilities, and irrigated golf courses that have the capacity to withdraw water greater than the Great Lakes Charter reporting threshold
$(100,000 \mathrm{gal} / \mathrm{d}$ averaged over a 30 -day period) have been required to report annual withdrawals to the MDEQ. All community public water-supply systems report monthly and/or annual water withdrawals. In addition, reported water use may be actual amount withdrawn or may be estimated by using pump capacities or some other means. Water-use amounts may be aggregated by the MDEQ by county or township. Metering of the water-withdrawal amounts is more frequently done by community public water-supply systems and thermoelectric powerplants than by industrial facilities and non-agricultural irrigators (Michigan Department of Environmental Quality, 2005b).

The MDEQ has estimated agricultural irrigation withdrawals from 1997 through 2006 by using a computer model that utilizes weather, soils, and other resource data, including crop and acreage information reported in the Census of Agriculture (Michigan Department of Environmental Quality, 2006a). This irrigation-demand model (Jeffrey A. Andresen (and others), Michigan State University, written commun., 2000) is based on a 1997 Federal agricultural census as a baseline for 1997-2001 water-use estimates and a 2002 federal agricultural census as the baseline for 2002-6 estimates (Michigan Department of Environmental Quality, 2006b). Because non-agricultural irrigation water withdrawals typically occur from May through September, comparisons with other facility types that have more consistent year-round pumping may be difficult because the posted values are all annualized averages. Comparison of the reported agricultural water withdrawals with the 2002 National Agricultural Statistics Service (NASS) irrigation survey indicates that Michigan Department of Agriculture (MDA) reports cover about 70 percent of the irrigated acres tabulated by NASS, with over 90 percent of non-agricultural, primarily golf course, groundwater users reporting.

\section{Overview of Michigan Data From the Lake Michigan Basin Study}

For this report, the Michigan LMB model area consists of those counties in Michigan with at least some part within the boundaries of the basin, plus Monroe County (fig. 10). Monroe County water use was included in the public-supply and industrial category estimates along with the Lake Michigan Basin counties because of large groundwater withdrawals for industrial use (Michigan Department of Environmental Quality, 2004). From Michigan's total of 83 counties, water-use estimates were determined for public-supply use in 56 counties, for industrial use in 47 counties, for agricultural irrigation use in 11 counties, and for golf course irrigation use in 49 counties (fig. 11). Overall, there were 2,046 withdrawal locations estimated for counties within the Michigan LMB model area, and 1,860 locations were active in the last time interval (2001-5) for a total withdrawal of $397.72 \mathrm{Mgal} / \mathrm{d}$ (table 2). 


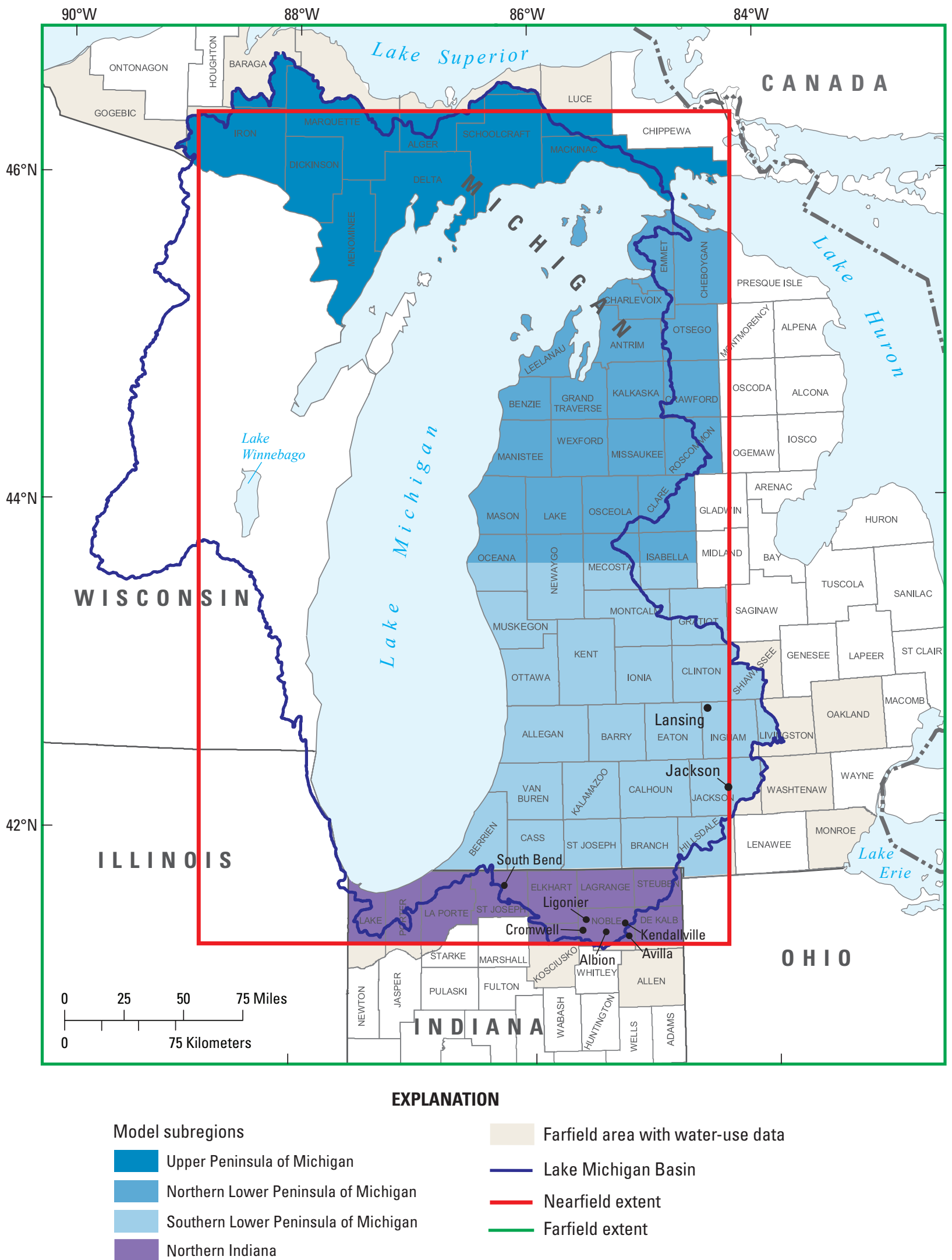

Figure 10. Michigan and Indiana model areas of the Lake Michigan Basin model. (Water-use data vary by category in this model area. Refer to figure 11 to identify farfield counties in Michigan with water-use data for each category.) 

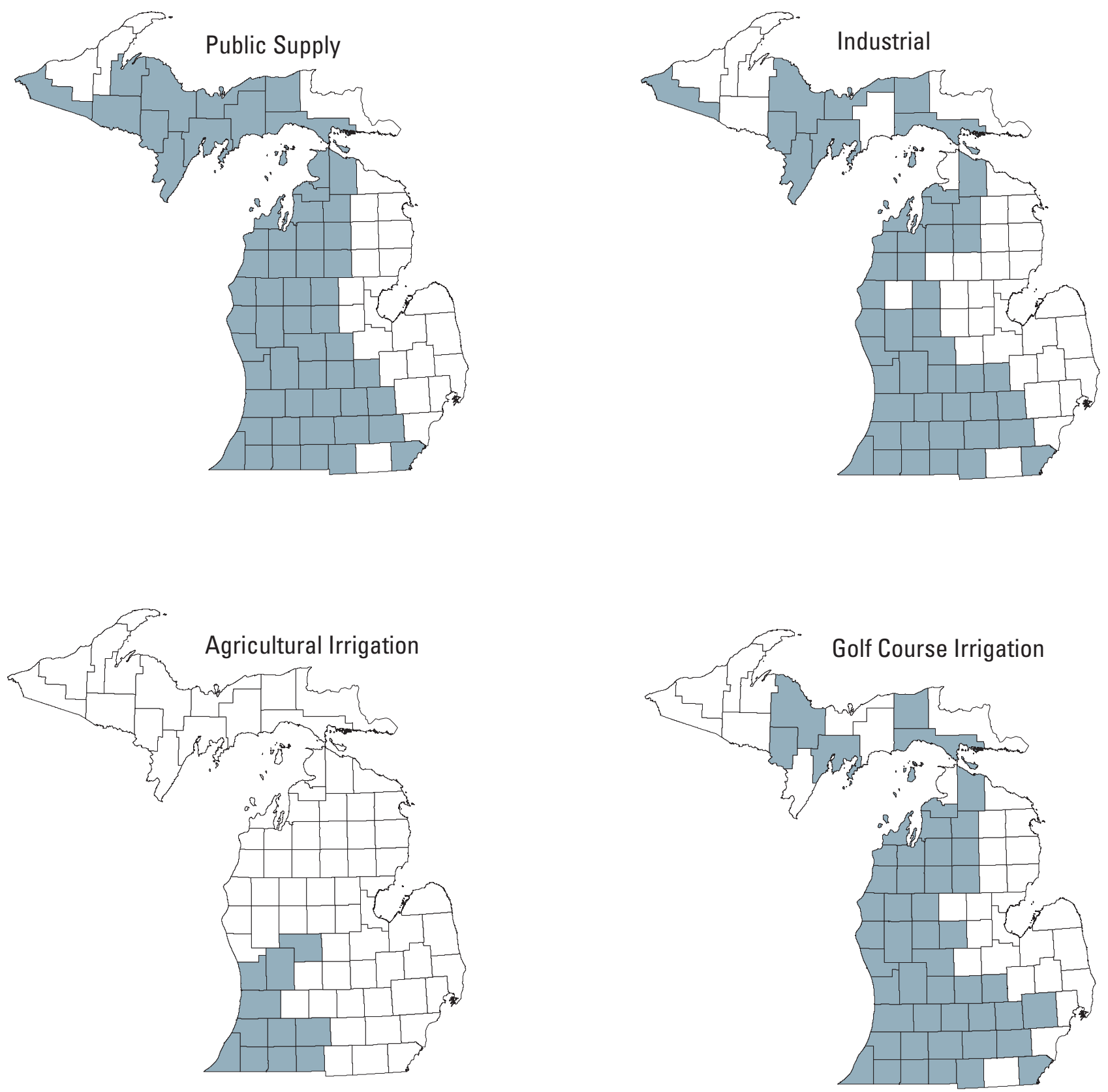

Figure 11. Michigan counties for which groundwater-use estimates were made for the Lake Michigan Basin model, by category. (Shaded counties have water-use estimates.) 
Information on water resources in Michigan is available from many sources, ranging from individual county investigations to statewide summaries. In August 2003, Public Act 148 was passed by the Michigan Legislature to address groundwater conflicts, to inventory and map Michigan's groundwater resources, and to create the Groundwater Conservation Advisory Council. As part of the inventory of Michigan's groundwater resources, the location and water-yielding capacity of the aquifers in the State were determined. Aquifers in the unconsolidated materials tend to be complex and are generally extremely heterogeneous. Groundwater is readily available from bedrock in the central and southern parts of the Lower Peninsula. Lower estimated yields are typical from sandstone and carbonate bedrock aquifers in the Upper Peninsula and from predominantly carbonate strata in the northern swath of the Lower Peninsula and in the southeast corner of the State. Some areas of the Lower Peninsula are characterized by shale bedrock units that normally do not serve as aquifers, and much of the western Upper Peninsula is characterized by hard-rock units that produce groundwater only along localized fracture traces. The aquifer systems available throughout the Michigan LMB model area are the Quaternary, Jurassic-Mississippian, Silurian-Devonian, and the Cambrian-Ordovician. In general, groundwater development in the Michigan LMB model area has occurred in areas of greater groundwater availability, which have been where Quaternary deposits of glacial material are thick or where bedrock units subcrop beneath the glacial deposits. Aquifer-distribution and thickness maps can be found in the stratigraphy report for the LMB model (Lampe, 2009).

Well logs collected for this study show that most early development was in the central part of the Lower Peninsula of Michigan, which corresponds to the northern part of the Southern Lower Peninsula subregion and the southern part of the Northern Lower Peninsula subregion used in this report. Estimated withdrawals for the nearfield model area equal 7.43 $\mathrm{Mgal} / \mathrm{d}$ in time interval 1 (1864-1900) and $359.91 \mathrm{Mgal} / \mathrm{d}$ in interval 12 (2001-5); farfield model area withdrawals equal $0.63 \mathrm{Mgal} / \mathrm{d}$ in interval 1 and $37.81 \mathrm{Mgal} / \mathrm{d}$ in interval 12 (table 2 ). When evaluating these estimated withdrawals for Michigan, it is important to remember that water-use estimates were compiled primarily for counties within the nearfield model area and that these estimates do not represent the total amount of groundwater withdrawn in Michigan for these categories. Farfield estimates compiled for this study are from Monroe County and other counties intersected by the nearfield model boundary. Estimated withdrawals by nearfield model subregions for interval 1 (1864-1900) to interval $12(2001-5)$ range from $7.21 \mathrm{Mgal} / \mathrm{d}$ to $306.15 \mathrm{Mgal} / \mathrm{d}$ in the Southern Lower Peninsula, $0.22 \mathrm{Mgal} / \mathrm{d}$ to $44.83 \mathrm{Mgal} / \mathrm{d}$ in the Northern Lower Peninsula, and 0 to $8.94 \mathrm{Mgal} / \mathrm{d}$ in the Upper Peninsula (table 3).

Additional analysis was done for farfield counties not mentioned above. These farfield counties are located primarily along the eastern side of the Lower Peninsula of Michigan and to the north in the Upper Peninsula. No withdrawals in Houghton and Keweenaw Counties were included in model datasets because wells were outside of the model boundaries. This analysis of farfield model area withdrawals was done to quantify withdrawals omitted from model simulations, even though such omissions would most likely have little effect on model results; most withdrawals are from the unconsolidated material and shallow unconfined bedrock aquifers, so drawdowns in these areas are expected to have little influence on the exchange of water between the model farfield and nearfield areas (Daniel Feinstein, U.S. Geological Survey Wisconsin Water Science Center, oral commun., 2008). In interval 12 (2001-5), groundwater withdrawals of $397.72 \mathrm{Mgal} / \mathrm{d}$ were reported for counties in the Michigan study area, with $285.36 \mathrm{Mgal} / \mathrm{d}$ from unconsolidated materials and $112.36 \mathrm{Mgal} / \mathrm{d}$ from bedrock aquifers. Groundwater withdrawals of $51.23 \mathrm{Mgal} / \mathrm{d}$ were reported for public-supply, industrial, and golf course uses in 2004 for the counties not included in the Lake Michigan Basin analysis, with $40.62 \mathrm{Mgal} / \mathrm{d}$ from unconsolidated materials, $9.03 \mathrm{Mgal} / \mathrm{d}$ from bedrock aquifers, and $1.59 \mathrm{Mgal} / \mathrm{d}$ from unknown sources. Groundwater withdrawals of $35.92 \mathrm{Mgal} / \mathrm{d}$ were reported for agricultural irrigation uses in 2004 for the counties not included in the Lake Michigan Basin analysis; however, the aquifer units for these withdrawals were not determined.

\section{Principal Michigan Data Sources}

The MDEQ Water Use Reporting Program maintains a Web site where groundwater and surface-water withdrawal data by county and USGS hydrologic basin are available for 1997 to 2005 for the public-supply category and for 1997 to 2004 for the industrial and irrigation categories (Michigan Department of Environmental Quality, 2005a). As part of the groundwater inventory and mapping (GWIM) project, the location and pump capacity of all public water-supply systems, all registered industrial facilities, and all registered non-agricultural irrigation facilities that have the capacity to withdraw more than $100,000 \mathrm{gal} / \mathrm{d}$ average in any consecutive 30-day period were compiled on the basis of 2003 data (Michigan Department of Environmental Quality, 2006c). The information on the GWIM Web site includes groundwater use by system with facility location, 2003 groundwater withdrawals, source information, and pump-capacity information with selected well-construction details. In addition, the GWIM Web site contains water use reported to the Michigan Department of Agriculture (MDA) for agricultural producers in the State that met water-pump capacity thresholds ( $70 \mathrm{gal} / \mathrm{min}$ ) during the 2004 calendar year. This agricultural water use was required to be aggregated by township by Public Act 148. As described in subsequent sections, the information on the GWIM Web site was used primarily as a source of supplemental withdrawal data that permitted the distribution of county-level data proportionally to point locations, as a source of supplemental well-construction information, and as a means to determine locations for water withdrawals for the industrial and irrigation categories. The MDEQ also maintains an extensive electronic database of water-well records, Wellogic, which was used for additional well-construction information including construction date, depth, and lithologic description. 
Additional water-use data were compiled from previous investigations and data-compilation efforts or were estimated for this study. If there were water-use data representing multiple years within a model time interval, then the average of these data was assigned to the midpoint of the model time interval. Groundwater withdrawals were determined for the available years of data for those time intervals when the well was assumed to be in operation for 3 or more years of the interval, and that average was used to represent the entire interval; otherwise, no withdrawals were specified. Because of the generally sparse historical data available and the uncertainty in knowing the actual date withdrawals were initiated (because well-construction information for many wells was missing or incomplete), this method helps ensure that withdrawal estimates are reasonable for each time interval. Using a zero value for years with unreported data would yield wateruse estimates that would not be representative for facilities where a well was suspected to have been in operation but was without reported withdrawals for some years. When sufficient detailed information was available, water use was estimated for each withdrawal location or well; however, in some cases, site-specific data were unavailable, and a composite estimate was assigned to the facility or to an approximate well-field center point.

Population data for communities with public water-supply systems within the selected counties were compiled from U.S. Bureau of the Census reports. In the selected counties, at least some population data was reported for 231 communities from 1880 to 2000 . The population data indicate an upward trend (fig.12); however, population figures from before 1930 were unreported for many communities, possibly because they had not been incorporated yet. For 1970 until 2000, all 231 communities except for 1 had reported data for each census year. In 1880, population was reported for 144 communities, compared to 231 in 2000. Available data for the selected counties in the Michigan Lake Michigan Basin area indicate growth in population from 1.8 million people in 1930 to about 4.3 million people in 2000, an increase of over 133 percent.

\section{Public-Supply Water Use in Michigan}

During the mid-1800s, water supply was primarily from surface-water sources; however, with increased urbanization during the late 1800 s, public water-supply systems withdrawing groundwater were developed to supplement private wells. The City of Jackson, Jackson County, is one of the oldest water-supply systems in the area and supplied potable groundwater in 1880. Within the Michigan Lake Michigan Basin area, 51 public water-supply systems were operating prior to 1900. Surface-water use peaked between 1920 and 1930; after 1930 , some public water-supply systems began using groundwater that was less susceptible to contamination. After 1960, surface-water use increased again in areas with inadequate groundwater supplies, mostly near large cities that already used surface water as their primary source of water (Baltusis and others, 1992). Groundwater-withdrawal data indicate an upward trend until the late 1960s, after which withdrawals leveled off as surface water became a more important source for some public water-supply systems (fig. 13).

For time interval 1 (1864-1900), groundwater-withdrawal data were reported or estimated for 31 utilities, or public water-supply systems, in the Michigan LMB model area. Most of the remaining 20 utilities withdrawing surface water during the first time interval later switched to groundwater, mostly from unconsolidated material sources. For the last time interval, groundwater-withdrawal data were available for 796 utilities in the Michigan LMB model area. For this category, initial withdrawals were estimated for combined timespans of 1971-80 and 1981-90 instead of separate 5-year time periods. Later, as these data were incorporated into the groundwaterflow model, withdrawals estimated for 1971-80 were assigned to intervals 7 and 8 (1971-75 and 1976-80), and withdrawals estimated for 1981-90 were assigned to intervals 9 and 10 (1981-85 and 1986-90). Each time interval combined both reported (from current and historic studies) and estimated data except interval 12 (2001-5), which relied on reported data.

Of the total amount of groundwater withdrawn in Michigan for public supply in 2004, about 81 percent was withdrawn by counties within the Michigan LMB model area. Estimated total groundwater withdrawals by public watersupply systems in the Michigan LMB model area equaled $8.06 \mathrm{Mgal} / \mathrm{d}$ for the first time interval (1864-1900) and 196.98 $\mathrm{Mgal} / \mathrm{d}$ for the last interval (2001-5) (table 4). Groundwater withdrawals from the Michigan LMB model area are and have historically been primarily from the Southern Lower Peninsula; withdrawals since 1971 have remained relatively constant from each of the model subregions (fig. 14A, appendix $3 A$ ). Most public water-supply systems within the Michigan LMB model area withdrew water from a single aquifer system; however, some systems that relied on the Quaternary aquifer system later added, or switched to, wells that withdraw water from one of the bedrock aquifer systems. Publicsupply groundwater withdrawals have been primarily from the Quaternary and the Jurassic-Mississippian aquifer systems, whereas few withdrawals have been from the deeper aquifer systems (fig. 14B, appendix 3B). Groundwater withdrawals from the Quaternary aquifer system show a slight upward trend since 1971 (interval 7). Public-supply groundwater withdrawals have also been primarily from unconfined unconsolidated material, followed by shallow unconfined bedrock and deep confined bedrock (fig. 14C, appendix 3C). Groundwater withdrawals from the deep confined bedrock have remained relatively constant since 1971, whereas groundwater withdrawals from the unconfined unconsolidated materials have increased slightly and withdrawals from the deep confined bedrock have decreased slightly since 1971 . 


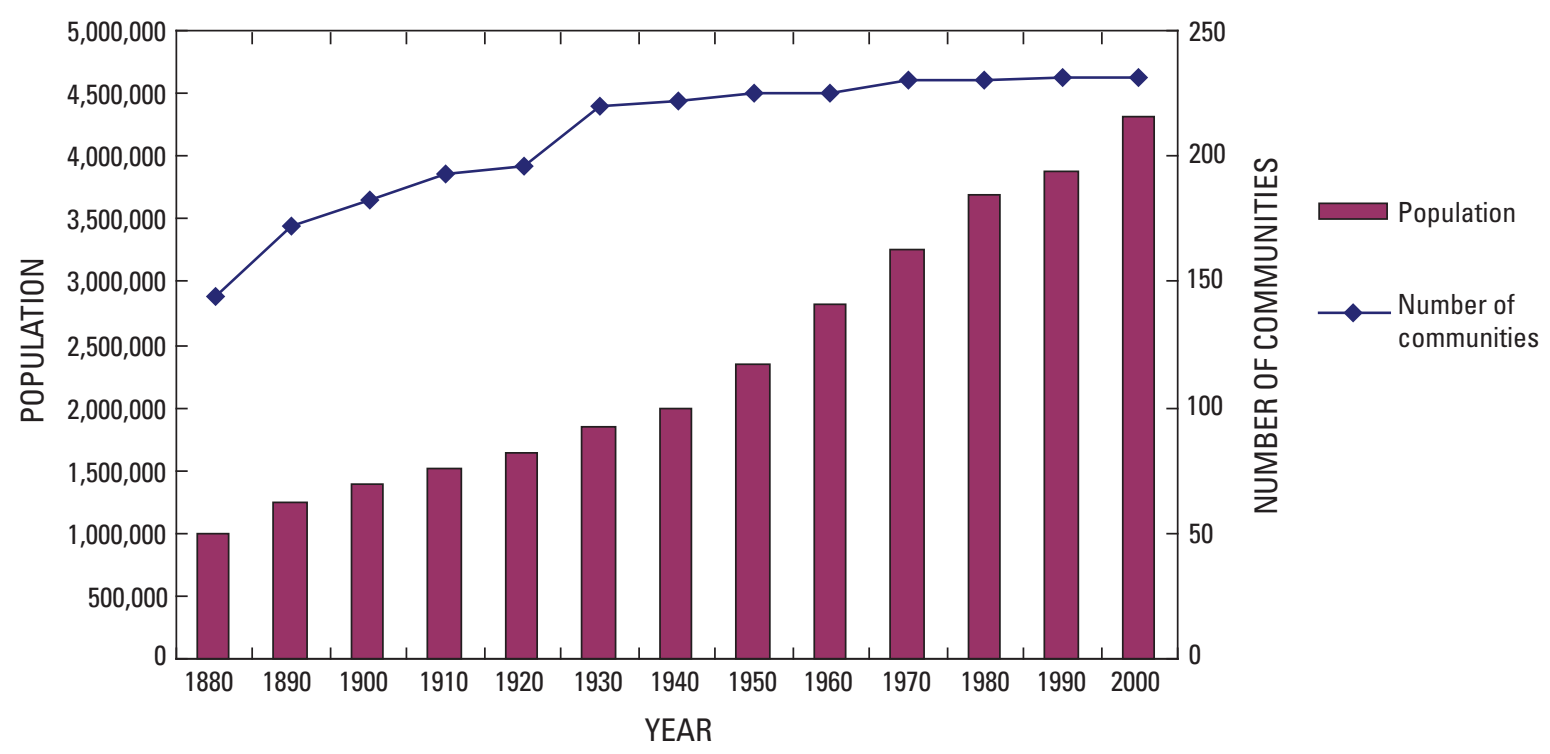

Figure 12. Population and number of communities in Michigan counties in the Lake Michigan Basin area.

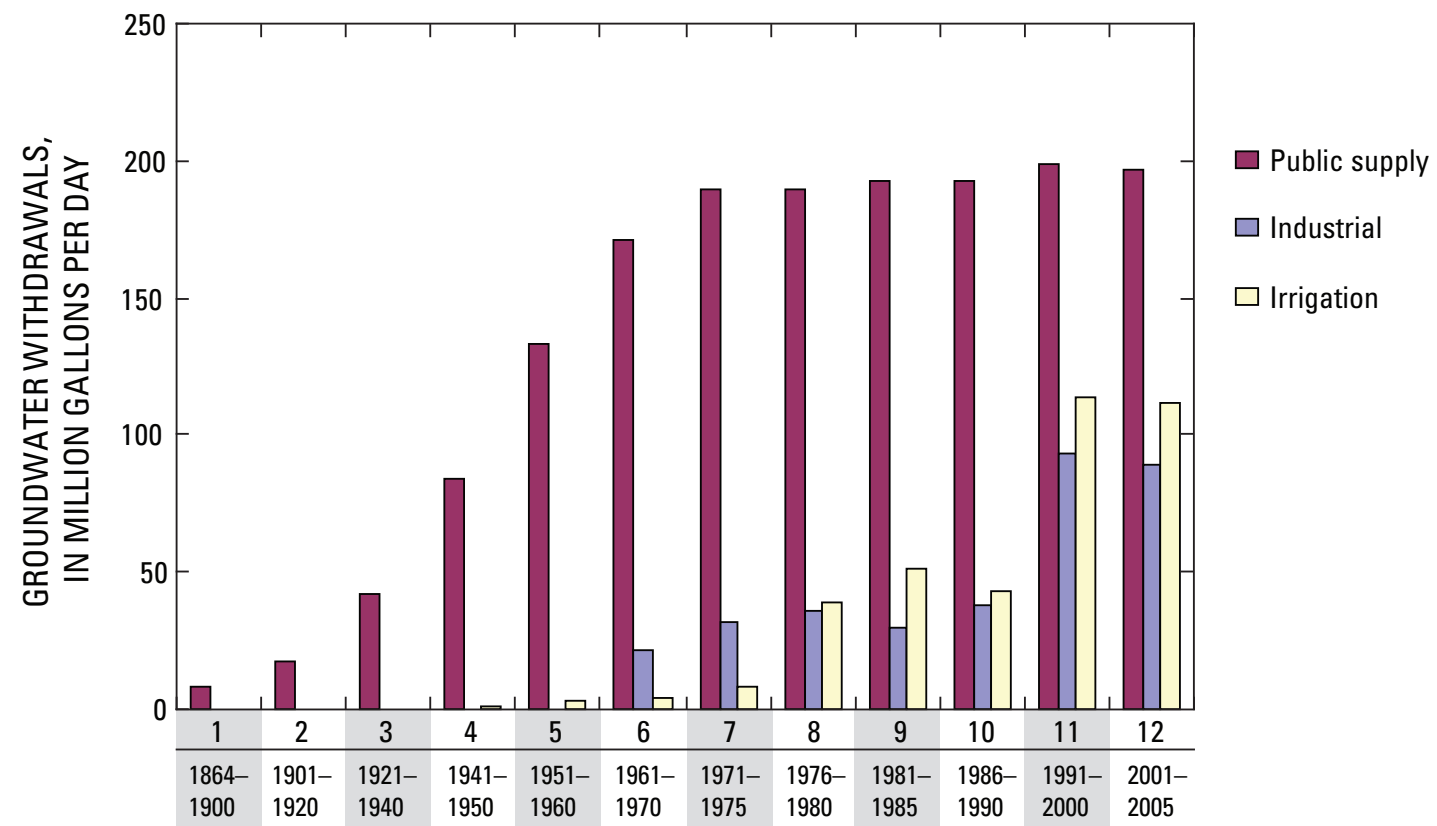

TIME INTERVAL AND YEARS

Figure 13. Michigan groundwater-use estimates for the Lake Michigan Basin model by time interval and category. No estimates were determined for industrial use for time intervals 1 to 5 and for irrigation use for time intervals 1 to 2 . Irrigation estimates for time intervals 6 to 10 include agricultural use only; estimates for time intervals 11 and 12 include agricultural and golf course uses. Industrial and irrigation groundwater use prior to time interval 11 is estimated and likely does not represent historical trends. Values reflect only a partial estimate of water use in Michigan. 


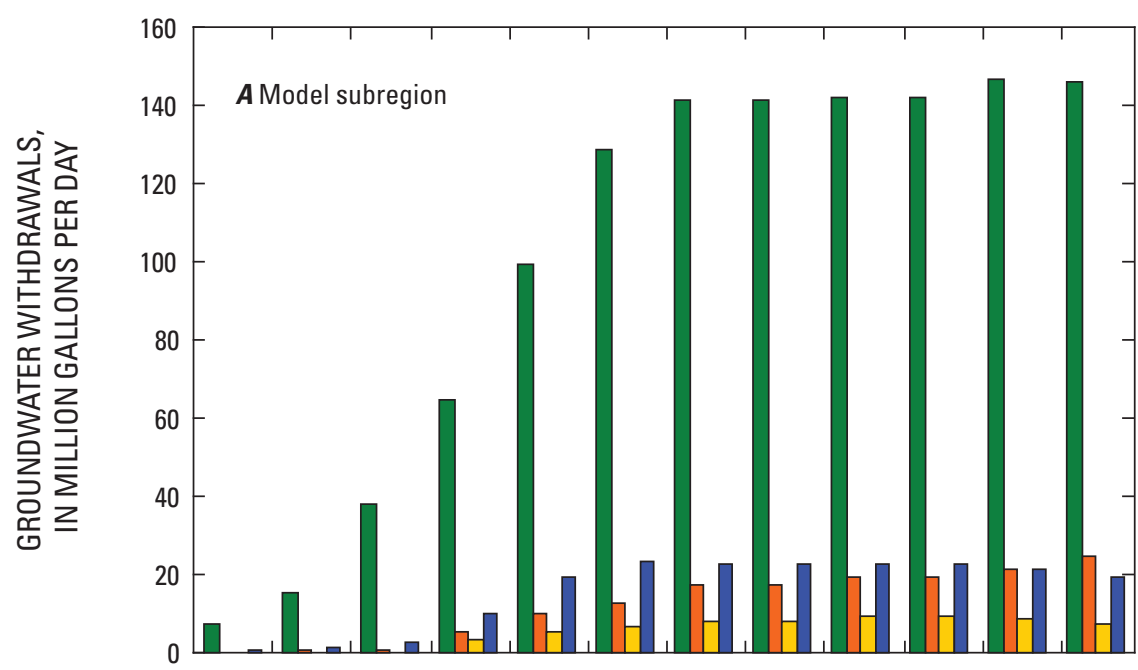

$\square$ Southern Lower Peninsula

$\square$ Northern Lower Peninsula

$\square$ Upper Peninsula

$\square$ Michigan farfield model area

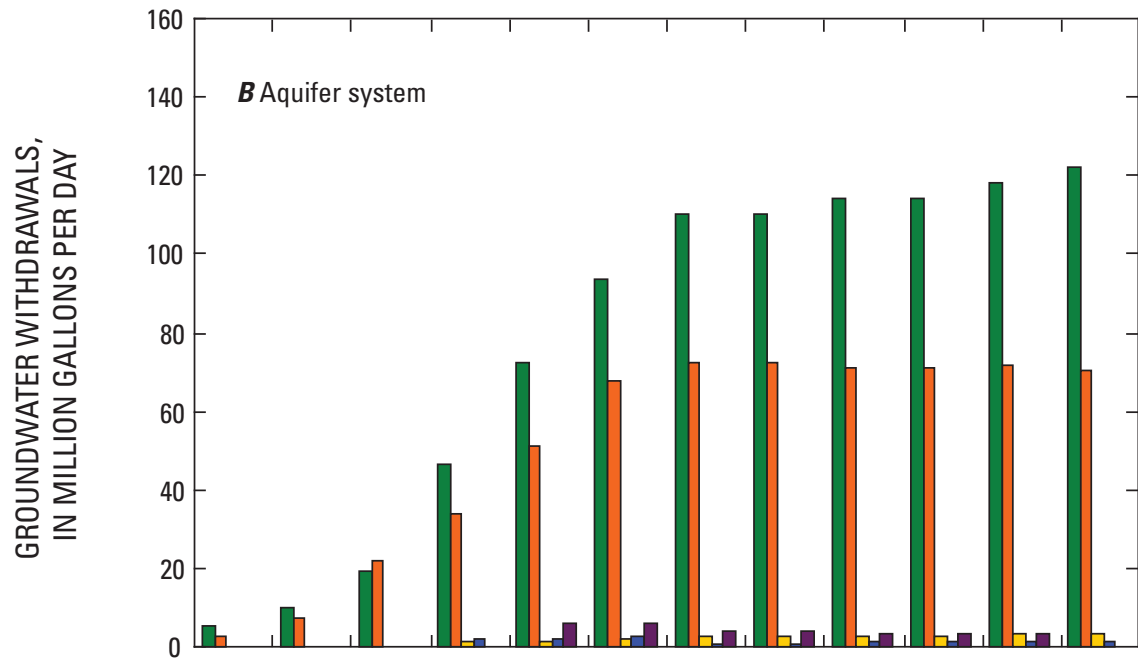

$\square$ Quaternary

$\square$ Jurassic-Mississippian

$\square$ Silurian-Devonian

- Cambrian-Ordovician

- Mixed

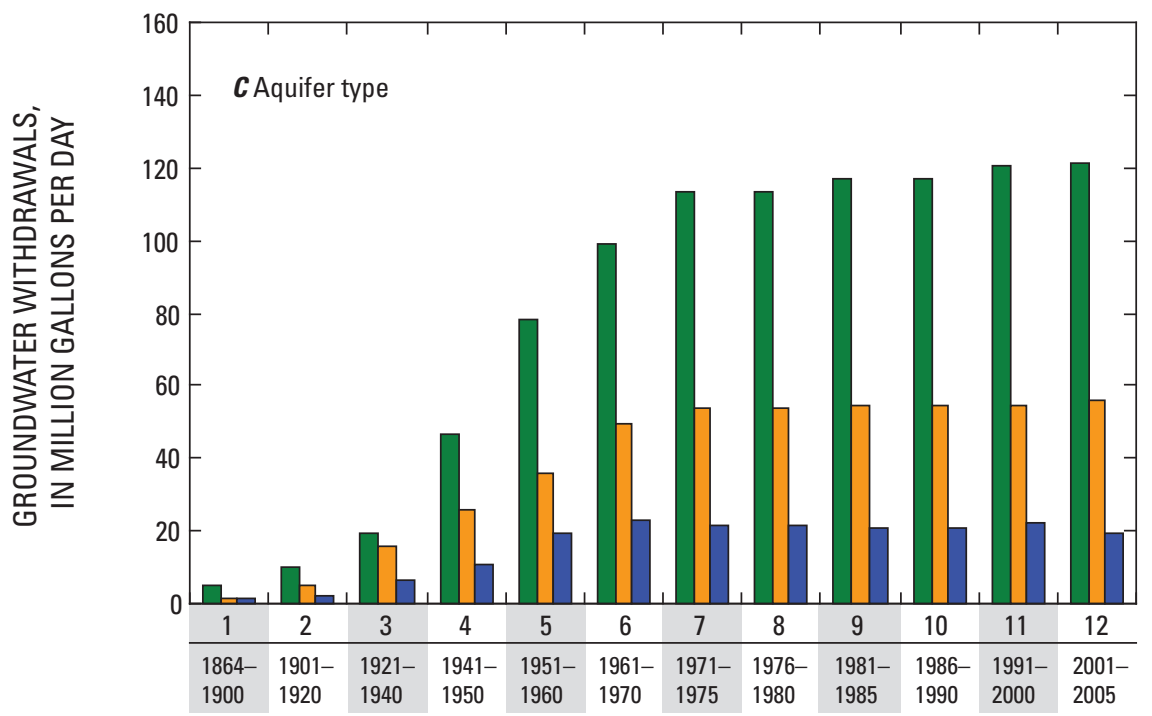

— Shallow unconsolidated material

$\square$ Shallow bedrock

$\square$ Deep bedrock

TIME INTERVAL AND YEARS

Figure 14. Public-supply groundwater-use estimates in Michigan for the Lake Michigan Basin model by time interval and $A$, model subregion, $B$, aquifer system, and $C$, aquifer type. Values reflect only a partial estimate of water use in Michigan. 


\section{Additional Michigan Public-Supply Data Sources}

Water withdrawals for public supply were estimated by using data from previous reports, former USGS modeling water-use datasets, the MDEQ Water Use Reporting Program and GWIM Web sites, written communications, and estimated per capita use. Some historical groundwater-withdrawal data from 1970 to 1990 have been supplied by public water-supply systems for annual groundwater-data reports prepared by the USGS (Huffman and Thompson, 1971, 1973; Huffman, 1974a, 1974b, 1975, 1976, 1977, 1979a, 1979b, 1980, 1981, 1982, 1983, 1984, 1985, 1986, 1988; Huffman and Whited, $1988,1989,1991,1993)$. Additional data were available from previously published reports, including those by the Michigan Department of Public Health (1943), the Michigan Department of Health (1961), Bedell (1982), Baltusis and others (1992), Holtschlag and others (1996), Luukkonen and Westjohn (2001), and Luukkonen and others (2004). Some additional withdrawal information was available from written communications by Mark Breithart (Michigan Department of Environmental Quality, 1995) and Ron Van Til (Michigan Department of Environmental Quality, 1995, 2004) or was compiled from survey forms received from individual public water-supply systems in 1992.

Reported geologic information, along with the well depth, primarily came from the Wellogic database and was used with data from previous studies and reports to determine the hydrologic unit where withdrawals came from. For those utilities with missing or incomplete well-log data, an effort was made to locate data via the GWIM Web site; wells near the reported utility's withdrawal location were inspected to determine whether there was a match to any other wells with the same owner, operator name, or well address field. These data sources often included well-construction dates, which were helpful for determining when the well became active. Altogether, there were 852 public water-supply systems relying on groundwater with withdrawal estimates determined for 1,041 well, well-field, or utility locations.

\section{Estimation Methods for Michigan Public-Supply Withdrawals}

Water-use estimates for each public water-supply system for time intervals with available withdrawal data were calculated by averaging the reported data in each interval. These are considered estimates for each water-supply system because complete data for each year were not available for any of the intervals.

For time intervals with no reported withdrawal data, water-use estimates were based on estimated per capita use and population. Per capita use was calculated for the time intervals with reported data as follows:

- An average withdrawal per year for each community was calculated for each year of available data.
- An average population was determined for each timeinterval midpoint by using the population data as reported by the census for each decade.

- This average withdrawal was then divided by the average population to produce a per capita use rate.

The per capita use estimates tended to vary between the communities and among the time intervals (fig. 15) in response to short-term economic changes, changes associated with local population changes, and reported source changes (Baltusis and others, 1992). Over all time intervals and communities, estimated per capita use ranges from 0.7 to $1,305 \mathrm{gal} / \mathrm{d}$ per person and averages $148 \mathrm{gal} / \mathrm{d}$ per person. Small per capita use rates likely represent public water-supply systems that supply water almost exclusively for residential use; larger per capita use rates likely represent public water-supply systems that supply water for many uses, such as residential, commercial, industrial, and/or thermoelectric power generation. For each community, an average per capita use was computed to represent those time intervals with no available withdrawal data, using adjacent intervals for which estimated values were available. This per capita use rate was multiplied by the average population for each time-interval midpoint to determine the publicsupply water-use estimate. This rate was assigned to the community or well-field location for those water-supply systems with incomplete well data or was divided equally between all possible wells assigned to each community. In only a few cases does a water-supply system's well field extend over multiple model cells; therefore, assignment of water-use estimates to the water-supply system or well-field location produces the same net effect on model simulations, assuming withdrawals are from the same layer. In those cases where well data were incomplete but where withdrawals were determined to come from multiple cells or multiple layers within the same cell, water-use estimates were applied to the appropriate cells and layers so that model input data would represent system withdrawal depths. A withdrawal amount was estimated for each decade with a reported population count.

The initial start date for pumping in each community was determined by the well-construction date or from information in available reports. Water-use estimates were specified for each time interval beginning with the interval when the well was installed. Withdrawal amounts were estimated from the trend observed for the more recent intervals for which reported data were available. If no well data were available, as was the case for some schools and mobile home parks, withdrawals were estimated back to time interval 9 (1981-85). No water-use estimates were specified before interval 9 for these types of facilities because, in the absence of well-log data, no information was available to determine when withdrawals had begun. 


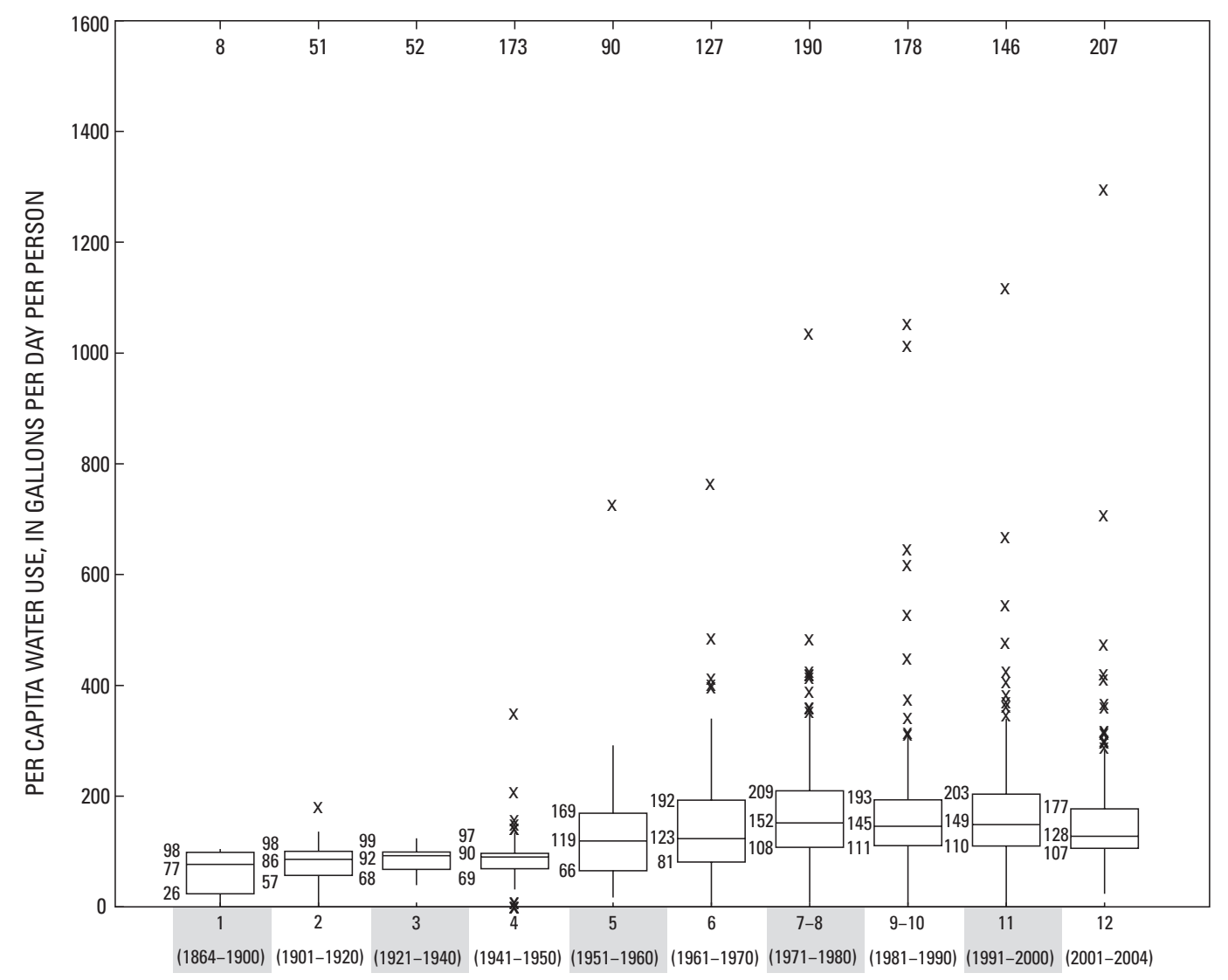

TIME INTERVAL AND YEARS

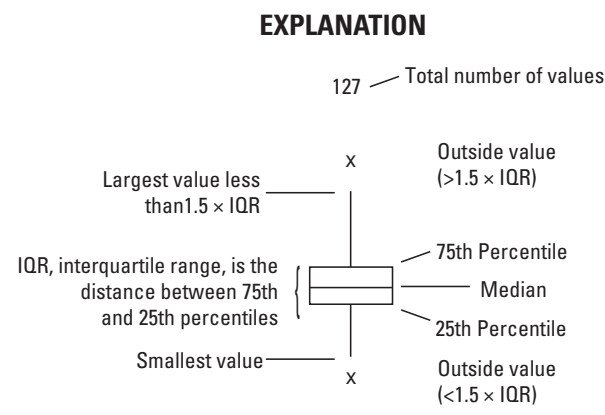

Figure 15. Public-supply per capita water use in the nearfield model area of Michigan, 1869-2004.

\section{Assumptions and Limitations of Michigan Public-Supply \\ Data}

The groundwater withdrawals compiled and estimated for this study include the assumption that estimates furnished by each utility are accurate, reliable, and consistent from year to year. Estimates for each year also are based on the assumption that the location of withdrawals and sources did not change over time unless reported otherwise. Estimates were determined for utilities listed as water-supply systems in 2003. Therefore, the estimates prepared for this study could be missing water use by communities that were not listed in 2003 and that withdrew water and then ceased operations or changed to surface water or a purchased source. Only those utilities that met the reporting-capacity threshold are included in the data reported for 1997-2005; therefore, these water-use estimates likely underestimate actual groundwater usage. For those water-supply systems without individual well data, estimates are based on the assumption that the utility location is near the actual well field and is thus representative of the withdrawal location and that any supplemental information available accurately identifies the aquifer from which water is withdrawn. Water-use estimates prepared for 1971-1980 and 1981-90 are assumed to be representative of withdrawals for the 5-year intervals in intervals 7 through 10. Impacts from withdrawals outside the Michigan LMB model area that were not included in this compilation are expected to be small and inconsequential to the water levels in the nearfield model area or primary area of interest in the basin. However, these withdrawals could affect inset-model results if any local models are placed in this area. 
The population estimates compiled from U.S. Bureau of the Census reports also are assumed to be accurate and collected in a consistent manner each census year. Water use estimated by means of population data includes the assumption that population data were accurately recorded and published by census at the same time the water-supply system began supplying customers and, likewise, that withdrawals were initiated when a well was installed. Water use estimated from per capita use includes the assumption that all people residing in the community were supplied by the public watersupply system and that no areas outside of the community were supplied by the same water system. Thus, these estimates could be missing water withdrawn by one water-supply system and sold to another and could be overestimating withdrawals if only part of the community is served by the water-supply system. Water-use estimates calculated from per capita values are based on the assumption that the proportion of residential versus other uses is the same for each time interval for each community. Therefore, these public-supply water-use estimates could be missing water distributed for publicly supplied industrial or other uses before 1985 or could be overestimating withdrawals in areas where industrial facilities ceased operation during the time interval.

\section{Industrial Water Use in Michigan}

At the national level, the Great Lakes Region withdraws the largest volume of water for self-supplied industrial purposes, with a relatively small number of facilities accounting for the majority of withdrawals (Michigan Department of Environmental Quality, 2004). Increasingly, however, process water is being recycled or recirculated, reducing water withdrawals in some manufacturing sectors. In 2004, about 62 percent of Michigan's industrial self-supplied groundwater withdrawals were for chemicals and allied products, mining and quarrying, and food and kindred products (Michigan Department of Environmental Quality, 2004).

Unfortunately, historical data on amounts of water withdrawn for industrial uses are sparse in Michigan. Census of Manufacturing data were available (for example, U.S. Department of Commerce-Bureau of the Census, 1982, 1992); however, the relationship between the number of manufacturing establishments and water use is unclear and likely has changed over time. The percentage of the total number of manufacturing establishments that are self-supplied and withdraw groundwater is unknown and also has likely changed over time. Therefore, withdrawals were not estimated for model time intervals prior to interval 6 (1961-70) because of the absence of data about groundwater-withdrawal amounts and locations and the years of operation of various industries (table 4). Available data from 1997 to 2004 indicate that most industrial facilities are publicly supplied (Michigan Department of Environmental Quality, 2006b) and that the majority of self-supplied industrial withdrawals are from surface water; therefore, it is possible that groundwater withdrawals prior to 1960 were small.

For this category, withdrawals were estimated for each time interval after 1960, intervals 6 through 12 . Groundwater use for interval 6 was estimated for 14 facilities with available well-log data in the area. For interval 12 (2001-5), groundwater-withdrawal data were available for 198 facilities in the Michigan LMB model area. Estimated total industrial withdrawals in the Michigan LMB model area equaled 21.47 $\mathrm{Mgal} / \mathrm{d}$ for interval 6 (1961-70) and $89.36 \mathrm{Mgal} / \mathrm{d}$ for interval 12 (2001-5) (table 4). Some water withdrawn for industrial use in the LMB model area is released to nearby wetland areas, lakes, or rivers to recharge the groundwater system after being used for noncontact cooling purposes (table 10). For the purposes of this report, however, total withdrawals listed in tables in this report do not reflect a subtraction of any amounts that might be used to recharge the groundwater system. No withdrawals were estimated for commercial use, owing to a lack of data on withdrawal amounts and uncertainty in whether the water was publicly supplied or self-supplied; however, some facilities classified as industrial in Michigan may be considered as a commercial type in other states.

About 98 percent of the groundwater withdrawn for self-supplied industrial uses in 2004 in Michigan was withdrawn by counties in the LMB model area. For the last two time intervals, groundwater withdrawals from the Michigan LMB model area were primarily from the Southern Lower Peninsula. Withdrawals from the Northern Lower Peninsula and the farfield model area were about equal, and withdrawals from the Upper Peninsula were relatively minor (fig. 16 $\mathrm{A}$, appendix 3A). Withdrawals before 1990 were estimated for facilities primarily in the Southern Lower Peninsula, owing to the relative lack of well-log data or knowledge of the years of operation of industrial facilities. Withdrawal estimates in the farfield model area consist almost entirely of data from industrial users in Monroe County and likely do not represent actual historical regional trends for the area of Michigan that is outside the LMB nearfield model area. For the last two time intervals, industrial groundwater withdrawals were primarily from the Quaternary aquifer system, with a somewhat

Table 10. Estimated amount of groundwater withdrawn for industrial use in part of Michigan that is released to recharge the groundwater system.

[Withdrawals are in million gallons per day; --, estimate not determined]

\begin{tabular}{lcccccccccccc}
\hline & \multicolumn{10}{c}{ Time interval } \\
\cline { 2 - 12 } & $\mathbf{1}$ & $\mathbf{2}$ & $\mathbf{3}$ & $\mathbf{4}$ & $\mathbf{5}$ & $\mathbf{6}$ & $\mathbf{7}$ & $\mathbf{8}$ & $\mathbf{9}$ & $\mathbf{1 0}$ & $\mathbf{1 1}$ & $\mathbf{1 2}$ \\
& $1864-1900$ & $1901-20$ & $1921-40$ & $1941-50$ & $1951-60$ & $1961-70$ & $1971-75$ & $1976-80$ & $1981-85$ & $1986-90$ & $1991-2000$ & $2001-5$ \\
\hline Estimated discharge water & -- & -- & -- & -- & -- & 7.85 & 5.73 & 5.76 & 6.6 & 7.45 & 8.18 & 10.14 \\
\hline
\end{tabular}




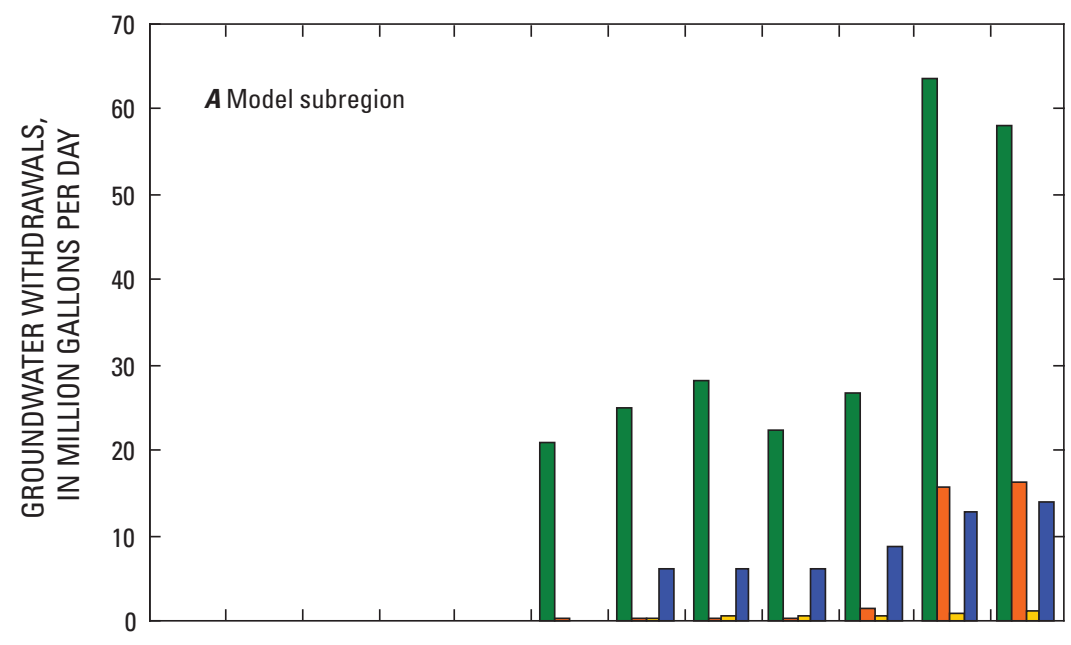

$\square$ Southern Lower Peninsula

$\square$ Northern Lower Peninsula

$\square$ Upper Peninsula

$\square$ Michigan farfield model area

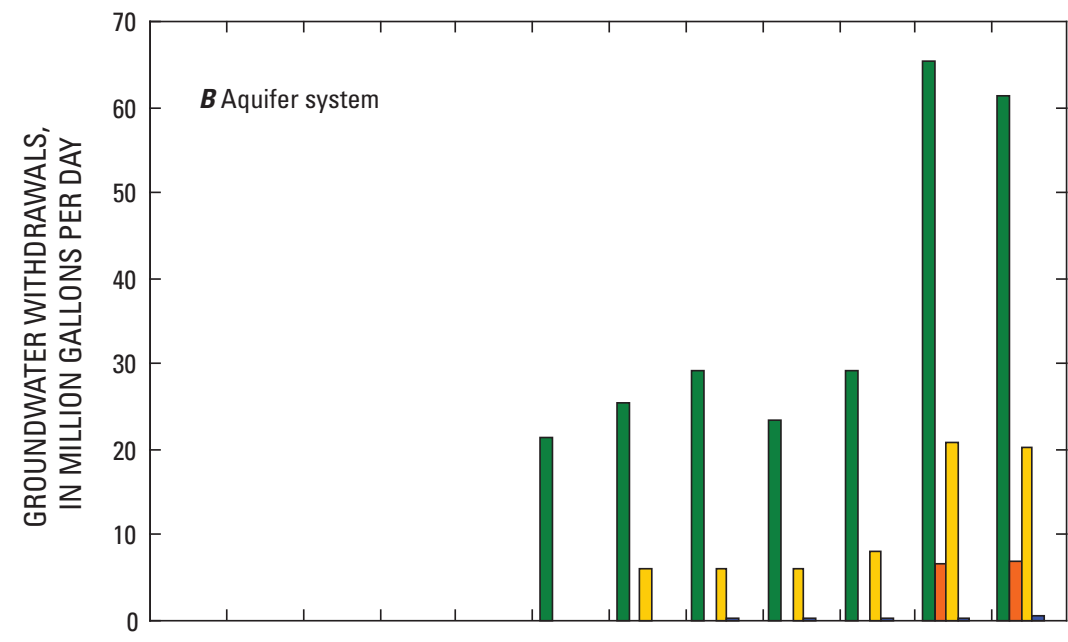

Quaternary

$\square$ Jurassic-Mississippian

$\square$ Silurian-Devonian

- Cambrian-Ordovician

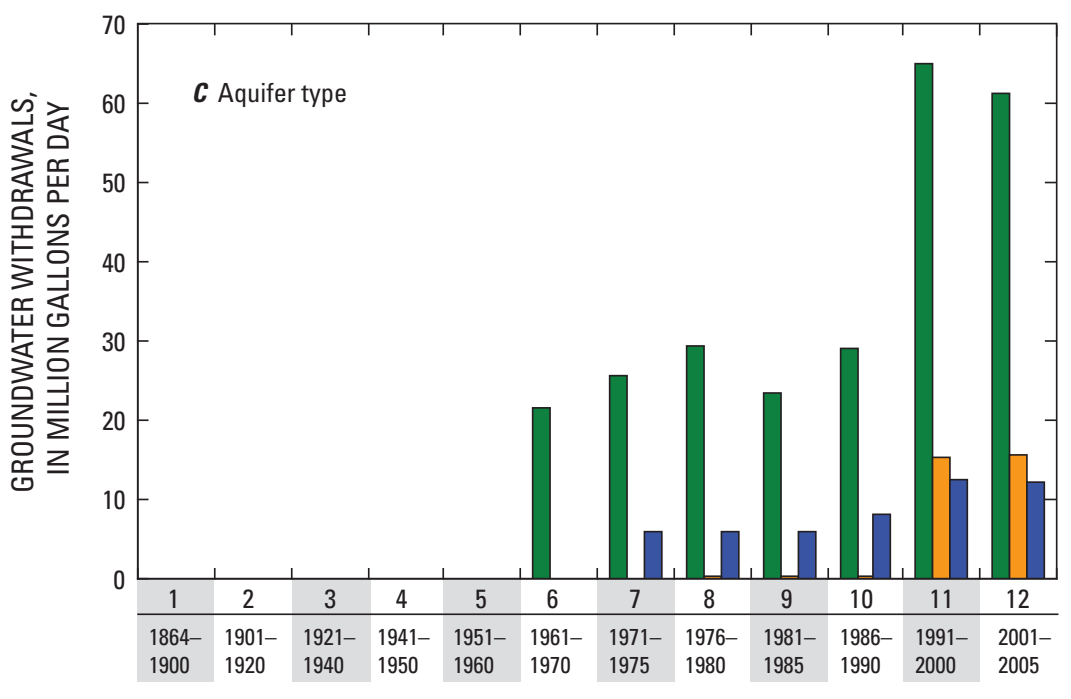

$\square$ Shallow unconsolidated material

$\square$ Shallow bedrock

Deep bedrock

TIME INTERVAL AND YEARS

Figure 16. Industrial groundwater-use estimates in Michigan for the Lake Michigan Basin model by time interval and $A$, model subregion, $B$, aquifer system, and $C$, aquifer type. Groundwater use for time intervals 6 to 10 is estimated and likely does not represent historical trends. Groundwater use was not estimated prior to time interval 6 because of the absence of data on withdrawal amounts and locations and on the years of operation of various industries. Values reflect only a partial estimate of water use in Michigan. 
lesser amount from the Silurian-Devonian aquifer system. Few withdrawals were from the Jurassic-Mississippian and Cambrian-Ordovician systems (fig. 16B, appendix 3B). For the last two time intervals, industrial groundwater withdrawals also were primarily from unconfined unconsolidated materials (fig. 16C, appendix 3C). Groundwater withdrawals before 1990 were estimated and may not represent the actual aquifer proportions.

\section{Additional Michigan Industrial Data Sources}

Water withdrawals for industrial use were estimated by using data from previous reports, the MDEQ Water-Use Reporting Program and GWIM Web sites, and the Wellogic database. During 1996-97, the MDEQ conducted a comprehensive survey to determine what proportion of the State's 17,000 manufacturing facilities are self-supplied, as opposed to receiving water from a public water-supply system. Survey results indicated that nearly 90 percent of the manufacturing facilities received water from a public water-supply system. Of the remaining self-supplied facilities, nearly 400 had the capacity for water withdrawals greater than the reporting threshold. The MDEQ receives water-withdrawal information from over 90 percent of these self-supplied facilities. Waterwithdrawal information is available by county for industrial water use starting in 1997 and continuing through 2004, the most recent year that data were available during this study (Michigan Department of Environmental Quality, 2004), whereas withdrawal data by facility (and not by well) were available for 2003 (Michigan Department of Environmental Quality, 2006c).

\section{Estimation Methods for Michigan Industrial Withdrawals}

The industrial water-use estimation method for Michigan was based largely on available withdrawal data for time intervals 11 and 12 (1991-2000 and 2001-5). For each county, the 2003 withdrawal data by facility were used to calculate the proportion of the county withdrawals for 2003. This proportion of withdrawals for 2003 by facility was then used to determine the facility withdrawals for other years that have withdrawal data by county. The reported data for 2003 included only the withdrawal location and no information about the well depth or aquifer. To determine the well depth and aquifer and to estimate the date withdrawals were initiated, the 2003 locational information was used to determine the closest well from the Wellogic database. For some facilities, multiple wells in the area were examined because of incomplete well-log data reporting. For facilities where the well-log data were incomplete, well depths and aquifer assignments were determined from information associated with nearby wells. The well-construction date was used to determine when pumping was initiated for the facility. Withdrawals before 1991 were estimated by using the trend observed from 1997 through 2004 and were estimated for each time interval back to the well-installation date for those locations for which a well was within $500 \mathrm{ft}$ of the industrial withdrawal location.
For those industrial withdrawal locations for which all local wells were greater than $500 \mathrm{ft}$ away, no withdrawals were estimated for time intervals before 1991. Therefore, industrial data estimated for this study indicate smaller withdrawals before 1985, but this result is an artifact of the estimation method and lack of data - it is not indicative of actual withdrawal trends (fig. 13). For example, the estimated withdrawal for interval 9 (1981-85) of $29.64 \mathrm{Mgal} / \mathrm{d}$ is only about half the reported withdrawal for 1982 of about $61 \mathrm{Mgal} / \mathrm{d}$ in "Water Use in Manufacturing" (U.S. Department of Commerce, 1982). Although these data are not directly comparable because the manufacturing census reported withdrawal is for all of Michigan, this comparison does illustrate that the modelestimated values are likely low for early intervals. However, early withdrawals for several counties with large withdrawals are accounted for, and missing withdrawals are likely small or widely dispersed and likely would have little impact on groundwater-flow-model water levels.

\section{Assumptions and Limitations of Michigan Industrial Data}

The groundwater withdrawals compiled and estimated for industrial use in the Michigan LMB model area include the assumption that estimates furnished by each facility are accurate, reliable, and consistent from year to year. Estimates determined for industrial facilities were based on 2003 locational information, and these locations were assumed to be accurate and inclusive of all or most industrial self-supplied locations. Only those facilities that meet the reporting-capacity threshold and were self-supplied were included in the data reported for 1997-2004. Because the majority of industries in Michigan are publicly supplied, most water withdrawals for industrial use already have been included in the public-supply category. A few estimates of water withdrawals for industrial water use were available from historical reports. These estimates typically were for local areas; however, some were more regional and likely included withdrawal data already incorporated for this study. These early reports did not give enough identifying information to easily locate the facility or to determine the source of water. Additionally, no information is available on when withdrawals were initiated or how long withdrawals occurred, so most of these data could not be included in this study, and no estimates for those facilities were derived for this study. Therefore, estimated industrial withdrawals before 1985 likely underestimate actual historical withdrawals because of a lack of data; thus, the trend shown for these data is not indicative of historical industrial withdrawals in the Michigan LMB model area.

Because the reported data for 2003 did not include individual well data, the estimated aquifer information is assumed to be approximated correctly by using local nearby wells. Likewise, the estimated data are based on the assumption that pumping began when the well was installed and that pumping follows the trends reported for 1997-2004. Estimates for each year also are based on the assumption that the withdrawal location and sources did not change over time and that the 
proportions can be approximated as described above. Withdrawals that occur within the farfield model area were, for the most part, not included in this compilation, although the impact of these is expected to be small and to have little effect on water levels in the LMB nearfield model area. However, these omissions could affect inset-model results if any local models are placed in this area.

\section{Irrigation Water Use in Michigan}

In Michigan, irrigation water uses include withdrawals for agriculture and golf courses. Agriculture is a major contributor to Michigan's economy even though many changes in non-farm factors, technology, and economic conditions have affected Michigan farms over time. From 1950 to 1987, the number of farms generally declined whereas overall farm size increased. However, with the decrease in total farmland, the percentage of irrigated land increased over the same time period (Michigan State University Extension, 1998). The artificial application of irrigation water to crops is widely practiced in Michigan and permits growers to have greater control over the timing and amount of water applied throughout the growing season (Michigan Department of Environmental Quality, 2006b). The artificial application of irrigation water to golf courses permits the maintenance of healthy turf grasses and improves the recreational value of golf course lands (Michigan Department of Environmental Quality, 2006d). Irrigation water use can vary considerably in response to weather conditions, the availability of adequate water supplies, and basic management decisions made by irrigators, in addition to water needs of specific crop types or golf course characteristics.

The availability of agricultural census and precipitation data, along with crop moisture requirements, allows for estimation of historical agricultural irrigation water use; however, historical data on water withdrawal amounts for golf course irrigation were unavailable. Irrigation water-use estimates for the Michigan part of the LMB model area were calculated differently for these two types of irrigation uses. Agriculture water-use estimates were determined only for those counties with the largest groundwater withdrawals because of the complexity of the estimation method. Groundwater withdrawals in the following 11 counties accounted for 79 percent of total agricultural irrigation-water withdrawals in Michigan in 2004: Allegan, Berrien, Branch, Calhoun, Cass, Kalamazoo, Kent, Montcalm, Ottawa, St. Joseph, and Van Buren (figs. 10 and 11). Withdrawals in counties other than those listed above are expected to have only a local impact on water levels.

Because of a lack of data on withdrawal amounts or locations, no withdrawals were estimated for time intervals before 1920 (interval 3) for agricultural use. For interval 3 to interval 12 (1921-2005), agricultural groundwater-use data were estimated for 11 counties in the LMB model area.

Well logs are coded for well type, including irrigation, but the type of facility or the way the well is used is not specified. Therefore, irrigation wells could be for farms, nurseries, cemeteries, facility lawns, golf courses, or other uses. In addition, owner information is sometimes incomplete, or facilities are listed under the owner name with no mention of the facility. Of the approximately 4,000 well logs identified as for irrigation, only 95 listed a golf course or country club as the well owner, with the earliest well-log dated 1967. Because of the uncertainty in associating withdrawal data from 1997-2004 with an irrigation well and the lack of information on the golf course size or number of irrigated acres, no golf course withdrawals were estimated for time intervals before 1991 (interval 11). Withdrawals for golf course use were likely small before 1990 and probably had only a local impact on water levels. For intervals 11 (1991-2000) and 12 (2001-5), groundwateruse data were estimated for 210 golf course facilities, primarily in counties in the Michigan LMB model area.

Estimated irrigation withdrawals in the Michigan LMB model area equal $0.08 \mathrm{Mgal} / \mathrm{d}$ for interval 3 (1921-40) and $111.38 \mathrm{Mgal} / \mathrm{d}$ for interval 12 (2001-5) (table 4). These withdrawals are exclusively for agricultural uses in intervals 3 through 10 (1921-1990) and combine agricultural and golf course uses for intervals 11 and 12 (1991-2005). Estimated withdrawals for agricultural uses account for over 85 percent of the total irrigation withdrawals for intervals 11 and 12 . Groundwater withdrawals for agricultural irrigation were estimated exclusively for selected counties in the Southern Lower Peninsula, and groundwater withdrawals for golf course irrigation were estimated for the Lake Michigan Basin and several adjacent counties for the last two time intervals. Irrigation withdrawals are primarily from the Southern Lower Peninsula, with only minor withdrawals from the Northern Lower Peninsula and farfield model area in the last two time intervals (fig. 17A, appendix $3 A$ ). About 71 percent of the groundwater withdrawn for golf course irrigation and 79 percent of the groundwater withdrawn for agricultural irrigation in Michigan was withdrawn by those counties for which data were estimated in the LMB model area. Irrigation groundwater withdrawals were primarily from the Quaternary aquifer system; few withdrawals were from the deeper Jurassic-Mississippian, Silurian-Devonian, and Cambrian-Ordovician aquifer systems (fig. 17B, appendix $3 B$ ). Irrigation groundwater withdrawals were primarily from unconfined unconsolidated material (fig. $17 C$, appendix $3 C$ ). Very few irrigation withdrawals were from deep confined bedrock wells.

\section{Additional Michigan Irrigation Data Sources}

Water-use estimates for agricultural irrigation in Michigan were determined for time intervals 3 to 10 (1921-90) by using data from published Census of Agriculture reports, an irrigation scheduler model, and records maintained by the MDEQ for 11 Michigan counties within the Lake Michigan Basin. Water withdrawals for agricultural irrigation for intervals 11 and 12 (1991-2005) were estimated from data for 1997-2004 (Michigan Department of Environmental Quality, 2005a). Water-use estimates for golf course irrigation for intervals 11 and 12 (1991-2005) were estimated from data for 

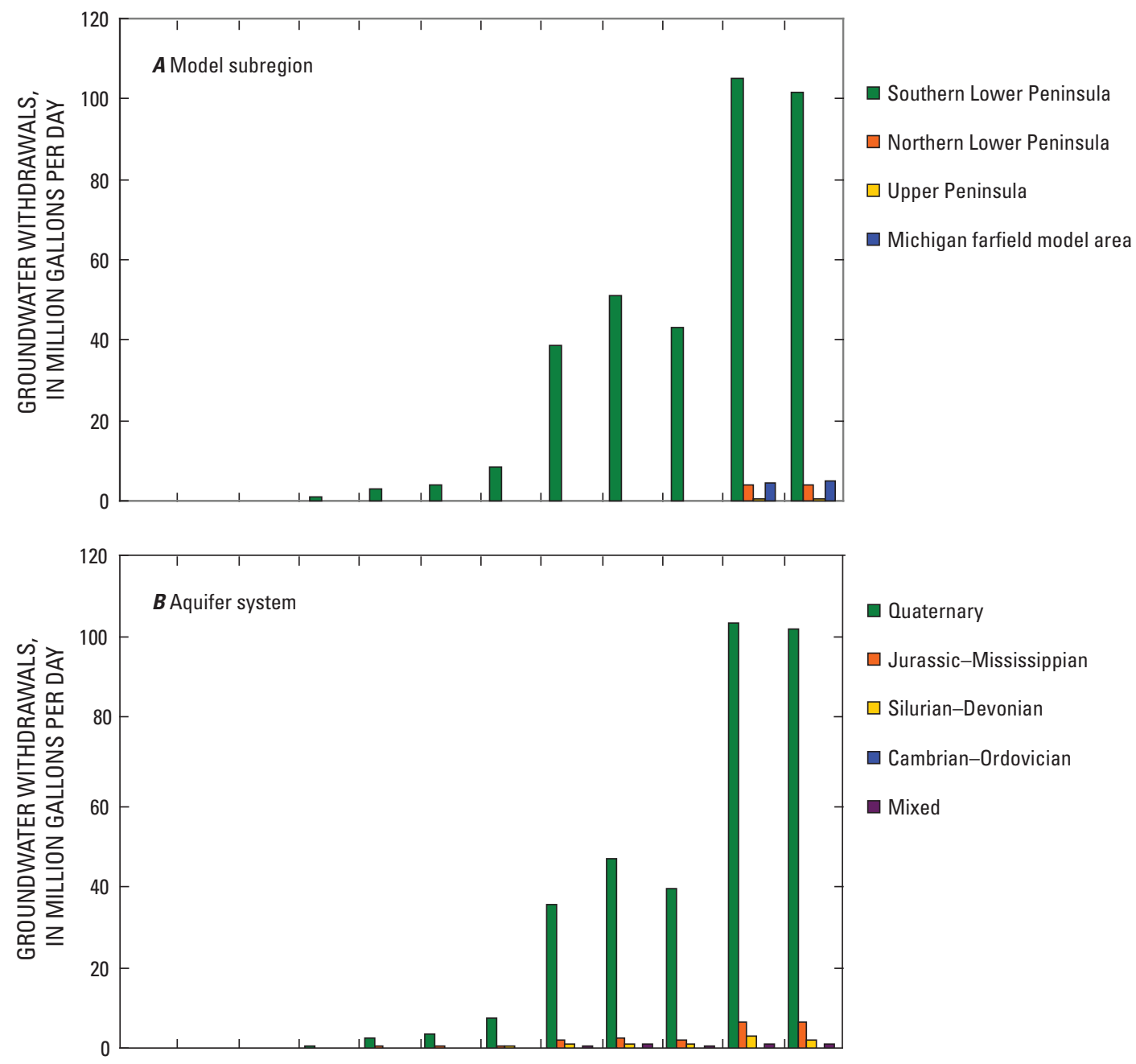

$\square$ Quaternary

$\square$ Jurassic-Mississippian

$\square$ Silurian-Devonian

$\square$ Cambrian-Ordovician

Mixed

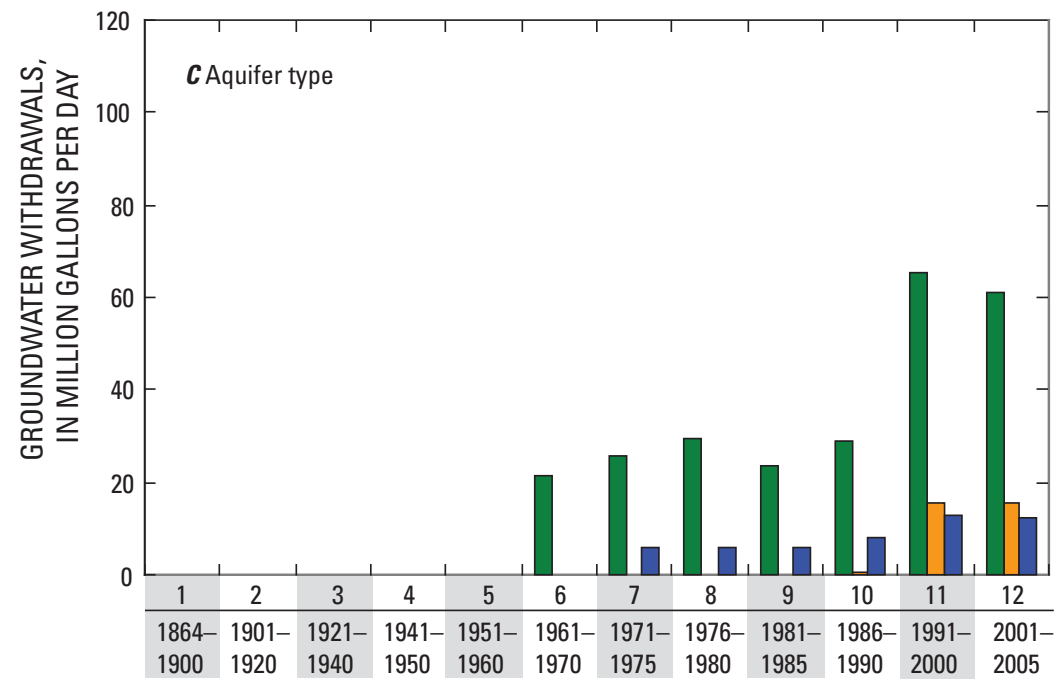

Shallow unconsolidated material

$\square$ Shallow bedrock

Deep bedrock

TIME INTERVAL AND YEARS

Figure 17. Irrigation groundwater-use estimates in Michigan for the Lake Michigan Basin model by time interval and $A$, model subregion, $B$, aquifer system, and $C$, aquifer type. Groundwater use for time intervals 3 to 10 is estimated and likely does not represent historical trends. Groundwater use was not estimated for agricultural irrigation prior to time interval 3 or for golf course irrigation prior to time interval 11 because of a lack of data. Therefore, estimates for time intervals 3 to 10 include agricultural use only; estimates for time intervals 11 and 12 include agricultural and golf course uses. Values reflect only a partial estimate of water use in Michigan. 
1997-2004 from the MDEQ Water-Use Reporting Program (Michigan Department of Environmental Quality, 2005a) and GWIM Web sites (Michigan Department of Environmental Quality, 2006c) and the Wellogic database.

Census of Agriculture farm and crop data (U.S. Department of Commerce-Bureau of the Census, 1927, 1932, 1942, 1946, 1952, 1956, 1961, 1967, 1971, 1977, 1982, 1984, 1990) were entered into a spreadsheet database for selected Michigan counties within the Lake Michigan Basin. Farm data were presented in units of acres and included the area of all land in farms, cropland, pastureland, woodland not used for pasture, all other land in farms, and irrigated land (which was reported as a single number representing both cropland and pastureland combined). Irrigated land was not reported for censuses before 1940. Crop data also were presented in acres, and only crop types used for the irrigation scheduling program were entered into the spreadsheet database. Because the census reports included data from the previous census year, values for both census years from each report were input to ensure data quality. All differences between census reports were explored and noted or corrected. Overall, for each county, acreage irrigated appears to have increased over time even as total acreage of cropland decreased over time.

The Census of Agriculture data are reported by county; therefore, a method was needed to distribute the estimated agricultural withdrawals within each county. Large-scale survey section maps for the 11 focus counties were printed and compared against aerial photograph indexes for the 1938, $1955,1967,1974,1981$, and 1992 or 1998 photograph years. Each survey section covered an approximately $1-\mathrm{mi}^{2}$ area and was noted as being either predominantly agricultural or not during each of the photograph years. Information on these areas that were delineated as likely being agricultural was input later into a GIS so it could be used when determining the geographic areas where irrigation-withdrawal estimates could best be concentrated. It was noted that, over time, the same decrease in total cropland reported in the Census of Agriculture also was apparent in the photograph data.

In order to determine the amount of water needed to produce the crops reported in the Census of Agriculture, an irrigation scheduling program was used. This program was developed through the Agricultural Engineering Department at Michigan State University (MSU) (Shayya and Bralts, 1994) and is run as a Microsoft Excel spreadsheet macro. This program uses crop type, the crop emergence date, length of the growing season, soil type, and climate data (temperature and precipitation) to estimate the amount of water (in inches) needed for a particular crop and the appropriate schedule for when a field would need to be irrigated. For this study, determining when to irrigate was not the focus; rather, the emphasis was on the total volume of water that was applied over the growing season (and later distributed annually for the model datasets).

Crop types that can be modeled with the irrigation scheduling program are corn, potatoes, soybeans, dry edible beans, and alfalfa. The emergence date and length of the growing season depend on the crop type. The dates and growing season lengths used were based on average climate conditions and agricultural practices (table 11; Steve Miller, Michigan State University Department of Agricultural Engineering, oral commun., August 2007). Knowledge of the crop type also was translated into the crop profile effective rooting depth (table 12) and into the minimum soil moisture content (also referred to as the maximum allowable depletion; table 13). The crop profile effective rooting depth for corn was also used for alfalfa because of similarities in the rooting structure between the two plants (Joe Duris, U.S. Geological Survey Michigan Water Science Center, oral commun., August 2007). The irrigation scheduling program uses the data described above to estimate the soil water that would be available in the crop root zone for the particular time period being estimated. As the growing season progresses, the program accounts for the increasing root depth in computing the estimate of crop water demand.

Table 11. Emergence dates and length of growing season used in the irrigation scheduling program.

\begin{tabular}{|c|c|c|}
\hline Crop type & Emergence date & $\begin{array}{l}\text { Length of growing } \\
\text { season (days) }\end{array}$ \\
\hline 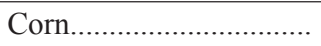 & May 15 & 120 \\
\hline Potatoes............................. & June 1 & 70 \\
\hline 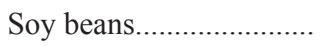 & June 1 & 120 \\
\hline Dry beans......................... & June 1 & 120 \\
\hline Alfalfa................................. & May 1 & 120 \\
\hline
\end{tabular}

Table 12. Effective rooting depth, by crop, provided as defaults used in the irrigation-scheduling program.

\begin{tabular}{|c|c|}
\hline Crop type & Effective rooting depth (feet) \\
\hline Corn.................. & 2.5 to 4 \\
\hline Potatoes.............. & 1.5 to 2 \\
\hline Soy beans.... & 1.5 to 2 \\
\hline Dry beans.... & 1 to 2 \\
\hline 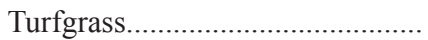 & 0.5 to 1.5 \\
\hline
\end{tabular}

Table 13. Maximum allowable depletion, by crop type.

[From Bauder and Carlson, 2005]

\begin{tabular}{|c|c|}
\hline Crop type & $\begin{array}{l}\text { Depletion allowance } \\
\text { (percent) }\end{array}$ \\
\hline 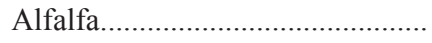 & 65 \\
\hline 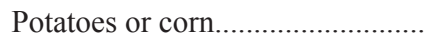 & 40 \\
\hline 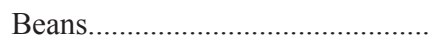 & 40 \\
\hline
\end{tabular}


The soil types used in the program were determined by using the 1:250,000 State Soil Geographic database (STATSGO) published by the U.S. Department of Agriculture, Soil Conservation Service (1994), and were translated into default values for the available soil moisture (table 14). By using a GIS, soil data, and the previously described aerial photo survey sections, areas of interest were analyzed to account for the changing acreage of cropland and the distribution of cropland across each county along with soil type. For the irrigation scheduler program, only the two primary soil types were included in the analysis if they represented at least 80 percent of the total agricultural land. If the combined two soil types represented less than 80 percent of the total agricultural land, the third most prevalent soil type was included in the analysis.

Climate data were downloaded from the National Climatic Data Center (2005) for each of the 11 focus counties. These data included temperature (as minimum, maximum, and observed, in degrees Fahrenheit) and precipitation (as hundredths of inches) at selected climate observation stations. These observation locations and the period of record available varied from county to county. A description of the observations that were used is presented in table 15. Observed temperature data were missing for the 1930, 1940, 1945, 1950, and 1955 census years for Calhoun County and for all census years in Kent County. The average of the minimum and maximum temperatures for each day for each of these two counties within these years was used in place of the observed temperature data. Additionally, because of a gap in climate data for Kent County for 1930, 1935, and 1940, irrigation models were not run for these model years.

\section{Estimation Methods for Michigan Agricultural Irrigation Withdrawals}

The approach described above resulted in just greater than 1,700 irrigation estimates for each different combination of county, crop and soil type, and census date. Each model run within the irrigation scheduling program resulted in a total irrigation estimate in inches of water that was applied over the growing season. To convert inches of water applied onto the irrigated acres reported in the Census of Agriculture into withdrawal units of million gallons per day, the equation displayed below was used:
Table 14. Default values for the available soil moisture for various soils used in the irrigation-scheduling program.

\begin{tabular}{|c|c|}
\hline Soil type & $\begin{array}{c}\text { Soil moisture } \\
\text { (inches per foot) }\end{array}$ \\
\hline 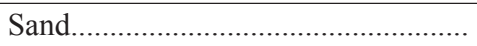 & 0.5 \\
\hline 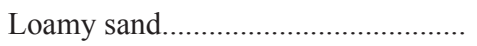 & 1 \\
\hline 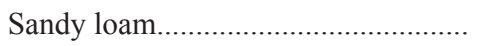 & 1.5 \\
\hline 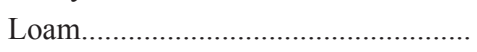 & 2 \\
\hline 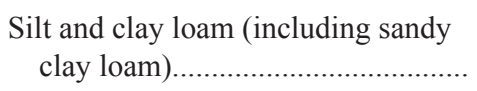 & 2.5 \\
\hline Clay........................ & 2 \\
\hline
\end{tabular}

These estimates were averaged for the census years corresponding to the time intervals used in the LMB model. Irrigation water use was estimated for each growing season, which was approximately a 70- to 120-day period. No water was withdrawn for irrigation during the other months of the year. However, in order to represent these estimates of irrigation water use as an annual rate assuming steady year-round pumping and to account for possible years in which the modeled crop type was not grown due to crop rotations, each seasonal daily estimate was divided by 4 to get a representative annual daily rate (presuming there are 4 seasons in the year). Table 16 outlines the irrigation-estimate years and the aerial-photograph years (used in determining where to distribute the irrigation estimate across each county) matched to the model time intervals.

For the 11 counties in this analysis, well data stored within the Wellogic database were extracted. Within the extraction, the oldest well dates from 1954, whereas irrigated acres have been reported in the Census of Agriculture since 1940. Also, because the true distribution of irrigated acres across each county is unknown, agricultural survey sections identified through aerial photographs were used. Working county by county with a GIS, the LMB model finite-difference grid was overlaid against the agricultural survey sections by year, and the intersecting centroids of the grid cells were identified. Because this produced far more points than needed, the ratio of total irrigated acres versus the total acres of cropland reported was used to scale down the number of points used.

\begin{tabular}{|c|c|c|c|c|}
\hline Irrigation & Area of & & & \\
\hline $\begin{array}{l}\text { applied } \\
\text { (inches) }\end{array}$ & $\begin{array}{l}\text { soil type } \\
\text { (acres) }\end{array}$ & \multirow{3}{*}{ Crop area (acres)> } & $\begin{array}{l}27,154 \\
\text { gallons }\end{array}$ & $1 \mathrm{Mgal}$ \\
\hline ength of & Total soil & & $\times \frac{\overline{1 \text { acres }}}{1}$ & $\frac{1,000,000}{1,0}$ Total irrigation applied $(\mathrm{Mgal} / \mathrm{c}$ \\
\hline rowing & area & & - inch & gallons \\
\hline
\end{tabular}

season (days) (acres) 
Table 15. County and climate-observation station name and time period of temperature and precipitation data used in the irrigationscheduling program.

[Data from the National Climatic Data Center, 2005; -- data not available]

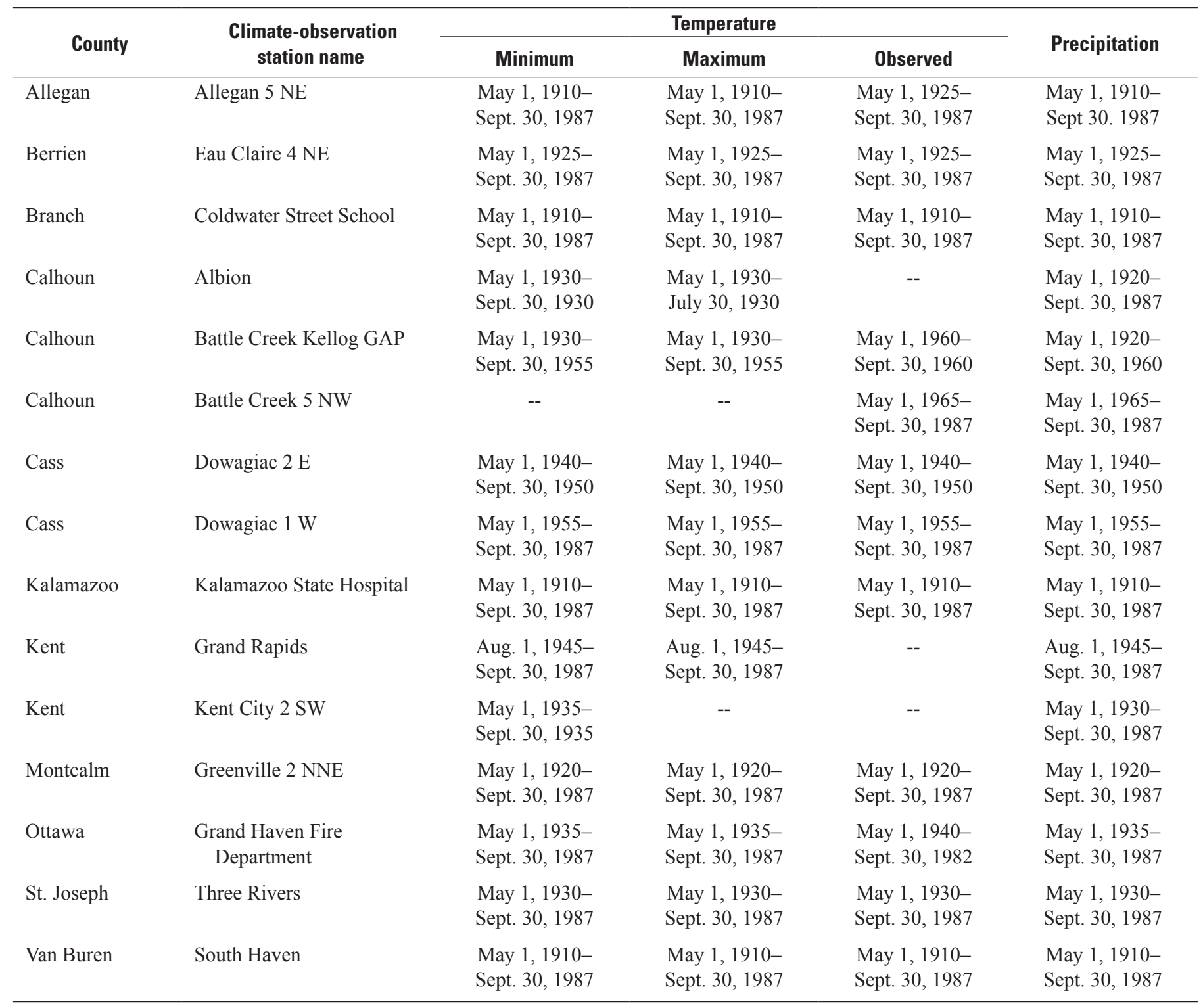

Working through each time interval, points were selected on the basis of their proximity to actual irrigation-well locations (regardless of construction year, though priority was placed on the oldest wells). The irrigation estimate was assigned to each point for the interval being reviewed, and the nearby irrigation-well characteristics (well depth, casing depth, screened interval, well lithology of either unconsolidated materials or bedrock, and surface elevation) also were applied to each point. If no irrigation wells were within a 1-mi radius of the point (approximated from the survey sections), the characteristics from a nearby domestic well were applied. If there were several wells to choose from, then the characteristics that best resembled the closest irrigation well were used. In all cases, the corresponding well identification number also was assigned to each point so that this assignment could be traced back to the original well file. Every effort was made to ensure that well characteristics were not applied to more than one grid centroid within each time interval. However, the well characteristics were moved to a different centroid if the cell that was originally used ceased at some time to be agricultural.

Irrigation water use for intervals 11 and 12 (1991-2000 and 2001-5) was not determined by using the irrigation scheduling program because these estimates already were available directly from the MDEQ (2006b). However, the process described above was used to assign these estimates to the centroid points used. Because these values represented the irrigation total directly, the irrigated acres versus acres of cropland were not immediately known. Therefore, the same 
Table 16. Irrigation-estimate and aerial-photograph years matched to each model time period.

\begin{tabular}{|c|c|c|c|c|}
\hline Model time period & $\begin{array}{c}\text { Irrigation-estimate years } \\
\text { (Agriculture census } \\
\text { years) }\end{array}$ & Aerial photograph year & Source agency ${ }^{1}$ & $\begin{array}{l}\text { Photograph } \\
\text { scale }\end{array}$ \\
\hline $1864-1900$ & -- & -- & & \\
\hline $1901-20$ & -- & -- & & \\
\hline \multirow[t]{4}{*}{$1921-40$} & 1925 & 1938 & \multirow{5}{*}{ 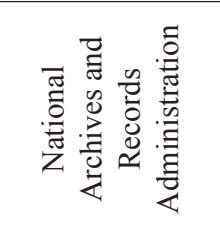 } & $1: 20,000$ \\
\hline & 1930 & & & \\
\hline & 1935 & & & \\
\hline & 1940 & & & \\
\hline \multirow[t]{2}{*}{$1941-50$} & 1945 & 1938 & & $1: 20,000$ \\
\hline & 1950 & 1955 & \multirow{14}{*}{ 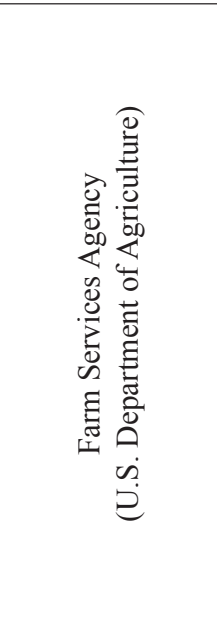 } & $1: 20,000$ \\
\hline \multirow[t]{2}{*}{$1951-60$} & 1955 & 1955 & & $1: 20,000$ \\
\hline & 1960 & & & \\
\hline \multirow[t]{2}{*}{$1961-70$} & 1965 & \multirow[t]{2}{*}{1967} & & \multirow[t]{2}{*}{$1: 20,000$} \\
\hline & 1970 & & & \\
\hline $1971-75$ & 1975 & 1974 & & $1: 40,000$ \\
\hline $1976-80$ & 1978 & 1974 & & $1: 40,000$ \\
\hline $1981-85$ & 1982 & 1981 & & $1: 58,000$ \\
\hline $1986-90$ & 1987 & 1981 & & $1: 58,000$ \\
\hline \multirow[t]{4}{*}{$1991-2000$} & *1997 & \multirow[t]{4}{*}{$1992 / 1998$} & & \multirow[t]{4}{*}{$1: 40,000$} \\
\hline & *1998 & & & \\
\hline & *1999 & & & \\
\hline & $* 2000$ & & & \\
\hline $2001-9$ & $*$ & 1992/1998 & & $1: 40,000$ \\
\hline
\end{tabular}

number of points calculated for interval 10 (1986-90) was used. The 1991-2000 data were distributed to the sections identified as being agricultural by using either the 1992 or 1998 aerial photographs. Data for interval 12 (2001-5) were received as a GIS layer subdivided by township. This dataset was intersected with the 1992/1998 agricultural sections, and the overlapping townships were selected. The point locations used for interval 11 (1991-2000) that intersected the selected townships were chosen. The total irrigation reported for each township was divided by the number of points selected, and that average was assigned to each of the selected points. Once the well characteristics and irrigation estimates were applied, all of the model centroids used in this analysis were selected and subset into a stand-alone GIS shapefile.

\section{Estimation Methods for Michigan Golf Course Irrigation Withdrawals}

Golf course irrigation water-use estimates were determined from available data for each county for intervals 11 and 12 (1991-2000 and 2001-5). The average withdrawals for each time interval for each county were applied to each location according to the proportions reported for each facility in the county for 2003 on the basis of data from the GWIM Web site (Michigan Department of Environmental Quality, 2006c). The reported data for 2003 included only the withdrawal location and no information about the well depth or aquifer. To determine the well depth and aquifer, the 2003 locational information was used to determine the closest well from the Wellogic database. For some facilities, multiple wells in the area were examined because of incomplete well-log data reporting. For facilities where the well-log data were incomplete, well depths and aquifer assignments were determined from information associated with nearby wells. In most instances, the nearest well was coded as being a type other than irrigation. Because this resulted in considerable uncertainty when extending these estimates earlier than the reported withdrawal years, such estimates were not made for years before 1990. Golf course irrigation data estimated for this study indicate no withdrawals before 1990 because of the estimation method and lack of data and are not indicative of actual withdrawal trends (fig. 13). 


\section{Assumptions and Limitations of Michigan Irrigation Data}

Many limitations and assumptions are involved in this approach to estimate agricultural irrigation water use. Census of Agriculture data are limited to the methods used to collect and report the data and the way in which the data were distributed across each county. The assignment of expected agricultural water use to sections from the aerial-photograph analysis was limited by the interpretation of the analyst, the scale and quality of the photographs, and the lack of photographs representing time intervals before 1938. The irrigation scheduling program was limited to the five crop types analyzed by the program and included the assumptions that (1) the crop yield each year was 100 percent and (2) the crop emergence date and growing season matched the average value for each crop every census year. Use of the climate data from each station was based on the assumption that these data adequately represented climate conditions throughout the entire county. The base soil data are not meant to be used at the scale used in this analysis, though they are the most detailed data currently available. The textures used are those coarsely assigned on the basis of soil families and were not checked against countylevel soil surveys. By using this crop-demand approach, the assumption is made that all irrigation waters are supplied from groundwater sources and not supplemented by surface-water sources. Lastly, the assumption also is made that the irrigation is optimally applied and measured exactly as modeled by the farmer overseeing the irrigator operations, and that the expected crop yield is 100 percent. Realistically, the farmer may irrigate the field on a time basis, and the expected crop yield may be lower. Water use for intervals 11 and 12 (19912000 and 2001-5) was estimated by the MDEQ, who used a different program than was used for the earlier intervals; therefore, these estimates likely differ in their completeness and may not be directly comparable, although both are assumed to adequately estimate agricultural irrigation water use. Agricultural irrigation withdrawals determined by using the irrigation scheduling program in this study and the estimates determined by the MDEQ were assigned to locations on the basis of existing irrigation or nearby wells and areas determined to be agricultural through aerial photo interpretation. Although assumed to be representative for the purposes of the LMB model, these irrigation water-use estimates should not be used in a localscale study without further consideration.

The self-supplied golf course water-use estimates compiled and estimated for this study are based on the assumption that estimates furnished by each facility are accurate, reliable, and consistent from year to year. Estimates were determined for facilities listed as irrigators in 2003. Only those facilities that meet the reporting-capacity threshold and are selfsupplied are included in the data reported for 1997-2004, and no estimates were compiled for years before 1991 because of a lack of data. The trend shown for the data is not indicative of actual golf course irrigation withdrawals in the included counties. However, some water withdrawals for golf course use already have been included in the public-supply estimate.
About 35 percent of the golf courses in the State are supplied by a public water-supply system, have a withdrawal capacity less than the reporting threshold for irrigation water use, or do not irrigate at all (Michigan Department of Environmental Quality, 2006d). Because the reported data for 2003 did not include individual well data, the estimated aquifer information is assumed to be approximated correctly by using information from local nearby wells. Estimates for each year also are based on the assumption that the location of withdrawals and sources did not change over time and that the proportions can be approximated as described above. Withdrawals that occur in counties other than those listed above were, for the most part, not included in this compilation, although the impact of these is expected to be small and to have little effect on the groundwater-flow-model water levels in the nearfield model area or primary area of interest in the basin. However, these omissions and the method of assignment of withdrawals to locations could affect inset-model results if any local models are placed in this area.

\section{Indiana}

\section{History of Groundwater Management and Water- Use Data Collection in Indiana}

The Indiana Department of Natural Resources (IDNR), Division of Water, has been inventorying the State's significant water withdrawal facilities since 1985 and collecting monthly withdrawal data for the categories described in table 1 . In Indiana, a "significant water withdrawal facility" is defined as having the capability to withdraw $100,000 \mathrm{gal} / \mathrm{d}$ or more of water from a groundwater or surface-water source. (For this report, only groundwater data were included.) This reporting requirement was mandated by the Water Resource Management Act (Indiana Code 14-25-7, previously 13-2-6.1) and passed by the State Legislature in 1983. Registration and reporting requirements are based on pump capacity, not actual water withdrawals. Each year, registered facility owners report total monthly withdrawals based on flowmeter readings, pump capacity and hours of operation, or some other alternative estimation technique. In 1996, withdrawal data were reported for 3,536 active registered facilities (Arvin and Spaeth, 2009). In 2004, withdrawal data were reported for 3,409 active registered facilities.

Information on water resources in Indiana is available from individual county investigations and basin to statewide studies. In addition to the inventory of water withdrawals, the Water Resource Management Act mandates a continuing assessment of water-resource availability in the State and plans for the development, conservation, and utilization of the water resources for beneficial uses. To help assess water availability, the Natural Resources Commission has divided the State into 12 water management basins in which the IDNR Division of Water characterizes the water resource on and below the Earth's surface. Four of these water management 
basins include counties within the Indiana LMB model area (Indiana Department of Natural Resources, 1987, 1990, 1994, and 1996). The IDNR has prepared a Generalized Groundwater Availability Map (Indiana Department of Natural Resources, 2009a) that describes seven groundwater-yield categories and indicates a measure of the relative productivity of the depicted aquifers. Detailed studies would be necessary to adequately evaluate the groundwater resource and the probable impacts of pumping in an area.

\section{Overview of Indiana Data From the Lake Michigan Basin Study}

The Indiana part of the LMB model area consists of 11 counties in the Northern Indiana subregion, all of which have at least some part within the Lake Michigan Basin boundary: Allen, Dekalb, Elkhart, Kosciusko, Lagrange, Lake, La Porte, Noble, Porter, St. Joseph, and Steuben (fig. 10). Water use in the Indiana farfield area consists of only those parts of the above-listed counties that are outside of the nearfield model area. Therefore, Indiana water-use estimates are primarily within the nearfield model area (table 2). Overall, a total of 2,002 withdrawal locations were estimated for counties within the Indiana LMB model area, and 1,104 locations were active in the last model time interval (2001-5) for a total withdrawal of $128.3 \mathrm{Mgal} / \mathrm{d}$ (table 2).

In general, northern Indiana can be characterized as having a good to excellent groundwater resource. Major areas of groundwater availability are found where the SilurianDevonian bedrock aquifer system unit underlies large areas and where Quaternary deposits of glacial material as much as $500 \mathrm{ft}$ in thickness contain highly productive inter-till sand and gravel aquifers (Indiana Department of Natural Resources, 2009a). The Jurassic-Mississippian and Cambrian-Ordovician aquifer systems are not used for water supply in northern Indiana.

Total withdrawals for the nearfield model area range from $0.21 \mathrm{Mgal} / \mathrm{d}$ in interval $3(1921-40)$ to $117.42 \mathrm{Mgal} / \mathrm{d}$ in interval 12 (2001-5), and withdrawals from the farfield model area range from $0 \mathrm{Mgal} / \mathrm{d}$ in interval 3 to $10.88 \mathrm{Mgal} / \mathrm{d}$ for interval 12 (table 2). No withdrawals were estimated for the first two time intervals because of a lack of data. It should be emphasized that water-use estimates were compiled primarily for counties within the LMB nearfield model area and that these estimates do not represent the total amount of groundwater withdrawn in Indiana for these categories.

An analysis to quantify withdrawals omitted from model simulations for counties excluded from the Indiana farfield model area (Adams, Fulton, Huntington, Jasper, Marshall, Miami, Newton, Pulaski, Starke, Wabash, Wells, and Whitley) showed that omission of these withdrawals would likely have little effect on model results; the majority of withdrawals are from the shallow unconsolidated and bedrock aquifer types, so drawdowns are expected to have little influence on the exchange of water between the model farfield and nearfield areas (Daniel Feinstein, U.S. Geological Survey Wisconsin Water Science Center, oral commun., 2008). In 2001-5, groundwater withdrawals of $128.30 \mathrm{Mgal} / \mathrm{d}$ were reported for counties in the Lake Michigan Basin, with $124.78 \mathrm{Mgal} / \mathrm{d}$ from unconsolidated aquifers and $3.52 \mathrm{Mgal} / \mathrm{d}$ from bedrock aquifers (table 5). Groundwater withdrawals of $43.04 \mathrm{Mgal} / \mathrm{d}$ were reported in 2004 for the farfield counties not included in the LMB model analysis, with $30.39 \mathrm{Mgal} / \mathrm{d}$ from unconsolidated aquifers, $11.52 \mathrm{Mgal} / \mathrm{d}$ from bedrock aquifers, and $1.13 \mathrm{Mgal} / \mathrm{d}$ from unknown aquifer sources.

\section{Principal Indiana Data Sources}

The IDNR Division of Water's Water Rights and Use Section maintains the Significant Water Withdrawal Facility (SWWF) database and the Online Water Well Database (Indiana Department of Natural Resources, 2009b). Water-use data from the SWWF database included location and facility data fields, well depth, well diameter, aquifer, water-use category, and monthly and annual water withdrawal amounts for 1985 to 2005 (Ralph Spaeth, Indiana Department of Natural Resources, written commun, 2006). Reported aquifer and well-construction information was used to determine the hydrologic unit that withdrawals tapped. Water-use information was available or estimated for the public-supply, industrial, and irrigation report-specific categories (table 1). Additional well-construction details, including construction dates, were retrieved from the Online Water Well Database and were helpful for determining when the well became active.

Population data for publicly supplied communities within the selected counties were compiled from U.S. Bureau of the Census reports. In the selected counties, at least some population data were reported for 82 communities from 1880 to 2000 . The population data indicate an upward trend until about 1960, after which population remains relatively constant (fig. 18); however, no population was reported for many communities before 1930, possibly because they had not been incorporated yet. For 1970 until 2000, data were unreported for only two communities. In 1880, population was reported for 40 communities compared to 81 in 2000. Arvin and Spaeth (2009) report an increase in population for the entire State of Indiana from 3.24 million people in 1930 to more than 5.80 million people in 1995, a greater than 79-percent increase in 65 years. Available data for the selected 11 counties in Northern Indiana indicate a population increase from 0.82 million people in 1930 to more than 1.75 million people in 2000, an increase of greater than 112 percent. 


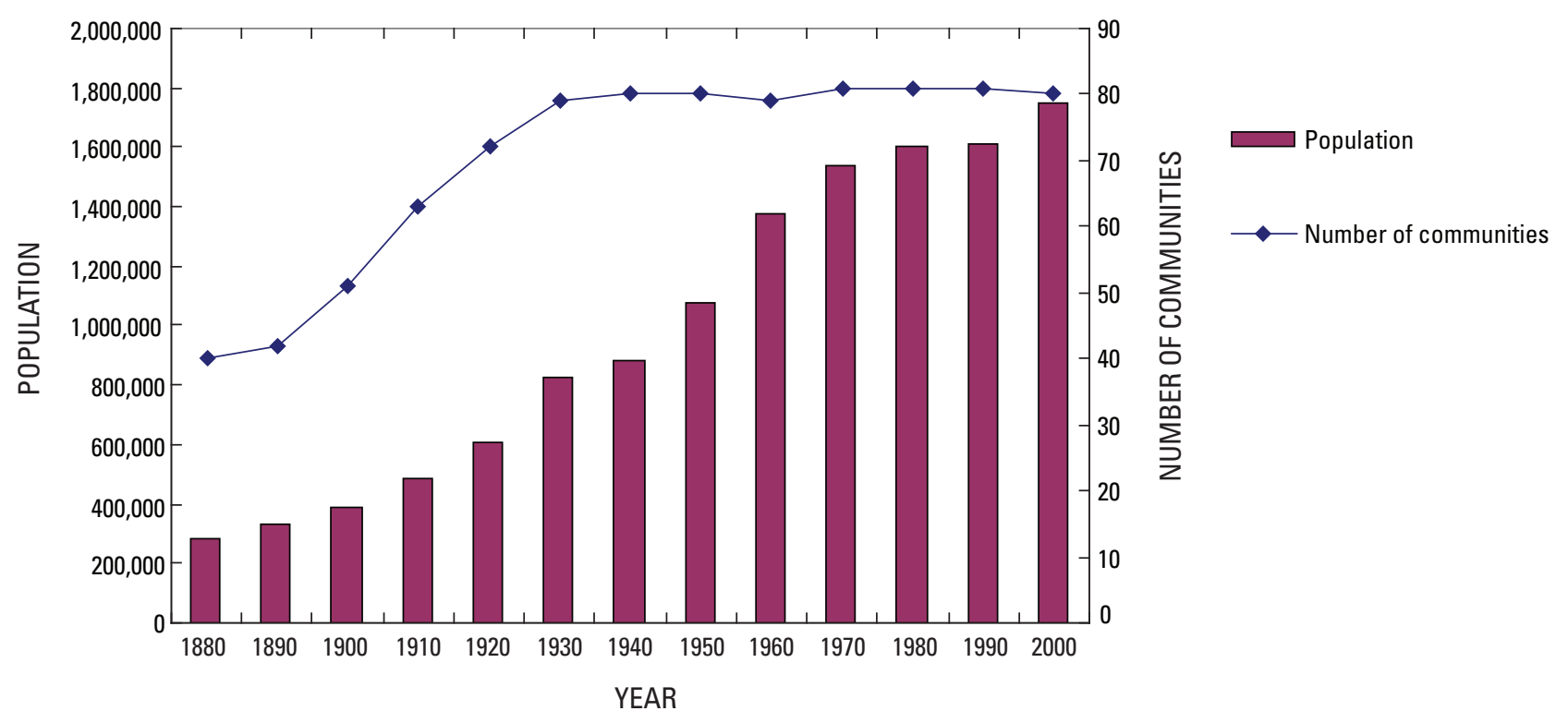

Figure 18. Population and number of communities in Northern Indiana counties in the Lake Michigan Basin area.

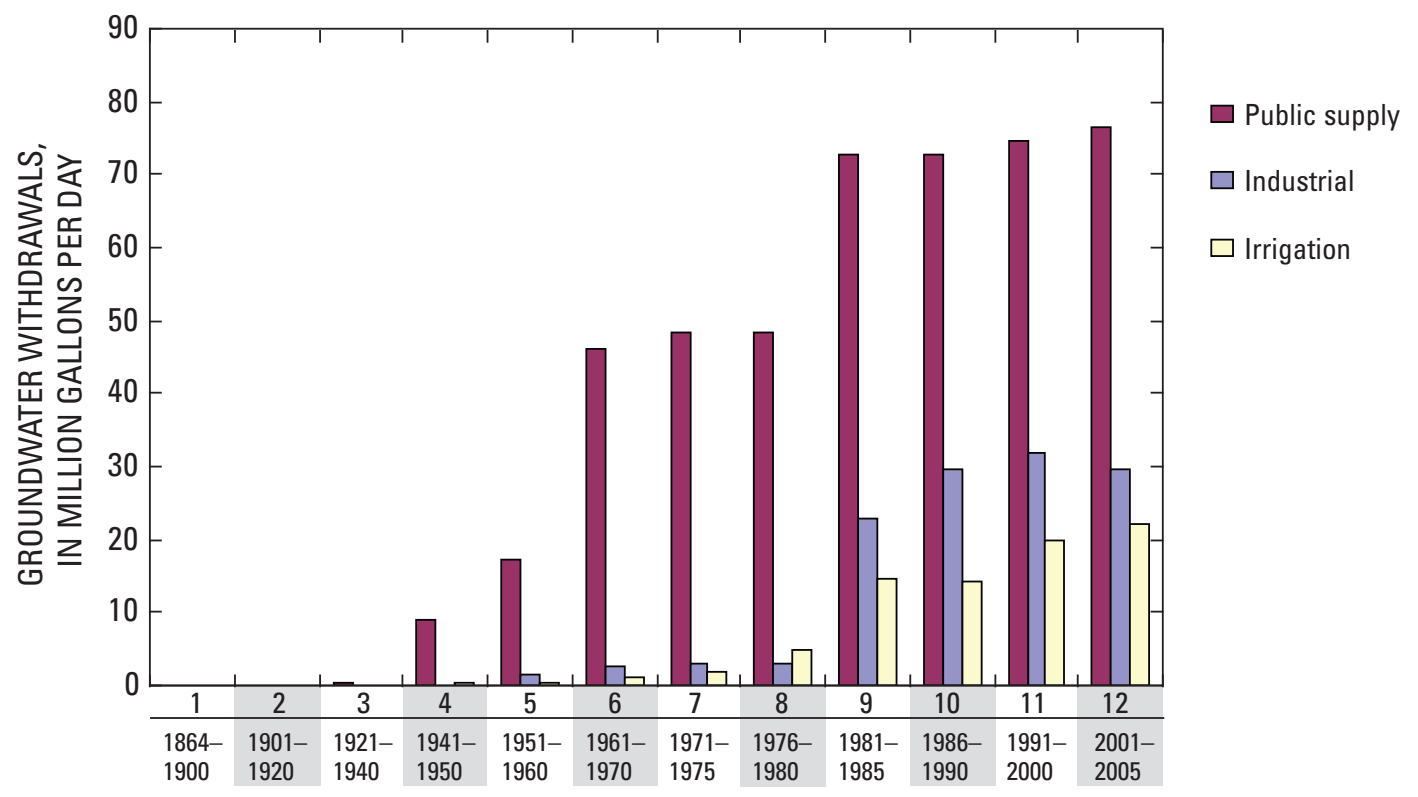

\section{TIME INTERVAL AND YEARS}

Figure 19. Indiana groundwater-use estimates for the Lake Michigan Basin model by time interval and category. No estimates were determined for public-supply use for time intervals 1 to 2 and for industrial and irrigation uses for time intervals 1 to 3 . Groundwater use prior to time interval 9 is estimated and likely does not represent historical trends. Values reflect only a partial estimate of water use in Indiana. 


\section{Public-Supply Water Use in Indiana}

The oldest public water-supply systems determined from available well records and for which withdrawals were estimated in the Indiana LMB model area are for the communities of Cromwell (1920s) and Albion (1920s), Noble County. Because there were 40 communities with reported population data in 1880 , it is likely that other public water-supply systems were operating before the 1920s in this area; however, these data were not available because well-log information was not required to be recorded before the 1950s. Later analysis of historical reports indicated the presence of early public-supply wells in 1880s and 1890s in the communities of Kendalville, Albion, Avilla, and Ligonier, Noble County (Stallman and Klaer, 1950). In St. Joseph County, South Bend's first public water-supply system was established in 1873 and utilized surface water; however, in 1886, use of surface water was abandoned and water wells were installed as the community's water source (Klaer and Stallman, 1948).

Groundwater-use estimates were determined for facilities with wells coded as public supply by the IDNR (table 1). The majority (about 75 percent) of these public-supply wells were for publicly or privately owned water-supply systems, including public water-supply utilities, housing complexes, mobile home parks, and subdivisions. About 24 percent were for facilities such as religious and academic institutions, airports, lodgings, hospitals, and campgrounds that could have been considered commercial in other states' databases. Information was insufficient to distinguish the type of public-supply withdrawal for the remaining 1 percent of the wells.

On the basis of available data, groundwater-use estimates are most reliable for model time intervals 9 to 12 (after 1985); before 1985, all public-supply water use was estimated, and trends are likely not indicative of actual historical withdrawal amounts in the Northern Indiana area (fig. 19, on preceding page). For this category, initial estimates of withdrawals were made for combined time intervals of 1971-80 and 1981-90 instead of separate 5-year time intervals. Later, as these data were incorporated into the groundwater-flow model, wateruse estimates for 1971-80 were assigned to intervals 7 and 8 (1971-75 and 1976-80) and water-use estimates for 1981-90 were assigned to intervals 9 and 10 (1981-85 and 1986-90).

About 21 percent of the groundwater withdrawals in 2004 for public-water supply in Indiana was withdrawn by the 11 counties in Northern Indiana within the Lake Michigan Basin (fig. 10). Estimated withdrawals ranged from $0.21 \mathrm{Mgal} / \mathrm{d}$ for interval $3(1921-40)$ to $76.62 \mathrm{Mgal} / \mathrm{d}$ for interval 12 (2001-5) (table 4) and were primarily from the Northern Indiana model subregion; a few withdrawals were in the farfield model area (fig. 20A, appendix $4 A$ ). For the last four time intervals, public-supply groundwater withdrawals were primarily from the Quaternary aquifer system, with a few withdrawals from the Silurian-Devonian aquifer system (fig. 20B, appen$\operatorname{dix} 4 B$ ). Also for the last four time intervals, public-supply groundwater withdrawals were primarily from unconfined unconsolidated material (fig. 20C, appendix 4C). Because groundwater withdrawals before the last four time intervals were estimated, proportions of withdrawals by aquifer system and aquifer type in appendix $4 C$ are more speculative than data from 1981 on.

Public-supply water use was estimated from data from the SWWF database as well as from per capita use rates and population, as described below. Water-use estimates for each community well in the IDNR database were determined by averaging the available withdrawal data for intervals 11 (1991-2000) and 12 (2001-5). Because the IDNR has collected data every year since 1985 , withdrawals were assumed to be zero in any year with no reported water use for a well. Estimated withdrawals were determined for 1981-90 as the average of the available data from 1985-90 based on the assumption that the well had been in operation since 1981 .

For time intervals before 1981, water-use estimates were derived from per capita use rates and population by use of the same procedure as described for the estimation of publicsupply water use for Michigan. Per capita use tended to vary between the communities and between the time intervals (fig. 21). For those communities showing a downward trend in per capita use, the value for the combined intervals 9 and 10 (1981-90) was used; for the remaining communities, an average per capita use was determined for each community to represent the time intervals before 1981. Average per capita use for time intervals before 1981 ranges from 34 to $239 \mathrm{gal} / \mathrm{d}$ per person and averages $120 \mathrm{gal} / \mathrm{d}$ per person. This per capita use rate was multiplied by the average population for each time-interval midpoint to determine estimated public-supply water use; this value was divided equally between all possible wells assigned to each community. A withdrawal amount was estimated for each year with a reported population value.

The initial start date for pumping in each community was determined by the well-construction date, if available. Well-construction dates also were used for public water-supply facilities such as schools and mobile home parks for which there were no reported population data. Water-use estimates were specified for each time interval, beginning with the interval when the well was installed, by using the trend observed for the more recent intervals with reported data.

The reported aquifer information, along with the reported well depth from the SWWF, was used to determine the aquifer system and hydrogeological model unit for each withdrawal. 


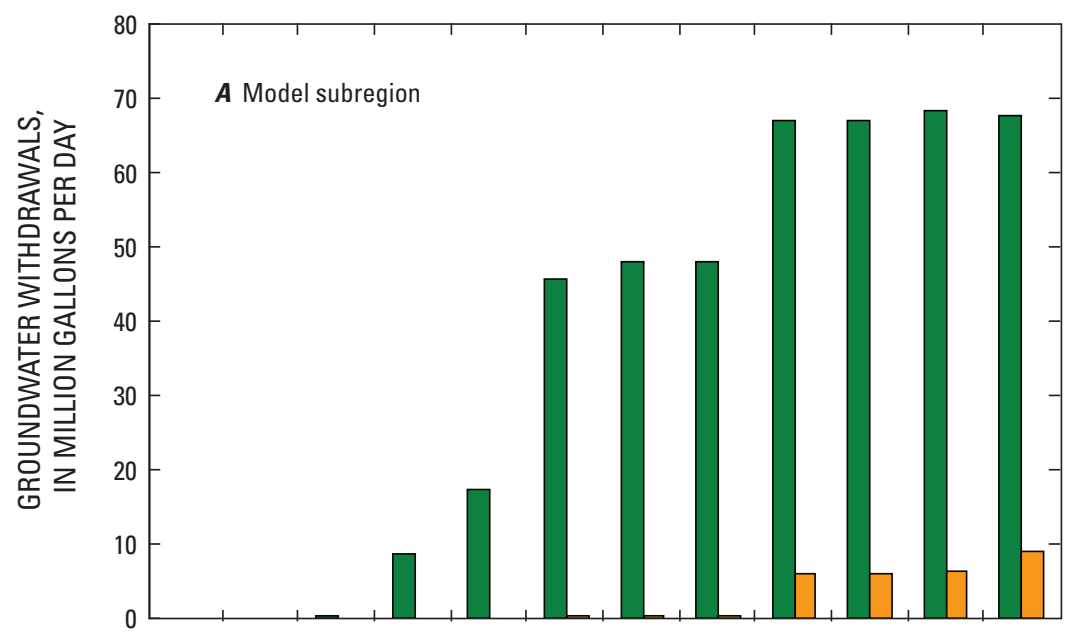
$\square$ Northern Indiana
$\square$ Indiana farfield model area

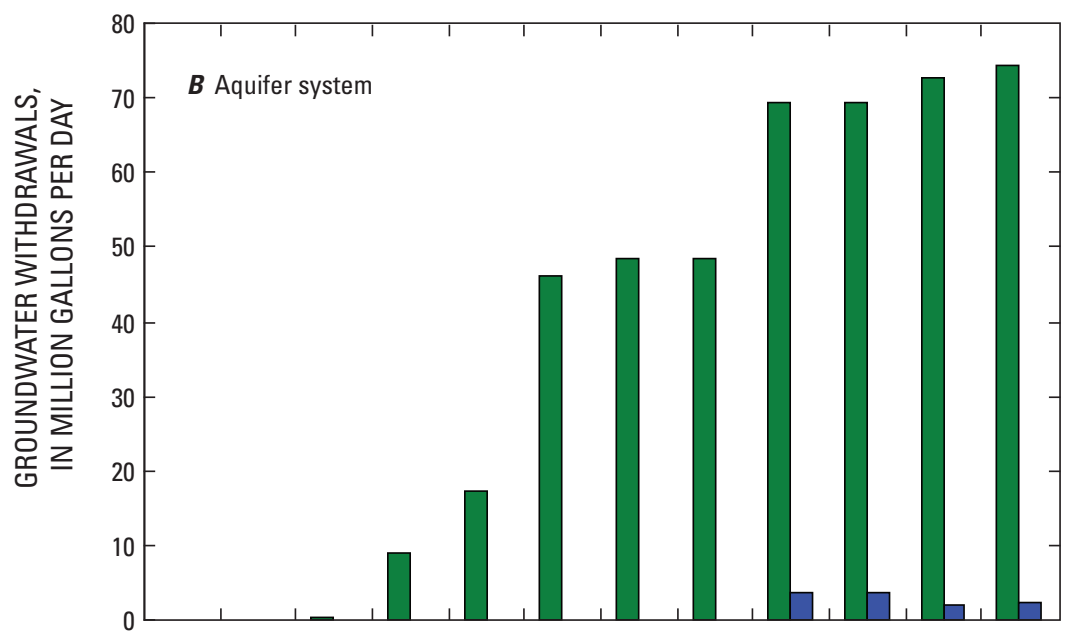

$\square$ Quaternary

$\square$ Silurian-Devonian

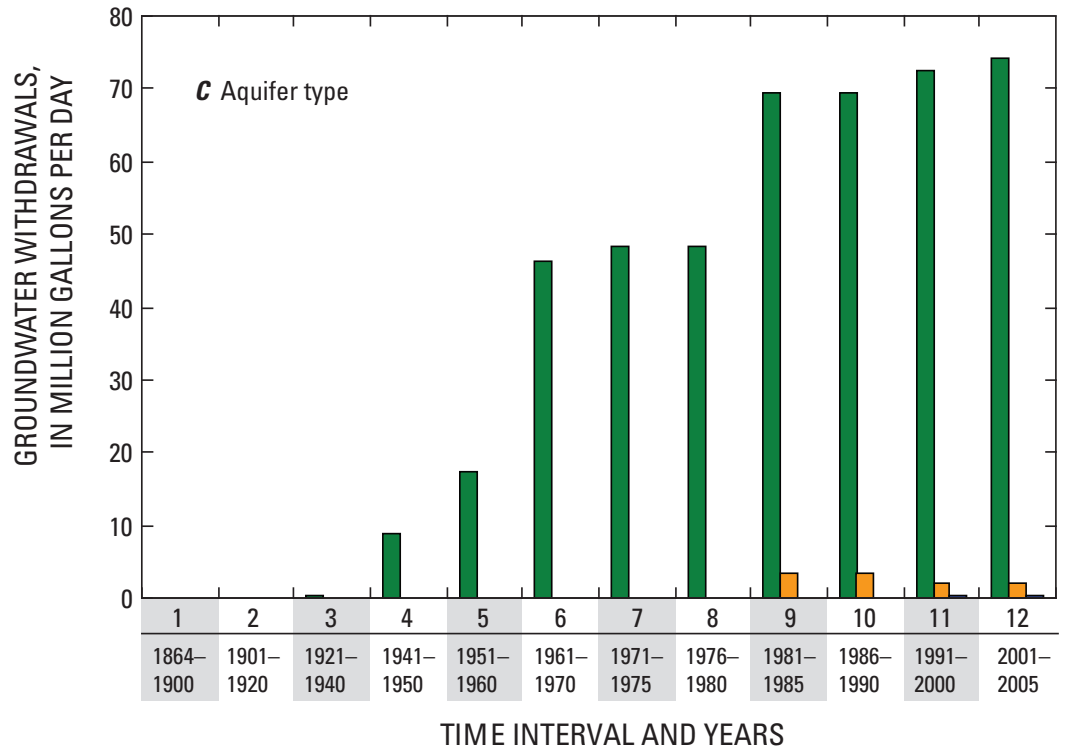

$\square$ Shallow unconsolidated material

$\square$ Shallow bedrock

- Deep bedrock

Figure 20. Public-supply groundwater-use estimates in Indiana for the Lake Michigan Basin model by time interval and $A$, model subregion, $B$, aquifer system, and $C$, aquifer type. Groundwater use prior to time interval 9 is estimated and likely does not represent historical trends. No groundwater-use estimates were determined for the Jurassic-Mississippian, Cambrian-Ordivician, or mixed aquifer systems. Values reflect only a partial estimate of water use in Indiana. 


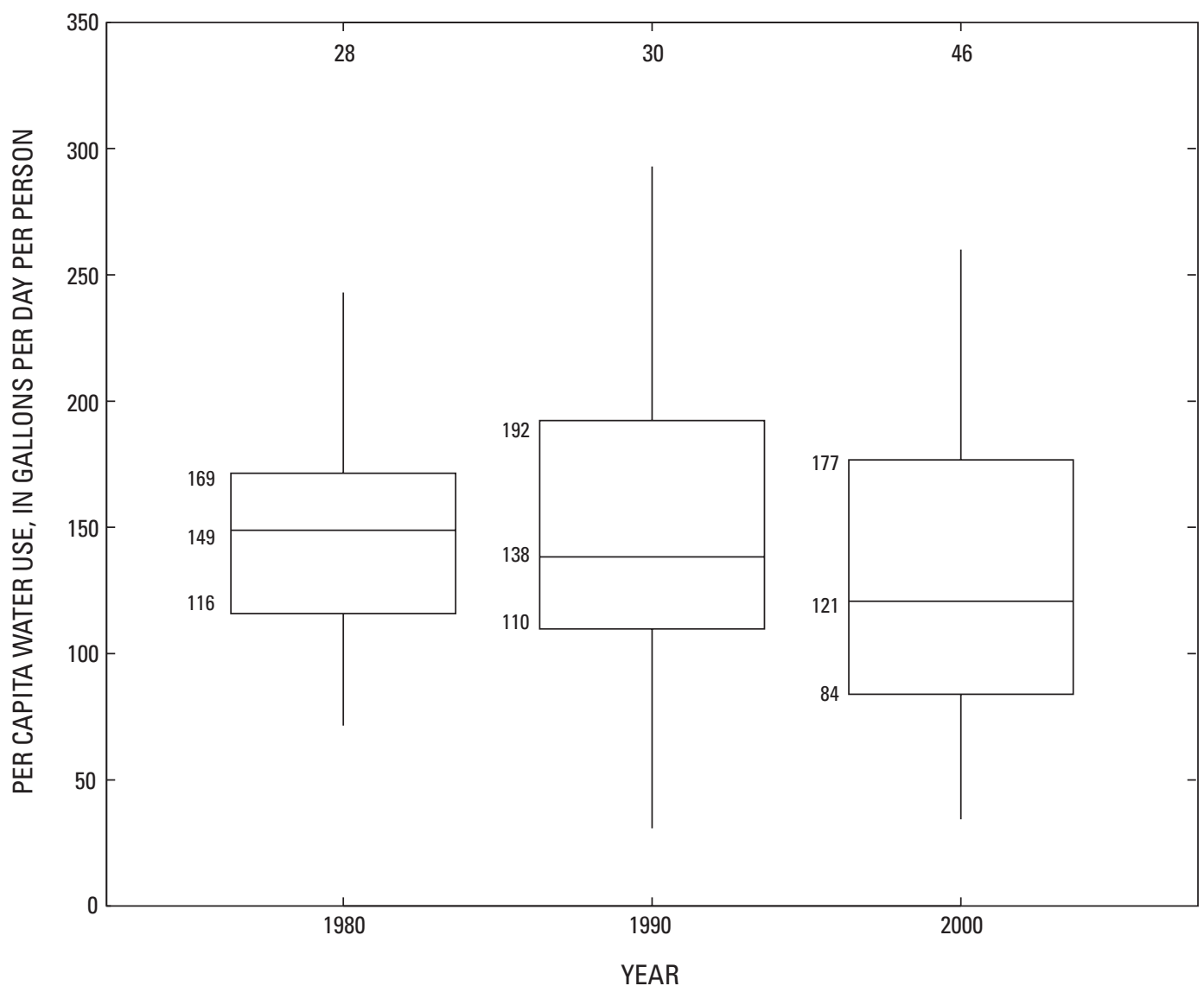

\section{EXPLANATION}

46 Total number of values

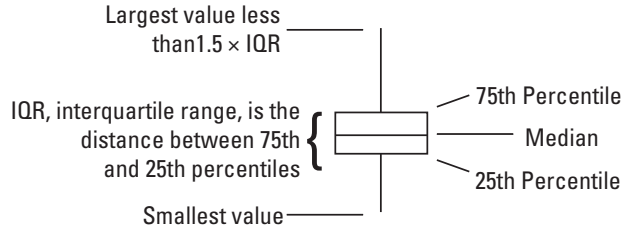

Figure 21. Public-supply per capita water use in the nearfield model area of Indiana, 1980-2000.

\section{Industrial Water Use in Indiana}

Abundant freshwater from Lake Michigan has promoted the development of industries along the southern coast of the lake, especially in Lake and Porter Counties (Indiana Department of Natural Resources, 1994). In 1977, approximately 93 percent of industries were self-supplied, whereas the remaining industries were served by public supplies. The primarymetals industries along the Lake Michigan shoreline in Lake and Porter Counties constitute more than 77 percent of all industrial self-supplied groundwater and surface-water withdrawals in Indiana (Indiana Department of Natural Resources,
2008). In 1990, the industries that were the largest water users in northwestern Lake County included steel manufacturing plants, oil companies, and consumer-product and buildingmaterial manufacturers. In the Lake Michigan Basin, Maumee River Basin, and Kankakee River Basin Regions of Indiana, the majority of water for industry is from surface-water sources (Indiana Department of Natural Resources, 1990, 1994, 1996). In the St. Joseph River Basin, about 63 percent of withdrawals were from groundwater in 1985, with the largest groundwater withdrawals in Elkhart and St. Joseph Counties by machinery, fabricated-metals, and transportation-equipment industries (Indiana Department of Natural Resources, 1987). 
About 19 percent of the groundwater withdrawn in 2004 for industrial uses in Indiana was pumped by the 11 counties within the Indiana LMB area. For model summaries of withdrawals from the various aquifer systems and types, "other water use" (coded as "miscellaneous" in the Indiana database) and energy-production water uses were combined with industrial water use (table 1). Most withdrawals were from the Northern Indiana model subregion, with very few withdrawals from the farfield model area (fig. $22 A$, appendix $4 A$ ). Industrial groundwater withdrawals were primarily from the Quaternary aquifer system, with a few withdrawals from the SilurianDevonian aquifer system; no withdrawals were from the Jurassic-Mississippian or Cambrian-Ordovician systems for the last four time intervals (fig. 22B, appendix $4 B$ ). For the last four intervals, industrial groundwater withdrawals also were primarily from the unconsolidated material aquifer type (fig. $22 C$, appendix 4C). Groundwater withdrawals before 1980 were estimated and likely do not represent the actual proportions of use by aquifer system and type.

The original data from the SWWF database supplied by IDNR (Ralph Spaeth, written commun, 2005) included information for 546 industrial wells, 213 energy-production wells, and 429 other (miscellaneous) wells. However, there were multiple entries for some locations because of changes in registration dates; therefore, the final number of industrial wells was reduced to 296, energy-production wells was reduced to 118 , and other wells was reduced to 256 . Estimated withdrawals range from 0.13 for interval 4 (1941-50) to $29.59 \mathrm{Mgal} / \mathrm{d}$ for interval 12 (2001-5) (table 4). No withdrawals were estimated for the first three time intervals because of a lack of data. Estimated withdrawals are significantly lower before 1985 , but this difference is an artifact of the estimation method and lack of data and likely not indicative of actual withdrawal trends (fig. 18).

Water-use estimates for each industrial well in the IDNR database were determined by averaging the available withdrawal data for intervals 11 (1991-2000) and 12 (2001-5). Because the IDNR has collected data every year since 1985 , withdrawals were assumed to be zero in any year with no reported water use for a well. However, for those facilities with no reported withdrawals in the last interval (2001-5), withdrawals from interval 11 (1991-2000) were substituted as the data were incorporated into the LMB model. Estimated withdrawals were determined for 1981-1990 as the average of the available data from 1985-1990 on the assumption that the well had been in operation since 1981. For time intervals before 1981, water-use estimates were determined by using the trend in reported withdrawals, and well-construction information from the Online Water Well Database was used to determine the date that pumping began.

\section{Irrigation Water Use in Indiana}

The number of irrigated acres in Indiana more than doubled between 1967 and 1977 and doubled again from 1978 to 1987 (Indiana Department of Natural Resources, 1990). Agricultural irrigation is most intensive in the northwest and north-central region of Indiana. In counties that are part of the Lake Michigan Basin and in the Kankakee River Basin, average annual increases in irrigated land have been the greatest in La Porte and St. Joseph Counties. In the Kankakee River Basin, irrigation withdrawals are from both groundwater and surface-water sources and are used primarily for agricultural purposes (Indiana Department of Natural Resources, 1990). In the Lake Michigan Region, most withdrawals are from surfacewater sources and are used primarily for golf course irrigation (Indiana Department of Natural Resources, 1994). In the St. Joseph River Basin, the largest irrigation withdrawals have been in Elkhart, LaGrange, and Kosciusko Counties and from both groundwater and surface-water sources (Indiana Department of Natural Resources, 1987). In the Maumee River Basin, most withdrawals are used primarily for golf course irrigation (Indiana Department of Natural Resources, 1996).

About 50 percent of the groundwater withdrawn for irrigation in 2004 in Indiana was among the 11 counties within the Indiana LMB area. For model summaries of usage by the various aquifer systems and types, rural water use was included in the irrigation report-specific water-use category (table 1). Most withdrawals were from the Northern Indiana model subregion, and very few withdrawals were from the farfield model area (fig. 23A, appendix 4A). Irrigation groundwater withdrawals were primarily from the Quaternary aquifer system, with very small amounts from the Silurian-Devonian aquifer system (fig. 23B, appendix 4B). For the last four time intervals, irrigation groundwater withdrawals also were primarily from the unconsolidated material aquifer type (fig. $23 C$, appendix 4C). Groundwater withdrawals before 1980 were estimated and may not represent the actual proportions of use by aquifer system and type.

The original data from the SWWF database supplied by IDNR (Ralph Spaeth, written commun, 2005) included information for 915 irrigation wells and 17 rural-use wells. However, there were multiple entries for some locations because of changes in registration dates; therefore, the final number of irrigation wells was reduced to 566, and the number of ruraluse wells was reduced to 13. Estimated withdrawals range from $0.26 \mathrm{Mgal} / \mathrm{d}$ for interval 4 (1941-50) to $22.10 \mathrm{Mgal} / \mathrm{d}$ for interval 12 (2001-5) (table 4). No withdrawals were estimated for the first three intervals. Estimated withdrawals are substantially smaller before interval 9 (1981-85), but this difference is an artifact of the estimation method and lack of data and might not be indicative of actual withdrawal trends (fig. 18). Wateruse estimates for irrigation in Indiana were determined by the same procedures outlined for the Indiana industrial water-use estimates. 


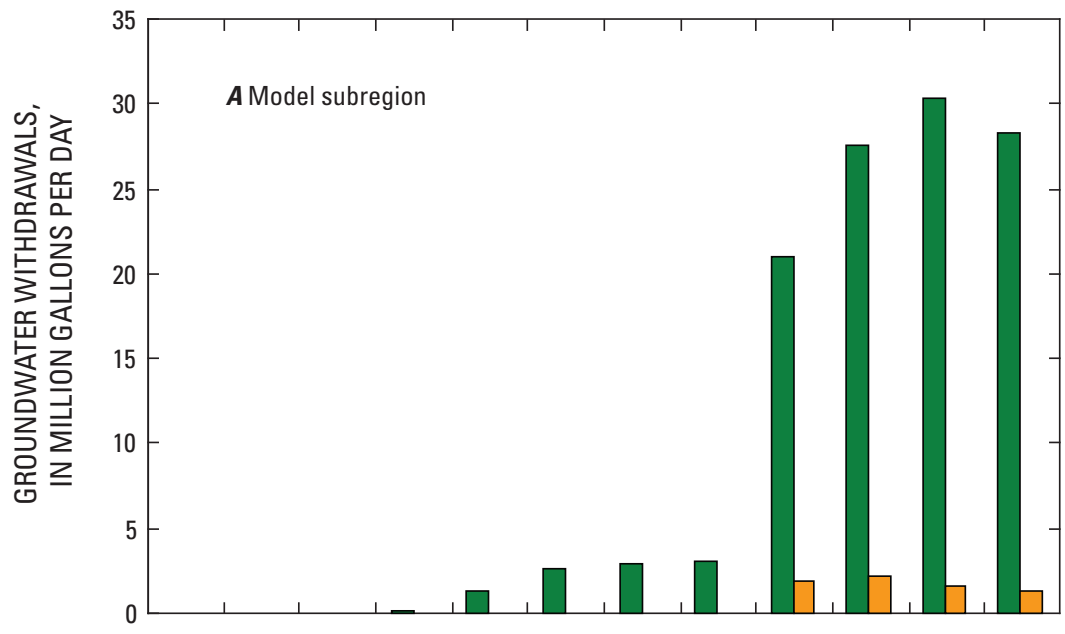

$\square$ Northern Indiana

$\square$ Indiana farfield model area

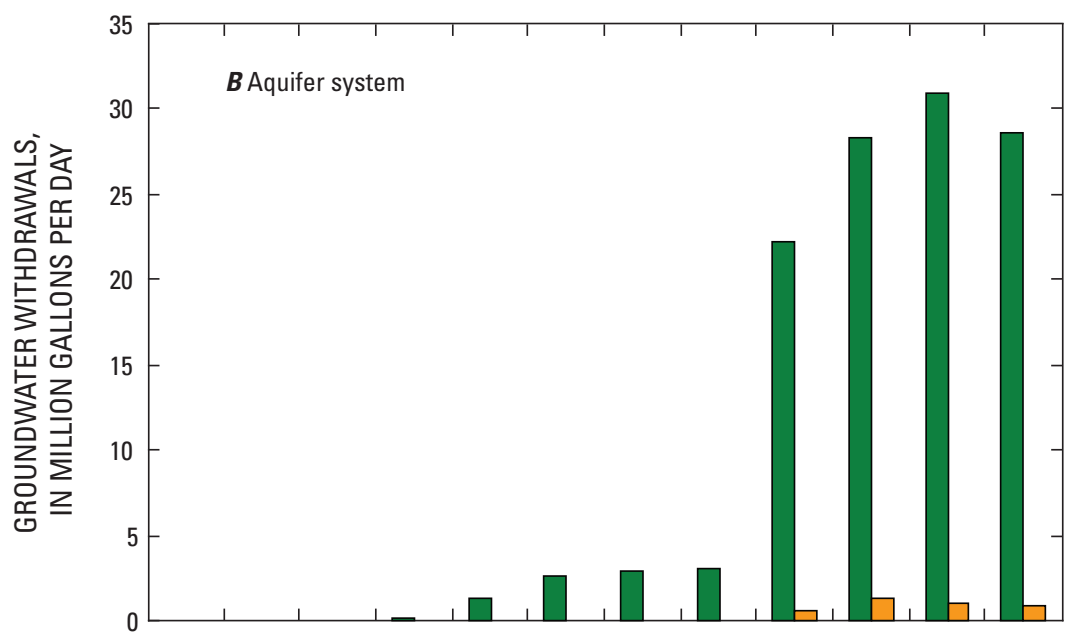

$\square$ Quaternary

$\square$ Silurian-Devonian

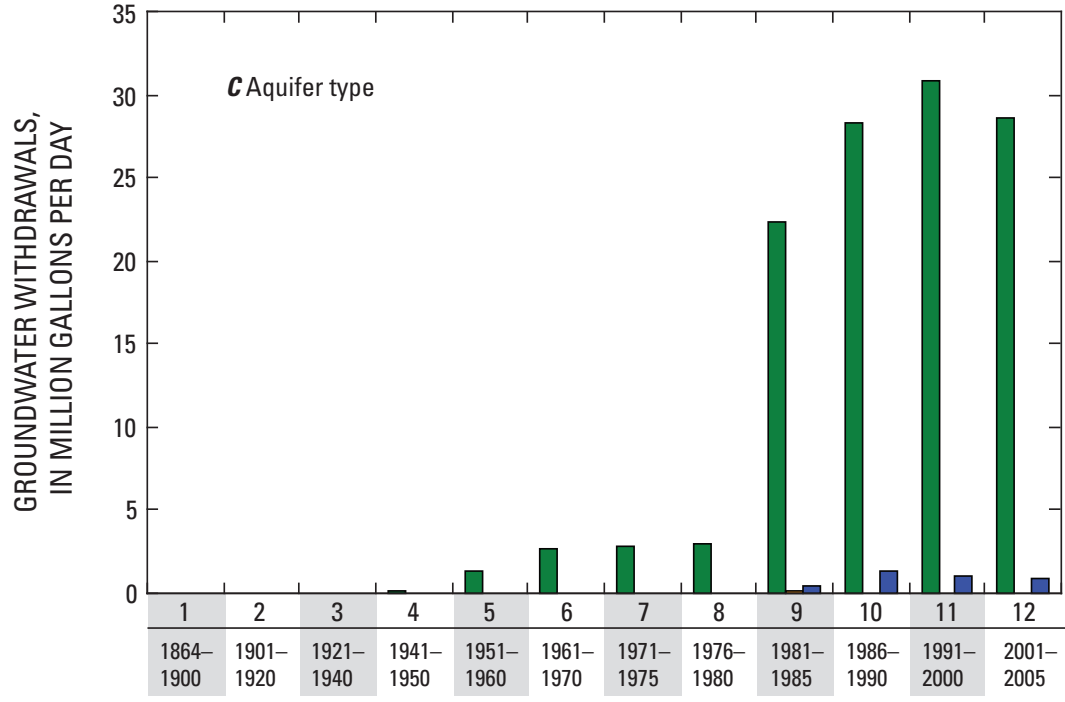

- Shallow unconsolidated materia

$\square$ Shallow bedrock

$\square$ Deep bedrock

TIME INTERVAL AND YEARS

Figure 22. Industrial groundwater-use estimates in Indiana for the Lake Michigan Basin model by time interval and $A$, model subregion, $B$, aquifer system, and $C$, aquifer type. Groundwater use prior to time interval 9 is estimated and likely does not represent historical trends. No groundwater-use estimates were determined for the Jurassic-Mississippian, Cambrian-Ordivician, or mixed aquifer systems. Values reflect only a partial estimate of water use in Indiana. 

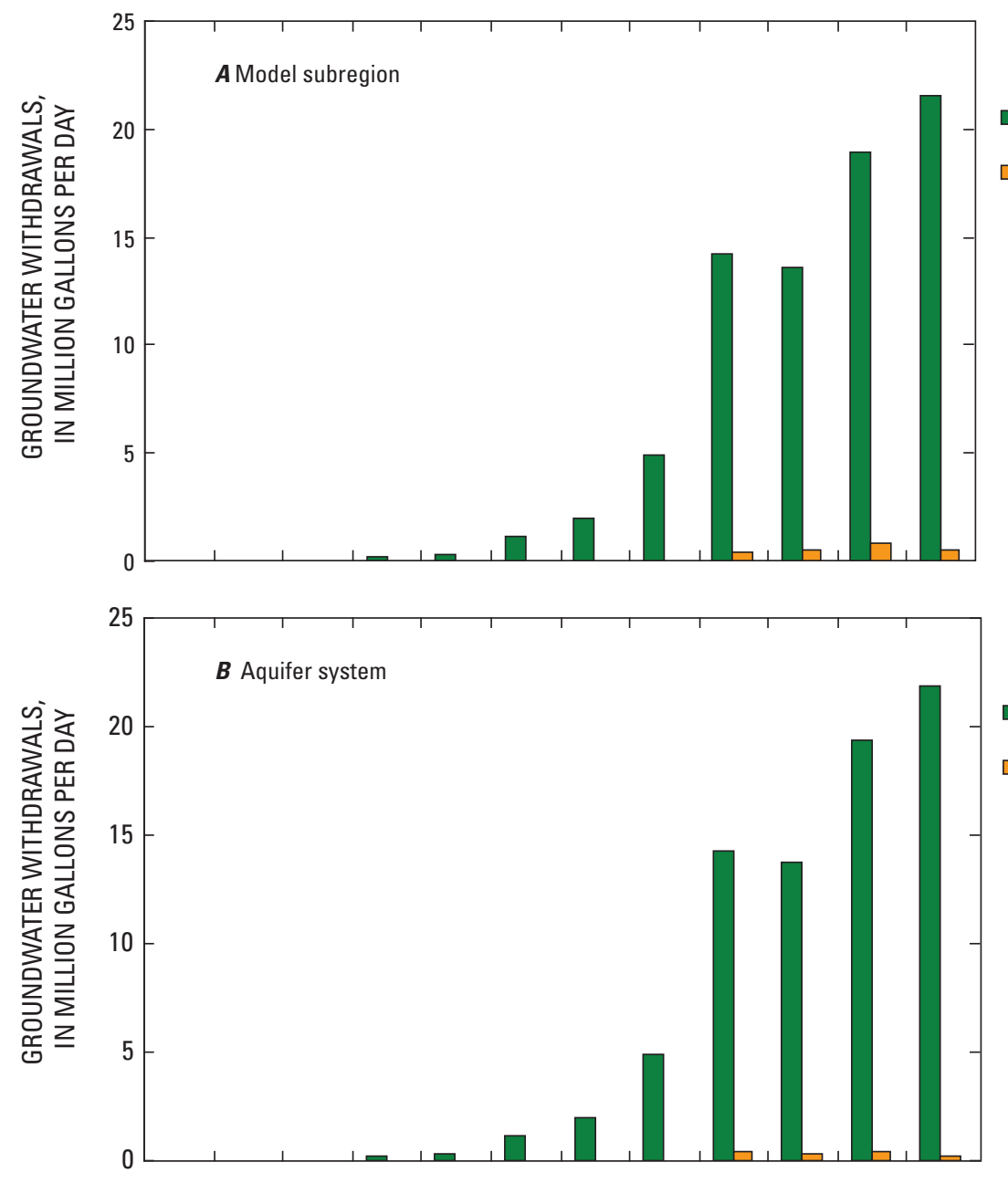

Northern Indiana

$\square$ Indiana farfield model area

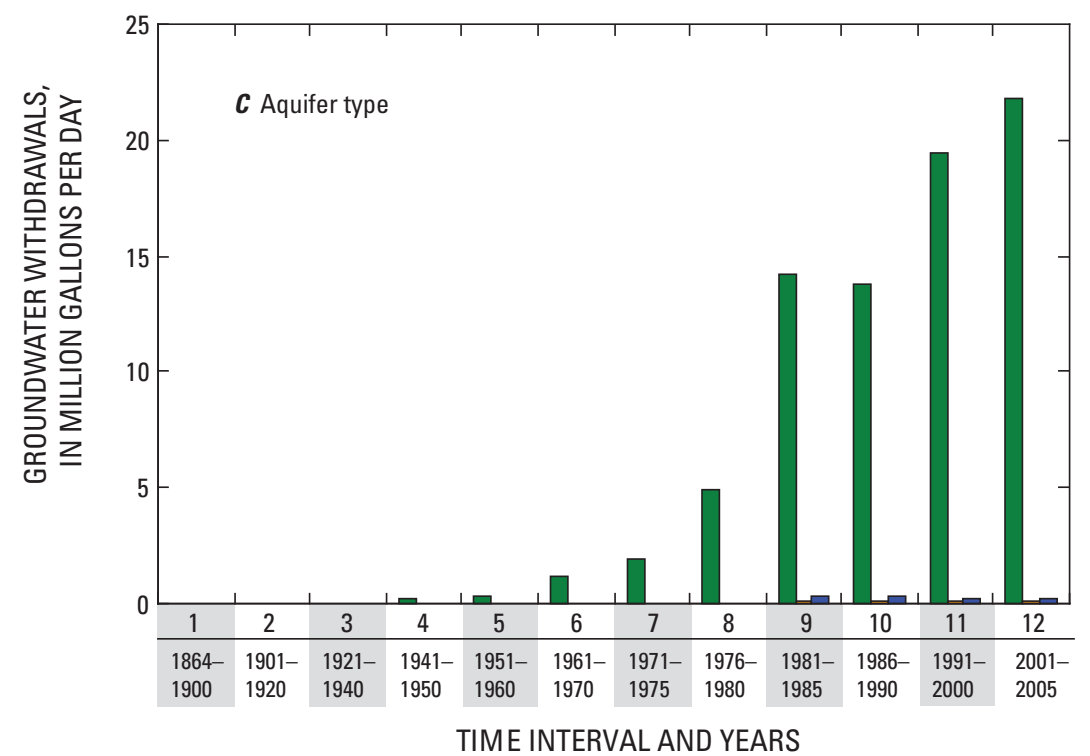

- Shallow unconsolidated material

$\square$ Shallow bedrock

- Deep bedrock

Figure 23. Irrigation groundwater-use estimates in Indiana for the Lake Michigan Basin model by time interval and $A$, model subregion, $B$, aquifer system, and $C$, aquifer type. Groundwater use prior to time interval 9 is estimated and likely does not represent historical trends. No groundwater-use estimates were determined for the Jurassic-Mississippian, Cambrian-Ordivician, or mixed aquifer systems. Values reflect only a partial estimate of water use in Indiana. 


\section{Assumptions and Limitations of Indiana Public- Supply, Industrial, and Irrigation Data}

The groundwater withdrawals compiled and estimated for this study include the assumption that estimates furnished by each facility are accurate, reliable, and consistent from year to year. Estimates for time intervals before interval 9 (1981-85) are based on the assumption that the location of withdrawals and sources did not change before 1985. Some withdrawal information for industrial use was available from historical reports; however, insufficient information was available to determine withdrawal locations, well depths, and duration of pumping. The estimates prepared for this study likely exclude water use by facilities that withdrew water and then ceased operations or changed to a surface-water or a purchased source before 1985. Only those facilities that meet the reportingcapacity threshold are included; therefore, these water-use estimates likely underestimate actual groundwater usage. Any withdrawals from counties other than those listed above were not included in this compilation, although the impact of these is expected to be small and to have little effect on water levels in the nearfield model area or primary area of interest in the basin. However, these omissions could affect inset-model results if any local models are placed in this area.

The population estimates compiled from U.S. Bureau of the Census reports also are assumed to be accurate and collected in a consistent manner each census year. Water-use estimates determined by using population data are based on the assumption that population figures were recorded accurately and published by the census at the same time the water-supply system began supplying customers and, likewise, that withdrawals were initiated when a well was installed. Public-supply withdrawals may be underestimated for those water-supply systems with no early well records. The water-use estimates determined from per capita use are based on the assumption that all people residing within the community were supplied by the public water-supply system and that no areas outside of community were supplied by that same water-supply system. Thus, these estimates could be excluding water that is withdrawn by one water-supply system and sold to another area, and they could be overestimating withdrawals if only part of the community is served by the water supplier. Water-use estimates determined from per capita use also are based on the assumption that the proportion of residential versus other uses is the same for each time interval for each community. Thus, these estimates could be excluding water distributed for publicly supplied industrial or other uses before 1985 .

\section{Illinois}

\section{History of Groundwater Management and Water- Use Data Collection in Illinois}

Groundwater withdrawals in Illinois, like surface-water withdrawals, are governed under the rule of reasonable use (the resource will not be diminished in quantity, impaired in quality, exploited wastefully, or used maliciously), in accordance with the Illinois Water Use Act of 1983 (WUA) (Illinois General Assembly, 1984). Before the WUA, wateruse disputes and issues were handled as a matter of case law; for example, referencing the doctrine of absolute ownership of water, by which it was a landowner's right to withdraw groundwater if that use does not unreasonably interfere with a neighbor's use (Clark, 1985). Although the Illinois WUA does not require withdrawal permits for groundwater use or reporting of groundwater use, it requires well-drilling permits from the Department of Public Health, USEPA, and Illinois Department of Natural Resources for most wells, including those for households, public supply, irrigation, industrial use, and other uses not involving drinking water (Beck and others, 1996). The Illinois WUA and later amendments require notification from property owners to the local county Soil and Water Conservation District (SWCD) regarding high-capacity wells capable of withdrawing $100,000 \mathrm{gal} / \mathrm{d}$ or more of water from a groundwater source. The SWCD, along with the Illinois State Water Survey (ISWS) and Illinois State Geological Survey, review and disclose effects of the proposed withdrawal, such as potential effects on other neighboring groundwater users. In addition, withdrawals may be restricted from high-capacity wells during emergency intervals within four counties of the Illinois LMB model area: Kankakee, Iroquois, McLean, and Tazewell (fig. 3) (Beck and others, 1996).

To help in the assessment of water availability, documentation of annual water withdrawals throughout Illinois began in 1964 with a water-withdrawal program established by ISWS. This program involved collecting and maintaining paper records of well driller's geological logs and estimated withdrawals for individual wells associated with major water users, which included mostly public-supply and industrial wells. It was not until 1978, under a cooperative agreement between the ISWS and USGS as part of the Northern Midwest Regional Aquifer Systems Analysis (RASA) study area (Young, 1992; Sun and others, 1997), that the earlier withdrawal-tracking program was officially expanded and established as the Illinois Water Inventory Program (IWIP). This program collects annual withdrawal data by voluntary submission of a form (known as the Public Industrial-Commercial-Survey (PICS)) sent to high-capacity water users and populates the electronic database for the collected information. Then in 1985, the State of Illinois also signed the Great Lakes Charter along with the other Great Lakes States and Canadian Provinces to cooperatively manage the waters of the 
Great Lakes (Council of Great Lakes Governors, 1985). After completion of the RASA study, the IWIP continued to collect these data through the Center for Groundwater Science of the ISWS (Scott Meyer, Illinois State Water Survey, unpub. data, 2006). Even though only a small part of Illinois is within the Lake Michigan Basin, groundwater withdrawals in Chicago and other surrounding metropolitan areas have caused regional drawdown (the amount of water-level decline from predevelopment conditions caused by pumping); this drawdown amounts to hundreds of feet and extends into southeastern Wisconsin (Sasman and others, 1961; Burch, 1991; Southeastern Wisconsin Regional Planning Commission and Wisconsin Geological and Natural History Survey, 2002; Feinstein and others, 2004). Much of these withdrawals is from the Cambrian-Ordovician aquifer system. For the LMB model, water-use data for Illinois were not compiled and estimated in the same manner as for Wisconsin and Michigan. Rather, the data were provided as an electronic database file by the ISWS, similar to the way Indiana data were provided by the IDNR. Therefore, specifics about how these water-use data were derived are not discussed in this report, although a summary describing the water-use categories is provided.

\section{Overview of Illinois Data From the Lake Michigan Basin Study}

The Illinois water-use data can be considered in three distinct blocks of time (1864-1964, 1964-1979, and 1979-2004) based on how the data were inventoried. The groundwaterwithdrawal data from before 1964, corresponding to model time intervals 1 through 5 (1864-1960) and part of interval 6 (1961-1970), were limited to the nearfield model area (which is also the Northeastern Illinois subregion). Those withdrawals were summarized for seven major pumping centers:

Aurora, Batavia, Chicago, Des Plaines, Elgin, Elmhurst, and Joliet. The water-use data compiled for those seven pumping centers were estimated originally by Suter and others (1959) and became part of previous groundwater modeling efforts by Prickett and Lonnquist (1971) and Burch (1991); these studies were limited to the deep Cambrian-Ordovician aquifer system (table 5). Grouping the withdrawals by pumping center ceased in 1964 and, as a result, a 21-Mgal/d increase was recorded simply because of increased availability of data. Water-use estimates from 1964 to 2004 were assigned to intervals 6 through 12 (1961-2005). ISWS did not furnish water-use data for 2005 .

A total of 40 counties shown in figure 3 are included in the Illinois LMB model area, of which 11 counties are within the nearfield model area. Total withdrawals by model area for Illinois are listed in table 2. In the nearfield model area, withdrawals ranged from $6.76 \mathrm{Mgal} / \mathrm{d}$ in time interval 1 (1864-1900) to $301.71 \mathrm{Mgal} / \mathrm{d}$ in interval 8 (1976-80), then decreased to $166.93 \mathrm{Mgal} / \mathrm{d}$ in interval 12 (2001-5). This large decrease in total withdrawal is mostly due to facilities abandoning their wells and connecting to a public watersupply system that used surface water as its water resource; however, during later time intervals - especially intervals 9 and 10 (1981-1990) — some industries ceased operation. No withdrawal estimates are available in the farfield model area until interval 6 (1961-70); withdrawals increased from $50.74 \mathrm{Mgal} / \mathrm{d}$ in interval 6 to $114.85 \mathrm{Mgal} / \mathrm{d}$ in interval 11 (1991-2000) and then decreased to $110.78 \mathrm{Mgal} / \mathrm{d}$ in interval 12 (table 2). Wells in the nearfield model area withdrew water primarily from bedrock aquifers, whereas wells in the farfield model area withdrew water primarily from unconsolidated material (tables 6 and 7). Withdrawals by subregion are listed in appendix $5 \mathrm{~A}$ and are the same as the withdrawals by model area (table 3 ) because the boundaries are the same.

Appendix $5 B$ lists total water-use estimates for Illinois by water-use category and aquifer system, and appendix $5 C$ lists estimates by water-use category and aquifer type. The uppermost units of the Cambrian-Ordovician aquifer system (specifically the Ironton-Galesville formation) have been the most heavily used, followed by the Silurian-Devonian aquifer system. Water from the deepest hydrogeologic unit, the Mount Simon Sandstone, is generally too saline for domestic or industrial use for most of the Illinois model area (Illinois State Water Survey and Hittman Associates, 1973); therefore, withdrawals are limited to the uppermost $300 \mathrm{ft}$ (model layer 19) (table 6, appendix 1).

\section{Public-Supply Water Use in Illinois}

The majority of the withdrawals in the Illinois model area were for public supply and, on average since interval 6 (1961-70), represented 79 percent of total water use (table 2). Of the 5,819 total records, 3,421 wells were coded as being in the public-supply category by the ISWS (including the 7 early pumping centers). The majority of these public-supply wells were for publicly and privately owned water-supply systems, including community utilities, housing complexes, mobile home parks, and subdivision wells; however, around 7 percent of the wells were for facilities that could have been considered commercial in this database (as they were for Wisconsin). ${ }^{11}$ These commercial establishments include nursing homes, prisons, asylums, religious and academic institutions, airports, and campgrounds, and they represent between 1 and 2 percent of the total withdrawal from the Illinois LMB area for each time interval.

Public supply for Chicago and several other lakeshore communities was initially from surface-water sources; therefore, most of the public-supply groundwater pumpage for time intervals 1 through $6(1864-1970)$ can be attributed to communities that are more to the interior of the Northeastern Illinois subregion and adjacent to Chicago, such as Joliet and Des Plaines. Public-supply withdrawals peaked in interval 9 (1981-85) at $326.12 \mathrm{Mgal} / \mathrm{d}$ and have since been declining (table 4 , appendix 5). The majority of these withdrawals

\footnotetext{
${ }^{11}$ According to table 3 called "List of Standard Industrial Classification (SIC) codes by water-use category" of the 2000 guidelines for USGS wateruse compilation (Kenny, 2004).
} 
were from deep confined bedrock, particularly the CambrianOrdovician aquifer system (figs. $24 B$ and 24C). Withdrawals from the Cambrian-Ordovician aquifer system after interval 8 (1976-80) listed in table 5 decreased considerably as withdrawals increased from other water sources, such as Lake Michigan, the Fox River, and the Quaternary aquifer system. Public-supply withdrawals from the Silurian-Devonian aquifer system increased from interval 6 to interval 8 (1961-80) but then declined from interval 9 to interval 12 (1981-2005). Only small amounts were withdrawn from the Jurassic-Mississippian and mixed aquifer systems (fig. 24B).

\section{Industrial Water Use in Illinois}

Groundwater withdrawals for industrial use in the Illinois nearfield model area before 1964 were combined with estimates for public-supply water use at the seven pumping centers listed earlier. Withdrawals since interval 6 (1961-70) were on average around 19 percent of total water use (table 2). Of the 5,819 total records, 1,690 wells were coded as being in the industrial category by the ISWS. The records furnished for this study did not specify industrial water-use purposes, nor did most records have an associated well-owner name that could be used to extrapolate a water-use purpose. (Names were withheld in accordance with ISWS rules associated with confidentiality disclosures.) Additionally, because there was no miscellaneous water-use category for the original Illinois data, the few facilities that withdrew groundwater for thermoelectric power generation have been classified under industrial water use. Although this use can be considered minor when compared to total industrial use, their associated withdrawal can be large (Tim Bryant, Illinois State Water Survey, written commun., 2008).

Most industrial water use occurred in Illinois before interval 9 (1981-1985) (fig. 25A); but after peaking during interval $7(1971-75)$ at $71.58 \mathrm{Mgal} / \mathrm{d}$, the total industrial withdrawals - especially those within the Northeastern Illinois subregion - have been declining (appendix $5 A$ ). In effect, total industrial use for the most recent time interval (2001-5) approached about the same rate of withdrawal that occurred in interval 6 (1961-70). The largest industrial groundwater withdrawals for all time intervals were from the CambrianOrdovician aquifer system. Withdrawals ranked second from the Silurian-Devonian aquifer system for intervals 6-8 (1961-80) but then ranked second from the Quaternary aquifer system for intervals 9-12 (1981-2005). Few withdrawals were from the Jurassic-Mississippian and mixed aquifer systems (fig. $25 B$, appendix $5 B$ ). Industrial withdrawals by aquifer type are shown in figure $25 C$, and data are listed in appendix $5 C$.

\section{Irrigation Water Use in Illinois}

Documentation of irrigation withdrawals for agricultural crop production is not comprehensive. The ISWS presumes that there are probably only a few high-capacity irrigation wells within western McHenry and Kankakee Counties (fig. 3) (Scott Meyer, Illinois State Water Survey, unpub. data, 2006). High-capacity wells supplying sod farms, golf courses, and nurseries are included, when known. Withdrawals since interval 6 (1961-70) are on average around 2 percent of total Illinois water use (table 2) for the Illinois LMB model area. Irrigation water-use estimates varied from time interval to time interval. The least amount of irrigation water use was estimated for interval $9(1981-85)$ at $2.80 \mathrm{Mgal} / \mathrm{d}$; however, this dip, which extended to interval 10 (1986-90), was more the result of changing water-use data-collection methods than actual decreased irrigation. The peak in irrigation water use occurred during interval 11 (1991-2000) at 9.44 Mgal/d (table 4).

Most of the groundwater for irrigation in the Illinois LMB area has been withdrawn in the Northeastern Illinois subregion (appendix 5A); but from interval 10 (1986-90) to interval 11 (1991-2000), the irrigation withdrawals in the Illinois farfield model area more than doubled (fig. 26A). Most of these withdrawals were from the Silurian-Devonian aquifer system, but there has been a general increase over time in withdrawals from the Cambrian-Ordovician aquifer system and Quaternary aquifer system (fig. 26B, appendix $5 B$ ). There are no withdrawals from Jurassic-Mississippian and mixed aquifer systems. Irrigation water use had been distributed rather similarly between the shallow unconfined and deep confined bedrock aquifer types, but this proportion shifted over the last two intervals, 11 and 12 (1991-2005), in that withdrawals from unconfined unconsolidated material and deep confined bedrock increased (fig. 26C, appendix 5C). 


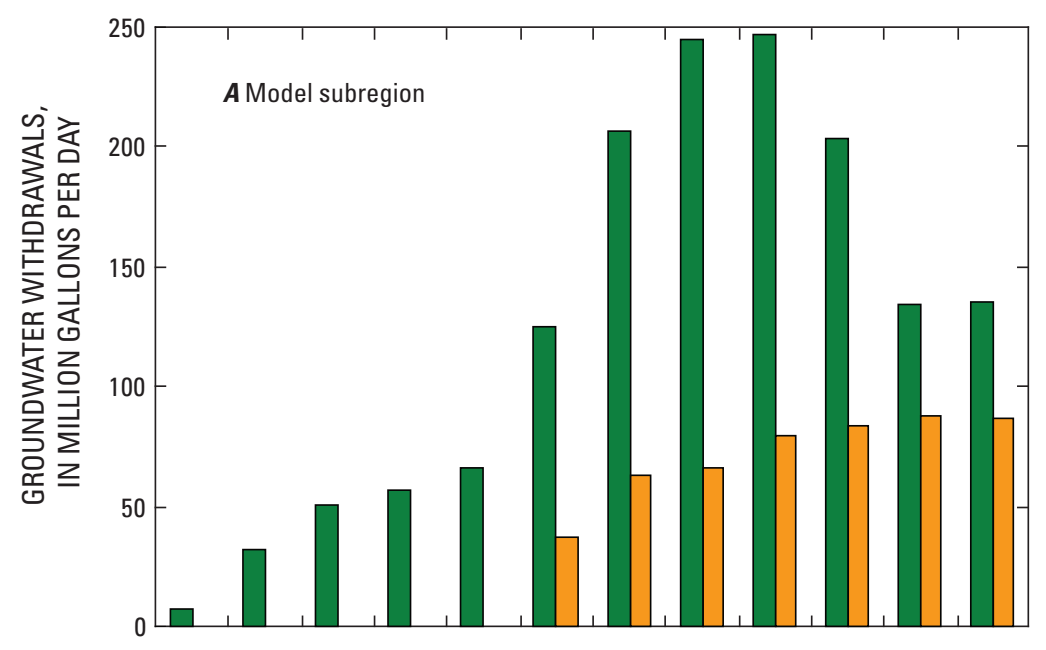

$\square$ Northeastern Illinois

$\square$ Illinois farfield model area

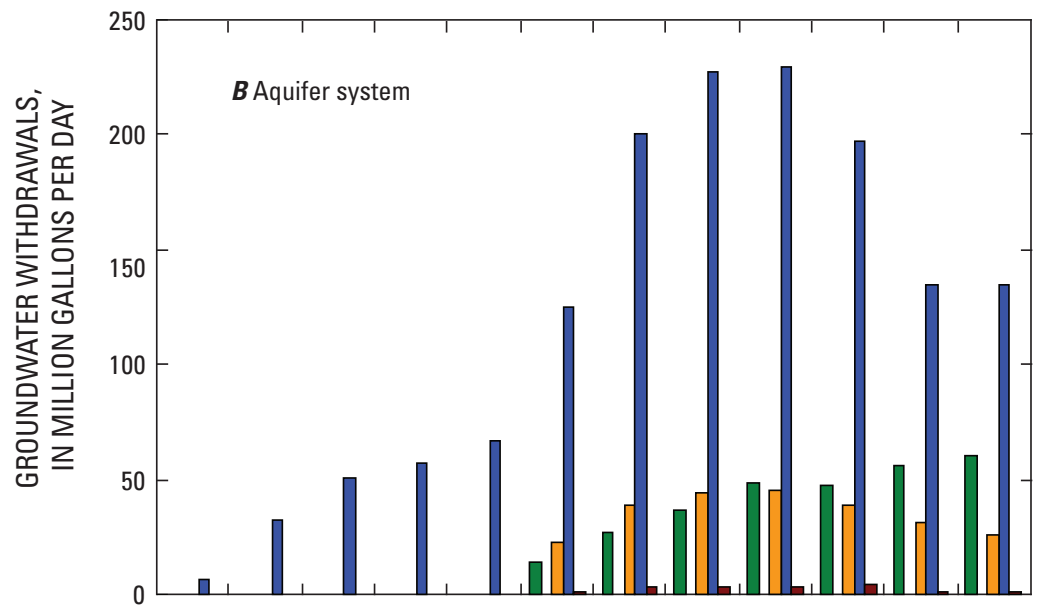

$\square$ Quaternary

$\square$ Jurassic-Mississippian

$\square$ Silurian-Devonian

- Cambrian-Ordovician

$\square$ Mixed

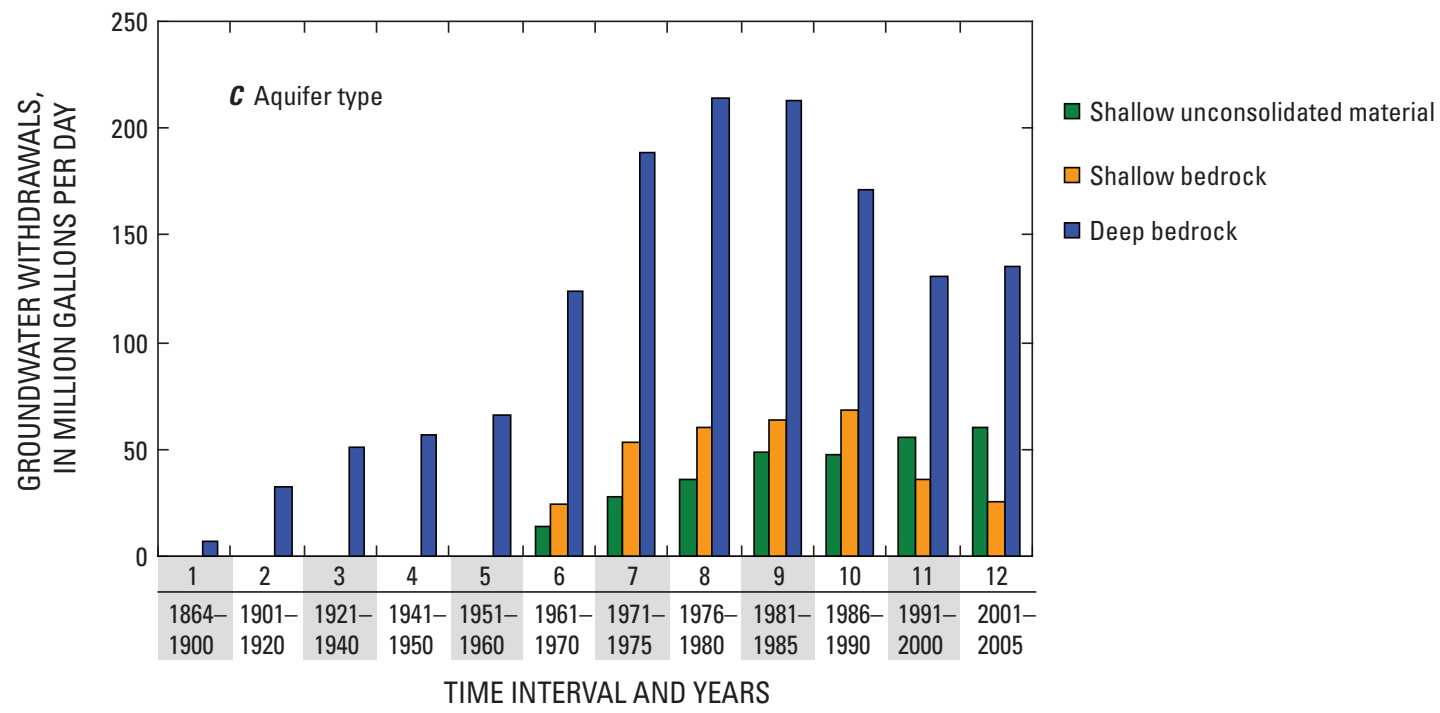

Figure 24. Public-supply groundwater-use estimates in Illinois for the Lake Michigan Basin model by time interval and $A$, model subregion, $B$, aquifer system, and $C$, aquifer type. No farfield model area estimates were determined for time intervals 1 to 5 . 

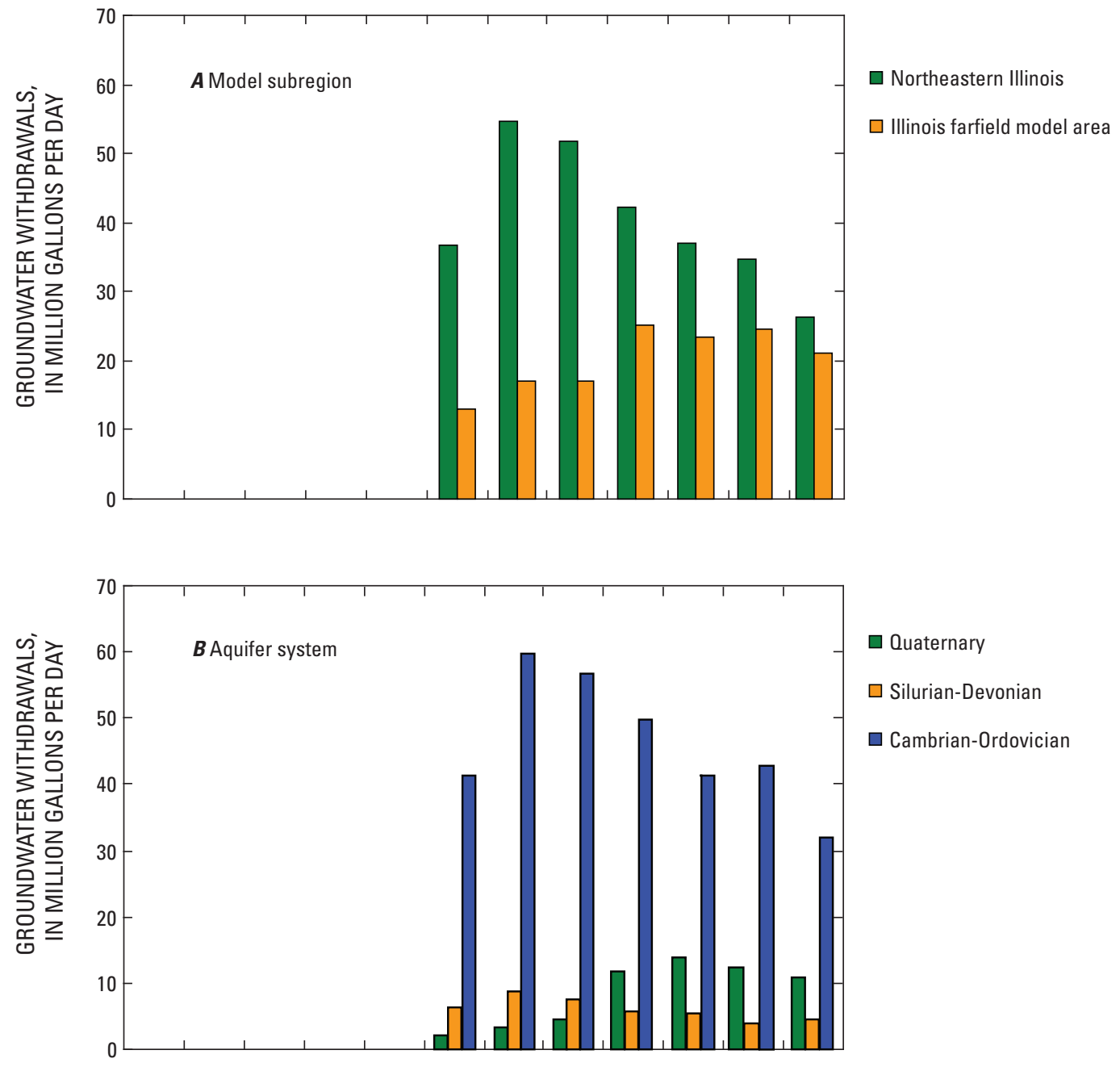

$\square$ Quaternary

$\square$ Silurian-Devonian

- Cambrian-Ordovician

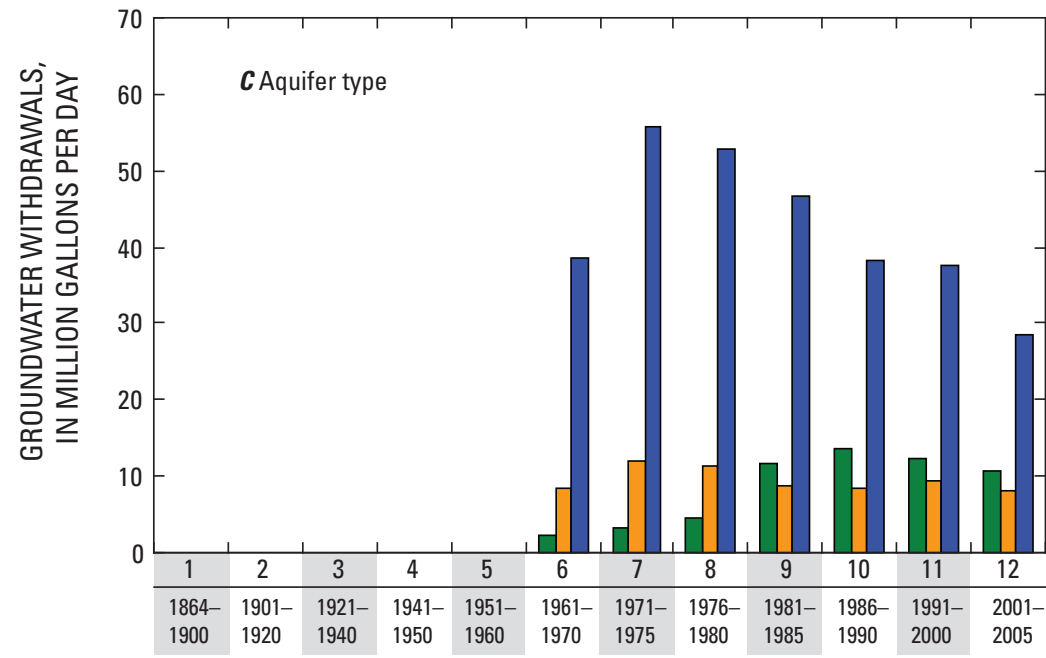

— Shallow unconsolidated material

$\square$ Shallow bedrock

$\square$ Deep bedrock

TIME INTERVAL AND YEARS

Figure 25. Industrial groundwater-use estimates in Illinois for the Lake Michigan Basin model by time interval and $A$, model subregion, $B$, aquifer system, and $C$, aquifer type. No estimates were determined for time intervals 1 to 5 . 

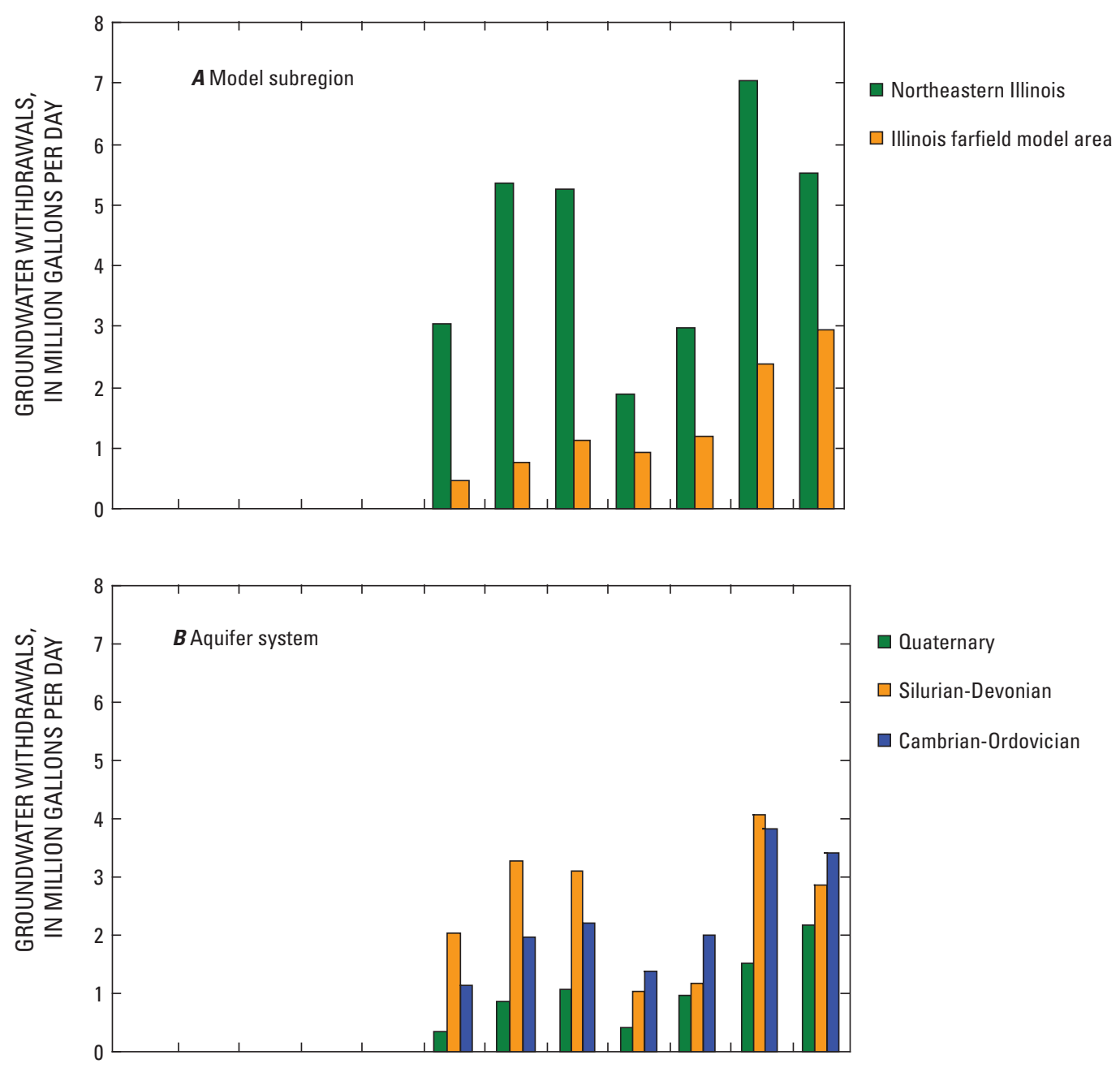

$\square$ Quaternary

$\square$ Silurian-Devonian

- Cambrian-Ordovician

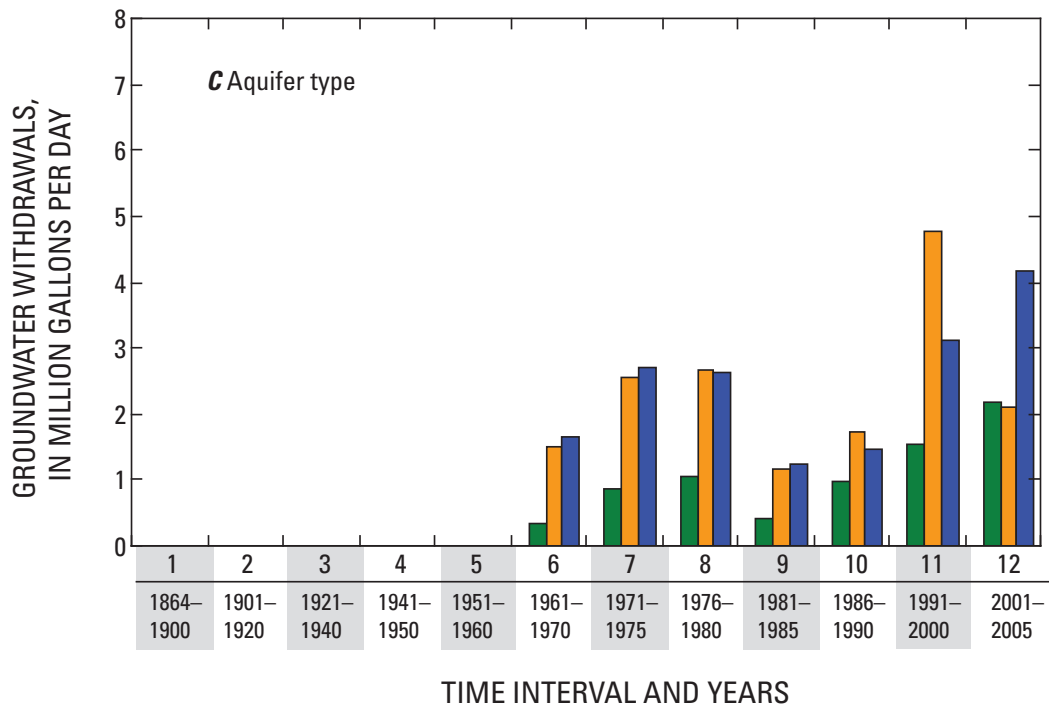

$\square$ Shallow unconsolidated material $\square$ Shallow bedrock

Figure 26. Irrigation groundwater-use estimates in Illinois for the Lake Michigan Basin model by time interval and $A$, model subregion, $B$, aquifer system, and $C$, aquifer type. No estimates were determined for time intervals 1 to 5 . 


\section{Assumptions and Limitations of Illinois Public- Supply, Industrial, and Irrigation Data}

Groundwater-withdrawal data, for various historical reasons, are not well documented in Illinois for the earlier time intervals, especially intervals 1 through 6 (1864-1970); therefore, available data reflect only a partial estimate of water use. The withdrawal data for the seven pumping centers identified earlier represent the best public-supply and industrial groundwater-withdrawal data currently available, although these data were not separated by aquifer system but rather lumped by the ISWS into the Cambrian-Ordovician aquifer system. Withdrawals from the unconsolidated aquifers were not furnished for the years before 1964 but were given for the most recent 40 years (1964-2004). The ISWS explains that this exclusion from the regional model was justified because heads in these shallow aquifers equilibrate quickly to changing withdrawals (Scott Meyer, Illinois State Water Survey, written commun., 2008). For later intervals 7 through 12 (1971-2005), it is assumed by the ISWS that not all wells in the Illinois LMB area are represented, but the public water-supply and industrial wells included are believed to represent the wells from which the majority of total groundwater withdrawals occurred since 1964. The IWIP annual PICS of community and high-capacity industrial users did not begin until 1978, and the data are most complete after 1980 (Scott Meyer, Illinois State Water Survey, unpub. data, 2006). Because data collection was improved by the PICS, many earlier wells identified from paper records were updated as being inactive or abandoned. The survey also was able to capture many facilities that switched from self-supplied groundwater sources to publicly supplied surface water sources, especially during intervals 9 and 10 (1981-90).

For annual water-use data between 1980 and 2004, the ISWS provided withdrawal estimates that reflected wellconstruction and sealing dates, which defined the first and last years that individual wells were active. For wells for which these data were not known, the first year the well was active was assumed to be 1980, and the last year was assumed to be 2004 . However, when these data were further analyzed, it became apparent that withdrawal values were not available for some wells for some years. Several records contained years populated with zero withdrawals, yet it was not possible to determine from the provided dataset which zeros should have been null values and which were for zero pumpage. For Illinois, all water-use data were averaged for each of the 12 defined time intervals, and by including those zero values this method possibly lowered the averaged rate for some intervals.

Some aspects of water-use category definitions vary from state to state. Some facilities that typically would be grouped in the commercial category in other states would be assigned to other categories in Illinois. Because the ISWS database does not contain a commercial water-use category, most of those types of withdrawals would be assigned either to the publicsupply category or the irrigation category. Most were coded as public supply and include taverns, restaurants, nursing homes, prisons, asylums, religious and academic institutions, airports, and campgrounds. Almost all country clubs and municipal parks were coded as irrigation, and the data were stored as irrigation even though some of the water might be used for other purposes. For example, country clubs often use water for the recreational club, pool house, restaurant, lodging, and maintenance shop. Likewise, parks use water for restrooms, showers, nature centers, maintenance and gift shops, and offices. The ISWS database has no miscellaneous water-use category. There was no attempt, as part of this study, to reassign facilities from other categories in to the miscellaneous category as defined for the LMB model. Even if such facilities were reassigned to the miscellaneous category, it is presumed that those withdrawals would be very small and have very little effect on the model.

\section{Summary}

The Great Lakes Basin, which encompasses Lakes Superior, Michigan, Huron, Erie, and Ontario, contains 95 percent of the fresh surface water in North America and 18 percent of the fresh surface water in the world. Groundwater within the Great Lakes Basin constitutes another large volume of freshwater. Yet, even in this water-abundant area, depletion can happen. Sometimes water withdrawals, diversions, and use conflict with the needs of other users and ecosystems in the basin. Thus, at the request of Congress, the U.S. Geological Survey (USGS) is assessing the availability and use of the Nation's water resources to gain a clearer understanding of the status of the resources and the land-use, water-use, and climatic trends that affect them. This national assessment of water availability and use will help characterize how much water is available now, how water availability is changing, and how much water can be expected to be available in the future. The Great Lakes Basin Pilot project of the USGS national assessment of water availability and use focused on the Great Lakes Basin and included detailed studies of the processes governing water availability. One of these studies included the development of a groundwater-flow model of the Lake Michigan Basin.

This report describes the compilation and estimation of the groundwater withdrawals in those areas in Wisconsin, Michigan, Indiana, and Illinois that were needed for the Lake Michigan Basin study groundwater-flow model (LMB model). These data were aggregated for 12 model time intervals spanning 1864 to 2005 and were summarized by model area, model subregion, category of water use, aquifer type, aquifer system, and hydrogeologic unit model layer. Within this period, time was broken down into 12 intervals as follows: (1) 1864-1900, (2) 1901-20, (3) 1921-40, (4) 1941-50, (5) 1951-60, (6) 1961-70, (7) 1971-75, (8) 1976-80, (9) 1981-85, (10) 198690 , (11) 1991-2000, and (12) 2001-5. Water withdrawal for a site or well has been represented by one of four report-specific water-use categories: public supply, industrial, irrigation, and miscellaneous. For most states, additional data represented by 
other water-use categories also were estimated. These reportspecific categories, and the types of data they include, may differ from other USGS or state-specific categories because of differences in how the data were collected, classified, and estimated for each state. For the purposes of this report, wateruse estimates were subdivided into aquifer type on the basis of whether withdrawals were from (1) shallow unconsolidated material, (2) shallow bedrock, and (3) deep bedrock. Wateruse information also was divided into groups corresponding to the following hydrogeologic aquifer systems: (1) Quaternary unconsolidated deposits (model layers 1-3); (2) Jurassic to Mississippian (Marshall Sandstone) bedrock units (model layers 4-8); (3) Silurian-Devonian bedrock units (model layers 9-12); and (4) Cambrian-Ordovician (Sinnipee to Mount Simon) bedrock units (model layers 13-20).

Much of the data included in these datasets can be described more as an assemblage of estimates rather than an assemblage of measured groundwater withdrawals. The types and availability of information on groundwater withdrawals vary considerably among states because water-use programs often differ in the types of data collected and in the methods and frequency of data collection. As a consequence, the methods used to estimate and verify the data also vary. Additionally, because of the different sources of data and different terminologies applied for the purposes of this report, the water-use data published in this report may differ from wateruse data presented in other reports. These data represent only a partial estimate of groundwater use in each state because estimates were compiled only for areas in Wisconsin, Michigan, Indiana, and Illinois within the Lake Michigan Basin model area. Groundwater-withdrawal data were compiled for both nearfield and farfield model areas in Wisconsin and Illinois, whereas these data were compiled primarily for the nearfield model area in Michigan and Indiana.

Overall water use for the selected areas in Wisconsin, Michigan, Indiana, and Illinois was smaller during early time intervals than during more recent intervals, with large increases beginning around the 1960s. These increases in the 1960s are partially explained by the availability of well-log data which were used to determine when pumping began for facilities in the LMB model area. For the most part, early water-use estimates for Michigan and Indiana were based on either minimal reported data or no reported data at all, so the apparent trends for these two states likely are not indicative of actual water use. In some cases for Michigan and Indiana, water withdrawals were not estimated for early time intervals because no information was available.

Total estimated groundwater withdrawals for model input range from 18.01 million gallons per day for interval 1 (1864-1900) to 1,280.25 million gallons per day for interval 12 (2001-5). Withdrawals for the public-supply category make up the majority of the withdrawals in Wisconsin, Michigan, Indiana, and Illinois. In Wisconsin and Michigan, the second largest withdrawals are for the irrigation category; in Indiana and Illinois, industrial withdrawals account for the second largest withdrawal amounts. The smallest withdrawals are for miscellaneous uses in Wisconsin and irrigation uses in Indiana and Illinois. No withdrawals were estimated for miscellaneous uses in Michigan, Indiana, and Illinois.

Estimated groundwater withdrawals in the Southern Lower Peninsula of Michigan, Northeastern Illinois, and the farfield model area are generally larger than in the other model subregions. Withdrawals in Michigan and Indiana are predominantly from the Quaternary aquifer system, whereas withdrawals in Illinois are predominantly from the CambrianOrdovician aquifer systems. Withdrawals in Wisconsin are about equal from the Quaternary and Cambrian-Ordovician aquifer systems. The Jurassic-Mississippian aquifer system also is an important source of water in Michigan but not in the other states. Some wells in Wisconsin and Michigan are completed in the unconsolidated material and underlying bedrock units (classified as a mixed aquifer system), but data from Indiana and Illinois do not specify withdrawals from any wells that are open to both of these different aquifer systems. Estimated groundwater withdrawals in Michigan and Indiana are predominantly from the unconfined unconsolidated aquifer type. Withdrawals in Illinois are largely from the deep confined bedrock aquifer type, although they have decreased considerably in more recent time intervals. Wisconsin withdrawals are about equal from unconfined unconsolidated and deep confined bedrock aquifer types.

Wisconsin groundwater use was estimated by using groundwater information and data from the Wisconsin Department of Natural Resources high-capacity well approval program combined with several other key data sources, such as the wiscLITH well-log and USGS databases, previous groundwater-modeling project archives, U.S. Department of Agriculture (USDA) Census of Agriculture reports, information searches, and correspondence. Groundwater-withdrawal estimates were compiled for the 47 easternmost counties in Wisconsin within the boundary of the LMB model, of which 32 counties, though not entirely contained, are at least partly within the Lake Michigan Basin. Overall, 6,457 withdrawal locations were estimated in the Wisconsin part of the LMB model area, and 5,151 locations were active in the last time interval (2001-5) for a total groundwater withdrawal of 476.51 Mgal/d.

Wisconsin well-log records collected for this study show that most early development was within the nearfield model area south of Green Bay and was within proximity of Lake Winnebago and Lake Michigan. In general, much water is still used in this part of the State, although water-use growth has been considerable in adjacent regions of the farfield model area, especially within and surrounding the Central Sand Plains of Wisconsin (which includes most central Wisconsin counties). Total withdrawals in Wisconsin increased consistently from $1.84 \mathrm{Mgal} / \mathrm{d}$ in time interval 1 (1864-1900) to 192.88 Mgal/d in interval 12 (2001-5) for the nearfield model area and increased from $1.35 \mathrm{Mgal} / \mathrm{d}$ in interval 1 to 283.63 $\mathrm{Mgal} / \mathrm{d}$ in interval 12 for the farfield model area. The Northeastern Wisconsin subregion is quite extensive and covers all or parts of 24 counties, whereas the Southeastern Wisconsin 
subregion comprises all or parts of 9 counties; therefore, total withdrawals in the Northeastern Wisconsin subregion for most time intervals are greater than those for the Southeastern Wisconsin subregion, the exceptions being the first two intervals (1864-1920). The withdrawals in Northeastern Wisconsin increased from $0.82 \mathrm{Mgal} / \mathrm{d}$ in interval 1 to $118.59 \mathrm{Mgal} / \mathrm{d}$ in interval 12. The withdrawals in Southeastern Wisconsin increased from $1.02 \mathrm{Mgal} / \mathrm{d}$ in interval 1 to $76.57 \mathrm{Mgal} / \mathrm{d}$ in interval 12, with the exception of interval 10 (1986-1990).

Michigan groundwater use was estimated by using groundwater information and data from the Michigan Department of Environmental Quality Water Use Reporting Program and Wellogic database, Groundwater Inventory and Mapping Web sites, previous reports, former USGS modeling water-use datasets, information searches, USDA Census of Agriculture reports, an irrigation scheduler model, and correspondence. The Michigan LMB model area consists of those counties in Michigan with at least some part within the boundaries of the basin, plus Monroe County. Monroe County water use was included in the publicsupply and industrial category estimates along with the Lake Michigan Basin counties because of large groundwater withdrawals for industrial use. From Michigan's total of 83 counties, water-use estimates were determined for public-supply use in 56 counties, for industrial use in 47 counties, for agricultural irrigation use in 11 counties, and for golf course irrigation use in 49 counties. Overall, there were 2,046 withdrawal locations estimated for counties within the Michigan LMB model area, and 1,860 locations were active in the last time interval (2001-5) for a total withdrawal of $397.72 \mathrm{Mgal} / \mathrm{d}$.

Michigan well logs collected for this study show that most early development was in the central part of the Lower Peninsula of Michigan, which corresponds to the northern part of the Southern Lower Peninsula subregion and the southern part of the Northern Lower Peninsula subregion used in this report. Estimated withdrawals for the nearfield model area equaled $7.43 \mathrm{Mgal} / \mathrm{d}$ in time interval 1 (1864-1900) and 359.91 Mgal/d in interval 12 (2001-5); farfield model area withdrawals equaled $0.63 \mathrm{Mgal} / \mathrm{d}$ in interval 1 and 37.81 $\mathrm{Mgal} / \mathrm{d}$ in interval 12. When evaluating these estimated withdrawals in Michigan, it is important to remember that wateruse estimates were compiled primarily for counties within the nearfield model area and that these estimates do not represent the total amount of groundwater withdrawn in Michigan for these categories. Farfield estimates compiled for this study were from Monroe County and other counties intersected by the nearfield model boundary. Estimated withdrawals by nearfield model subregions for interval 1 to interval 12 ranged from 7.21 Mgal/d to $306.15 \mathrm{Mgal} / \mathrm{d}$ in the Southern Lower Peninsula, $0.22 \mathrm{Mgal} / \mathrm{d}$ to $44.83 \mathrm{Mgal} / \mathrm{d}$ in the Northern Lower Peninsula, and 0 to $8.94 \mathrm{Mgal} / \mathrm{d}$ in the Upper Peninsula.

Indiana groundwater use was estimated by using groundwater information and data from the Indiana Department of Natural Resources Division of Water's Water Rights and Use Section Significant Water Withdrawal Facility database and the Online Water Well Database, information searches, and previous reports. The Indiana part of the LMB model area consists of 11 counties in the Northern Indiana subregion, all of which have at least some part within the Lake Michigan Basin boundary: Allen, Dekalb, Elkhart, Kosciusko, LaGrange, Lake, La Porte, Noble, Porter, St. Joseph, and Steuben. Water use in the Indiana farfield area consists of only those parts of the above-listed counties that are outside of the nearfield model area. Therefore, Indiana water-use estimates were primarily within the nearfield model area. Overall, a total of 2,002 withdrawal locations were estimated for counties within the Indiana LMB model area, and 1,104 locations were active in the last model time interval (2001-5) for a total withdrawal of $128.3 \mathrm{Mgal} / \mathrm{d}$.

Total withdrawals in Indiana for the nearfield model area ranged from $0.21 \mathrm{Mgal} / \mathrm{d}$ in interval $3(1921-40)$ to 117.42 $\mathrm{Mgal} / \mathrm{d}$ in interval 12 (2001-5), and withdrawals from the farfield model area ranged from $0 \mathrm{Mgal} / \mathrm{d}$ in interval 3 to 10.88 $\mathrm{Mgal} / \mathrm{d}$ for interval 12. No withdrawals were estimated in Indiana for the first two time intervals because of a lack of data. It should be emphasized that water-use estimates were compiled primarily for counties within the LMB nearfield model area and that these estimates do not represent the total amount of groundwater withdrawn in Indiana for these categories.

Illinois groundwater use was estimated by using groundwater information and data from the Illinois State Water Survey, the Illinois Water Inventory Program, previous reports, and correspondence. The Illinois water-use data can be considered in three distinct blocks of time (1864-1964, 1964-1979, and 1979-2004) based on how the data were inventoried. The groundwater-withdrawal data from before 1964, corresponding to model time intervals 1 through 5 (1864-1960) and part of interval 6 (1961-1970), were limited to the nearfield model area (which is also the Northeastern Illinois subregion). Those withdrawals were summarized for seven major pumping centers: Aurora, Batavia, Chicago, Des Plaines, Elgin, Elmhurst, and Joliet, and were limited to the deep CambrianOrdovician aquifer system. Grouping the withdrawals by pumping center ceased in 1964 and, as a result, a 21-Mgal/d increase was recorded simply because of increased availability of data. Water-use estimates from 1964 to 2004 were assigned to intervals 6 through 12 (1961-2005) and were estimated for a total of 40 counties in the Illinois LMB model area, of which 11 counties are within the nearfield model area.

Total withdrawals in Illinois for the nearfield model area ranged from $6.76 \mathrm{Mgal} / \mathrm{d}$ in time interval 1 (1864-1900) to $301.71 \mathrm{Mgal} / \mathrm{d}$ in interval 8 (1976-80), then decreased to 166.93 Mgal/d in interval 12 (2001-5). This large decrease in total withdrawal is mostly due to facilities' abandoning their wells and connecting to a public water-supply system that used surface water as its water resource; however, during later time intervals - especially intervals 9 and 10 (1981-1990) some industries ceased operation. No withdrawal estimates are available in the farfield model area until interval 6 (1961-70); withdrawals increased from $50.74 \mathrm{Mgal} / \mathrm{d}$ in interval 6 to $114.85 \mathrm{Mgal} / \mathrm{d}$ in interval 11 (1991-2000) and then decreased to $110.78 \mathrm{Mgal} / \mathrm{d}$ in interval 12 . 


\section{References}

\section{General References}

Feinstein, D.T., Hunt, R.J., and Reeves, H.W., in press, Regional ground-water-flow model of the Lake Michigan Basin in support of Great Lakes Basin water availability and use studies: U.S. Geological Survey Scientific Investigations Report 2010-5109.

Grannemann, N.G., and Reeves, H.W., 2005, Great Lakes Basin water availability and use-A study of the national assessment of water availability and use program: U.S. Geological Survey Fact Sheet 2005-3113, 4 p.

Lampe, D.C., 2009, Hydrogeologic framework of bedrock units and initial salinity distribution for a simulation of groundwater flow for the Lake Michigan Basin: U.S. Geological Survey Scientific Investigations Report 2009-5060, 49 p.

Reilly, T.E., Dennehy, K.F., Alley, W.M., and Cunningham, W.L., 2008, Ground-water availability in the United States: U.S. Geological Survey Circular 1323, 70 p.

Sheets, R.A., and Simonson, L.A., 2006, Compilation of regional ground-water divides for principal aquifers corresponding to the Great Lakes Basin, United States: U.S. Geological Survey Scientific Investigations Report 20065102, 23 p.

Solley, W.B., Pierce, R.R., and Perlman, H.A., 1998, Estimated use of water in the United States in 1995: U.S. Geological Survey Circular 1200, 71 p.

\section{Wisconsin References}

Buchwald, C.A., 2009, Water use in Wisconsin: U.S. Geological Survey Open-File Report 2009-1076, 74 p., accessed October 16, 2009, at http://pubs.usgs.gov/of/2009/1076/.

Central Brown County Water Authority, 2007, Who we are, accessed May 23, 2008, at http://www.cbcwaterauthority. $\mathrm{com} /$.

Cherkauer, D.S., and Carlson, D.A., 2002, Development and calibration of Fond du Lac model, central Wisconsin-Final report to the Wisconsin Department of Natural Resources Source Water Protection Program: 63 p.

Conlon, T.D., 1998, Hydrogeology and simulation of groundwater flow in the sandstone aquifer, northeastern Wisconsin: U.S. Geological Survey Water-Resources Investigations Report 97-4096, 60 p.
Council of Great Lakes Governors, 1985, The Great Lakes Charter-Principles for the management of Great Lakes Water Resources, February 11, 1985, 20 p., accessed September 3, 2009, at http://www.cglg.org/projects/water/docs/ GreatLakesCharter.pdf.

Dawson, Tom, 2003, Wisconsin law of groundwater withdrawal-A primer, in 2003 Wisconsin Lakes Convention, Green Bay, Wis., April 10-12, 2003, Proceedings: Madison, Wis., Wisconsin Department of Natural Resources-Wisconsin Groundwater Coordinating Council, Breakout Session A - Water supply - Will there be enough and why is getting enough becoming more and more difficult?, accessed July 10, 2008, at http://www.dnr.state.wi.us/org/water/dwg/gcc/ TD-TalkOutline.pdf.

East Central Wisconsin Regional Planning Commission, 2007, Demographic data center, accessed January 26, 2007, at http://www.eastcentralrpc.org/data_center/demographics. htm.

Ellefson, B.R., Mueller, G.D., and Buchwald, C.A., 2002, Water use in Wisconsin, 2000: U.S. Geological Survey Open-File Report 02-356, 1 sheet.

Ellefson, B.R., Rury, K.S., and Krohelski, J.T., 1987, Water use in Wisconsin, 1985: U.S. Geological Survey Open-File Report 87-699, 1 sheet.

Ellefson, B.R., Sabin, T.J., and Krohelski, J.T., 1993, Water use in Wisconsin, 1990: U.S. Geological Survey Open-File Report 93-118, 1 sheet.

Environmental Working Group, 2005, National Tap Water Quality Database, accessed September 8, 2009, at http:// www.ewg.org/tapwater/index.php.

Environmental Working Group, 2006, Farm Subsidy Database, accessed September 8, 2009, at http://farm.ewg.org/farm/ index.php.

Feinstein, D.T., Eaton, T.T., Hart, D.J., Krohelski, J.T., and Bradbury, K.R., 2005, Regional aquifer model for southeastern Wisconsin-Report 1-Data collection, conceptual model development, numerical model construction, and model calibration: Administrative report to the Southeastern Wisconsin Regional Planning Commission, Technical Report Number 41, 81 p.

Feinstein, D.T., Hart, D.J., Eaton, T.T., Krohelski, J.T., and Bradbury, K.R., 2004, Simulation of regional groundwater flow in southeastern Wisconsin: Wisconsin Geological and Natural History Survey Open-File Report 2004-01 [Groundwater flow model plus documentation], 1 CD-ROM.

Foley, F.C., Walton, W.C., and Drescher, W.J., 1953, Groundwater conditions in the Milwaukee-Waukesha area, Wisconsin: U.S. Geological Survey Water-Supply Paper 1229, 96 p. 
Forstall, R.L., ed., 1995, Wisconsin population of counties by decennial census - 1900 to 1990: U.S. Bureau of the Census-Population Division, data file, March 27, 1995, accessed December 6, 2006, at http://www.census.gov/ population/cencounts/wi190090.txt.

Green, J.H., and Hutchinson, R.D., 1965, Ground-water pumpage and water-level changes in the Milwaukee-Waukesha area, Wisconsin, 1950-61: U.S. Geological Survey WaterSupply Paper 1809-I, 19 p.

Gotkowitz, M., Hart, D., and Dunning, C., 2008, Groundwater sustainability in a humid climate-Groundwater pumping, groundwater consumption, and land-use change: Wisconsin Geologic and Natural History Survey, Open-File Report 2008-2, 47 p., 16 color pl. [Also on CD-ROM in PDF format.]

Hutchinson, R.D., 1970, Water resources of Racine and Kenosha Counties, southeastern Wisconsin: U.S. Geological Survey Water-Supply Paper 1878, 63 p.

Jansen, J.R., and Rao, M., 1998, Southeastern Wisconsin sandstone aquifer screening model report: Milwaukee, Wis., Bonestroo, Rosene, Anderlik and Associates, Inc., 62 p.

Knowles, D.B., 1964, Ground-water conditions in the Green Bay area, Wisconsin, 1950-60: U.S. Geological Survey Water-Supply Paper 1669-J, 37 p.

Knowles, D.B., Dreher, F.C., and Whetstone, G.W., 1964, Water resources of the Green Bay area, Wisconsin: U.S. Geological Survey Water-Supply Paper 1499-G, 67 p.

Krohelski, J.T., Bradbury, K.R., Hunt R.J., and Swanson, S.K., 2000, Numerical simulation of groundwater flow in Dane County, Wisconsin: Wisconsin Geological and Natural History Survey Bulletin 98, 31 p.

Lawrence, C.L., and Ellefson, B.R., 1982, Water use in Wisconsin, 1979: U.S. Geological Survey Open-File Report 82-444, 98 p.

Lawrence, C.L., Ellefson, B.R., and Cotter, R.D., 1984, Public-supply pumpage in Wisconsin, by aquifer: U.S. Geological Survey Open-File Report 83-931, 40 p.

LeRoux, E.F., 1957, Geology and ground-water resources of Outagamie County, Wisconsin: U.S. Geological Survey Water-Supply Paper 1421, 57 p.

Mandle, R.J., and Kontis, A.L., 1992, Simulation of regional ground-water flow in the Cambrian-Ordovician aquifer system in the northern Midwest, United States: U.S. Geological Survey Professional Paper 1405-C, 97 p.
Mathey, S.B., 1990, National water information system user's manual, v. 2, chap. 5, water use data system, pt. 1, Site Specific Water-use Data System (SSWUDS): U.S. Geological Survey Open-File Report 90-198, ver. 90.2 [variously paged].

Minnesota Department of Natural Resources, 2007, Water Appropriation Permit Program, accessed June 26, 2007, at http://www.dnr.state.mn.us/waters/watermgmt_section/ appropriations/wateruse.html.

Newport, T.G., 1962, Geology and ground-water resources of Fond du Lac County, Wisconsin: U.S. Geological Survey Water-Supply Paper 1604, 52 p.

Oconto County, 2007, Oconto County 20-year comprehensive plan, v. 2, County resources, chap. 6, Population and housing-Draft: UW-Extension, 21 p., accessed January 26, 2007, at http://www.uwex.edu/ces/cty/oconto/cnred/ documents/ch_6_housing_and_populationjune2007.pdf.

Olcott, P.G., 1966, Geology and ground-water resources of Winnebago County, Wisconsin: U.S. Geological Survey Water-Supply Paper 1814, 61 p.

Paulson, R.W., Chase, E.B., Roberts, R.S., and Moody, D.W., 1991, National water summary 1988-89-Hydrologic events and floods and droughts: U.S. Geological Survey Water-Supply Paper 2375, 591 p.

Public Service Commission of Wisconsin, 1985, Generating plants operated by Wisconsin electric utilities: Accounts and Finance Division Bulletin No. 46, August 1985, 10 p.

Reilly, T.E., Dennehy, K.F., Alley, W.M., and Cunningham, W.L., 2008, Ground-water availability in the United States: U.S. Geological Survey Circular 1323, 70 p., accessed September 8, 2009, at http://pubs.usgs.gov/circ/1323/.

Schmid, A.A., 1961, Water allocation by permit in Wisconsin: Madison, Wis., University of Wisconsin Press, Land Economics, v. 37, no. 2, p. 182-187.

Schmid, A.A., 1962, Water and the law in Wisconsin: Madison, Wis., Wisconsin Historical Society, Wisconsin Magazine of History, v. 45, no. 3, p. 203-215.

Soller, D.R., 1992, Text and references to accompany "Map showing the thickness and character of Quaternary sediments in the glaciated United States east of the Rocky Mountains": U.S. Geological Survey Bulletin 1921, 71 p.

Soller, D.R., and Packard, P.H., 1998, Digital representation of a map showing the thickness and character of Quaternary sediments in the glaciated United States east of the Rocky Mountains: U.S. Geological Survey Digital Data Series DDS-38. 
Southeastern Wisconsin Regional Planning Commission, 2004, The population of southeastern Wisconsin: Technical Report Number 11, July 2004, 114 p., accessed September 8, 2009, at http://maps.sewrpc.org/publications/techrep/ tr-011_population_southeastern_wisconsin.pdf.

Southeastern Wisconsin Regional Planning Commission, 2008, A regional water supply plan for southeastern Wisconsin, Chapter III-Existing water supply conditions in the region: Planning Report No. 52-Preliminary draft, accessed September 8, 2009, at http://www.sewrpc.org/ watersupplystudy/pdfs/pr-052_chapter-03_preliminary_ draft.pdf.

Southeastern Wisconsin Regional Planning Commission, 2010, Regional water supply plan, accessed May 17, 2010, at http://www.sewrpc.org/SEWRPC/Environment/RegionalWaterSupplyPlan.htm.

Southeastern Wisconsin Regional Planning Commission and Wisconsin Geological and Natural History Survey, 2002, Groundwater resources of southeastern Wisconsin: Technical Report Number 37, June 2002, 203 p., accessed September 8,2009 , at http://maps.sewrpc.org/publications/techrep/ tr-037_groundwater_resources.pdf.

Sun, R.J., Weeks, J.B., and Grubb, H.F., 1997, Bibliography of Regional Aquifer-Systems Analysis Program of the U.S. Geological Survey, 1978-96: U.S. Geological Survey Water-Resources Investigations Report 97-4074, 63 p., accessed September 8, 2009, at http://water.usgs.gov/ogw/ rasa/html/introduction.html.

Trotta, L.C., 1985, Depth to bedrock in Wisconsin: U.S. Geological Survey, in cooperation with Wisconsin Department of Natural Resources, scale 1:500,000.

U.S. Department of Agriculture, 1955, Irrigation-Water management guide for Wisconsin tentative for the design of sprinkler irrigation systems: Madison, Wis., Soil Conservation Service Information Circulars, $25 \mathrm{p}$.

U.S. Department of Agriculture, 1995, 1992 Census of agriculture, Volume 1, Part 49, Chapter 1-Wisconsin state and county data: Washington, D.C., National Agricultural Statistics Service, accessed November 24, 2009, at $h t t p: / / w w w$. agcensus.usda.gov/Publications/1992/Volume_1/Wisconsin/ wi_intro.pdf.

U.S. Department of Agriculture, 1999a, 1997 Census of agriculture, Volume 1, Part 49, Chapter 2-Wisconsin state and county level data: Washington, D.C., National Agricultural Statistics Service, accessed November 24, 2009, at http:// www.agcensus.usda.gov/Publications/1997/index.asp.

U.S. Department of Agriculture, 1999b, 1997 Census of agriculture, Farm and ranch irrigation survey (1998), Volume 3, Special Studies, Part 1: Washington, D.C., National Agricultural Statistics Service, AC97-SP-1, 148 p.
U.S. Department of Agriculture, 2004a, 2002 Census of agriculture, Volume 1, Chapter 2-County level data, Wisconsin: Washington, D.C., National Agricultural Statistics Service, accessed September 28, 2009, at http:// www.agcensus.usda.gov/Publications/2002/Volume_1, Chapter_2_County_Level/Wisconsin/index.asp.

U.S. Department of Agriculture, 2004b, 2002 Census of agriculture, Farm and ranch irrigation survey (2003), Volume 3, Special Studies, Part 1: Washington, D.C., National Agricultural Statistics Service, AC-02-SS-1, tables 12 and 28, 193 p.

U.S. Department of Agriculture-Farm Service Agency-Aerial Photography Field Office, 2006, Wisconsin county National Agriculture Imagery Program (NAIP) 2006 imagery, accessed May 9, 2006, at http://www.wisconsinview.org/.

U.S. Department of Commerce-Bureau of the Census, 1942, Sixteenth census of the United States, 1940-Agriculture, Volume I, First and Second Series State Reports-Part 1, Statistics for counties-Farms and farm property, with related information for farms and farm operators, livestock and livestock products, and crops, accessed September 8, 2009, at http://www.agcensus.usda.gov/Publications/ Historical_Publications/1940/Farms\%20and\%20Farm\%20 Property_New\%20England/00179375v1p1.pdf.

U.S. Department of Commerce-Bureau of the Census, 1952, United States census of agriculture, 1950-Irrigation of agricultural lands of the United States, Volume III, Enterprises, irrigation works, farms and acreage irrigated, investment, water used, and cost, accessed September 8, 2009, at http://www.agcensus.usda.gov/Publications/Historical_ Publications/1950/vol3\%20irrigated\%20lands/38921062v3. pdf.

U.S. Department of Commerce-Bureau of the Census, 1956, United States census of agriculture, 1954-Volume 1, Counties and state economic areas-Part 7, Wisconsin: Washington, D.C., U.S. Government Printing Office, p. $108-113$.

U.S. Department of Commerce-Bureau of the Census, 1961, United States census of agriculture, 1959-Volume I, Counties-Part 14, Wisconsin: Washington, D.C., U.S. Government Printing Office, 211 p.

U.S. Department of Commerce-Bureau of the Census, 1972, Census of agriculture, 1969-Volume 1, Area reports-Part 14, Wisconsin section 1 summary data and section 2 county data: Washington, D.C., U.S. Government Printing Office, $576 \mathrm{p}$.

U.S. Department of Commerce-Bureau of the Census, 1977, United States census of agriculture, 1974-Volume 1, State and county data—Part 49, Wisconsin: Washington, D.C., U.S. Government Printing Office [variously paged]. 
U.S. Department of Commerce-Bureau of the Census, 1982, United States census of agriculture, 1978-Volume 1, State and county data-Part 49, Wisconsin: Washington, D.C., U.S. Government Printing Office, AC78-A-49 [variously paged].

U.S. Department of Commerce-Bureau of the Census, 1990a, United States census of agriculture, 1987-Volume 1, Geographic areas series-Part 49, Wisconsin state and county data: Washington, D.C., U.S. Government Printing Office, p. 220-229.

U.S. Department of Commerce-Bureau of the Census, 1990b, 1987 Census of agriculture, Farm and ranch irrigation survey (1988), Volume 3, Special Studies Part 1: Washington, D.C., 114 p.

U.S. Department of Commerce-Bureau of the Census, 2006, Population estimates, County population datasets, Population data by county for 2000, accessed March 21, 2006, at http://www.census.gov/popest/datasets.html.

U.S. Department of Energy-Energy Information Administration, 2006, EIA-767 Data Files-Annual Steam-Electric Plant Operation and Design Data (1996-2005), accessed June 26, 2006, at http://www.eia.doe.gov/cneaf/electricity/ pageleia $767 . \mathrm{html}$.

U.S. Environmental Protection Agency, 2006, Safe Drinking Water Information System (SDWIS), accessed March 23, 2007, at http://oaspub.epa.gov/enviro/sdw_form_v2.create page?state_abbr $=W I$.

U.S. Geological Survey, ed. [various dates], The National Map-Digital orthoimagery, accessed September 28, 2009, at $h t t p: / / s e a m l e s s . u s g s . g o v / i n d e x . p h p$.

U.S. Geological Survey, 1998, National Water Information System (NWIS): U.S. Geological Survey Fact Sheet FS-027-98, 2 p., accessed September 28, 2009, at http:// pubs.usgs.gov/fs/FS-027-98/.

U.S. Geological Survey Wisconsin Water Science Center, 2009, Groundwater systems team current projects, accessed November 24, 2009, at http://wi.water.usgs.gov/groundwater/projects.html.

Vickers, Amy, 2001, Water use and conservation-Homes, landscapes, businesses, industries, farms: Amherst, Mass., Waterplow Press, 446 p.

Walker, J.F., Saad, D.A., and Krohelski, J.T., 1998, Optimization of ground-water withdrawal in the Lower Fox River communities, Wisconsin: U.S. Geological Survey WaterResources Investigations Report 97-4218, 24 p.
Wisconsin Department of Administration-Demographic Services Center, 2006, Table - Time series of the final official population estimates and census counts for Wisconsin municipalities in existence on January 1, 2006, accessed December 6, 2006, at http://www.doa.state.wi.us/section detail.asp?linkcatid $=11 \&$ linkid $=64$ \&locid $=9$.

Wisconsin Department of Agriculture, [1948], A century of Wisconsin agriculture, 1848-1948: Wisconsin Department of Agriculture Bulletin no. 290, 119 p.

Wisconsin Department of Natural Resources, 1997, Status of groundwater quantity in Wisconsin: PUBL-DG-043-97, accessed September 28, 2009, at http://www.dnr.state.wi.us/ org/water/dwg/gcc/gw-quantity.pdf.

Wisconsin Department of Natural Resources, 2005, Groundwater retrieval network and high capacity well database: Bureau of Drinking Water and Groundwater, accessed December 7, 2005, at http://prodoasext.dnr.wi.gov/inter1/ hicap\$.startup.

Wisconsin Department of Natural Resources, 2006, Water well data CD-ROM: Madison, Wis., Bureau of Drinking Water and Groundwater, ver. 2, July 2006.

Wisconsin Department of Natural Resources, 2007, Water well data CD-ROM: Madison, Wis., Bureau of Drinking Water and Groundwater, ver. 3, July 2007.

Wisconsin Department of Natural Resources, 2008a, High capacity well program: Madison, Wis., Bureau of Drinking Water and Groundwater, accessed October 30, 2008, at http://dnr.wi.gov/org/water/dwg/hicap.html.

Wisconsin Geological and Natural History Survey, 1983, Thickness of unconsolidated material in Wisconsin: University of Wisconsin Extension, Wisconsin Geological and Natural History Survey page-size map series number 18.

Wisconsin Geological and Natural History Survey, 2004, wiscLITH—A digital lithologic and stratigraphic database of Wisconsin geology: Wisconsin Geological and Natural History Survey Open-File Report 2003-05, ver. 2.0, 1 CDROM.

Wisconsin Geological and Natural History Survey, 2008, Geology research projects: University of Wisconsin Extension, accessed August 21, 2008, at http://www.uwex.edu/ wgnhs/proj_geol.htm.

Wisconsin State Climatology Office, 2009, Long-term variability of annual climate-Statewide annual precipitation (1895-present), accessed September 29, 2009, at http:// www.aos.wisc.edu/ sco/clim-history/state/index.html.

Wisconsin State Legislature, 2004, 2003 Wisconsin Act 310, accessed September 29, 2009, at http://www.legis.state. wi.us/2003/data/acts/03Act310.pdf. 
Wisconsin State Legislature, 2007, Chapter NR 820-Groundwater quantity protection: Register, August 2007, no. 620, p. 233-237, accessed September 29, 2009, at http://www.legis. state.wi.us/rsb/code/nr/nr820.pdf.

Wisconsin State Legislature, 2009, Text from Legislative Reference Bureau database of 2007-08 Wisconsin statutes and annotations updated through August 17, 2009, and 2009 Wisconsin Act 39-Chapters 60, 61, 62, 66, and 200, accessed September 29, 2009, at http://nxt.legis. state.wi.us/nxt/gateway.dll?f=templates \& $f n=$ default. htm\&d=stats\&jd=top.

Young, H.L., 1992, Hydrogeology of the Cambrian-Ordovician aquifer system in the northern Midwest, United States: U.S. Geological Survey Professional Paper 1405-B, 99 p.

\section{Michigan References}

Baltusis, M.A., Quigley, M.F., and Mandle, R.J., 1992, Municipal ground-water development and withdrawals in the central lower peninsula of Michigan, 1870-1987: U.S. Geological Survey Open-File Report 91-215, 89 p.

Bauder, Jim, and Carlson, Linzy, 2005, Soil moisture monitoring-What does $65 \%$ depletion mean?: Montana State University, Department of Land Resources and Environmental Sciences, Water Quality and Irrigation Management, accessed August 17, 2007, at http://waterquality.montana. edu/docs/irrigation/depletion.shtml.

Bedell, D.J., 1982, Municipal water withdrawals in Michigan: Michigan Department of Natural Resources, Water Management Division, $43 \mathrm{p}$.

Holtschlag, D.J., Luukkonen, C.L., and Nicholas, J.R., 1996, Simulation of ground-water flow in the Saginaw aquifer, Clinton, Eaton, and Ingham Counties, Michigan: U.S. Geological Survey Water-Supply Paper 2480, 49 p.

Huffman, G.C., 1974a, Summary of ground-water hydrological data in Michigan in 1972: U.S. Geological Survey Report (unnumbered), $90 \mathrm{p}$.

Huffman, G.C., 1974b, Ground-water data for Michigan, 1973: U.S. Geological Survey Report (unnumbered), 86 p.

Huffman, G.C., 1975, Ground-water data for Michigan, 1974: U.S. Geological Survey Report (unnumbered), 89 p.

Huffman, G.C., 1976, Ground-water data for Michigan, 1975: U.S. Geological Survey Open-File Report 77-139, 56 p.

Huffman, G.C., 1977, Ground-water data for Michigan, 1976: U.S. Geological Survey Open-File Report 77-782, 56 p.

Huffman, G.C., 1979a, Ground-water data for Michigan, 1977: U.S. Geological Survey Open-File Report 79-332, 75 p.
Huffman, G.C., 1979b, Ground-water data for Michigan, 1978: U.S. Geological Survey Open-File Report 80-002, $61 \mathrm{p}$.

Huffman, G.C., 1980, Ground-water data for Michigan, 1979: U.S. Geological Survey Open-File Report 80-1212, 56 p.

Huffman, G.C., 1981, Ground-water data for Michigan, 1980: U.S. Geological Survey Open-File Report 81-811, 57 p.

Huffman, G.C., 1982, Ground-water data for Michigan, 1981: U.S. Geological Survey Open-File Report 82-754, 55 p.

Huffman, G.C., 1983, Ground-water data for Michigan, 1982: U.S. Geological Survey Open-File Report 83-753, 54 p.

Huffman, G.C., 1984, Ground-water data for Michigan, 1983: U.S. Geological Survey Open-File Report 84-623, 47 p.

Huffman, G.C., 1985, Ground-water data for Michigan, 1984: U.S. Geological Survey Open-File Report 85-420, 50 p.

Huffman, G.C., 1986, Ground-water data for Michigan, 1985: U.S. Geological Survey Open-File Report 86-417W, 50 p.

Huffman, G.C., 1988, Ground-water data for Michigan, 1986: U.S. Geological Survey Open-File Report 88-87, 52 p.

Huffman, G.C., and Thompson, T., 1971, Summary of groundwater hydrological data in Michigan in 1970: U.S. Geological Survey Open-File Report 72-173, 94 p.

Huffman, G.C., and Thompson, T., 1973, Summary of groundwater hydrological data in Michigan in 1971: U.S. Geological Survey Report (unnumbered), 88 p.

Huffman, G.C., and Whited, C.R., 1988, Ground-water data for Michigan, 1987: U.S. Geological Survey Open-File Report 88-704, 56 p.

Huffman, G.C., and Whited, C.R., 1989, Ground-water data for Michigan, 1988: U.S. Geological Survey Open-File Report 89-597, 54 p.

Huffman, G.C., and Whited, C.R., 1991, Ground-water data for Michigan, 1989: U.S. Geological Survey Open-File Report 91-55, $51 \mathrm{p}$.

Huffman, G.C., and Whited, C.R., 1993, Ground-water data for Michigan, 1990: U.S. Geological Survey Open-File Report 92-114, 51 p.

Luukkonen, C.L., Blumer, S.P., Weaver, T.L., and Jean, Julie, 2004, Simulation of the ground-water-flow system in the Kalamazoo County area, Michigan: U.S. Geological Survey Scientific Investigations Report 2004-5054, 65 p.

Luukkonen, C.L., and Westjohn, D.B., 2001, Ground-water flow and contributing areas to public-supply wells in Kingsford and Iron Mountain, Michigan: U.S. Geological Survey Water-Resources Investigations Report 00-4226, 43 p. 
Michigan Department of Environmental Quality, 2004, Water withdrawals for self-supplied industrial manufacturing in Michigan 2004, accessed July 14, 2009, at $h t t p: / / w w w . d e q$. state.mi.us/documents/deq-wd-wurp-Industrial04.pdf

Michigan Department of Environmental Quality, 2005a, Water use, levels, \& diversion Web site, accessed November 22, 2005, at http://www.michigan.gov/deq/0,1607,7-1353313_3677_3704---,00.html.

Michigan Department of Environmental Quality, 2005b, Public Act 148 - Groundwater Inventory and Map (GWIM) Project, Executive Summary, 31 p., accessed September 29, 2009, at http://www.michigan.gov/documents/dnr/public act148_aug_2005_270734_7.pdf.

Michigan Department of Environmental Quality, 2006a, State of Michigan Public Act 148 - Groundwater Inventory and Map (GWIM) Project, Technical Report, 257 p., accessed September 29, 2009, at http://gwmap.rsgis.msu.edu/ Technical_Report.pdf.

Michigan Department of Environmental Quality, 2006b, Water withdrawals for agricultural irrigation in Michigan 2006, accessed July 14, 2009, at http:// www.michigan.gov/documents/deq/deq-wd-wurpagriculturereport06_208259_7.pdf.

Michigan Department of Environmental Quality, 2006c, Groundwater mapping project website, accessed September 29, 2009, at http://gwmap.rsgis.msu.edu/.

Michigan Department of Environmental Quality, 2006d, Water withdrawals for golf course irrigation in Michigan 2004, accessed July 14, 2009, at http://www.deq.state.mi.us/ documents/deq-wd-wurp-golf04.pdf.

Michigan Department of Health, 1961, Data on public water supplies in Michigan: Engineering Bulletin No. 4, 57 p.

Michigan Department of Public Health, 1943, Public water supplies in Michigan: Engineering Bulletin No. 12, Section 1.

Michigan State University Extension, 1998, Changes in Michigan agriculture-1950 to 1987: by Richard H. Bernsten, accessed March 10, 2009, at http://web1.msue.msu.edu/imp/ modsr/sp000001.html.

National Climatic Data Center, 2005, Daily surface data: Asheville, N.C., accessed August 16, 2007, at http://www. ncdc.noaa.gov/oa/ncdc.html.

Shayya, W.H., and Bralts, V.F., 1994, Guide to SCS-Microcomputer Irrigation Scheduling Package, SCS-Scheduler Version 3.00: Michigan State University, Department of Agricultural Engineering, $341 \mathrm{p}$.

U.S. Department of Agriculture-Soil Conservation Service, 1994, State Soil Geographic (STATSGO) database for Michigan: Fort Worth, Tex., electronic GIS data, 1:250,000 scale.
U.S. Department of Commerce-Bureau of the Census, 1927, United States census of agriculture, 1925-Part I, Northern states: Washington, D.C., U.S. Government Printing Office, p. 587-630.

U.S. Department of Commerce-Bureau of the Census, 1932, Fifteenth census of the United States, 1930 - Census of agriculture, Volume II-Part 1, The northern states: Washington, D.C., U.S. Government Printing Office, p. 657-704.

U.S. Department of Commerce-Bureau of the Census, 1942, Sixteenth census of the United States, 1940 - Census of agriculture, Volume I, First and second series state reportsPart 1, Statistics for counties: Washington, D.C., U.S. Government Printing Office, p. 786-872.

U.S. Department of Commerce-Bureau of the Census, 1946, United States census of agriculture, 1945-Volume 1, Part 6, Michigan, statistics for counties: Washington, D.C., U.S. Government Printing Office, p. 18-91.

U.S. Department of Commerce-Bureau of the Census, 1952, United States census of agriculture, 1950-Volume 1, Counties and state economic areas-Part 6, Michigan: Washington, D.C., U.S. Government Printing Office, p. 42-98.

U.S. Department of Commerce-Bureau of the Census, 1956, United States census of agriculture, 1954-Volume 1, Counties and state economic areas-Part 6, Michigan: Washington, D.C., U.S. Government Printing Office, p. 44-132.

U.S. Department of Commerce-Bureau of the Census, 1961, United States census of agriculture, 1959-Volume 1, Counties-Part 13, Michigan: Washington, D.C., U.S. Government Printing Office, p. 134-230.

U.S. Department of Commerce-Bureau of the Census, 1967, United States census of agriculture, 1964-Volume 1, State and county statistics-Part 13, Michigan: Washington, D.C., U.S. Government Printing Office, p. 258-383.

U.S. Department of Commerce-Bureau of the Census, 1971, United States census of agriculture, 1969-Volume 1, Area reports-Part 13, Michigan-Section 2, County data: Washington, D.C., U.S. Government Printing Office, p. 300-313.

U.S. Department of Commerce-Bureau of the Census, 1977, United States census of agriculture, 1974-Volume 1, State and county data-Part 22, Michigan: Washington, D.C., U.S. Government Printing Office, p. II-1-II-45.

U.S. Department of Commerce-Bureau of the Census, 1982, 1982 Census of manufacturing, Subject series, Water use in manufacturing: Washington, D.C., U.S. Government Printing Office [variously paged].

U.S. Department of Commerce-Bureau of the Census, 1982, United States census of agriculture, 1978- Volume 1, State and county data-Part 22, Michigan: Washington, D.C., U.S. Government Printing Office, p. 118-166. 
U.S. Department of Commerce-Bureau of the Census, 1984, United States census of agriculture, 1982-Volume 1, Geographic areas series - Part 22, Michigan state and county data: Washington, D.C., U.S. Government Printing Office, p. 120-371.

U.S. Department of Commerce-Bureau of the Census, 1990, United States census of agriculture, 1987- Volume 1, Geographic areas series-Part 22, Michigan state and county data: Washington, D.C., U.S. Government Printing Office, p. 197-340.

U.S. Department of Commerce-Bureau of the Census, 1992, 1992 Census of manufacturers, Geographic area series, Michigan: Washington, D.C., U.S. Government Printing Office [variously paged].

\section{Indiana References}

Arvin, D.V., and Spaeth, Ralph, 2009, Trends in Indiana's water use, 1986-96: State of Indiana, Department of Natural Resources, Division of Water, Special Report No. 1, 19 p., accessed September 29, 2009, at http://www.in.gov/dnr/ water/files/trendstext.pdf.

Indiana Department of Natural Resources, 1987, Water resource availability in the St. Joseph River Basin, Indiana: Indianapolis, Ind., Water Resource Assessment 87-1.

Indiana Department of Natural Resources, 1990, Water resource availability in the Kankakee River Basin, Indiana: Indianapolis, Ind., Water Resource Assessment 90-3.

Indiana Department of Natural Resources, 1994, Water resource availability in the Lake Michigan Region, Indiana: Indianapolis, Ind., Water Resource Assessment 94-4.

Indiana Department of Natural Resources, 1996, Water resource availability in the Maumee River Basin, Indiana: Indianapolis, Ind., Water Resource Assessment 96-5.

Indiana Department of Natural Resources, 2008, Utilization of the water resource, accessed July 16, 2008, at http://www. in.gov/dnr/water/files/804_Util_Water_Res.pdf.

Indiana Department of Natural Resources, 2009a, Groundwater availability, accessed July 14, 2009, at http://www. in.gov/dnr/water/3650.htm.

Indiana Department of Natural Resources, 2009b, Water well record database, accessed July 14, 2009, at http://www. in.gov/dnr/water/3595.htm.

Klaer, F.H., Jr., and Stallman, R.W., 1948, Ground-water resources of Saint Joseph County, Indiana: Indiana Department of Conservation-Division of Water Resources Bulletin No. 3.
Stallman, R.W., and Klaer, F.H., Jr., 1950, Ground-water resources of Noble County, Indiana: Indiana Department of Conservation-Division of Water Resources Bulletin No. 5.

\section{Illinois References}

Beck, R., Harrington, K.W., Hardy, W.P., and Feather, T.D., 1996, Assessment of Illinois water quantity law: Planning and Management Consultants, Ltd., report submitted to Illinois Department of Natural Resources-Office of Water Resources, July 1996, accessed December 19, 2008, at http://www.isws.uiuc.edu/iswsdocs/wsp/ IlWaterQuantityLaw.pdf.

Burch, S.L., 1991, The new Chicago model-A reassessment of the impacts of Lake Michigan allocations on the Cambrian-Ordovician aquifer system in northeastern Illinois: Champaign, Ill., Illinois State Water Survey Research Report 119, 58 p.

Clark, G.R., 1985, Illinois groundwater law-The rule of reasonable use-A report to the Illinois Groundwater Association, October 8, 1985: Joliet, Ill., Illinois Department of Transportation-Division of Water Resources, September 18, 1985 (draft), accessed December 19, 2008, at http://www. isws.illinois.edu/iswsdocs/wsp/IllinoisGroundwaterLaw.pdf.

Kenny, J.F., ed., 2004, Guidelines for preparation of State water-use estimates for 2000: U.S. Geological Survey Techniques and Methods Report 4-A4, 49 p., accessed October 1, 2009, at http://pubs.usgs.gov/tm/2005/tm4A4/.

Illinois General Assembly, 1984, Water Use Act of 1983, Public Act 83-700, approved September 23, 1983, effective January 1, 1984, Text from the Illinois Legislative Information System for Illinois Compiled Statutes, Chapter 525 Conservation-Statute 45 (525 ILCS 45/), at http://www. ilga.gov/legislation/ilcs/ilcs.asp.

Illinois State Water Survey and Hittman Associates, 1973, Feasibility study on desalting brackish water from the Mt. Simon aquifer in northeastern Illinois: Champaign, Ill., Illinois State Water Survey Contract Report 153, 120 p.

Prickett, T.A., and Lonnquist, C.G., 1971, Selected digital computer techniques for groundwater resource evaluation: Champaign, Ill., Illinois State Water Survey Bulletin 55, 62 p.

Sasman, R.T., Prickett, T.A., and Russell, R.R., 1961, Waterlevel decline and pumpage during 1960 in deep wells in the Chicago Region, Illinois: Illinois State Water Survey Circular 83, 43 p. 
Sun, R.J., Weeks, J.B., and Grubb, H.F., 1997, Bibliography of Regional Aquifer-Systems Analysis Program of the U.S. Geological Survey, 1978-96: U.S. Geological Survey Water-Resources Investigations Report 97-4074, 63 p., accessed October 1, 2009, at http://water.usgs.gov/ogw/ rasa/html/introduction.html.

Suter, M., Bergstrom, R.E., Smith, H.F., Emrich, G.H., Walton, W.C., and Larson, T.E., 1959, Preliminary report on the ground-water resources of the Chicago Region, Illinois: Champaign-Urbana, Ill., Illinois State Water Survey and Illinois State Geological Survey Cooperative Ground-Water Report 1,89 p.

Young, H.L., 1992, Hydrogeology of the Cambrian-Ordovician aquifer system in the northern Midwest, United States: U.S. Geological Survey Professional Paper 1405-B, 99 p. 



\section{Glossary}

\section{A}

agricultural irrigation Refers to water applied artificially to the growing of nonspecialty crops, specifically grains, grasses, legumes, and vegetables.

aquaculture water use Water used in the production of organisms that live in water within a confined space and under controlled feeding, sanitation, and harvesting procedures, and establishments primarily engaged in hatching fish and in operating fishing preserves.

aquifer In general terms, underground soil or rock through which groundwater can easily move. More specifically, a geologic formation, group of formations, or part of a formation that contains sufficient saturated permeable material to yield significant quantities of water to wells or springs. See also groundwater.

\section{B}

C

coefficient A mathematical term for a number (quantity) placed before and multiplying another number (quantity).

commercial water use Water used at facilities involved in the sale of goods or services, such as hotels, restaurants, office buildings, hospitals, schools, and civilian and military institutions.

community A collaboration of people living together in a particular location. A community may or may not be incorporated with governing oversight. All communities considered in this report must have at least 25 year-round residents. Examples of communities are neighborhood suburbs, mobile home parks, townships, or cities.

community withdrawal Refers to water withdrawals for a community. See also community and water withdrawal.
D

default water withdrawal rate The amount of water that has been estimated and substituted for withdrawal site (for example, well, facility) having no reported water-use data.

E

energy production water use (Indiana-specific definition) A water-use category in Indiana for water withdrawn for the primary purpose of power generation including coal mining operations or for the cooling of condensers at fossil fuel plants. See also thermoelectricpower water use.

F

farfield model area Outer area of the Lake Michigan Basin groundwater-flow model beyond the Lake Michigan Basin boundary, composed of cells with larger grid spacing.

\section{G}

golf course irrigation Refers to water applied artificially at golf courses for uses such as to maintain turfgrass or fill water hazards.

groundwater Generally all subsurface water as distinct from surface water; specifically, that part of the subsurface water in the saturated zone (a zone in which open spaces are filled with water).

groundwater-flow model A numerical representation used to simulate how water or chemical solutes move through local and regional aquifers. This representation consists of one or more model layers.

groundwater withdrawal Removal of water from a groundwater source such as an aquifer. The water that is supplied by a well or spring. See also aquifer. 
H

high capacity Refers to the flow rate of a water withdrawal that is at or above a defined threshold. This rate is specific to each state. For example, in Wisconsin, it is when the total pumping or flowing capacity of all wells, drill holes, or mine shafts on one property is 70 or more gallons per minute, or, in Illinois, it is when a withdrawal is 100,000 gallons or more a day.

high-capacity property In general, means a property that is able of withdrawing water at a high-capacity flow rate. Specifically for Wisconsin, means a property where there is a well or wells that have a pumping capacity, in aggregate, able of withdrawing water at a rate of 70 or more gallons per minute.

high-capacity well A well constructed that meets the state-defined criteria for what is considered high capacity or a well constructed on a high-capacity property. See also high capacity and high-capacity property.

high-capacity well approval The review and positive determination of an application for high-capacity water withdrawal by a state authorizing department. Prior approval is also necessary before a high-capacity well or water-supply system can be operated. This especially applies after a change of ownership. An approval is not the same as a high-capacity well permit. See also high capacity, highcapacity well permit, and water withdrawal.

housing subdivision Means the division of a lot, tract, or parcel of land into two or more lots, plats, sites, or other divisions of land for the purpose of building residences.

hydrogeologic unit Any rock unit or zone of identifiable origin and age range that because of its hydraulic properties has a distinct influence on the storage or movement of groundwater. See also groundwater.

hydrogeologic unit model layer Hydrogeologic units that have been assigned to a model layer of the groundwater-flow model. See also groundwater-flow model, hydrogeologic unit, and model layer.

\section{I}

incorporated place A community that has grouped together to create a political decisionmaking structure by typically a governing body. See also community.

industrial water use Water used for industrial purposes, such as manufacturing, fabrication, processing, washing, and cooling.

irrigation water use Water applied to lands to assist in the growing of crops and pastures or to maintain vegetative growth on recreational lands such as parks and golf courses.

J

K

$\mathbf{L}$

M

miscellaneous water use A report-specific water-use category for water withdrawn in Wisconsin for a variety of uses. Miscellaneous water use in Wisconsin includes aquaculture and thermoelectric-power water uses. The above-listed uses were categorized differently for Michigan, Indiana, and Illinois due to how data are collected, classified, and estimated for each state. See also aquaculture water use and thermoelectric-power water use.

model layer How aquifers or hydrogeologic units are represented in the groundwater-flow model. See also groundwater-flow model and hydrogeologic unit.

model subregion (or subregion) Area of the Lake Michigan Basin groundwater-flow model corresponding to one of the following geographical areas: Northeastern Wisconsin, Southeastern Wisconsin, Northeastern Illinois, Upper Peninsula of Michigan, Northern Lower Peninsula of Michigan, Southern Lower Peninsula of Michigan, and Northern Indiana.

municipal Public ownership and access that is authorized by a local or state government. 
$\mathbf{N}$

nearfield model area Central area of the Lake Michigan Basin groundwater-flow encompassing the Lake Michigan Basin and composed of cells with smaller grid spacing.

\section{0}

other irrigation (Wisconsin-specific definition) Other irrigation refers to water applied artificially at athletic fields, cemeteries, and golf courses, or for other landscaping needs.

other water use (Indiana-specific definition) A water-use category in Indiana for water withdrawn for a variety of uses, including snow-making, aquaculture, operating fish and wildlife areas, lake-level maintenance, and construction dewatering. Landfills were included in this category until 1996. See also aquaculture water use, rural water use, and thermoelectric-power water use.

\section{$\mathbf{P}$}

per capita water use (per capita use) The average amount of water used per person during a standard time period, usually one day.

principal crop irrigation See agricultural irrigation.

public-supply water use Water withdrawn by public and private water suppliers that furnish water to as least 25 people or have a minimum of 15 connections year-round or for Wisconsin at least 60 days per year. Public supply provides water for a variety of uses, such as domestic, commercial, industrial, thermoelectric power, and public water use.

\section{public water-supply system (or water}

supplier) A utility or another provider that delivers water through a water conveyance system in a community for use by the public. See also community and public-supply water use. $\mathbf{0}$

R

rural water use (Indiana-specific

definition) A water-use category in Indiana for water withdrawals with the primary purpose of watering livestock and operating fish hatcheries.

S

self-supplied water use Water withdrawn from a groundwater source by a user rather than being obtained from a public supply. All self-supplied water use in this report is from groundwater sources.

significant water withdrawal The amount of water that is considered large. Legislation under each state can define the amount or withdrawal rate that is important as it may have effect on local water resources. For example, a significant water withdrawal from a groundwater source in Michigan is from a well capable of producing 100,000 gallons or more per day; whereas in Wisconsin, it is from a property with a well having a withdrawal rate of 70 gallons or more per minute.

specialty agricultural irrigation (Wisconsinspecific definition) Specialty agriculture irrigation refers to water applied artificially to assist with the growing of non-standard crops or ornamental products typically found at tree farms, orchards, nurseries, and greenhouses, which includes the growing of berries, sod, mint, ginseng, commercial seeds, flowers, and mushrooms.

subregion See model subregion.

\section{$\mathbf{T}$}

thermoelectric-power water use Water used in the process of generating electricity with steam-driven turbine generators. 
time interval Discrete intervals of time used in a groundwater-flow model (also known as stress periods). For the Lake Michigan Basin groundwater-flow model the following 12 time intervals were used: (1) 1864-1900; (2) $1901-20$; (3) $1921-40$; (4) 1941-50; (5) 1951-60; (6) 1961-70; (7) 1971-75; (8) 1976-80; (9) 1981-85; (10) 1986-90; (11) 1991-2000; and (12) 2001-05.

\section{$\mathbf{U}$}

unconsolidated material A mixture of loose material composed of sand, gravel, silt or clay. The source of this material may be from alluvial, eluvial, or glacial origins. It is also sometimes referred to as unlithified deposits or deposits of a specific geologic time period such as Quaternary deposits.

\section{V}

W

water supplier See public water-supply system. water use Water that is used for a specific purpose, such as for domestic use, irrigation, or industrial processing.

water withdrawal Removal of water from either a surface water or groundwater source. All withdrawals in this report are from groundwater sources. See also groundwater withdrawal.

well permit (Wisconsin-specific definition) Means authorization for a well location or pump installation that is considered high capacity. This permission is obtained from the Wisconsin Department of Natural Resources although in some counties extra permits are required through other government agencies. A permit is not the same as a highcapacity well approval. See also high capacity and high-capacity well approval.

$\mathbf{X}$

Y

Z 


\section{Appendixes}

1. Stratigraphic columns for Wisconsin, Illinois, Indiana, Ohio, and Michigan and assigned hydrogeologic-unit model layers and aquifer systems.

2. Wisconsin water-use category estimates by time interval and $A$, model subregion;

$B$, aquifer system; and $C$, aquifer type

3. Michigan water-use category estimates by time interval and $A$, model subregion;

$B$, aquifer system; and $C$, aquifer type...... . .96

4. Indiana water-use category estimates by time interval and $A$, model subregion; $B$, aquifer system; and $C$, aquifer type.

5. Illinois water-use category estimates by time interval and $A$, model subregion; $B$, aquifer system; and $C$, aquifer type

6. Water-use estimates for 2040 :

A. Estimation methods for 2040 water use 105

B. Lake Michigan Basin model time interval 12 (2001-5) and 2040 groundwateruse estimates by category, model subregion, and aquifer system..............................111

C. Methods for estimating 2040 water use by category and state.....................................113

D. References used in the estimation of 2040 water use, by state ...................................115

E. Adjusted model rates and estimated percent change in employment for Wisconsin industrial water-use projections for the year 2040 


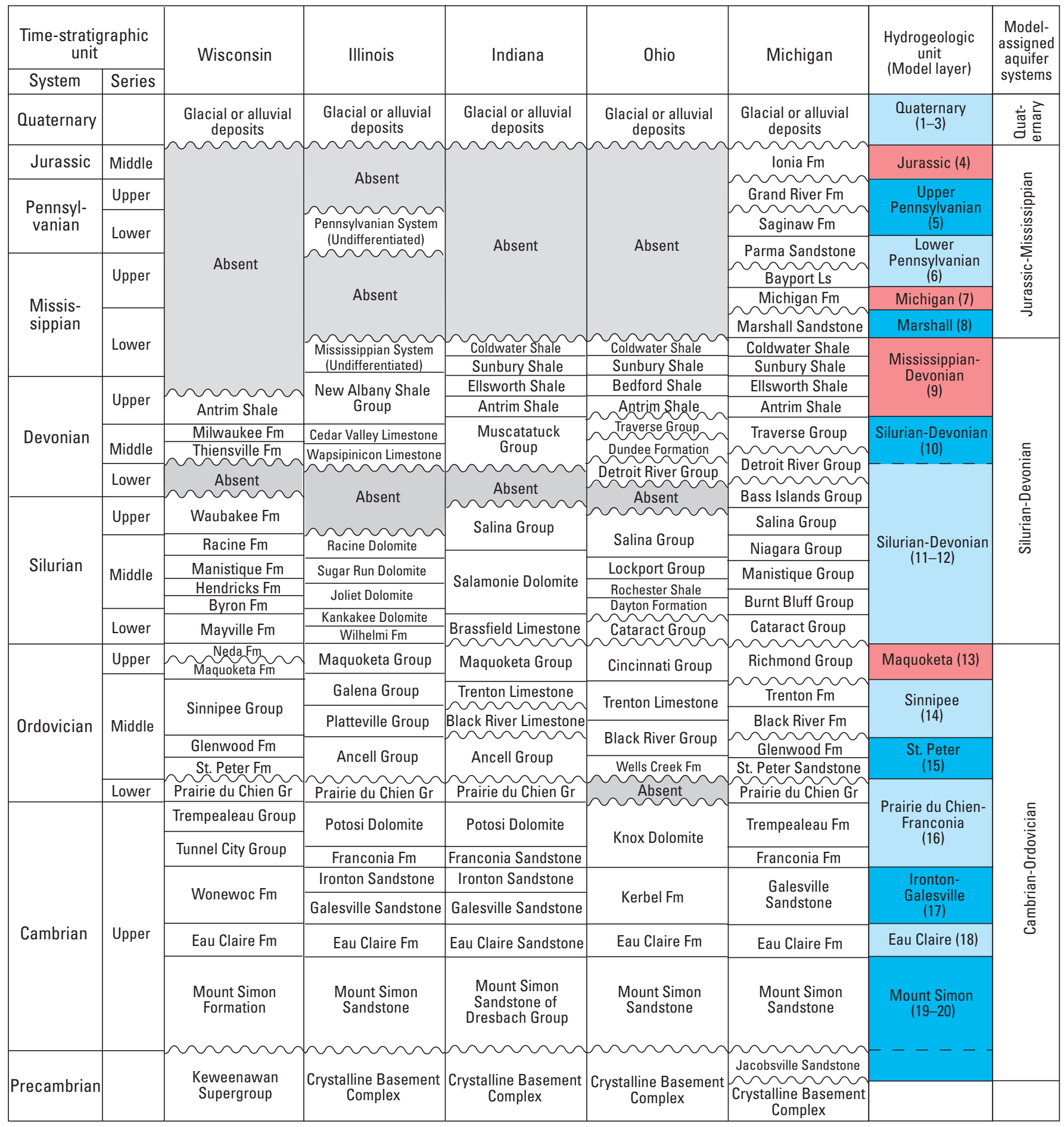

Reference: Modified stratigraphic columns from Lampe, 2009

Abbreviations: Group (Gr), Formation (Fm), Limestone (Ls), feet (ft)

\section{EXPLANATION}

Aquifer

Confining unit

Aquifer/Confining unit
The following hydrogeologic units, if present, were subdivided into multiple model layers based on unit thickness:

Quaternary: layer 1 (0-100 ft); layer 2 (100-200 ft); and layer 3 (more than $300 \mathrm{ft}$ )

Silurian-Devonian: layer $10(0-50 \mathrm{ft})$; layer $11(50-300 \mathrm{ft})$; and layer 12 (more than $300 \mathrm{ft})$

Mount Simon: layer 19 (0-300 ft) and layer 12 (more than $300 \mathrm{ft}$ )

Appendix 1. Stratigraphic columns for Wisconsin, Illinois, Indiana, Ohio, and Michigan and assigned hydrogeologic-unit model layers and aquifer systems. 


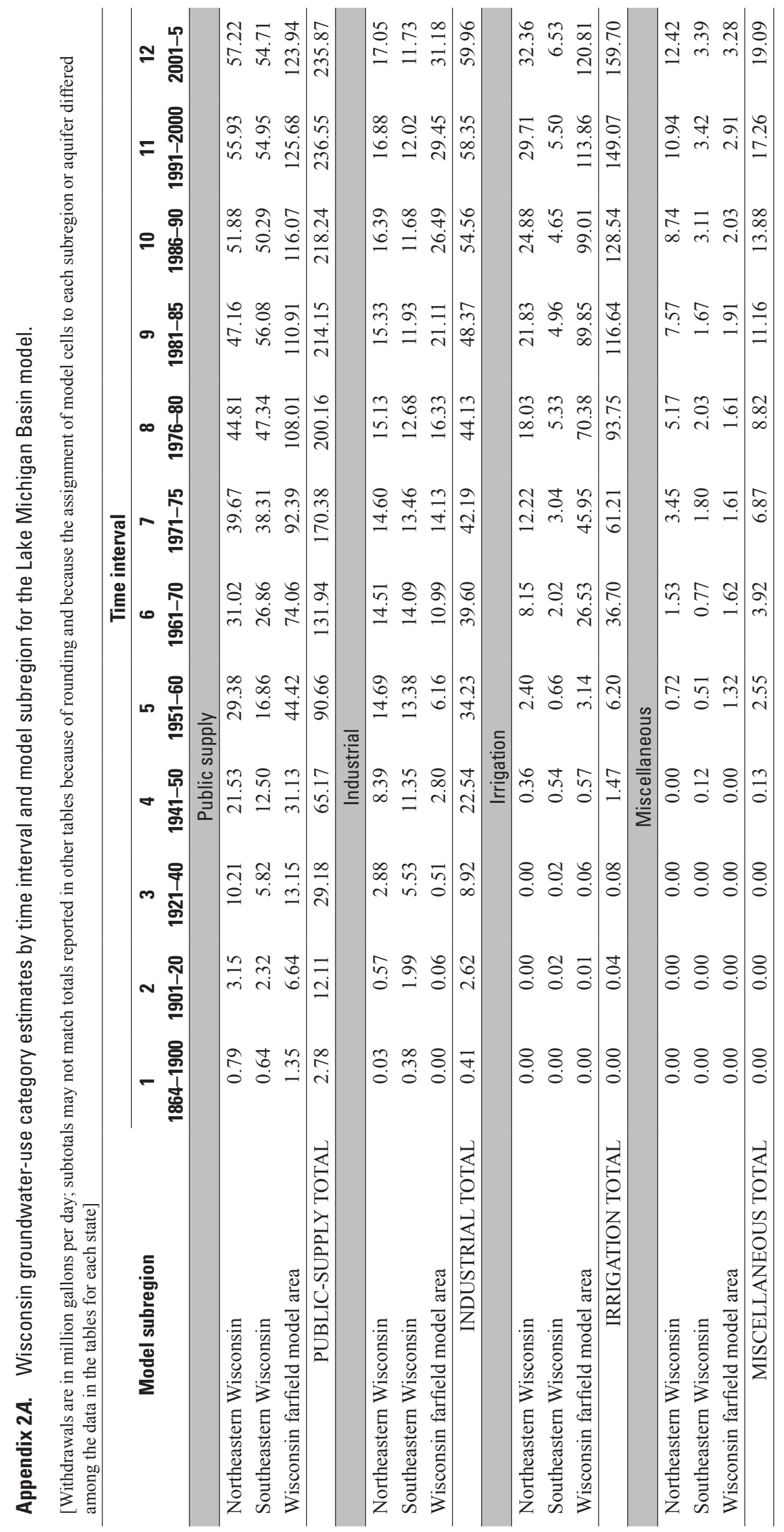




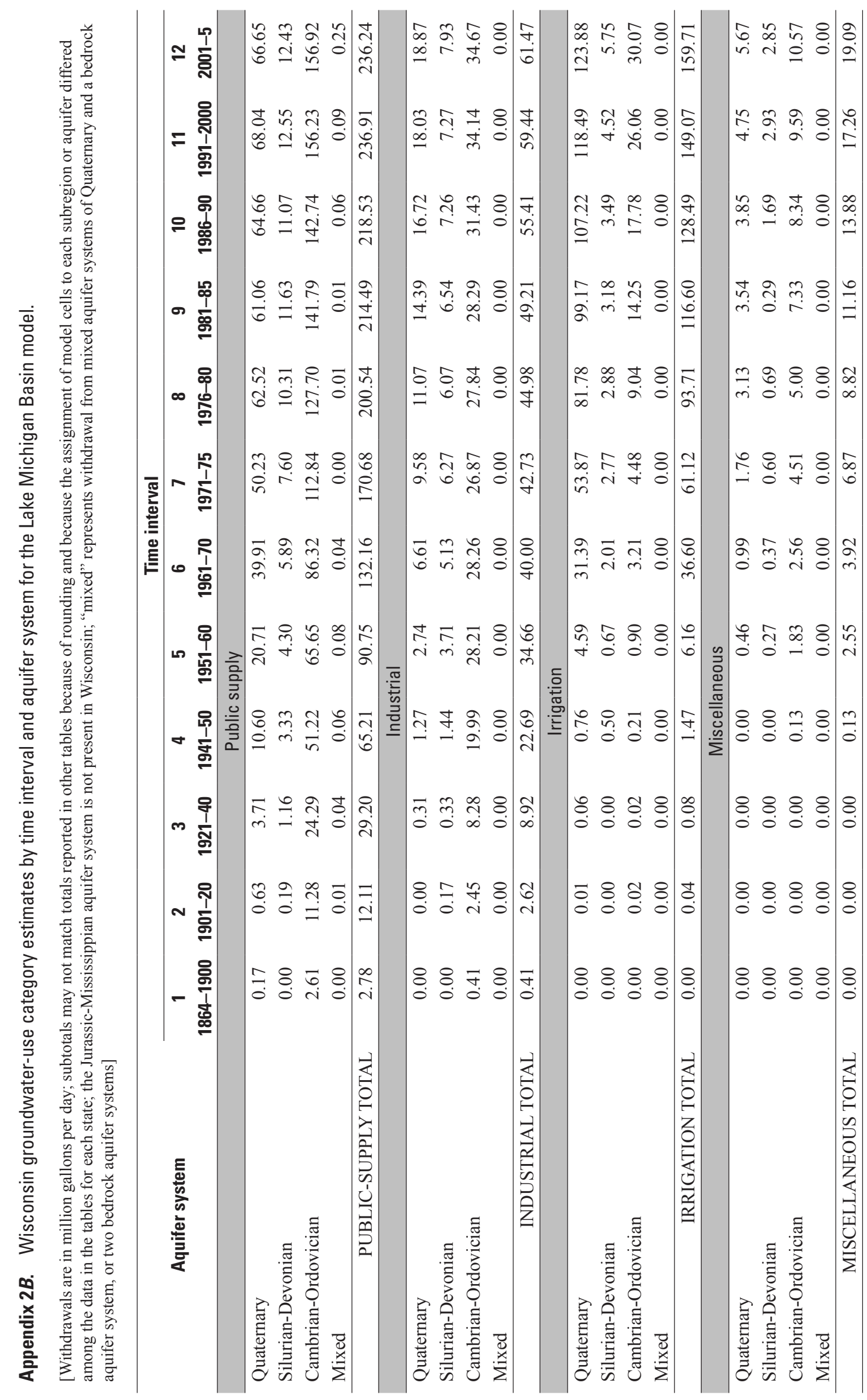




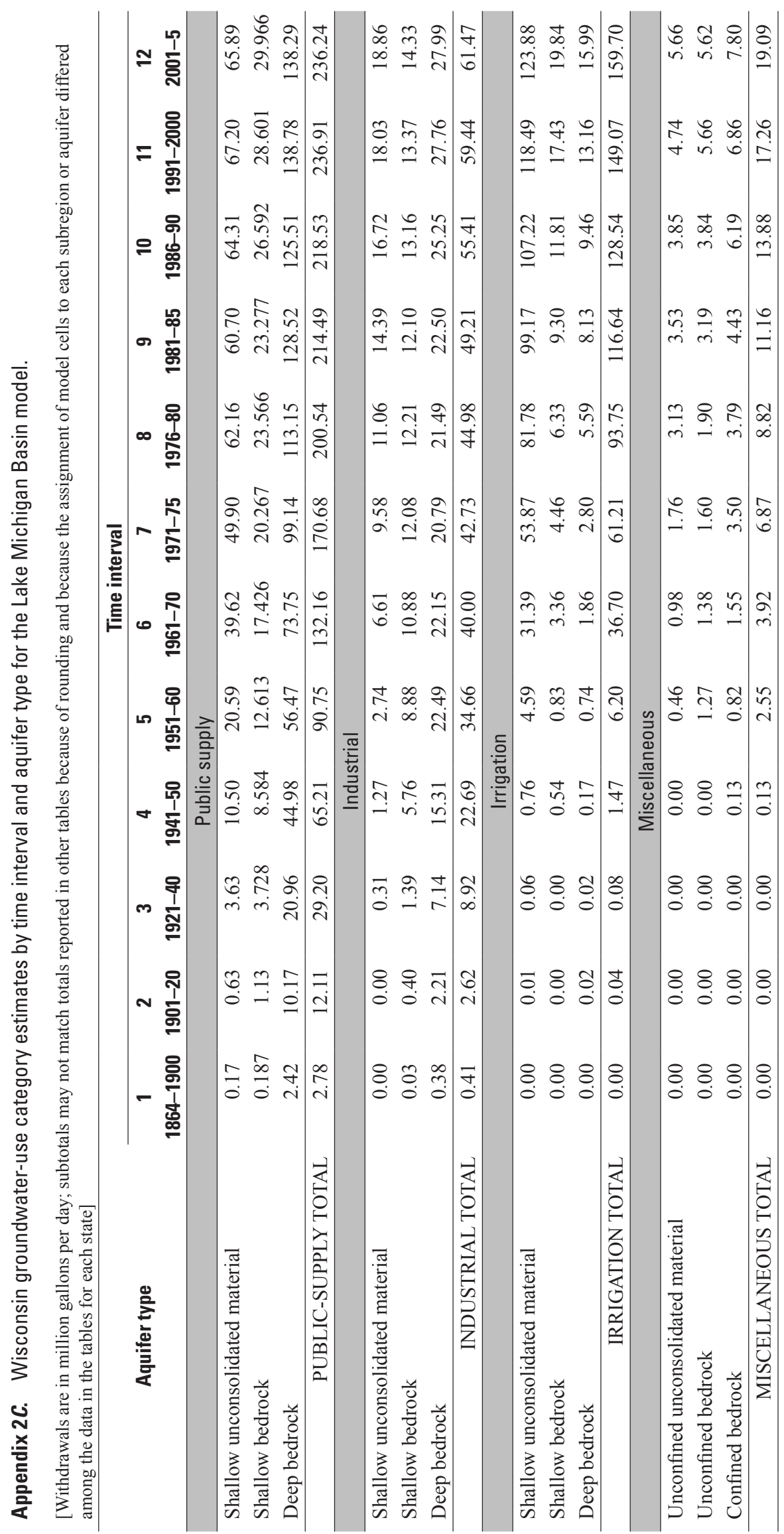




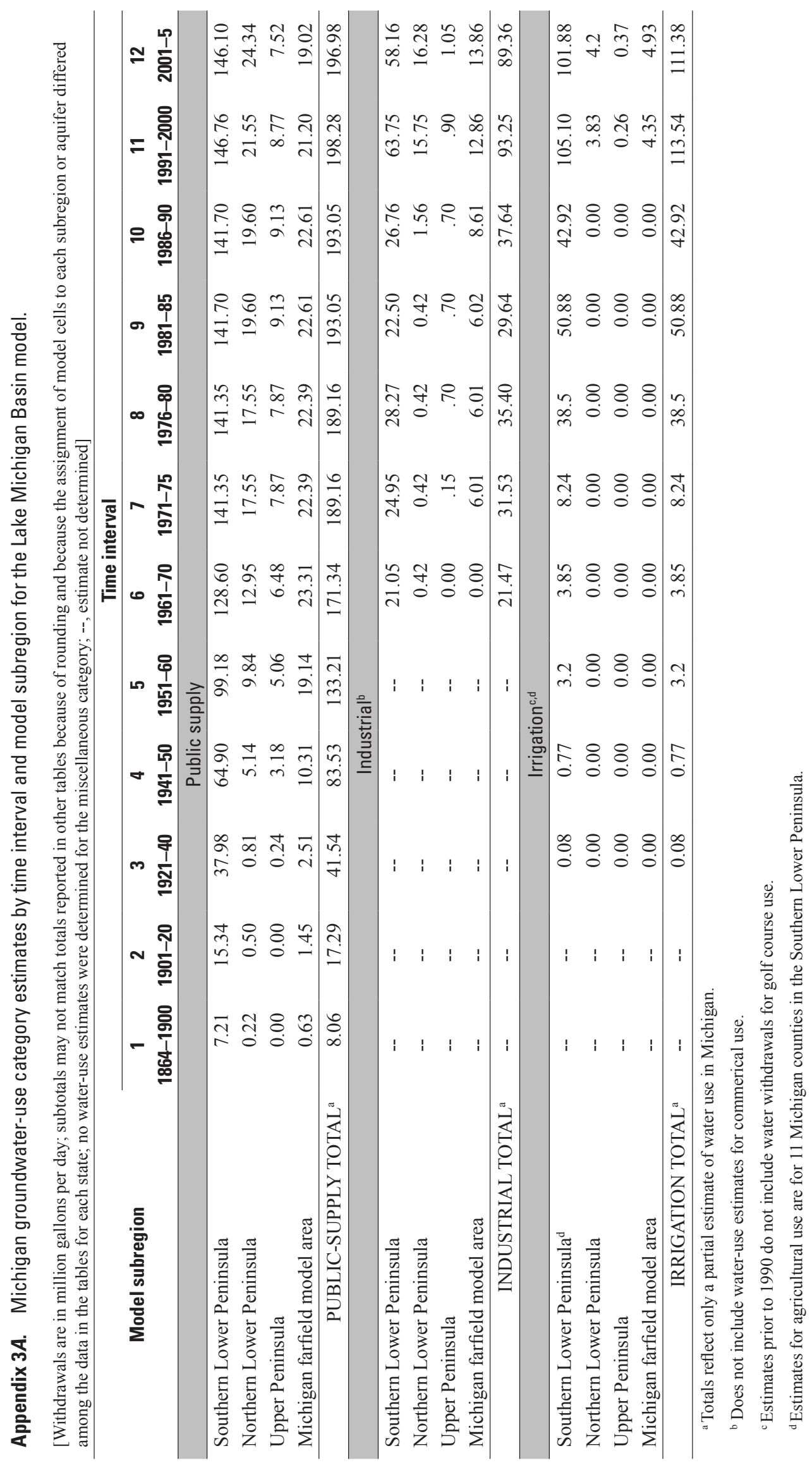




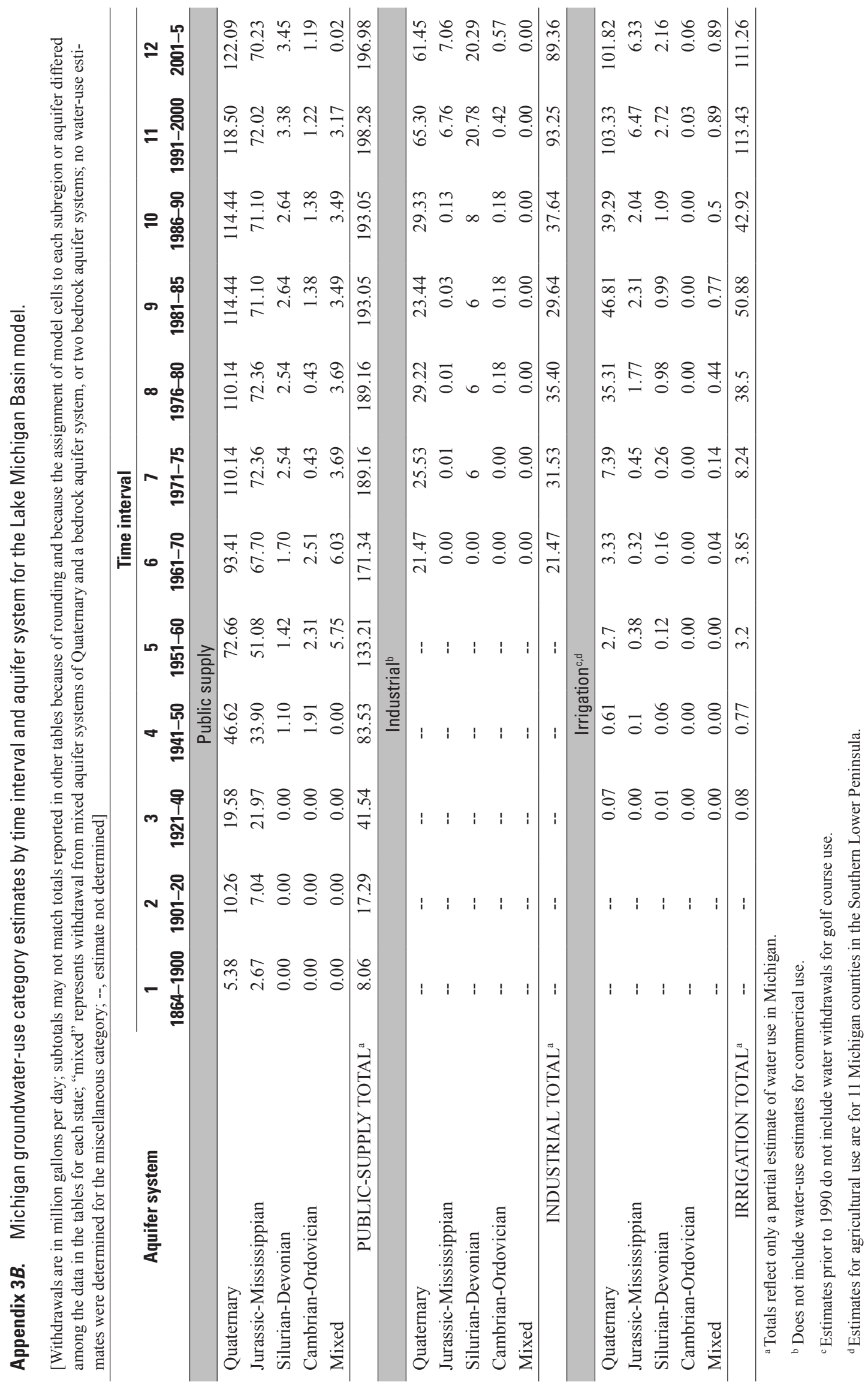




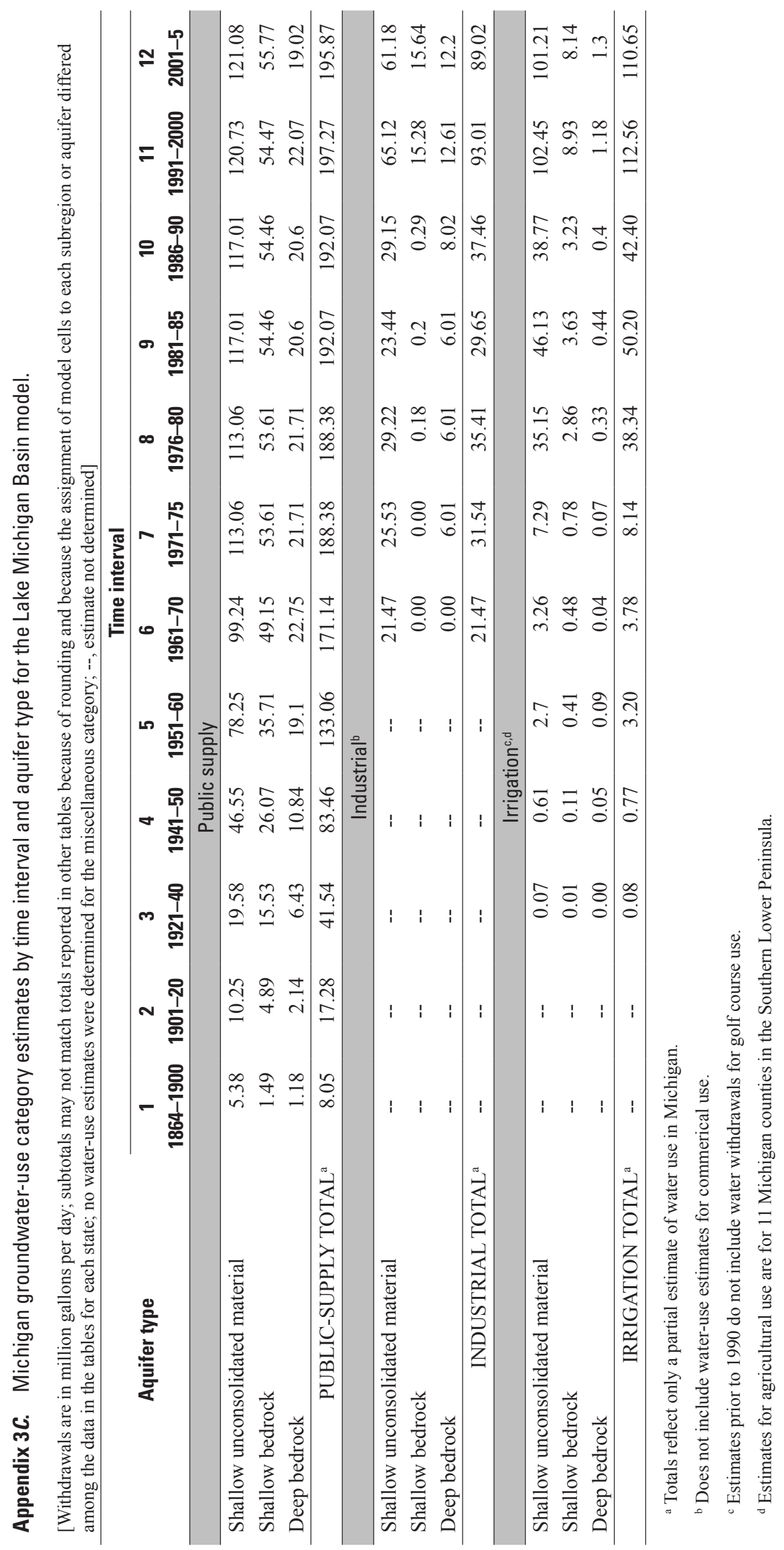




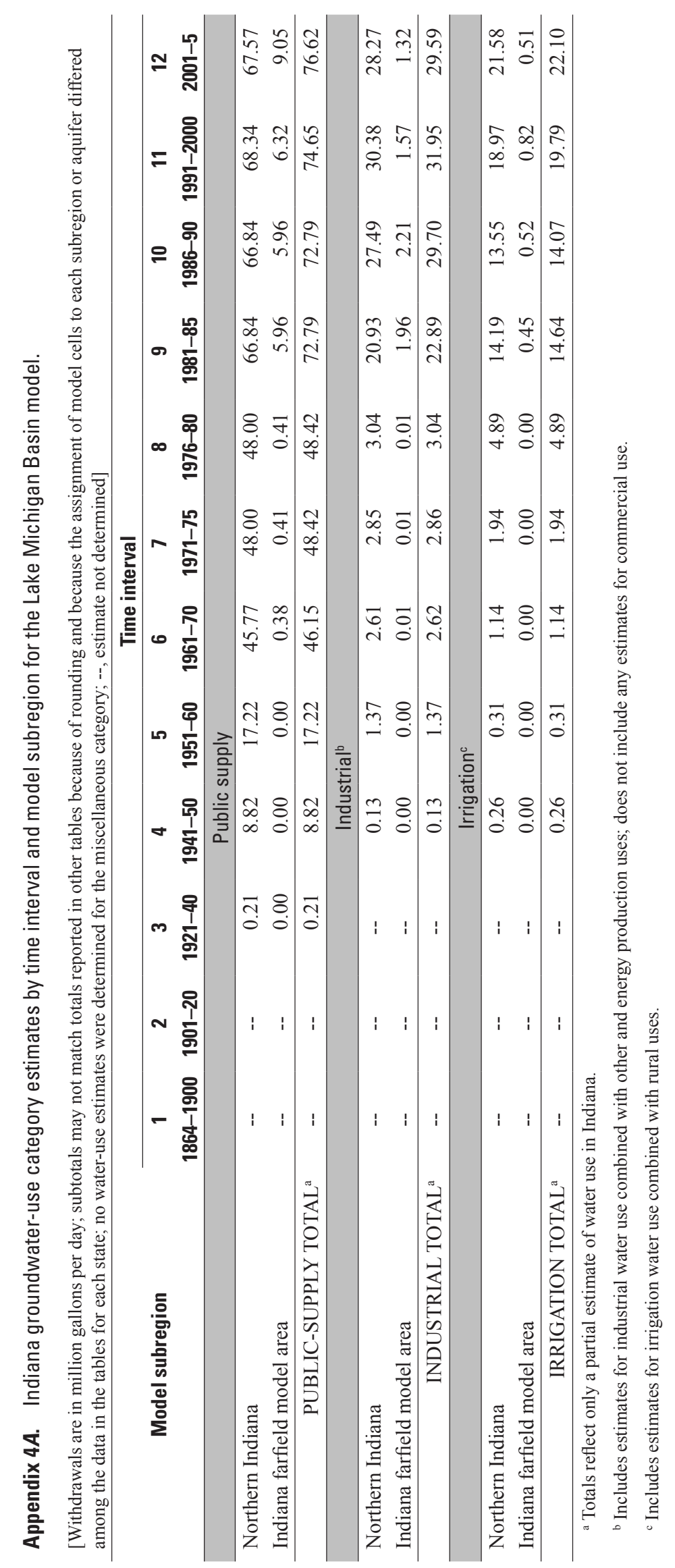




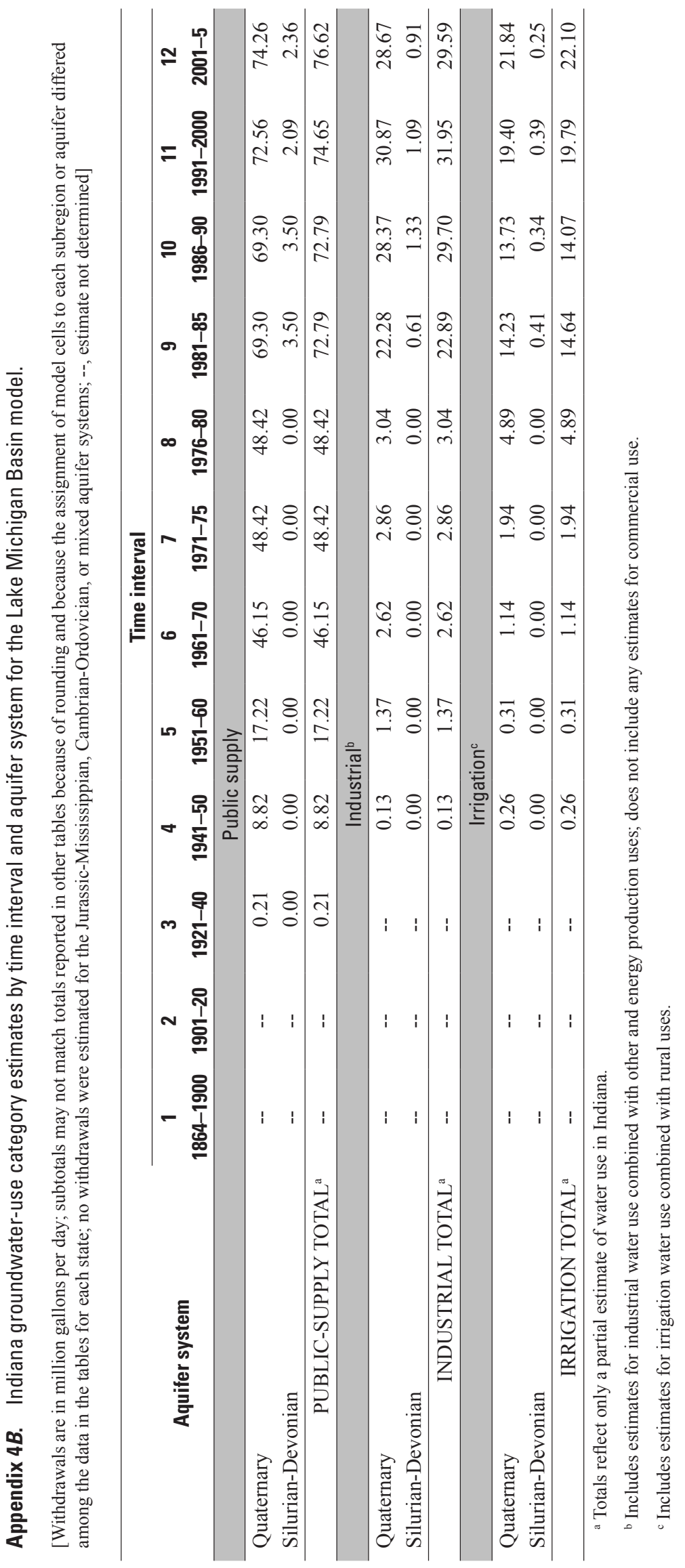














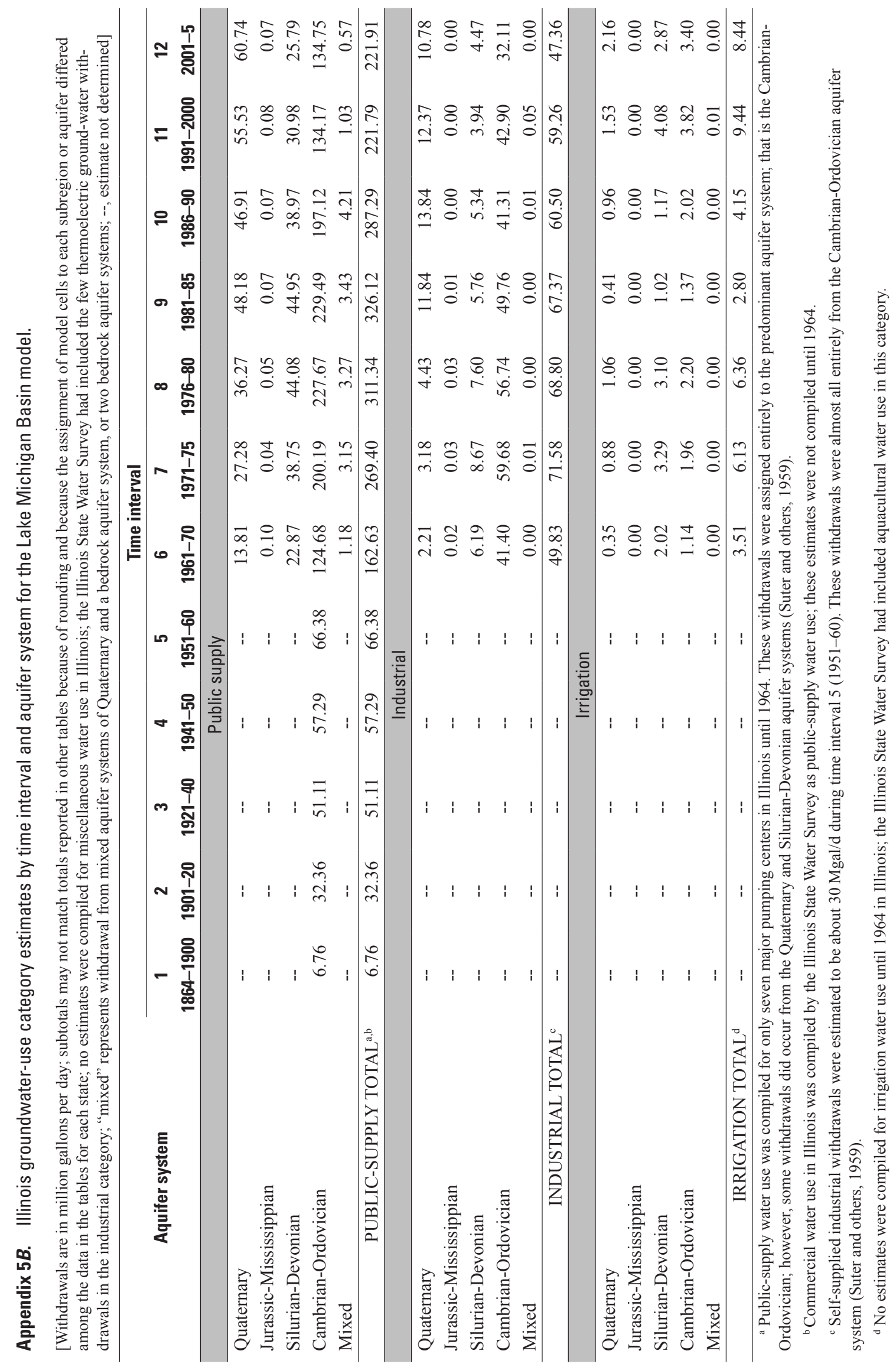




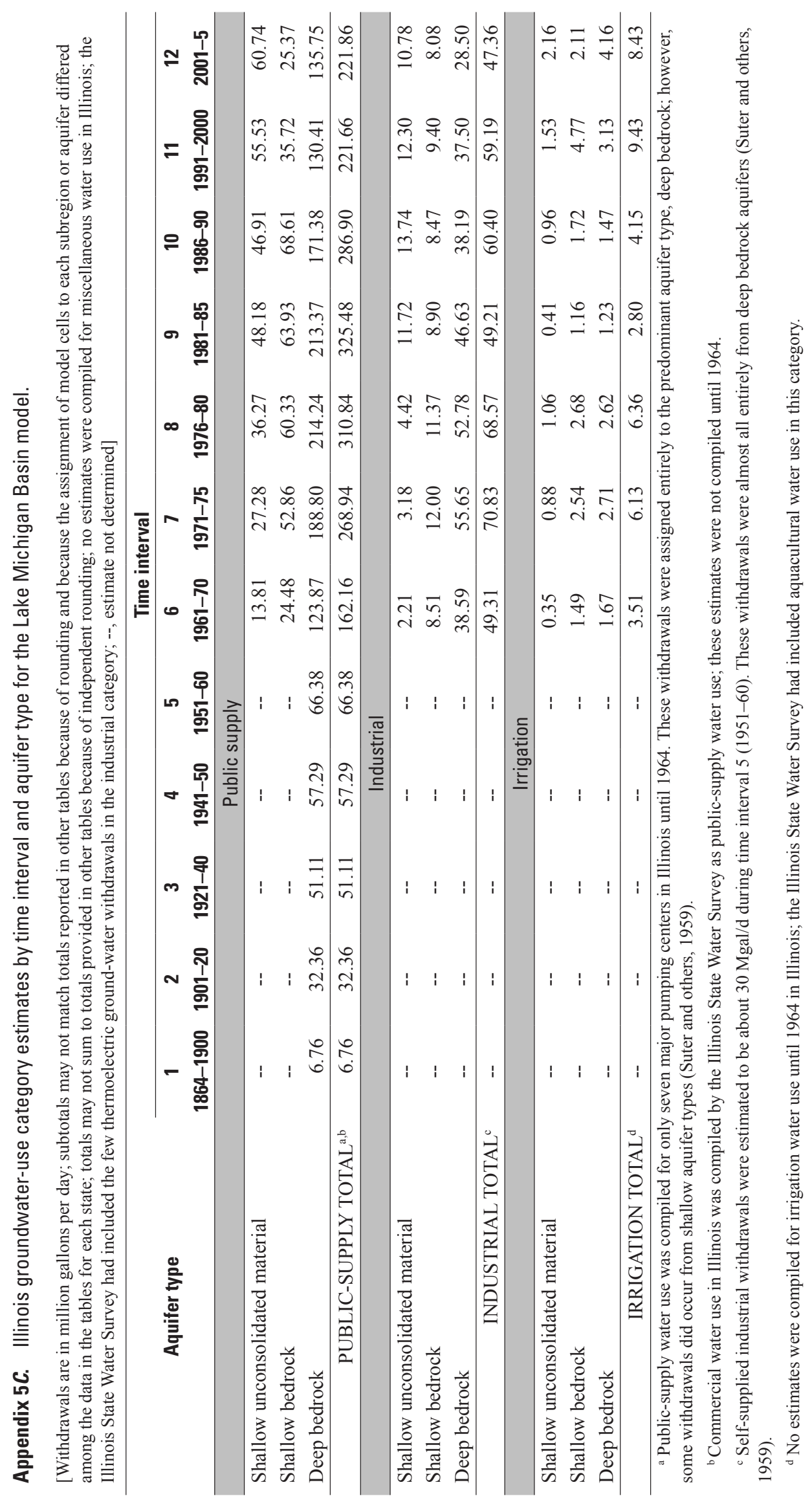




\section{Appendix 6A. Estimation Methods for 2040 Water Use}

In support of the groundwater-flow-model evaluation of the potential effect of future groundwater withdrawals on water availability, water-use estimates were prepared for 2040 for each model subregion by aquifer system and water-use category (appendix 6B). The same water-use categories (public supply, industrial, irrigation, and miscellaneous) defined for the initial 12 model time intervals from 1864 through 2005 were used without any changes to the category definitions. (See table 1 in main part of report.)

Estimates of water use rely on understanding the factors that influence water demand (Thompson, 1998; Horn, 2007). Water-use changes can be attributed to population growth and to climatic, economic, and social changes (Hutson and others, 2004). These projections are based on population projections, land-use changes, projected employment information, waterapplication rates, irrigated farms and acreage, available waterwithdrawal data, and previous projections and were developed according to the methods outlined in appendix $6 C$. Projections in this appendix are based on a set of expected changes in the future and may vary significantly from actual 2040 water withdrawals, depending on such factors as future water-resources or irrigation practices, population changes, legislation, conservation practices, new industries, and climate changes (see the Limitations section in this appendix).

Population projections were used in the estimates of future public-supply water use. Land-use projections for 2040 were assessed to determine the types of development expected in the Lake Michigan Basin model (hereafter referred to as "LMB model") area. Most growth is projected to be outwards from community centers and along transportation corridors (Purdue University, 2008). These projected future growth areas, along with projected employment information, were used as a guide in the estimation of industrial water use. Although an important controlling factor in water use, climatic variables were not considered in the estimates of future irrigation water use because of the many uncertainties with predicting future climate. However, withdrawals for agricultural irrigation in the LMB model area have been relatively constant (as described in a U.S. Department of Agriculture publication for the North Central region for 1969 through 1998) as a result of greater efficiencies in water management and irrigationsystem technology (Heimlich, 2003), even though irrigated acreage has increased. Water-application rates, water-use trends, and projections of irrigated acreage or land use were used in the estimation of irrigation water use.

Projected water use for 2040 for each model subregion was estimated by summing county water-use estimates in each respective subregion. County water-use estimates were developed by using data from various sources in combination with the methods tabulated in appendixes $6 C$ and $6 D$ and described below. In Wisconsin and Michigan, a few counties straddle subregion boundaries. If generally a third or more of a county was within one subregion and the rest in another, then the total estimated water use for the county was divided among the subregions on the basis of the area within each subregion. If approximately a quarter or less of a county was within a subregion, then the total county estimate was assigned to the subregion that contained the majority of the county.

Distribution of these estimates between aquifer systems was based on the distribution percentage from interval 12 (2001-5), the last model time interval for each subregion. The only modification to this method for determining the aquifersystem distributions was for a few counties in Wisconsin (Brown, Calumet, Door, Kenosha, Racine, Walworth, and Waukesha Counties), because some public-supply utilities are or will be switching water sources (groundwater to surface water) or aquifer sources (bedrock to glacial). These shifts were identified from correspondence or trends in recently constructed and abandoned public-supply wells and are discussed in the Public Supply section.

\section{Public Supply}

The general approach for estimating 2040 public-supply water use in the Wisconsin, Michigan, and Indiana LMB model areas relied on projected population and per capita use rates (appendix $6 C$ ). Specifically, to determine these estimates, the projected 2040 population being served groundwater by a public water-supply system was multiplied by an estimated groundwater per capita use rate. In the Illinois LMB model area, 2040 public-supply groundwater use was estimated by Southern Illinois University Carbondale (Southern Illinois University Carbondale, 2005; Dziegielewski and Chowdhury, 2008).

For Wisconsin, Michigan, and Indiana, estimated publicsupply data for 2005 - including population served, total groundwater withdrawn, and per capita use - were assembled. The estimated 2005 public-supply per capita use for each county in Wisconsin, Michigan, and Indiana was assigned for 2040 except for five counties in Wisconsin (Kenosha, Portage, Racine, Sauk, and Waupaca Counties) where public-supply groundwater per capita use was greater than 200 gal/d per person. For these counties, the per capita use was reduced by 15 percent on the basis of southeastern Wisconsin projections for 2035 of reductions in maximum daily demands from 6 to 18 percent (Southeastern Wisconsin Regional Planning Commission, 2009). This reduction reflects both supply-side efficiency and demand-side conservation measures and accounts for possible future conservation initiatives or increased domestic and commercial uses in replace of typically larger industrial uses.

Projected populations for 2040 were determined from available data as follows for each State (appendixes $6 C$ and $6 D$ ). In general, an estimate of the population in 2040 was determined from the average percentage change in population over the available years of data.

For Wisconsin, total county populations listed by community were collected from the Wisconsin Department of Administration (WI DOA) (2009) for the census year 2000 and 
other available years with projected population through 2030 . Estimates of the population in 2040 for Wisconsin communities were based on half of the calculated annual 30-year growth rate because WI DOA future population projections tend to be slightly overestimated and have not been adjusted at this time (2009) for the future pattern of births and deaths (David EganRobertson, Wisconsin Department of Administration, written commun., 2009). Five exceptions of community populations were projected with a different method because additional information was available to supplement the WI DOA projected populations. The City of Milwaukee, Milwaukee County, had an annual loss of 8.9 percent. Rather than continue with this rate of decline, the 2025 WI DOA population projection estimate was substituted. For four other communities (Town of Greenville, Outagamie County; Towns of Lawrence and Ledgeview, Brown County; and the Town of Harrison, Calumet County), the 2030 population projection estimate was substituted because population growth is expected to decline in response to downtrends in the areas' economies (Lisa Beyer, Greenville Water \& Sewer Department, oral commun., 2009).

For Michigan and Indiana, county populations were compiled from census reports (U.S. Bureau of the Census, 2009) and other years with available projected populations (appendix $6 D$ ). In Michigan, some county population projections were available to 2035 from the state planning and development regions; but in general, most counties could furnish projections only to 2020 (Tri-County Regional Planning Commission, 1992, 2008; Northeast Michigan Council of Governments, 2006; Tim Anderson, Region 2 Planning Commission, written commun., 2008; Jeff Hagan, Eastern Upper Peninsula Regional Planning and Development Commission, written commun., 2008; Kathy TenWolde, East Central Michigan Planning and Development Regional Commission, written commun., 2009; West Michigan Shoreline Regional Development Commission, 2009). Some areas of Michigan are not experiencing much growth or are expected to have declining populations (Kathy TenWolde, East Central Michigan Planning and Development Regional Commission, and Richard Deuell, Northeast Michigan Council of Governments, written commun., 2008). In Indiana, county population projections were available to 2025 (Indiana Business Research Center-Indiana Department of Workforce Development, 2009). Estimates of the 2040 projected population in Michigan and Indiana counties were based on the average of the trends for each 10-year interval from 1970 to 2000 applied to the projected 2020 values. County population projections to 2040 for Indiana were discovered after estimates were completed (Indiana Business Research Center-Indiana University's Kelley School of Business, 2009). These 2040 population projections for counties within the Indiana LMB model area were within 1 percent of the values estimated for this study by using the method described in appendix $6 C$.

Population served groundwater by public water-supply systems for each subregion was determined for Wisconsin at the community level by summarizing 2040 community population-served estimates. In most cases, 100 percent of the 2040 population for a community was assumed to be served by public supply; but if a community was partially served by public supply in 2005 (Buchwald, 2009), then the same percentage of the community population from 2005 was used to calculate the 2040 community population-served groundwater estimate. For communities in Wisconsin without a public water-supply system in 2005 that are expected to grow by more than 40 percent, it was assumed that the community could develop a public water-supply system. In these communities, half of the 2040 community population estimate was assumed to be served by public supply. The other communities without a public water-supply system and not expected to grow by more than 40 percent were assumed to remain self-supplied.

Communities in Wisconsin that have switched since the last model time interval (2001-5) from groundwater to surface water as a source for public supply were identified (Central Brown County Water Authority, 2007; City of Green Bay, 2009). Additionally, several calls were placed to community water utilities in Wisconsin to identify public water-supply systems that were considering or planning a change in water source from groundwater to surface water. The associated populations served by groundwater during the last model time interval (interval 12, 2001-5) but determined most likely to be served surface water by 2040 were removed from the 2040 county estimate for population being served groundwater. Also available were public-supply water-use projections for 2035, by community, from a study within the Southeastern Wisconsin subregion (Southeastern Wisconsin Regional Planning Commission, 2008b). The estimates produced in this study by community and summarized by county were within the projected range of future groundwater withdrawals produced by Southeastern Wisconsin Regional Planning Commission (SEWRPC) except for Waukesha County; there, it was assumed that a few additional communities not listed by SEWRPC have the possibility for expanding their existing surface-water supply system or converting, at least partially, to surface water as a source for public supply. Additionally, this study helped identify communities with a public supply that is planning to change from one aquifer system to some other, or at least incorporate some portion of its supply from a previously unused aquifer system.

In Michigan and Indiana, the percentage of the county population relying on groundwater from a public water-supply system for 2040 was estimated on the basis of the most recent data available. Because the population served by groundwater from a public water-supply system was not reported in 2000 or 2005, this percentage was determined from 1998 data for Michigan (Ron Van Til, Michigan Department of Environmental Quality, written commun., 2002) and from 1995 data for Indiana (U.S. Geological Survey, 2009). The more detailed approach of using community-level population estimates was needed to capture some of the water-source shifts that were expected for particular counties of Wisconsin that were unlike those in Michigan and Indiana. Overall, most county-level populations relying on groundwater from a public water-supply system for 2040 were assumed to be similar to the percentage of those populations served during 2005. 


\section{Industrial}

Approaches for estimating 2040 industrial water use differed in the LMB model areas because of the types of data available (appendixes $6 C$ and $6 D$ ). However, employment projections were considered in each state as an indication of the amounts of water that might be used in the future. In general, industrial water use in 2040 was estimated for Wisconsin by adjusting regional estimates for model time interval 12 (2001-5) with projected percentage change in employment. For Michigan and Indiana, industrial water use in 2040 was estimated by using the average change in reported withdrawals as described below. Illinois industrial groundwater use estimates for 2040 were used directly from Dziegielewski and Chowdhury (2008) or were determined by one of two methods described further below.

Regional employment projection data for 2016 were obtained from the Wisconsin Department of Workforce Development (2009) and assigned to the model subregion that the employment region predominantly described. The employment regions of Wisconsin were assigned to the model subregions as follows: Bay Area and Fox Valley to Northeastern Wisconsin subregion; Milwaukee/Washington, Ozaukee, and Waukesha (WOW) Counties and Southeast Wisconsin to Southeastern Wisconsin subregion; and North Central, South Central, and Southwest to the farfield Wisconsin model area. Additional regional employment forecasts for Southeastern Wisconsin were obtained for 2010 through 2035 but were used only as reference to the method developed for the entire Wisconsin model area (Southeastern Wisconsin Regional Planning Commission, 2004).

Regional employment forecasts for 2014 were obtained from the Michigan Department of Energy, Labor, and Economic Growth (2004) for various metropolitan areas or regions throughout Michigan; employment forecasts for 2014 were assigned to the county or counties within the appropriate region or metropolitan area.

Long-range employment projections for 2012-29 for the State of Indiana were obtained from the Indiana University Center for Econometric Model Research at the Kelley School of Business (2009).

Employment data such as employment and labor productivity growth rates were obtained from various sources, including the U.S. Bureau of Labor Statistics (2009) and the Illinois Department of Employment Security (2009). These data were not incorporated into the industrial water-use estimates for Illinois but served only for comparison of the direction and magnitude of the estimates.

Part of the Wisconsin industrial water-use category for this model water-use dataset contained commercial water use; therefore, both industrial and commercial water use and employment projections were considered. The Department of Workforce Development definition of "industry," in general, means the type of employment field and therefore includes commercial businesses, much as the industrial water-use category may contain some commercial water uses in this report. The employment-projection data for employment types of construction/mining/natural resources and various forms of manufacturing were grouped as industrial employment, whereas employment-projection data for all other employment types (such as trade, education and health services, leisure and hospitality) were considered commercial employment. Of these two groupings, the 10-year average percentage change for industrial and commercial employment types was calculated, and it was then assumed that the same 10-year trends in the employment rates would continue until 2040. These changes in employment rates are summarized by model subregion in appendix $6 E$ and were used to adjust the model-defined industrial water-use category (table 1).

Alternatively, public-supply delivery data categorized for industrial and commercial uses by county in Wisconsin and stored in the USGS AWUDS database for 1985, 1990, 1995, 2005 were analyzed (data for 2000 were not collected). The change between the 2005 and 20-year average for both commercial and industrial uses was considered. In most cases, the changing rate could be projected forward with the assumption that the observed trend in public-supply delivery would be similar to the growth rate of self-supplied withdrawals. However, rates in some counties changed considerably over the last two time intervals and required review on a case-bycase basis. Therefore, a more regional approach was used that could be based on a broad trend. Also, employment data cannot directly be applied as a coefficient to withdrawals during the last time interval because no clear relationship can be shown without further statistical analysis. However, inspection of the rates of employment changes does indicate the likely direction of industry and gives some insight into potential water-use trends.

In Michigan and Indiana, public-supply delivery data are largely estimated and often derived by different methods for different summary years; therefore, these data could not be reliably used to determine the projected trend in rate of change in industrial withdrawals. Instead, existing withdrawal information was used to determine the expected rate of change for industrial withdrawals. In Michigan, the rate of change was determined from reported data for 1997-2004 (Michigan Department of Environmental Quality, 2009). Projected water use for 2040 in Michigan was reduced in the Southern Lower Peninsula subregion because of some reductions in water use by industry in Kalamazoo County just after the last LMB model time interval (2001-5). Michigan water use determined from groundwater-withdrawal trends differed by less than 1 percent from estimates determined by using employment forecasts without any reductions in expected water use in Kalamazoo County and by about 12 percent with the same reduction in use in Kalamazoo County applied to the estimates determined by using employment forecasts.

In Indiana, the rate of change was determined from reported data for 1995-2000 (U.S. Geological Survey, 2009). Indiana water use determined from groundwater-withdrawal trends indicated a larger increase than has been projected on the basis of industry forecasts for 2012-29; however, estimated 2040 withdrawals are lower than estimated withdrawals 
for industry in 1990 and 1995. Projected trends in employment and gross state product variables for Indiana generally indicate low growth; however, some metropolitan areas show stronger employment growth. Thus, the estimates for 2040 water use estimated for this study for Indiana are based on the assumption that economic conditions in the area will improve; however, these estimates may be overly optimistic and may overestimate actual water use.

Illinois 2040 industrial groundwater-use values were determined by using one of three methods:

1. use the estimates directly from Dziegielewski and Chowdhury (2008);

2. adjust, if needed, baseline estimates prepared by the Southern Illinois University Carbondale (2005), calculate the annual change in water use (2000-25), and project to 2040 using same rate; or

3. calculate the annual change in groundwater use (19952000) reported by the USGS (U.S. Geological Survey, 2009) and project to 2040 by using the same rate.

In the nearfield model area of Illinois, the 2040 industrial groundwater use under a current-trend scenario was estimated by Dziegielewski and Chowdhury (2008). In the farfield model area of Illinois, the combined surface-water and groundwateruse baseline estimates for 2025 industrial use (Southern Illinois University Carbondale, 2005) were corrected to account for groundwater use only. This correction was based on the percent contribution by water source from USGS data for the year 2000 (U.S. Geological Survey, 2009). If the county was not identified by the USGS as using surface water for industrial withdrawals, then no adjustment was applied. The annual change in water use (2000-25) was calculated and projected to 2040. Method three was used to estimate water use in Bureau County. The Southern Illinois University Carbondale 2025 baseline water-use estimate of $8.152 \mathrm{Mgal} / \mathrm{d}$ was assumed to be incorrect because the withdrawal for 2000 appears to be too high. (The university report uses an historical estimate for 2000 of $5.239 \mathrm{Mgal} / \mathrm{d}$ that is 175 percent greater than industrial use $(0.03 \mathrm{Mgal} / \mathrm{d})$ and almost twice public supply use (2.90 Mgal/d) reported for 2000 by USGS.)

All counties in Wisconsin vary annually in the amount of groundwater withdrawn, but certain counties were known to have more recent changes; an example is Milwaukee County, where the last industry withdrawing groundwater closed during the last LMB model time interval (2001-5). Therefore, 2007 groundwater withdrawals reported to the WDNR were retrieved and evaluated for 12 counties: 5 counties in the Northeastern Wisconsin subregion closest to Green Bay and Lake Winnebago, 5 other counties in the Southeastern Wisconsin subregion, and 2 counties in the farfield model area with the largest withdrawal amounts. The status of an existing well in the model water-use database was updated if there were changes and if new wells not previously identified were added at the 2007 withdrawal rate (Wisconsin Department of Natural Resources, 2009). Ultimately, a new base water-use estimate by subregion was determined to adjust withdrawal amounts for the last time interval closer to 2007 actual withdrawals (appendix 6E).

\section{Irrigation}

Approaches for estimating 2040 irrigation water use differed for all states in the LMB model area because of the types of data available (appendixes $6 C$ and $6 D$ ). In Wisconsin, water-application rates, based on total amounts of water withdrawn, determined during the development of water-use estimates for the LMB model were applied to projected irrigated acreage for an estimate of 2040 water use. In Michigan, irrigation water-use estimates for agriculture and golf courses were developed separately. The average percentage change in irrigated land acreage was applied to the agricultural irrigation withdrawal amount from the last time interval of the LMB model. Previously collected data on groundwater withdrawals for golf course irrigation were used for the estimate of 2040 water use. In Indiana, the average percentage change in the number of farms with irrigated cropland was applied to the withdrawal amount from the last time interval of the LMB model. In Illinois, 2040 irrigation groundwater use was estimated in part by Dziegielewski and Chowdhury (2008) for the Northeastern Illinois subregion and in part by extending current water-application rates to estimated future irrigated acreage for the Illinois farfield model area.

In Wisconsin, an irrigation water-use estimate for 2040 was determined for each county by using a base value for irrigation acreage multiplied by a water-application rate. The base irrigation acreage was determined as described in appendix $6 C$. This base value was then adjusted for anticipated percentage change of land for agricultural crop production. This rate of projected land-use change was derived from output geographic information system grids from the Land Transformation Model (Purdue University, 2009). Land-use type projections for 2000 and 2030 were developed by using the Land Transformation Model data. The annual rate of change was calculated for the 30-year time span and applied directly to estimate percentage change for the year 2040. Land acreage irrigated for crops in the LMB model was determined from land use coded as agricultural row crops in the Land Transformation Model. Generally less land use is expected in the future for agricultural row crops, based on Land Transformation Model estimates. Overall, agricultural production land use in the Wisconsin LMB model area was projected to decrease by about 6.5 percent or 18,198 irrigated acres, from a total irrigated acreage of 280,660 acres in time interval 12 (2001-5) to 262,462 acres in 2040 . No change in land for golf courses was expected in the Land Transformation Model; therefore, no adjustment for golf course water use was made.

In Michigan and Indiana, an irrigation water-use estimate for 2040 was determined for each county from the average change in reported data multiplied by current waterwithdrawal amount. Data were compiled on number of farms, irrigated acreage, and reported withdrawals (National 
Agricultural Statistics Service, 1992; U.S. Department of Agriculture, 1992, 1994, 1997, 2002, and 2007). Additional data were available in Michigan on the number of golf courses (Michigan Department of Environmental Quality, 2009). Agricultural data for Michigan indicated the tendency towards fewer farms with larger acreages; specifically, a trend toward increased irrigated acreage over time coincident with decreased total acreage of cropland over time. Trends in number of farms or golf courses, irrigated acreage, and groundwater withdrawals, along with the potential impact of these trends on estimated water use in 2040, were examined. In Michigan, 2040 estimates determined by using the trend in irrigated acreage during 2002-7 indicated low to moderate growth, which is believed to be the most representative of potential water use in 2040 .

For Indiana, trends in number of farms, irrigated acreage, and groundwater withdrawals were examined, along with the potential impact of these trends on estimated water use in 2040. In Indiana, 2040 estimates determined by using the trend in number of farms with irrigated cropland during 1978-2002 also indicated low to moderate growth, which is believed to be the most representative of potential water use in 2040. This estimate for Indiana was similar to the estimate determined by using groundwater withdrawal trends for 1987-2002 and was slightly higher than the estimate determined by using the trend in irrigated land.

In Illinois, groundwater-use estimates in the Northeastern Illinois subregion reported by Dziegielewski and Chowdhury (2008) for 2040 were summed by county for cropland irrigation and golf course irrigation and directly applied as the 2040 groundwater-use estimates (appendix $6 B$ ). However, irrigation water use in farfield model area was estimated rather than adopted directly from available projected withdrawals for 2025 (Southern Illinois University Carbondale, 2005) because the projections included surface-water use and were 15 years short of the future target year of 2040. For the 18 counties within the farfield model area, irrigation water use was determined by using the average groundwater-application rate of 0.6 acre-foot per year per acre (or $535.6 \mathrm{gal} / \mathrm{d} / \mathrm{acre}$ ) based on data from an irrigation survey for 2003 (U.S. Department of Agriculture, 2004b) and projected irrigated acreage, with the exception of Winnebago County; there, the approximated application rate was twice as much, at 1.12 acre-foot per year per acre (or 1,000 gal/d/acre). The projected irrigated acreage for 2040 was based on evaluating the current trend (similar to how Wisconsin irrigated acreage was estimated) to create a base amount used for the last time interval multiplied by the county's expected population growth rate between 2000 and 2040 (Department of Commerce and Economic Opportunity, 2009). Typically, population growth is not commonly used as an indicator for predicting future irrigation water use; rather, variables such as climate, economics, crop and soil characteristics, and irrigation practices are used. However, after an evaluation of Census of Agriculture and USGS water-use data, it was discovered that some county irrigation water-use estimates in the Illinois farfield model area were underrepresented in the model. Total groundwater use for irrigation in 2000 summarized for the farfield counties was reported by the USGS at $37.76 \mathrm{Mgal} / \mathrm{d}$ (U.S. Geological Survey, 2009), which includes some water use for six counties that are outside the study extent; in contrast, the model water-use dataset from the ISWS accounted for $2.93 \mathrm{Mgal} / \mathrm{d}$ (appendix $5 A$ ). By using the population growth rates as a corrective factor, the estimates that were produced were reasonably similar to withdrawals examined in the Southern Illinois University Carbondale report (appendix 6D). The model estimate for 2040 is 87.08 $\mathrm{Mgal} / \mathrm{d}$, whereas the report estimate for 2025 is $75.07 \mathrm{Mgal} / \mathrm{d}$; however, the latter includes some surface-water use. Therefore, the total irrigation groundwater-use estimate for 2040 in the LMB farfield model area (appendix $6 B$ ) contained a larger contributing amount of withdrawal from the Illinois farfield model area. Because of how these Illinois farfield estimates were created, the authors suggest they not be used at the county level without comparing to values from other available data sources, some of which are described in appendix $6 D$.

\section{Miscellaneous}

Miscellaneous water-use estimates for 2040 were determined for Wisconsin. No estimates of miscellaneous water use were determined for the model areas of Michigan, Indiana, and Illinois because these water uses were either combined into other categories in the initial water use datasets (table 1) or were presumed to be negligible. For the most part, miscellaneous water use for Wisconsin was estimated by taking the average rate of change over the last 20 years in the model simulation (time intervals 10 through 12, 1986-2005) for each model subregion and then directly applying that rate forward to 2040 (appendix 6C). However, because Wisconsin's fish farms are expected to grow in order to meet future product demand (Wisconsin State Roundup, 1998), a small but additional amount of miscellaneous water use was added to the main estimation method described above. It was assumed that aquaculture operators will expand existing facilities rather than establish new sites; therefore, it was estimated that one new water well would be developed per decade per subregion at any existing aquacultural facility. A groundwater withdrawal value of $0.0264 \mathrm{Mgal} / \mathrm{d}$ was assigned to these new facilities on the basis of median water withdrawal in Wisconsin for 2005 (Buchwald, 2009). The total for the subregion was then distributed between the aquifer-system types on the basis of distribution of the last time interval (interval 12, 2001-5).

\section{Limitations}

In general, the methods used to estimate 2040 water use by category for each state were based on data that were commonly available for each state so that methods would be consistent. However, in some cases, different approaches were used because of the types of data that were available. 
The authors acknowledge that many factors locally and regionally affect water demand, and many of these factors are not accounted for in the 2040 water-use estimates developed for this study for use in the LMB model. Communities may expand water-supply service areas, respond to changing water rates, attract new large-scale developments or waterintensive industries, or institute water-conservation measures in response to water-availability constraints or community goals. Likewise, in response to water-availability constraints, farmers may change crops or agricultural practices, utilities may implement a new automatic meter-reading program or advanced metering infrastructure, and industries may begin or increase their practice of reusing or reclaiming process water. Changes in technology could permit increased use of groundwater for irrigation or industry or could permit decreased use of groundwater because of more efficient practices. Climatic fluctuations also affect water use, but these effects are difficult to isolate and predict (Hutson and others, 2004). Therefore, these estimates of future water use likely have high uncertainties because all of the climatic, social, economic, and political or policy variables that potentially influence water demand were not taken into account in the development of these estimates.

Public-supply estimates were calculated on a per capita basis. These estimates do not take into account the possibility that conservation measures may be adopted by individual communities. These estimates also do not take into account how deliveries for domestic, industrial, commercial, public, and utility use may change over time. The potential for communities to change water sources or create service areas was accounted for only on a limited basis in Wisconsin and not at all in Michigan and Indiana because these changes depend on many factors and are difficult to predict, which was beyond the scope of this project. The percentage of each county population relying on groundwater in 2040, and the distribution of withdrawals from aquifers, may differ from that in 2005. Population projections for each state were estimated by various entities using different methods, so projections may be overestimated or underestimated.

Industrial estimates were calculated on the basis of employment data, land-use changes, and past water-use trends. These estimates also do not take into account possible waterconservation measures by various industries or possible shifts in facility types. Employment projections could not be directly incorporated into the water-use estimates without further statistical analysis. The employment data projected for each area were not reported for specific industries and do not directly relate to withdrawals. Some of these industries likely are publicly supplied or may rely on surface-water sources. And because water usage varies considerably among different types of industries, employment projections for specific industry types would be preferable to use. In addition, economic conditions, which can affect industries and their associated water use, may improve, stay the same, or worsen over time to 2040, thus complicating the estimation of water use because of the uncertainty in predicting these changes.
Irrigation estimates were calculated on the basis of water-use trends, irrigated-acreage or land-use changes, and water-application rates. Although the largest controls on irrigation water use are climate (that is, precipitation, temperature, evapotranspiration), soil type, and crop type (U.S. Department of Agriculture, 1955), the authors assumed that crop type and the application and methods of irrigation would remain unchanged because it is uncertain how climate would change by 2040 and how farmers would react to such changes. Thus, these estimates do not account for potential changes in withdrawal amounts in response to changes in climate. A projected increase in withdrawals in response to drier weather in 2040 may be offset by increased efficiencies (and the need to withdraw less water to irrigate the same crop acreage) or by irrigators supplementing from surface-water sources. Similarly, a projected decrease in water demand due to wetter conditions in 2040 may be offset by more irrigators relying on groundwater sources, therefore resulting in higher withdrawal rates than would have been predicted solely on the basis of projected climate changes. So, although irrigation water use varies from year to year in response to changes in climate or other variables, estimation of these future climate variables and inclusion of all potential variables affecting irrigation withdrawal amounts was beyond the scope of this study.

Miscellaneous water-use estimates for 2040 were developed only for the areas of the model that were estimated in the initial water-use dataset, which would be for the subregions of Wisconsin. Any additional miscellaneous water uses that could be identified but were not previously accounted for in the original category definition for a state were excluded to preserve the opportunity to compare totals for each state between past and future estimated use. For each state, additional miscellaneous water uses could have been identified and added, such as for wastewater treatment, mining, remediation, livestock, or self-supplied domestic withdrawals. Additionally, particular types of uses grouped under the chosen model categories (public supply, industrial, or irrigation) possibly could have been filtered and reassigned as miscellaneous water use; however, different methods for estimating future miscellaneous water use for the various types of use would be needed.

Additional information could improve the future estimates. County-level or well-based estimates, for example, could be provided rather than estimates by subregion to improve the future modeling scenario of water availability and to permit more realistic distribution of withdrawals within each subregion. More analysis of different scenarios may be warranted with respect to water price, conservation, climate, and economic changes. Also, categorical ranges of future water use could be estimated instead of single values. These estimates could be improved by verifying withdrawal estimates with reported use or confirming withdrawal amounts with the overseeing state agency. Improvements in record keeping and record availability by the public water-supply systems and other high-capacity water users are underway, so creation of future estimates could greatly improve in response to these updates. 
Appendix 6B. Lake Michigan Basin model time interval 12 (2001-5) and 2040 groundwater-use estimates by category, model subregion, and aquifer system. All subregions listed except for "Farfield model area" are part of the nearfield model area.

[Withdrawals in million gallons per day; "mixed" represents withdrawal from mixed aquifer systems of Quaternary and a bedrock aquifer system, or two bedrock aquifer systems; --, estimate not determined]

\begin{tabular}{|c|c|c|c|c|c|c|c|}
\hline \multirow{3}{*}{ Subregion } & \multicolumn{2}{|c|}{$\begin{array}{c}\text { Total estimated water } \\
\text { use }\end{array}$} & \multicolumn{5}{|c|}{ By aquifer system } \\
\hline & $\begin{array}{l}\text { Average } \\
\text { during } \\
\text { time } \\
\text { interval } 12\end{array}$ & $\begin{array}{l}\text { Estimate } \\
\text { for future }\end{array}$ & Quaternary & $\begin{array}{l}\text { Jurassic- } \\
\text { Mississippian }\end{array}$ & $\begin{array}{l}\text { Silurian- } \\
\text { Devonian }\end{array}$ & $\begin{array}{l}\text { Cambrian- } \\
\text { Ordovician }\end{array}$ & Mixed \\
\hline & $2001-5$ & 2040 & 2040 & 2040 & 2040 & 2040 & 2040 \\
\hline Southeastern Wisconsin & 54.71 & 68.25 & 24.54 & 0.00 & 18.90 & 24.81 & -- \\
\hline Southern Lower Peninsula of Michigan & 146.1 & 183.90 & 101.85 & 82.05 & 0.00 & 0.00 & 0.00 \\
\hline Northern Lower Peninsula of Michigan & 24.34 & 33.66 & 28.56 & 0.00 & 5.10 & 0.00 & 0.00 \\
\hline Upper Peninsula of Michigan & 7.52 & 10.32 & 9.15 & 0.00 & 0.03 & 1.14 & 0.00 \\
\hline Farfield model area & 238.83 & 270.99 & 81.24 & 0.00 & 7.65 & 182.09 & -- \\
\hline PUBLIC-SUPPLY TOTAL & 731.38 & 989.26 & 427.38 & 82.41 & 104.35 & 375.14 & 0.00 \\
\hline \multicolumn{8}{|c|}{ Industrial } \\
\hline Northeastern Wisconsin & 17.05 & 18.32 & 7.97 & 0.00 & 2.93 & 7.41 & -- \\
\hline Southeastern Wisconsin & 11.73 & $3.27^{\mathrm{b}}$ & 0.15 & 0.00 & 0.54 & 2.57 & -- \\
\hline Southern Lower Peninsula of Michigan & 58.16 & $51.94^{\mathrm{c}}$ & 45.78 & 6.16 & 0.00 & 0.00 & 0.00 \\
\hline Northern Lower Peninsula of Michigan & 16.28 & 23.83 & 10.53 & 0.00 & 13.30 & 0.00 & 0.00 \\
\hline Upper Peninsula of Michigan & 1.05 & 1.02 & 0.49 & 0.00 & 0.02 & 0.51 & 0.00 \\
\hline Northern Indiana & 28.27 & 31.42 & 30.40 & -- & 1.02 & -- & -- \\
\hline Southeastern Wisconsin & 6.53 & $5.44^{\mathrm{d}}$ & 1.71 & 0.00 & 1.65 & 2.08 & -- \\
\hline Southern Lower Peninsula of Michigan & 101.88 & 111.54 & 102.24 & 8.33 & 0.97 & 0.00 & 0.00 \\
\hline Northern Lower Peninsula of Michigan & 4.2 & 5.88 & 5.80 & 0.00 & 0.08 & 0.00 & 0.00 \\
\hline Upper Peninsula of Michigan & 0.37 & 0.41 & 0.12 & 0.00 & 0.21 & 0.08 & 0.00 \\
\hline Northern Indiana & 21.58 & 27.17 & 26.74 & -- & 0.43 & -- & -- \\
\hline Northeastern Illinois & 5.51 & $29.15^{\mathrm{e}}$ & 6.36 & 0.53 & 8.04 & 14.22 & -- \\
\hline Farfield model area & 129.18 & 158.82 & 75.81 & 0.00 & 16.09 & 66.92 & -- \\
\hline IRRIGATION TOTAL & 301.61 & 368.37 & 264.80 & 8.86 & 29.28 & 92.59 & 0.00 \\
\hline
\end{tabular}


Appendix 6B. Lake Michigan Basin model time interval 12 (2001-5) and 2040 groundwater-use estimates by category, model subregion, and aquifer system. All subregions listed except for "Farfield model area" are part of the nearfield model area.—Continued

[Withdrawals in million gallons per day; "mixed" represents withdrawal from mixed aquifer systems of Quaternary and a bedrock aquifer system, or two bedrock aquifer systems; --, estimate not determined]

\begin{tabular}{|c|c|c|c|c|c|c|c|}
\hline \multirow{3}{*}{ Subregion } & \multicolumn{2}{|c|}{$\begin{array}{c}\text { Total estimated water } \\
\text { use }\end{array}$} & \multicolumn{5}{|c|}{ By aquifer system } \\
\hline & $\begin{array}{c}\text { Average } \\
\text { during } \\
\text { time } \\
\text { interval } 12\end{array}$ & $\begin{array}{l}\text { Estimate } \\
\text { for future }\end{array}$ & Quaternary & $\begin{array}{c}\text { Jurassic- } \\
\text { Mississippian }\end{array}$ & $\begin{array}{l}\text { Silurian- } \\
\text { Devonian }\end{array}$ & $\begin{array}{l}\text { Cambrian- } \\
\text { Ordovician }\end{array}$ & Mixed \\
\hline & $2001-5$ & 2040 & 2040 & 2040 & 2040 & 2040 & 2040 \\
\hline \multicolumn{8}{|c|}{ Miscellaneous } \\
\hline Northeastern Wisconsin & 12.42 & 18.86 & 9.90 & 0.00 & 6.32 & 2.64 & -- \\
\hline Southeastern Wisconsin & 3.39 & 3.88 & 0.05 & 0.00 & 1.15 & 2.69 & -- \\
\hline Southern Lower Peninsula of Michigan & -- & -- & -- & -- & -- & -- & -- \\
\hline Northern Lower Peninsula of Michigan & -- & -- & -- & -- & -- & -- & -- \\
\hline Upper Peninsula of Michigan & -- & -- & -- & -- & -- & -- & -- \\
\hline Northern Indiana & -- & -- & -- & -- & -- & -- & -- \\
\hline Northeastern Illinois & -- & -- & -- & -- & -- & -- & -- \\
\hline Farfield model area & 3.28 & 5.47 & 1.23 & 0.00 & 0.00 & 4.24 & -- \\
\hline MISCELLANEOUS TOTAL & 19.09 & 28.21 & 11.18 & 0.00 & 7.47 & 9.57 & 0.00 \\
\hline
\end{tabular}

Additional information about these data:

- Values reflect only a partial estimate of water use in Michigan and Indiana.

- 2040 estimates for Michigan and Indiana were divided among the nearfield model areas because farfield area withdrawals generally were small.

- Irrigation estimates for the Upper Peninsula and Northern Lower Peninsula of Michigan do not include water withdrawals for agricultural uses.

- Irrigation estimates for the Southern Lower Peninsula include water withdrawals for golf course uses; water withdrawals for agricultural uses were estimated for only 11 counties.

- Totals among tables do not match because of differences in how model cells were divided among subregions and aquifer systems.

- Also, the overall total may be slightly different than the total by aquifer system due to rounding.

${ }^{a}$ The nearfield area extends beyond the Lake Michigan Basin divide, and this increase is from adjacent counties; data are from Southern Illinois University Carbondale (Dziegielewski, Benedykt, 2008).

${ }^{\mathrm{b}}$ The decrease is largely attributed to deindustrialization of the area; however, other reasons such as expanded service areas delivering surface water from Lake Michigan may contribute. This deindustrialization mostly ended during the last time model interval, and the model rate was adjusted based on obtained water-use records (appendix 6E; Wisconsin Department of Natural Resources, 2009).

${ }^{c}$ The decrease is largely attributed to reductions in water use that occurred in the Southern Lower Peninsula after the last model time interval.

${ }^{\mathrm{d}}$ The decrease is attributed mostly from increased urbanization and decreased land in agriculture (calculated from the land transformation model and Census of Agriculture sources listed in Appendix 6D).

'Value reported by the Southern Illinois University Carbondale (Dziegielewski, Benedykt, 2008). 


\section{Appendix 6C. Methods for estimating 2040 water use by category and state.}

[Methods for most of the Illinois study area were not needed because future projections were available from other sources; there were no 2040 miscellaneous water-use estimates for Michigan, Indiana, and Illinois; LMB, Lake Michigan Basin; gal/acre/d, gallons per acre per day]

\begin{tabular}{|c|c|c|c|}
\hline State(s) & Estimate & Equation & Comments \\
\hline \multicolumn{4}{|c|}{ Public supply } \\
\hline Wisconsin & $\begin{array}{l}2040 \\
\text { population }\end{array}$ & $\begin{array}{l}2030 \text { population }+(0.5 \times(2030 \\
\text { population }-2000 \\
\text { population }) \div 30 \text { years })\end{array}$ & $\begin{array}{l}\text { The average percentage change in population by community } \\
\text { for the } 30 \text {-year interval from } 2000 \text { to } 2030 \text { was calculated. } \\
\text { This value was then converted into the number of persons } \\
\text { to add or remove on an average annual basis. Half of this } \\
\text { rate was applied forward for } 10 \text { more years until } 2040 \text {. }\end{array}$ \\
\hline $\begin{array}{l}\text { Wisconsin, } \\
\text { Michigan, } \\
\text { and Indiana }\end{array}$ & 2040 water use & $\begin{array}{l}2040 \text { population } \times \text { percentage served } \\
\text { groundwater through public } \\
\text { supply } \times \text { county-specific } \\
\text { per capita use }\end{array}$ & $\begin{array}{l}\text { Percentage served groundwater through public supply } \\
\text { determined basis on } 2005 \text { data in Wisconsin, } 1998 \text { data in } \\
\text { Michigan, and } 1995 \text { data in Indiana; county per capita use } \\
\text { is based on } 2005 \text { values for all three States. }\end{array}$ \\
\hline \multicolumn{4}{|c|}{ Industrial } \\
\hline Michigan & 2040 water use & $\begin{array}{l}2004 \text { withdrawal } \times \text { the average } \\
\text { change in groundwater } \\
\text { withdrawals for 1997-2004 }\end{array}$ & $\begin{array}{l}\text { The average change in groundwater withdrawals by county } \\
\text { was determined for each annual interval from } 1997 \text { to } \\
\text { 2004. The average of these changes was applied to the } \\
2004 \text { withdrawal amount. }\end{array}$ \\
\hline Wisconsin & 2040 water use & $\begin{array}{l}2040 \text { irrigated acreage } \times \text { water }- \\
\text { application rate }\end{array}$ & $\begin{array}{l}\text { Approximate water application rates for each county were } \\
\text { based on the estimated withdrawals for the last time period } \\
\text { in the LMB model divided by the } 2002 \text { county USDA ir- } \\
\text { rigated acreage, and then assigned to one of five applica- } \\
\text { tion rate categories: (1) } 100-300=200 \mathrm{gal} / \mathrm{acre} / \mathrm{d} \text {; (2) } \\
301-500=400 \mathrm{gal} / \mathrm{acre} / \mathrm{d} \text {; (3) } 501-700=600 \mathrm{gal} / \mathrm{acre} / \mathrm{d} \text {; } \\
\text { (4) } 701-900=800 \mathrm{gal} / \mathrm{acre} / \mathrm{d} \text {; and (5) } 901 \text { or higher }= \\
1,000 \mathrm{gal} / \mathrm{acre} / \mathrm{d} \text {. }\end{array}$ \\
\hline
\end{tabular}


Appendix 6C. Methods for estimating 2040 water use by category and state.-Continued

[Methods for most of the Illinois study area were not needed because future projections were available from other sources; there were no 2040 miscellaneous water-use estimates for Michigan, Indiana, and Illinois; LMB, Lake Michigan Basin; gal/acre/d, gallons per acre per day]

\begin{tabular}{|c|c|c|c|}
\hline State(s) & Estimate & Equation & Comments \\
\hline Michigan & $\begin{array}{l}2040 \text { golf } \\
\text { course water } \\
\text { use }\end{array}$ & $\begin{array}{l}2004 \text { withdrawal } \times \text { average change } \\
\text { in groundwater withdrawals for } \\
\text { 1997-2004 }\end{array}$ & $\begin{array}{l}\text { The average change in groundwater withdrawals by county } \\
\text { was determined for each annual interval from } 1997 \text { to } \\
\text { 2004. The average of these changes was applied to the } \\
2004 \text { withdrawal amount. }\end{array}$ \\
\hline Indiana & 2040 water use & $\begin{array}{l}2001-5 \text { withdrawals } \times \text { the average } \\
\text { change in number of farms with } \\
\text { irrigated cropland for } 1978-2002\end{array}$ & $\begin{array}{l}\text { The average change in the number of farms with irrigated } \\
\text { cropland, by county, was determined for each annual } \\
\text { interval from } 1978 \text { to } 2002 \text {. The average of these changes } \\
\text { was applied to the withdrawal amount from the last time } \\
\text { interval in the LMB model. }\end{array}$ \\
\hline $\begin{array}{l}\text { Illinois (farfield } \\
\text { model area } \\
\text { only) }\end{array}$ & 2040 water use & $\begin{array}{l}\text { Base irrigated acreage } \times \text { water } \\
\text { application rate } \times 40 \text {-year rate of } \\
\text { population change }\end{array}$ & $\begin{array}{l}\text { A statewide average groundwater-application rate of } 536 \mathrm{gal} / \\
\text { acre/d was calculated for Illinois from the Farm and Ranch } \\
\text { Irrigation Survey (U.S. Department of Agriculture, 2004b, } \\
\text { listed in appendix } 6 D \text { ]. The } 40 \text {-year rate of population } \\
\text { change was used to increase an underestimated water use } \\
\text { in the model. Population growth is not commonly used to } \\
\text { calculate future agricultural and golf course irrigation uses. }\end{array}$ \\
\hline \multicolumn{4}{|c|}{ Miscellaneous } \\
\hline Wisconsin & 2040 water use & $\begin{array}{l}2001-5 \text { withdrawals by aquifer } \\
\text { system } \times \text { annual rate of change } \\
\times 35 \text { years }\end{array}$ & $\begin{array}{l}\text { Calculated annual rate of change during } 1985-2005 \text { (last } 3 \\
\text { time intervals in LMB model) and projected rate forward } \\
\text { to } 2040 \text { (for } 35 \text { years). }\end{array}$ \\
\hline
\end{tabular}


Appendix 6D. References used in the estimation of 2040 water use, by state.

\begin{tabular}{|c|c|c|c|}
\hline Reference & Data theme & Scale & $\begin{array}{l}\text { Categories or } \\
\text { report location } \\
\text { in which used }\end{array}$ \\
\hline \multicolumn{4}{|l|}{ Multiple states } \\
\hline $\begin{array}{l}\text { Heimlich, Ralph, 2003, Agricultural resources and environmental indicators, } \\
\text { 2003: Agriculture Handbook No. AH722, released February 2003, } \\
\text { chap. 2, sec. 1-Water use and pricing, accessed October 1, 2009, at } \\
\text { http://www.ers.usda.gov/publications/arei/ah722/. }\end{array}$ & $\begin{array}{l}\text { Water-application } \\
\text { rates, regional } \\
\text { trends in } \\
\text { irrigation }\end{array}$ & National & Irrigation \\
\hline $\begin{array}{l}\text { Hutson, S.S., Barber, N.L., Kenny, J.J., Linsey, K.S., Lumia, D.S., and } \\
\text { Maupin, M.A., 2004, Estimated use of water in the United States in 2000: } \\
\text { U.S. Geological Survey Circular 1268, } 46 \text { p. }\end{array}$ & $\begin{array}{l}\text { Water-use } \\
\text { estimation }\end{array}$ & National & $\begin{array}{l}\text { Used in appendix } \\
6 A \text { text }\end{array}$ \\
\hline $\begin{array}{l}\text { Thompson, S.A., 1999, Water use, management, and planning in the United } \\
\text { States: Academic Press, chap } 6 .\end{array}$ & $\begin{array}{l}\text { Water demand } \\
\text { and supply- } \\
\text { management } \\
\text { and planning }\end{array}$ & National & $\begin{array}{l}\text { Used in appendix } \\
6 A \text { text }\end{array}$ \\
\hline $\begin{array}{l}\text { U.S. Geological Survey, 2009, Water use in the United States, accessed June } \\
\text { 23, 2009, at http://water.usgs.gov/watuse/. }\end{array}$ & $\begin{array}{l}\text { Aggregated } \\
\text { Water-Use Data } \\
\text { System data } \\
\text { for } 1985,1990, \\
1995 \text {, and } 2000\end{array}$ & $\begin{array}{l}\text { County (Wiscon- } \\
\text { sin, Michigan, } \\
\text { and Indiana) }\end{array}$ & $\begin{array}{l}\text { Industrial, irriga- } \\
\text { tion }\end{array}$ \\
\hline $\begin{array}{l}\text { Central Brown County Water Authority, 2007, Who we are, accessed May } \\
\text { 23, 2008, at http://www.cbcwaterauthority.com/. }\end{array}$ & $\begin{array}{l}\text { Communities that } \\
\text { changed water } \\
\text { source from } \\
\text { groundwater to } \\
\text { surface water } \\
\text { after } 2005\end{array}$ & $\begin{array}{l}\text { Community } \\
\text { (Northeastern } \\
\text { Wisconsin) }\end{array}$ & Public supply \\
\hline $\begin{array}{l}\text { City of Green Bay, 2009, Green Bay Water Utility, accessed July 2, 2009, at } \\
\text { http://www.ci.green-bay.wi.us/water/index.html. }\end{array}$ & $\begin{array}{l}\text { Communities } \\
\text { that have } \\
\text { changed water } \\
\text { source from } \\
\text { groundwater to } \\
\text { surface water } \\
\text { after } 2005\end{array}$ & $\begin{array}{l}\text { Community } \\
\text { (Northeastern } \\
\text { Wisconsin) }\end{array}$ & Public supply \\
\hline
\end{tabular}


Appendix 6D. References used in the estimation of 2040 water use, by state.-Continued

Reference
Wisconsin_Conti
Cobb, Kathy, 1998, Wisconsin's fish farms grow to meet product demand:
Wisconsin State Roundup, July 1998, accessed March 13, 2009, at http://
www.minneapolisfed.org/publications_papers/pub_display.cfm?id=2534.
Southeastern Wisconsin Regional Planning Commission, 2004, The econo-
my of Southeastern Wisconsin: Technical report number 10, 4th ed., re-
leased July 2004, 784 p., accessed October 1, 2009, at http://www.sewrpc.
org/publications/techrep/tr-010_economy_southeastern_wisconsin.pdf.
Southeastern Wisconsin Regional Planning Commission, 2008, A Regional
water supply plan for Southeastern Wisconsin_Chapter III, Existing
water supply conditions in the region: SEWRPC Planning Report No.
52, Preliminary Draft, 115 p., accessed October 1,2009, at http://www.
sewrpc.org/watersupplystudy/pdfs/pr-052_chapter-03_preliminary_draft.
pdf.

U.S. Department of Agriculture, 1955, Irrigation-Water management guide for Wisconsin - tentative, for the design of sprinkler irrigation systems: Madison, Wis., Soil Conservation Service, 12 p.

U.S. Department of Agriculture-National Agricultural Statistics Service, 2004, 2002 Census of Agriculture - Volume 1, Geographic area seriesPart 49, Wisconsin - Chapter 2, County level data, accessed October 1, 2009, at http://www.agcensus.usda.gov/Publications/2002/Volume_1, Chapter_2_County_Level/Wisconsin/index.asp.

U.S. Department of Agriculture-National Agricultural Statistics Service, 2009, 2007 Census of Agriculture - Volume 1, Geographic area seriesPart 49, Wisconsin - Chapter 2, County level data, accessed October 1, 2009, at http://www.agcensus.usda.gov/Publications/2007/Full_Report/ Volume_1,_Chapter_2_County_Level/Wisconsin/index.asp.

Wisconsin Department of Administration, 2006, Population projections data-MCD and municipal (MCD's crossing county lines combined) population projections, 2000-2030, accessed March 13, 2009, at http:// www.doa.state.wi.us/subcategory.asp? linksubcatid $=105 \&$ linkcatid $=11 \& l$ inkid $=64$ \&locid $=9$.

Wisconsin Department of Natural Resources, 2009, Groundwater Retrieval Network and High Capacity Well database: Bureau of Drinking Water and Groundwater, accessed June 1, 2009, at http://prodoasext.dnr.wi.gov/ inter1/hicap\$.startup.

Wisconsin Department of Workforce Development, 2009, Regional employment projections - Long-term projections, 2006-2016: Office of Economic Advisors, accessed March 4, 2009 at http://dwd.wisconsin.gov/oea/ employment_projections/employment_projections.htm.

\footnotetext{
Michigan

Michigan Department of Energy, Labor, \& Economic Growth-Labor Market Information, 2004, Industry forecasts, 2004-2014, accessed March 25, 2009, at http://www.milmi.org/?PAGEID $=67 \& S U B I D=177$.

Michigan Department of Environmental Quality, 2009, Water withdrawal reports, data and graphics, accessed March 11, 2009, at http://www. michigan.gov/deq/0,1607,7-135-3313_3684_45331-72931--,00.html.
}

Data theme Scale $\quad \begin{gathered}\text { Categories or } \\ \text { report location } \\ \text { in which used }\end{gathered}$

Aquacultural

trend

Regional economic projection by employment industry

Estimated withdrawals of existing watersupply systems

Principal factors for controlling the amount of irrigation

Table 10. Irrigation: 2002 and 1997

Table 10 Irrigation: 2007 and 2002

Community population projections, 2000-2030

Reported groundwater withdrawals for 2007

\section{Employment forecasts}

State

Community (Southeastern Wisconsin)

Community (Southeastern Wisconsin)

State

Irrigation

County

Irrigation

Miscellaneous

Industrial

Public supply

.

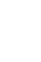


Appendix 6D. References used in the estimation of 2040 water use, by state.-Continued

\begin{tabular}{|c|c|c|c|}
\hline Reference & Data theme & Scale & $\begin{array}{l}\text { Categories or } \\
\text { report location } \\
\text { in which used }\end{array}$ \\
\hline \multicolumn{4}{|c|}{ Michigan-Continued } \\
\hline $\begin{array}{l}\text { Office of the State Demographer-Michigan Information Center, 1996, } \\
\text { Preliminary population projections to the year } 2020 \text { for Michigan by } \\
\text { counties, accessed October 31, 2008, at http://www.michigan.gov/ } \\
\text { documents/8510_26104_7.pdf. }\end{array}$ & $\begin{array}{l}\text { Populations and } \\
\text { projections for } \\
1970-2020\end{array}$ & County & Public supply \\
\hline $\begin{array}{l}\text { Tri-County Regional Planning Commission, 2008, Socio-economic fore- } \\
\text { casts, adopted June 2008, accessed February 18, 2009, at http://www. } \\
\text { tri-co.org/SE_Forecast\%20June\%202008\%20(Final).html. }\end{array}$ & $\begin{array}{l}\text { Populations and } \\
\text { projections for } \\
2005-2045\end{array}$ & $\begin{array}{l}\text { County (Clinton, } \\
\text { Eaton, and } \\
\text { Ingham) }\end{array}$ & Public supply \\
\hline $\begin{array}{l}\text { U.S. Census Bureau, 2009, Selected historical decennial census population } \\
\text { and housing counts, accessed March 10, 2009, at http://www.census.gov/ } \\
\text { population/www/censusdata/hiscendata.html. }\end{array}$ & $\begin{array}{c}\text { Populations for } \\
1970-2000\end{array}$ & County & Public supply \\
\hline $\begin{array}{l}\text { U.S. Department of Agriculture-National Agricultural Statistics Ser- } \\
\text { vice, 1992a, } 1992 \text { Census of agriculture-State and county highlights, } \\
\text { Michigan, accessed October 1, 2009, at http://www.agcensus.usda.gov/ } \\
\text { Publications/1992/State_and_County_Highlights/Michigan/index.asp. }\end{array}$ & $\begin{array}{l}\text { Irrigated acres } \\
\text { and number of } \\
\text { farms for } 1992\end{array}$ & County & Irrigation \\
\hline $\begin{array}{l}\text { U.S. Department of Agriculture-National Agricultural Statistics Ser- } \\
\text { vice, 1994, } 1992 \text { Census of agriculture-Farm and ranch irrigation } \\
\text { survey (1994)-Table 2, Irrigated farms by acres irrigatied, } 1994 \text { and } \\
\text { 1988, accessed March 11, 2009, at http://www.agcensus.usda.gov/ } \\
\text { Publications/1992/Farm_and_Ranch_Irrigation_Survey/table2.pdf. }\end{array}$ & $\begin{array}{l}\text { Irrigated acres } \\
\text { and number of } \\
\text { farms for } 1994 \\
\text { and } 1998\end{array}$ & County & Irrigation \\
\hline $\begin{array}{l}\text { U.S. Department of Agriculture-National Agricultural Statistics Service, } \\
\text { 1997, } 1997 \text { Census of agriculture_County data_-Table 8, Irrigation, } \\
\text { 1997 and 1992, accessed March 11, 2009, at http://www.agcensus.usda. } \\
\text { gov/Publications/1997/Vol_1_Chapter_2_County_Tables/Michigan/ } \\
\text { mi2_08.pdf. }\end{array}$ & $\begin{array}{l}\text { Irrigated acres } \\
\text { and number of } \\
\text { farms for } 1997 \\
\text { and } 1992\end{array}$ & County & Irrigation \\
\hline $\begin{array}{l}\text { U.S. Department of Agriculture-National Agricultural Statistics Service, } \\
\text { 2002, } 2002 \text { Census of agriculture_CCounty data_-Table 10, Irrigation, } \\
2002 \text { and 1997, accessed March 11, 2009, at http://www.agcensus.usda. } \\
\text { gov/Publications/2002/Volume_1,_Chapter_2_County_Level/Michigan/ }\end{array}$ & $\begin{array}{l}\text { Irrigated acres } \\
\text { and number of } \\
\text { farms for } 2002 \\
\text { and } 1997\end{array}$ & County & Irrigation \\
\hline
\end{tabular}


Appendix 6D. References used in the estimation of 2040 water use, by state.-Continued

\begin{tabular}{|c|c|c|c|}
\hline Reference & Data theme & Scale & $\begin{array}{l}\text { Categories or } \\
\text { report location } \\
\text { in which used }\end{array}$ \\
\hline \multicolumn{4}{|c|}{ Michigan-Continued } \\
\hline $\begin{array}{l}\text { U.S. Department of Agriculture-National Agricultural Statistics Service, } \\
\text { 2007, } 2007 \text { Census of agriculture_County data-Table 10, Irrigation, } \\
2007 \text { and 2002, accessed March 11, 2009, at http://www.agcensus.usda. } \\
\text { gov/Publications/2007/Full_Report/Volume_1,_Chapter_2_County_Level/ } \\
\text { Michigan/st26_2_010_010.pdf. }\end{array}$ & $\begin{array}{l}\text { Irrigated acres } \\
\text { and number of } \\
\text { farms for } 2007 \\
\text { and } 2002\end{array}$ & County & Irrigation \\
\hline $\begin{array}{l}\text { West Michigan Regional Planning Commission, 2009, Population data, ac- } \\
\text { cessed June 23, 2009, at http://wmrpc.org/population_data.htm. }\end{array}$ & $\begin{array}{l}\text { Population } \\
\text { projections for } \\
2010,2015, \\
\text { and } 2020\end{array}$ & $\begin{array}{l}\text { County } \\
\text { (Allegan, Ionia, } \\
\text { Kent, Mecosta, } \\
\text { Montcalm, } \\
\text { Osceola, and } \\
\text { Ottawa) }\end{array}$ & Public supply \\
\hline
\end{tabular}

Indiana Business Research Center-Indiana University's Kelley School of

Indiana Business Research Center-Indiana University's Kelley School of Business, 2009, STATS Indiana—Population projections, accessed June 23, 2009, at http://www.stats.indiana.edu/topic/projections.asp.

Indiana Department of Workforce Development, 2009, County highlights, accessed June 23, 2009, at http://www.hoosierdata.in.gov/highlights/ default.asp.

Indiana University-Center for Econometric Model Research, 2009, Longrange projections, accessed June 9, 2009, at http://www.iu.edu/ cemr/ current_summaries/long_range.html.

U.S. Census Bureau, 2009, Selected historical decennial census population and housing counts, accessed March 10, 2009, at http://www.census.gov/ population/www/censusdata/hiscendata.html.

U.S. Department of Agriculture-National Agricultural Statistics Service, 1992a, 1992 Census of agriculture, State and county highlights, Indiana, accessed March 9, 2009, at http://www.agcensus.usda.gov/ Publications/1992/State_and_County_Highlights/Indiana/index.asp.

U.S. Department of Agriculture-National Agricultural Statistics Service, 1992b, 1992 Census of agriculture - County data-Table 8, Irrigation, 1992 and 1987, accessed March 11, 2009, at http://www.agcensus.usda. gov/Publications/1992/Volume_1_Chapter_2_County_Tables/Indiana/ in2_08.pdf.

U.S. Department of Agriculture-National Agricultural Statistics Service, 1997, 1997 Census of agriculture - County data - Table 8, Irrigation, 1997 and 1992, accessed March 11, 2009, at http://www.agcensus.usda. gov/Publications/1997/Vol_1_Chapter_2_County_Tables/Indiana/in2_08. pdf.

U.S. Department of Agriculture-National Agricultural Statistics Service, 2002, 2002 Census of agriculture - County data-Table 10, Irrigation, 2002 and 1997, accessed March 11, 2009, at http://www.agcensus.usda. gov/Publications/2002/Volume_1,_Chapter_2_County_Level/Indiana/ st18_2_010_010.pdf.

U.S. Department of Agriculture-National Agricultural Statistics Service, 2007, 2007 Census of agriculture - County data-Table 10, Irrigation, 2007 and 2002, accessed March 11, 2009, at http://www.agcensus.usda. gov/Publications/2007/Full_Report/Volume_1,_Chapter_2_County_Level/ Indiana/st18_2_010_010.p $\overline{d f}$.

\begin{tabular}{|c|c|c|}
\hline $\begin{array}{l}\text { Population } \\
\text { projections for } \\
2040\end{array}$ & County & Public sup \\
\hline $\begin{array}{l}\text { Population } \\
\text { projections for } \\
2010,2015, \\
2020 \text {, and } 2025\end{array}$ & County & Public sup \\
\hline $\begin{array}{l}\text { Employment } \\
\text { projections } \\
(2012-29)\end{array}$ & State & Industrial \\
\hline $\begin{array}{c}\text { Populations for } \\
1970-2000\end{array}$ & County & Public sup \\
\hline $\begin{array}{l}\text { Irrigated acres } \\
\text { and number of } \\
\text { farms for } 1992\end{array}$ & County & Irrigation \\
\hline $\begin{array}{l}\text { Irrigated acres } \\
\text { and number of } \\
\text { farms for } 1992 \\
\text { and } 1987\end{array}$ & County & Irrigation \\
\hline
\end{tabular}

Irrigated acres and number of farms for 1997 and 1992

Irrigated acres and number of farms for 2002 and 1997

Irrigated acres and number of County Irrigation farms for 2007 and 2002 
Appendix 6D. References used in the estimation of 2040 water use, by state.-Continued

\begin{tabular}{|c|c|c|c|}
\hline Reference & Data theme & Scale & $\begin{array}{l}\text { Categories or } \\
\text { report location } \\
\text { in which used }\end{array}$ \\
\hline \multicolumn{4}{|l|}{ Illinois } \\
\hline $\begin{array}{l}\text { Dziegielewski, Benedykt, 2008, Regional water demand scenarios for } \\
\text { Northeastern Illinois, 2005-2050-Project completion report, June 15, } \\
2008 \text { (modified June 27, 2008): Southern Illinois University Carbondale, } \\
\text { Department of Geography and Environmental Resources, } 218 \text { p., accessed } \\
\text { October 1, 2009, at http://www.cmap.illinois.gov/WorkArea/showcontent. } \\
\text { aspx?id=9040. }\end{array}$ & $\begin{array}{l}\text { Water-use esti- } \\
\text { mates for } 2040\end{array}$ & $\begin{array}{l}\text { County } \\
\text { (Northeastern } \\
\text { Illinois) }\end{array}$ & $\begin{array}{l}\text { Public supply, } \\
\text { industrial, and } \\
\text { irrigation }\end{array}$ \\
\hline $\begin{array}{l}\text { Illinois Department of Commerce and Economic Opportunity, 2009, Popula- } \\
\text { tion projections, accessed October 1, 2009, at http://www.commerce.state. } \\
\text { il.us/dceo/Bureaus/Facts_Figures/Population_Projections/. }\end{array}$ & $\begin{array}{l}\text { Population } \\
\text { projections for } \\
2010,2015 \\
2020,2025 \\
\text { and } 2030\end{array}$ & County & Irrigation \\
\hline $\begin{array}{l}\text { Southern Illinois University Carbondale, 2005, County-level forecasts of } \\
\text { water use in Illinois, 2005-2025_-Project completion report, January } \\
2005 \text { (revised March 30, 2005): Carbondale, Ill., Department of Georg- } \\
\text { raphy, } 211 \text { p., accessed October 1, 2009, at http://info.geography.siu.edu/ } \\
\text { geography_info/research/documents/ISWS_IL_Water_Use_Projections. } \\
\text { pdf. }\end{array}$ & $\begin{array}{l}\text { Water-use esti- } \\
\text { mates for } 2025\end{array}$ & County & $\begin{array}{l}\text { Public supply, } \\
\text { industrial, and } \\
\text { irrigation }\end{array}$ \\
\hline $\begin{array}{l}\text { U.S. Bureau of Labor Statistics, 2009, Economy at a glance-Illinois, Met- } \\
\text { ropolitan area data, accessed November 20, 2009, at http://www.bls.gov/ } \\
\text { eag/eag.il.htm. }\end{array}$ & $\begin{array}{l}\text { Employment data } \\
\text { by sector since } \\
1990\end{array}$ & $\begin{array}{l}\text { State and metro- } \\
\text { politan area }\end{array}$ & Industrial \\
\hline $\begin{array}{l}\text { U.S. Department of Agriculture-National Agricultural Statistics Service, } \\
\text { 2009, 2007 Census of agriculture_-Volume 1, Geographic area series- } \\
\text { Part 13, Illinois_Chapter 2, County level data, accessed October 1, } \\
\text { 2009, at http://www.agcensus.usda.gov/Publications/2007/Full_Report/ } \\
\text { Volume_1,_Chapter_2_County_Level/Illinois/index.asp. }\end{array}$ & $\begin{array}{l}\text { Irrigated acres } \\
\text { and number of } \\
\text { farms for } 2007 \\
\text { and } 2002\end{array}$ & County & Irrigation \\
\hline $\begin{array}{l}\text { U.S. Geological Survey, 2009, Water use in the United States, accessed } \\
\text { October 1, 2009, at http://water.usgs.gov/watuse/. }\end{array}$ & $\begin{array}{l}\text { Groundwater-use } \\
\text { estimates for } \\
1995 \text { and } 2000\end{array}$ & County & $\begin{array}{l}\text { Industrial, } \\
\text { irrigation }\end{array}$ \\
\hline
\end{tabular}




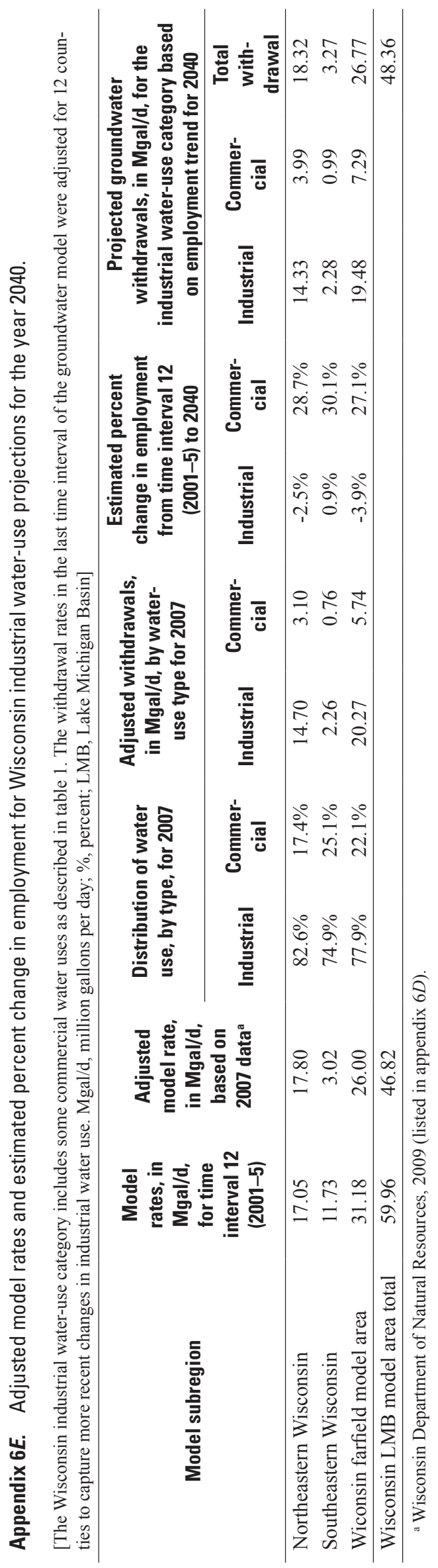


